US Army Corps

of Engineers 。

Prepared for the U.S. Army Corps of Engineers, Portland District,

under an Interagency Agreement with the U.S. Department of Energy

Contract DE-AC05-76RL01830

\title{
Migratory Behavior and Survival of Juvenile Salmonids in the Lower Columbia River and Estuary in 2009
}

Final Report
GA McMichael
KD Ham
RA Harnish
PS Titzler
BJ Bellgraph
MS Hughes
JA Carter

August 2010

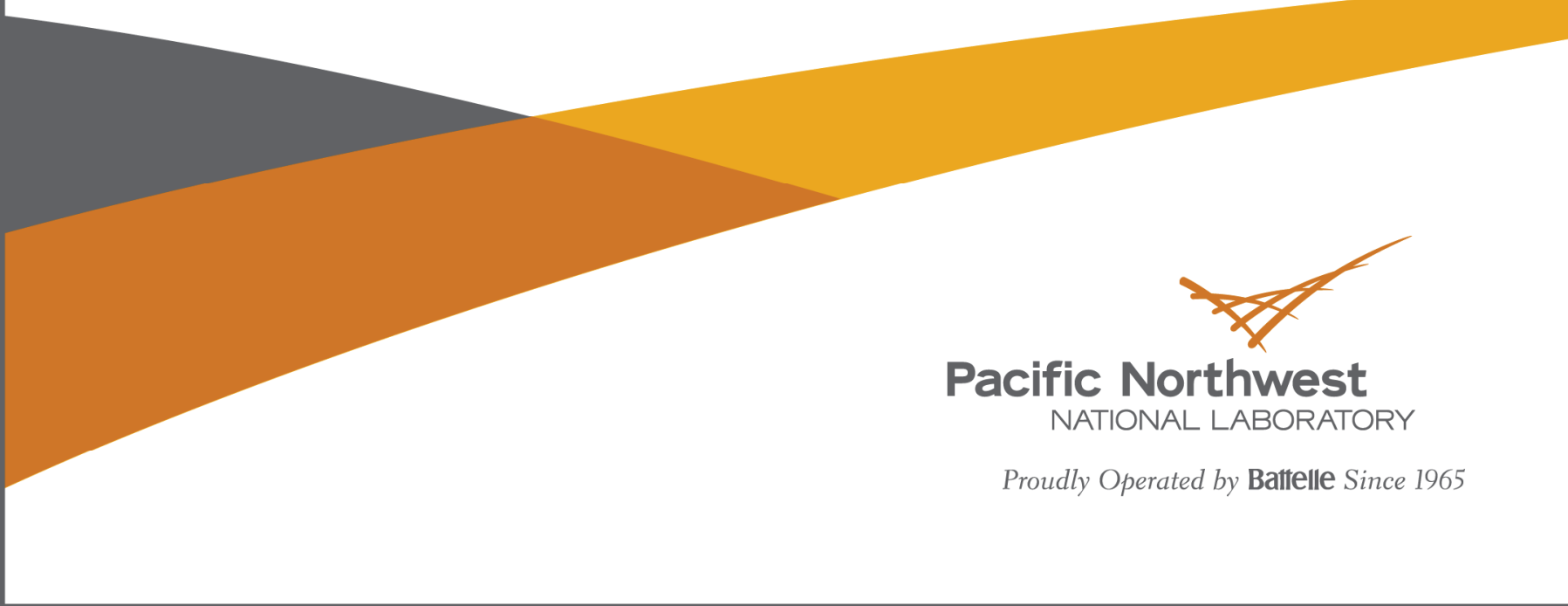




\section{DISCLAIMER}

This report was prepared as an account of work sponsored by an agency of the United States Government. Neither the United States Government nor any agency thereof, nor Battelle Memorial Institute, nor any of their employees, makes any warranty, express or implied, or assumes any legal liability or responsibility for the accuracy, completeness, or usefulness of any information, apparatus, product, or process disclosed, or represents that its use would not infringe privately owned rights. Reference herein to any specific commercial product, process, or service by trade name, trademark, manufacturer, or otherwise does not necessarily constitute or imply its endorsement, recommendation, or favoring by the United States Government or any agency thereof, or Battelle Memorial Institute. The views and opinions of authors expressed herein do not necessarily state or reflect those of the United States Government or any agency thereof.

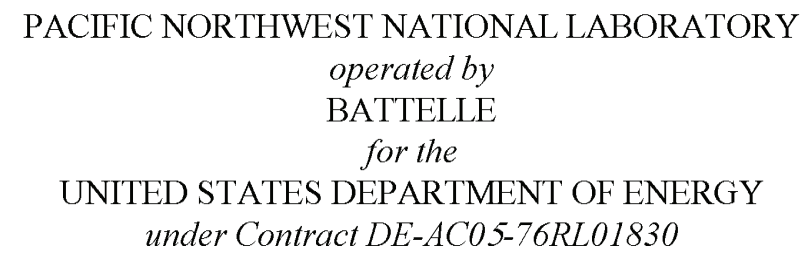

Printed in the United States of America

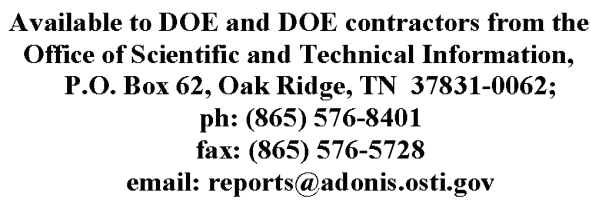

Available to the public from the National Technical Information Service, U.S. Department of Commerce, 5285 Port Royal Rd., Springfield, VA 22161 ph: (800) 553-6847 fax: $(703) 605-6900$ email: orders@ntis.fedworld.gov online ordering: http://www.ntis.gov/ordering.htm

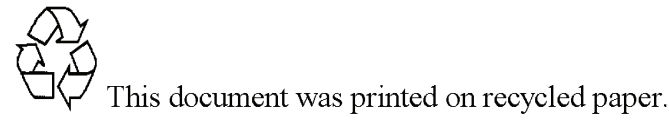




\section{Migratory Behavior and Survival of Juvenile Salmonids in the Lower Columbia River Estuary in $\mathbf{2 0 0 9}$}

\section{Final Report}

$\begin{array}{ll}\text { GA McMichael } & \text { KD Ham } \\ \text { RA Harnish } & \text { PS Titzler } \\ \text { BJ Bellgraph } & \text { MS Hughes } \\ \text { JA Carter } & \end{array}$

August 2010

Prepared for

the U.S. Army Corps of Engineers, Portland District under an Interagency Agreement with the U.S. Department of Energy Contract DE-AC05-76RL01830

Pacific Northwest National Laboratory

Richland, Washington 99352 
This report should be cited as:

McMichael, G. A., R. A. Harnish, B. J. Bellgraph, J. A. Carter, K. D. Ham, P. S. Titzler, and M. S. Hughes. 2010. Survival and Migratory Behavior of Juvenile Salmonids in the Lower Columbia River Estuary in 2009. PNNL-19545, Pacific Northwest National Laboratory, Richland, Washington. 


\section{Preface}

The study reported herein was funded as part of the Anadromous Fish Evaluation Program, which is managed by the U.S. Army Corps of Engineers (USACE). The Anadromous Fish Evaluation Program study code is EST-P-02-01: A Study of Salmonid Survival and Behavior through the Columbia River Estuary Using Acoustic Tags. The study was conducted by the Pacific Northwest National Laboratory (PNNL) and NOAA Fisheries for the USACE Portland District. The USACE technical lead was Blaine Ebberts. The PNNL study project manager was Geoff McMichael (509-371-7162). The data are archived at PNNL offices in Richland, Washington. NOAA Fisheries will report separately on its mobile telemetry efforts. 



\section{Executive Summary}

The U.S. Army Corps of Engineers (USACE) Portland District places a high priority on increasing the understanding of the migratory behavior and survival of juvenile salmonids emigrating through the lower $235 \mathrm{~km}$ of the Columbia River and estuary. This understanding is critical to determining the effects of the Federal Columbia River Power System (FCRPS) on the 'post-hydrosystem' performance of these populations. Increased survival rates through the FCRPS and through the estuary are necessary to meet recovery goals set forth in the 2008 Biological Opinion (BiOp) on FCRPS operations. The goal of the study reported herein is to provide information regarding the migratory behavior and survival data from juvenile salmonids passing through the lower Columbia River and estuary between Bonneville Dam and the Pacific Ocean. The study was conducted by the Pacific Northwest National Laboratory using the Juvenile Salmon Acoustic Telemetry System (JSATS). The Portland District of the USACE and regional fisheries managers will use the information to manage the configuration and operation of the FCRPS and to evaluate management actions such as estuary habitat restoration and avian predation management to maximize survival rates of juvenile salmonids.

\section{Objectives}

In this report we present estimated survival of acoustic-tagged juvenile yearling Chinook salmon (CH1), steelhead (STH), and subyearling Chinook salmon (CH0) downstream of Bonneville Dam as they migrated seaward through the Columbia River and its estuary. This study also provides, for the first time, estimates of survival through the lower $192 \mathrm{~km}$ of the Columbia River and estuary for groups of fish with known passage routes at John Day and Bonneville dams. The primary objective of this study was to estimate the survival of yearling and subyearling Chinook salmon and steelhead through multiple reaches of the Columbia River between Bonneville Dam and the Pacific Ocean. Other objectives were to, 1) compare the effects of FCPRS passage history on mortality of juvenile salmonids in the lower $192 \mathrm{~km}$ of the Columbia River and estuary, and 2) monitor and map migration pathway and habitat associations and behaviors relative to these pathways to support habitat restoration activities.

\section{Methods}

This study took advantage of JSATS-tagged fish collected and tagged at John Day Dam and released into the reservoir $41 \mathrm{~km}$ upstream of John Day Dam (near Roosevelt, WA at river kilometer (rkm) 388) during the spring and summer of 2009 for another Portland District project; "Studies of Surface Spill at John Day Dam" study (SPE-P-08-03). All study fish were double tagged with a $0.43 \mathrm{~g}$ JSATS acoustic transmitter and a passive integrated transponder (PIT) tag. Tagged yearling Chinook salmon $(\mathrm{N}=3470)$ and steelhead $(\mathrm{N}=3471)$ were released between 27 April and 26 May 2009. Subyearling Chinook salmon $(\mathrm{N}=3461)$ were released between 16 June and 15 July 2009.

The study area included the Columbia River and estuary between Bonneville Dam (rkm 235) and the mouth of the Columbia River ( $\mathrm{rkm} 2.8$ ). Autonomous acoustic receivers were deployed at 104 locations between the forebay of Bonneville Dam (rkm 236) and rkm 2.8 between 27 April and 17 August 2009. Receivers were recovered, tested, and redeployed every 28 days to recover data and replace batteries. Receivers were primarily deployed in lines that ran perpendicular to shore, referred to as arrays, with receivers spaced about 100-200 m apart. Receiver arrays were deployed across the entire river channel in the forebay of Bonneville Dam ( $\mathrm{rkm} 236$ ), at Lady ( rkm 192) and Cottonwood (rkm 113.0) islands, at 
Oak Point (rkm 86.2), and at two locations near the mouth of the river at East Sand Island (rkm 8.3) and the Columbia River Bar (rkm 2.8). Partial arrays were deployed across the primary channel at Three Tree Point (rkm 49.6), Harrington Point ( $r k m$ 37.3), and at the Astoria Bridge (rkm 22.0). In addition to these arrays, three single receivers were deployed in Grays Bay ( $\mathrm{rkm} 34.0$ and 29.3) to provide information about the use of off-channel areas by emigrating smolts.

Detections of JSATS-tagged fish on cabled receivers on John Day and Bonneville dams were used to assign passage routes to individual fish at these dams. These route assignments were then used to group fish for analyses of effects of passage route on estimated survival through the lower $192 \mathrm{~km}$ of the Columbia River and estuary. The Cormack-Jolly-Seber (CJS) (Single-Release (SR)) survival model was used to estimate survival based on detection histories of the JSATS-tagged fish.

To examine migratory behavior, detections of study fish were used to determine travel time, migration pathways through the lower $37 \mathrm{~km}$, cross-channel distribution, diel movement patterns, and tidal influence on movements. PIT tags recovered by NOAA Fisheries crews on bird colonies in the estuary were used to examine relationships between fish movement patterns and avian predation rates.

\section{Results}

\section{JSATS Performance}

JSATS transmitters in the tag life study lasted a minimum of 23 days. Over $99.5 \%$ of the study fish that were detected at the mouth of Columbia River were detected within 23 days of when their acoustic tags were activated.

Detection probabilities of acoustic transmitters on autonomous receiver arrays was generally high $(>90 \%)$ and independent of river discharge, with the exception of arrays at Lady Island (rkm 192), Three Tree Point (rkm 49.6), and Harrington Point (rkm 37.3). At Lady Island (rkm 192), detection probability was lower at higher river discharges. At Three Tree Point (rkm 49.6) and Harrington Point ( $\mathrm{rkm} 37.3)$, where the estuary is very wide $(\sim 10 \mathrm{~km})$, detection probabilities were relatively low $(\leq 57 \%)$ because receivers were only located near the primary river channel. Therefore, tagged fish migrating outside the primary channel were not likely to be detected at these two arrays.

Results of Burnham tests showed that upstream detections did not affect downstream detections and/or survival at most arrays. With the exception of some of the survival estimates at Three Tree Point (rkm 49.6) and Harrington Point ( $\mathrm{rkm} 37.3)$, most ( $>92 \%$ ) reach survival estimates indicated no violation of survival model assumptions relating to the influence of upstream detections on downstream detections and/or survival based on the Burnham test results.

\section{Survival Estimates}

The survival of yearling Chinook salmon smolts was generally high $(>0.90)$ between Bonneville Dam and Three Tree Point (rkm 49.6) and decreased substantially in the lower $50 \mathrm{~km}$ of the Columbia River estuary in 2009. The probability of survival for yearling Chinook salmon from the Bonneville Dam forebay ( $\mathrm{rkm} 236)$ to the mouth of the Columbia River ( $\mathrm{rkm} \mathrm{8.3)} \mathrm{varied} \mathrm{temporally} \mathrm{from} 0.74(\mathrm{SE}=0.02)$ to 0.85 (0.03) for the virtual release groups between 30 April and 2 June 2009 (Table ES1). The pooled survival probability estimate for all yearling Chinook salmon from rkm 236 to $\mathrm{rkm} 8.3$ was 0.78 (0.01). 
The survival of steelhead smolts in 2009 was generally low relative to yearling Chinook salmon through the lower $235 \mathrm{~km}$ of the Columbia River and estuary. Estimated survival probability of steelhead was over 0.90 between Bonneville Dam and Oak Point (rkm 86.2) and decreased sharply in the lower $86 \mathrm{~km}$ of the Columbia River estuary. The probability of survival for steelhead smolts from the Bonneville Dam forebay (rkm 236) to the mouth of the Columbia River (CR008.3) in 2009 varied temporally from $0.47(\mathrm{SE}=0.02)$ to $0.60(0.03)$ for the virtual release groups (Table ES2). The pooled survival probability estimate for all steelhead smolts from rkm 236 to rkm 8.3 was $0.53(0.01)$.

Survival probability for subyearling Chinook salmon in 2009 from the Bonneville Dam forebay (rkm 236) to the mouth of the river ( $\mathrm{rkm} 8.3$ ) ranged from $0.78(0.03)$ to $0.36(0.04)$, declining for each successive virtual release group as the season progressed (Table ES3). Pooled survival for all subyearling Chinook salmon between rkm 236 and rkm 8.3 was 0.64 (0.01). Mortality of subyearling Chinook salmon was more evenly distributed throughout the lower Columbia River and estuary than observed for yearling Chinook salmon and steelhead.

\section{Survival by Dam Passage Routes}

Route assignment at all passage routes for juvenile salmonid passage at John Day Dam and the Second Powerhouse portion of Bonneville Dam allowed us to begin to investigate the influence of FCRPS passage experience, albeit through only a small portion of the FCRPS at this point, on survival through the lower Columbia River and estuary. However, these results should be used with caution. Because it was not the primary objective of this study to assess latent mortality by passage history, insufficient sample sizes existed for many groups of fish sharing the same passage history, resulting in survival estimates with relatively large error bounds.

Possibly due to the low sample sizes and large error bounds, survival estimates did not differ significantly between any of the possible route combinations for yearling or subyearling Chinook salmon. However, significant differences in survival of steelhead passing through different passage routes were observed. The passage route combination that resulted in the highest survival of steelhead from Lady Island (rkm192) to the mouth of the Columbia River (rkm 8.3) was through the deep spill route at John Day Dam and through the corner collector at Bonneville Dam (0.70 [SE = 0.05], N = 137). Steelhead that passed through the deep spillway route at John Day Dam followed by passage through the corner collector at Bonneville Dam had a significantly higher probability of surviving from CR192.0 to CR008.3 than steelhead, with the following detection histories: JBS at John Day Dam and corner collector at Bonneville Dam (0.45 [SE = 0.05]); TSW at John Day Dam and corner collector at Bonneville Dam 0.56 $[\mathrm{SE}=0.03])$; and JBS at both John Day and Bonneville dams $(0.42[\mathrm{SE}=0.10])$. 


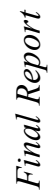

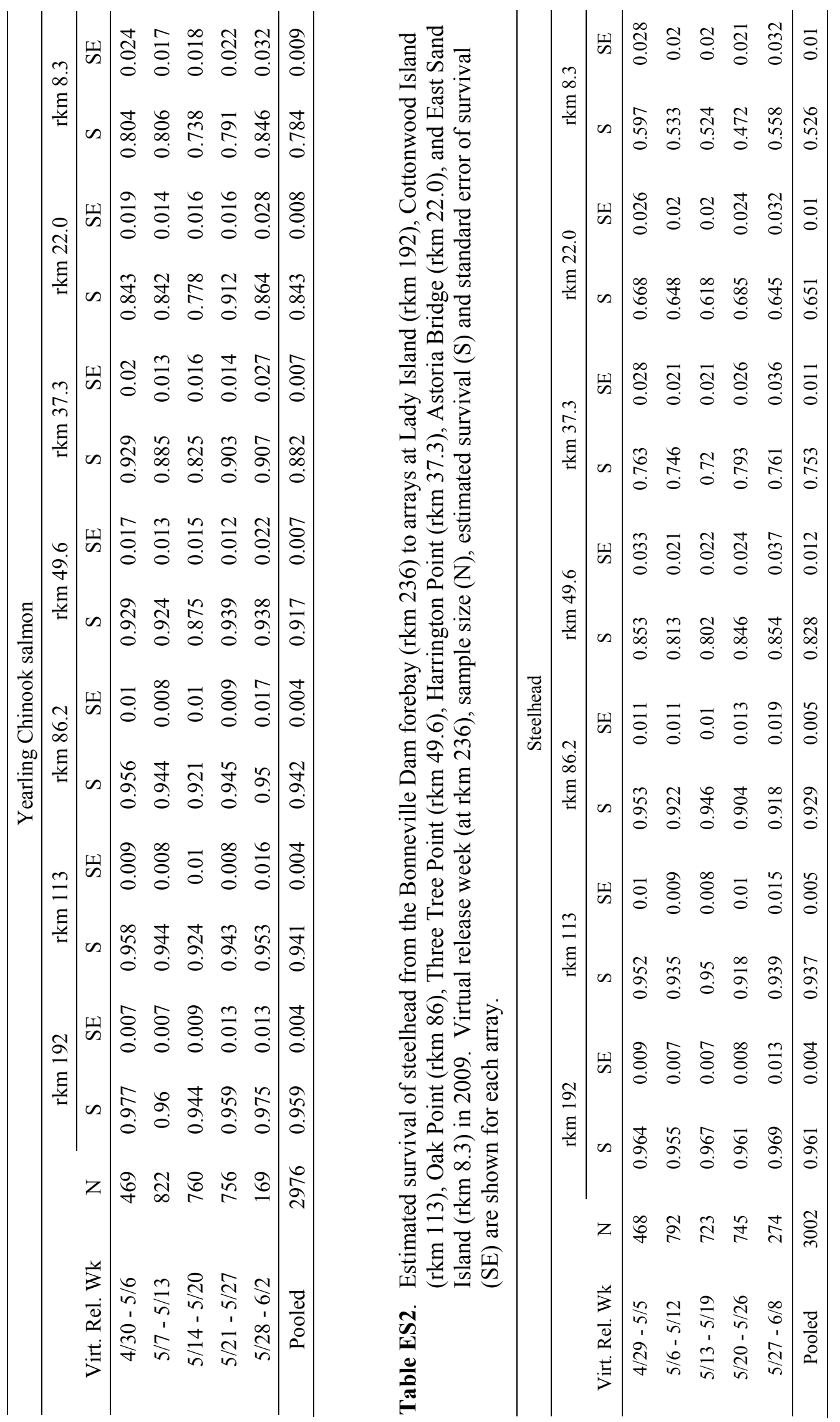




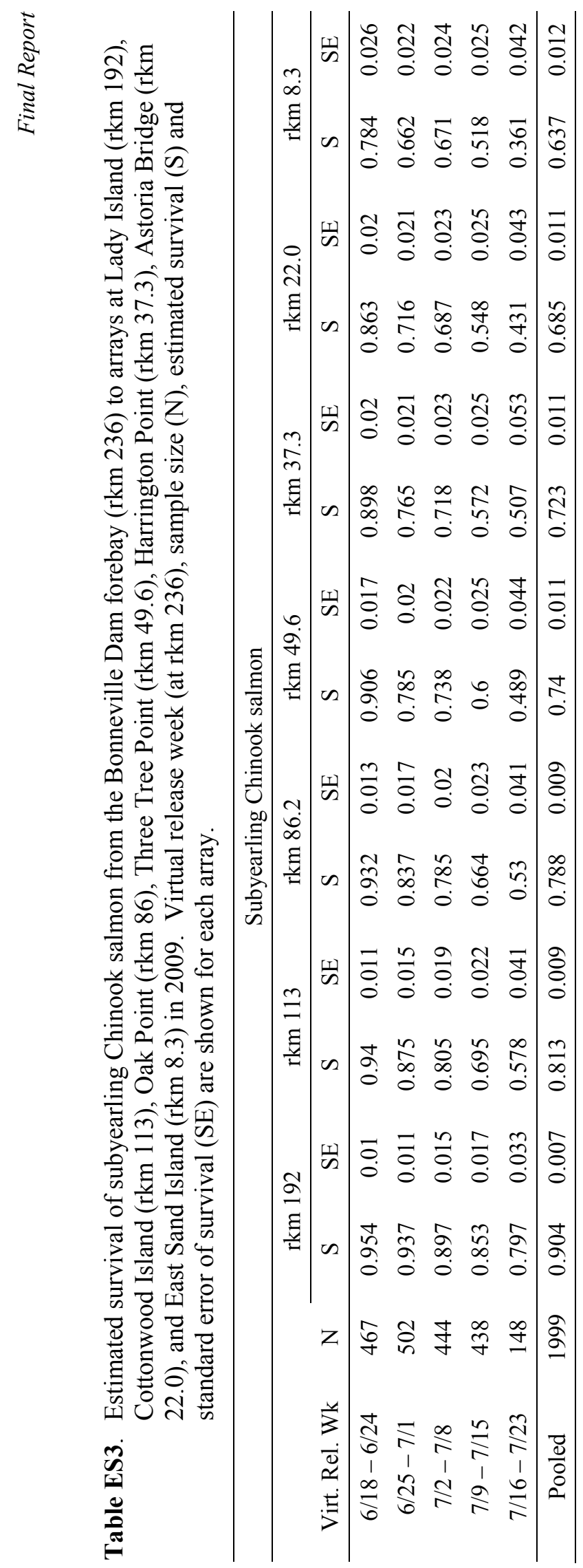




\section{Migration Behavior}

\section{Travel Time}

Acoustic-tagged yearling Chinook salmon that were detected in the Bonneville Dam forebay ( $\mathrm{rkm} 236.0)$ and at the mouth of the Columbia River ( $\mathrm{rkm} \mathrm{8.3;} \mathrm{N}=1999)$ had a mean travel time of $3.4(\mathrm{SE}=0.03) \mathrm{d}$ and a median travel time of $3.1 \mathrm{~d}$ in 2009 . Travel times decreased throughout the migration period from a median of $4.1 \mathrm{~d}$ for the earliest migrants to a median of $2.6 \mathrm{~d}$ for the later migrants. Travel rate of yearling Chinook salmon and steelhead decreased as they moved between Oak Point ( $\mathrm{rkm} \mathrm{86.2)} \mathrm{and} \mathrm{the} \mathrm{Astoria} \mathrm{Bridge} \mathrm{(} \mathrm{rkm} 22$ ) and increased and was more variable downstream of rkm 22. Tagged steelhead followed a similar pattern to that described above for yearling Chinook salmon. Steelhead $(\mathrm{N}=1331)$ had a mean travel time of $3.1(\mathrm{SE}=0.04) \mathrm{d}$ and a median travel time of

$2.9 \mathrm{~d}$. Similar to yearling Chinook salmon, travel times decreased throughout the migration period, from a median of $3.4 \mathrm{~d}$ for the earliest migrants to a median of $2.5 \mathrm{~d}$ for the later migrants. Subyearling Chinook salmon $(\mathrm{N}=1156)$ had a mean travel time of $4.1(\mathrm{SE}=0.04) \mathrm{d}$ and a median travel time of $3.9 \mathrm{~d}$ between $\mathrm{rkm} 236$ and $\mathrm{rkm}$ 8.3. Travel times increased slightly throughout the migration period from a median of $3.5 \mathrm{~d}$ for the earliest migrants to a median of $4.4 \mathrm{~d}$ for the later migrants. Travel rate of subyearling Chinook salmon decreased as they moved between the array at Cottonwood Island (rkm 113) and rkm 22 and increased and was more variable downstream of rkm 22.

\section{Migration Pathways}

A higher percentage of subyearling Chinook salmon detected at Harrington Point (rkm 37.3) were later detected in Grays Bay (26\%) compared to yearling Chinook salmon (9\%) and steelhead (6\%). Regardless of whether fish migrated from Harrington Point in the main navigation channel (south of Rice Island) or outside the main channel (through Grays Bay) the majority of acoustic-tagged yearling and subyearling Chinook salmon and steelhead that were detected at the Astoria Bridge were first detected in the Washington channel, indicating they had crossed through shallow habitats as they moved northward from the navigation channel into the deep channel near the Washington shore.

The probability of survival was high (0.936 to 0.962$)$ for yearling Chinook salmon between Harrington Point (rkm 37.3) and the Astoria Bridge (rkm 22) regardless of the pathway used to migrate from one array to the next. However, subyearling Chinook salmon and steelhead that migrated from the Harrington Point receiver located nearest to the Washington shoreline (the majority of which migrated through Grays Bay), had a significantly lower survival probability than those that migrated from Harrington Point in or near the navigation channel.

\section{Cross-Channel Distribution}

The majority of yearling Chinook salmon were first detected in the Washington channel at the Astoria Bridge (rkm 22). Near East Sand Island (rkm 8.3), yearling Chinook salmon were most frequently first detected halfway between the middle of the channel and the tip of West Sand Island. At the Columbia River Bar (rkm 2.8), the largest proportions of yearling Chinook salmon were first detected south of the navigation channel. 
The distribution of steelhead at the Astoria Bridge (rkm 22) was similar to yearling Chinook salmon, with the greatest percentage of steelhead first detected in the Washington channel. However, a greater percentage of steelhead was detected in the middle of the river and in the Oregon channel (navigation channel) than was observed for yearling Chinook salmon at the Astoria Bridge. At rkm 8.3, steelhead were more often detected closer to Clatsop Spit (Oregon shore) than either yearling or subyearling Chinook salmon. At the Columbia River Bar ( $\mathrm{rkm} 2.8$ ), the greatest percentage of steelhead was first detected on the Oregon side of the navigation channel. The cross-channel distribution of subyearling Chinook salmon at the Astoria Bridge ( $\mathrm{rkm} 22$ ) was highly skewed towards the Washington side of the estuary. The distribution of subyearling Chinook salmon at $\mathrm{rkm} 8.3$ was similar to that of yearling Chinook salmon, with the greatest percentage of first detections occurring north of the navigation channel near East Sand Island. In contrast to the cross-channel distributions of yearling Chinook salmon and steelhead, the majority of the subyearling Chinook salmon were first detected at rkm 2.8 on the Washington side (North Jetty) of the navigation channel.

\section{Diel Distribution and Tidal Influence}

The timing of arrival of tagged fish at most arrays in the lower $50 \mathrm{~km}$ of the Columbia River estuary was influenced more by tide than by time of day for yearling and subyearling Chinook salmon and steelhead. Most tagged fish passed the lower three arrays on ebb tides. This relationship was most evident at arrays located closer to the mouth of the river (Astoria Bridge [CR022.0], East Sand Island [CR008.3], and Columbia River Bar [CR002.8]) and when the difference between high and low tide was greatest.

\section{Avian Predation}

PIT tags from a total of 766 JSATS-tagged fish released in 2009 were detected on Caspian tern or double-crested cormorant colonies on East Sand Island. A total of 5.5\% of yearling Chinook salmon detected at the Bonneville Dam forebay array (rkm 236) were detected on the bird colonies. The greatest percentage of yearling Chinook salmon detected on the bird colonies were from the middle three virtual release groups (7 May-27 May). PIT tags from almost 17\% of the steelhead detected at the Bonneville Dam forebay array were recovered on the bird colonies. The trend by virtual release group for steelhead followed that of yearling Chinook salmon, with the middle three groups (6 May-26 May) experiencing the highest predation rate. Ninety-five (95) PIT tags from JSATS-tagged subyearling Chinook salmon were detected on the bird colonies, which was about $5 \%$ of all subyearling Chinook salmon detected at the Bonneville Dam forebay array. The highest predation rate was observed for the first virtual release group of subyearling Chinook salmon, which passed Bonneville Dam during the week of 18 June.

Tags from yearling and subyearling Chinook salmon that were detected on East Sand Island were detected nearly equally between the two colonies, with $53 \%$ and $54 \%$ of the yearling Chinook salmon and subyearling Chinook salmon tags, respectively, detected on the tern colony. In contrast, steelhead appeared to be more vulnerable to predation from Caspian terns; $68 \%$ of the steelhead tags detected on the island were detected on the tern colony.

The greatest percentage of yearling Chinook salmon and steelhead detected on the bird colonies were last detected in the river at the Oak Point array ( $\mathrm{rkm} \mathrm{86.2).} \mathrm{The} \mathrm{highest} \mathrm{percentage} \mathrm{of} \mathrm{subyearling}$ Chinook salmon detected on the bird colonies were last detected in the river near the bird colonies at the East Sand Island array (rkm 8.3). 


\section{Conclusions}

The addition of autonomous receiver arrays to partition the lower Columbia River and estuary into reaches, beginning in 2007, has vastly increased our understanding of the migratory behavior and survival of juvenile salmonids emigrating through the lower $235 \mathrm{~km}$ of the Columbia River and estuary.

Estimated survival of acoustic-tagged juvenile Chinook salmon and steelhead through the lower Columbia River and estuary in 2009 was lowest in the final $50 \mathrm{~km}$ of the estuary. Probability of survival was relatively high $(>0.90)$ for yearling and subyearling Chinook salmon from the Bonneville Dam forebay ( $\mathrm{rkm}$ 236) to Three-tree Point (rkm 49.6). Survival of juvenile Chinook salmon declined sharply through the lower $50 \mathrm{~km}$ of the estuary. Acoustic-tagged steelhead smolts did not survive as well as juvenile Chinook salmon between Bonneville Dam and the mouth of the Columbia River. Steelhead survival began to decline farther upstream (at Oak Point [rkm 86]) relative to that of the Chinook salmon stocks. Subyearling Chinook salmon survival decreased markedly as the season progressed. It remains to be determined whether later migrating subyearling Chinook salmon are suffering increasing mortality as the season progresses or whether some portion of the apparent loss is due to fish extending their freshwater residence.

This study provided the first glimpse into what promises to be a very informative way to learn more about how juvenile salmonid passage experiences through the FCRPS may influence their subsequent survival after passing Bonneville Dam.

New information regarding the influence of migration pathway through the lower $50 \mathrm{~km}$ of the Columbia River estuary on probability of survival of juvenile salmonids, combined with increased understanding regarding the foraging distances and time periods of avian predators should prove useful in developing or assessing management actions to reduce losses of juvenile salmonid smolts that attempt to pass through the estuary on their seaward migration. 


\section{Acknowledgments}

Blaine Ebberts of the U.S. Army Corps of Engineers' Portland District has been a pioneer in identifying and addressing issues related to juvenile salmonid survival, behavior, and habitat use/restoration in the Columbia River estuary. We appreciate the technical, financial, and logistical support Blaine has provided over the course of the development of the JSATS and the survival and behavior studies in the lower Columbia River and estuary. Brad Eppard, also of the Portland District, has provided excellent oversight in the use of JSATS as it relates to survival and dam passage and has been instrumental in the standardization of equipment and protocols related to the use of telemetry equipment for USACE-funded research in the Columbia Basin. Liz Smock of the Portland District was very helpful in coordinating receiver deployment and Corps channel maintenance activities. Dave Nichols of the Ilwaco Fuel Dock was a great host and provided support for our shore-based operations in Ilwaco.

Advanced Telemetry Systems (ATS), Inc. manufactured the JSATS acoustic tags. Autonomous and dam-mounted hydrophones were manufactured by Sonic Concepts Inc., Bothell, Washington. Precision Acoustic Systems, also in Seattle, made the quad channel receivers and conducted node acceptance tests for PNNL. Cascade Aquatics, Inc. in Ellensburg, Washington, activated and delivered the acoustic tags.

Lynn McComas, NOAA Fisheries, has been instrumental in the development and application of JSATS in the lower Columbia River and estuary. Scott Sebring, NOAA Fisheries, provided the PIT tag detection data for JSATS+PIT-tagged fish that were detected on the bird colonies.

We appreciate the help from Rich Townsend and John Skalski, Columbia Basin Research at the University of Washington, who performed the tag life correction analyses and reviewed the report.

We thank the North Bonneville PNNL crew who conducted the JSATS studies in the lower Columbia River in 2009. These people collected and tagged the fish at John Day Dam and provided detection data, including route of passage, for John Day and Bonneville dams. They also provided detection data for JSATS-tagged fish at arrays upstream and downstream of Bonneville Dam. We sincerely appreciate the hard work and help from Mark Weiland, Gene Ploskey, Derrek Faber, James Hughes, Shon Zimmerman, Eric Fischer, Jina Kim, and others in the North Bonneville office. Many other PNNL staff assisted in surgery training (Rich Brown and Kate Deters), JSATS development and route assignments (Eric Choi, Brian LaMarche, Daniel Deng, Tao Fu, Thomas Seim, and Thomas Carlson), and field and equipment maintenance assistance (Kate Hall, Eric Oldenburg, Jim Boyd, Janice O'Reilly, and Greg Gaulke). John Serkowski assisted with map production. Dr. David Geist was the Ecology Group Manager at PNNL, and Stephan Schlahta was the Product Line Manager during this study. 



\section{Acronyms and Abbreviations}

ATS

$\mathrm{BiOp}$

${ }^{\circ} \mathrm{C}$

$\mathrm{CF}$

cfs

CH0

$\mathrm{CH} 1$

CI

CSV

d

DART

$\mathrm{dB}$

FCRPS

$\mathrm{ft}$

$\mathrm{g}$

GPS

$\mathrm{h}$

JBS

JSATS

kcfs

$\mathrm{km}$

L

LRT

$\mathrm{m}$

$\min$

$\mathrm{mL}$

$\mathrm{mm}$

MSL

NA

NOAA

PIT

PNNL

PRI

rkm

$\mathrm{S}$

SMF
Advanced Telemetry Systems, Inc.

Biological Opinion

degree(s) celsius or centigrade

Compact Flash (card)

cubic feet per second

subyearling Chinook salmon smolt

yearling Chinook salmon smolt

confidence interval (1/2 95\%)

comma-separated variables

day(s)

Data Access in Real Time

decibel(s)

Federal Columbia River Power System

foot, feet

$\operatorname{gram}(\mathrm{s})$

Global Positioning System

hour(s)

juvenile bypass system

Juvenile Salmon Acoustic Telemetry System

thousand cubic feet per second

kilometer(s)

liter(s)

likelihood ratio test

meter(s)

minute(s)

milliliter(s)

millimeter(s)

mean sea level

not applicable

National Oceanic and Atmospheric Administration

passive integrated transponder

Pacific Northwest National Laboratory

ping rate interval(s)

river kilometer(s)

second(s)

Smolt Monitoring Facility (John Day Dam) 
STH

TOA

TOAD

TSW

TSWE

TSWEF

$\mu \mathrm{Pa}$

USACE

UW

WEL steelhead smolt

time of arrival

time of arrival difference

top-spill weir

top spillway weir passage efficiency

top spillway weir passage effectiveness

micropascal(s)

U.S. Army Corps of Engineers

University of Washington

Wells Dam 


\section{Contents}

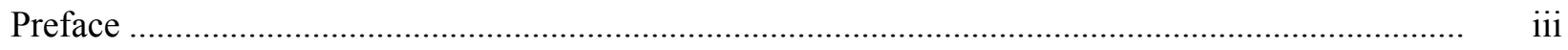

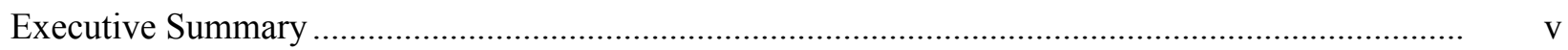

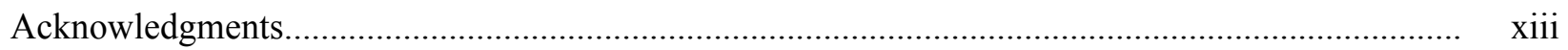

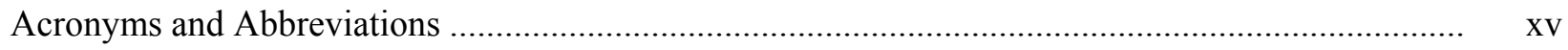

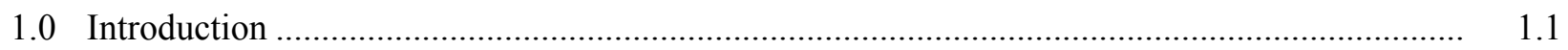

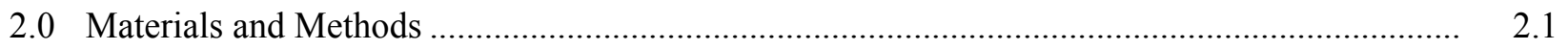

2.1 Fish Collection, Tagging, and Release ..................................................................... 2.1

2.1.1 Collection and Sampling Methods ............................................................... 2.1

2.1.2 Transmitter Specifications and Implantation...................................................... 2.2

2.1.3 Recovery and Holding ............................................................................... 2.3

2.1.4 Fish Transportation and Release ................................................................... 2.3

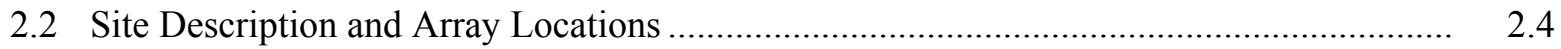

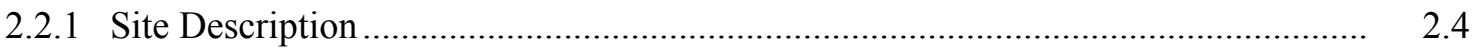

2.2.2 Autonomous Acoustic Receiver Locations ......................................................... 2.6

2.3 Receiver Deployment, Recovery, and Servicing............................................................ 2.7

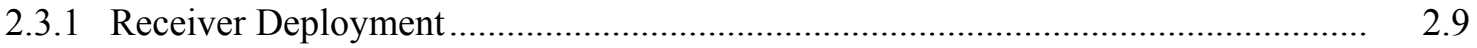

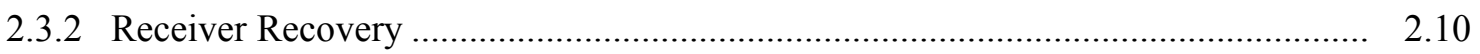

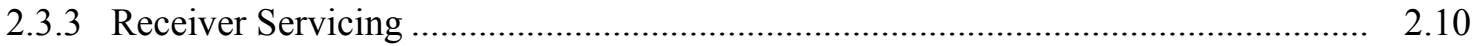

2.4 Autonomous Receiver Data Processing and Validation................................................ 2.10

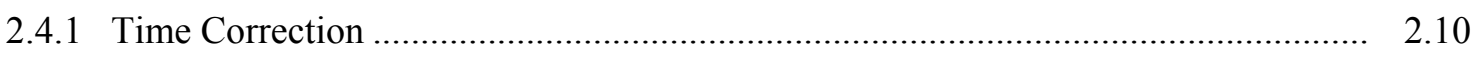

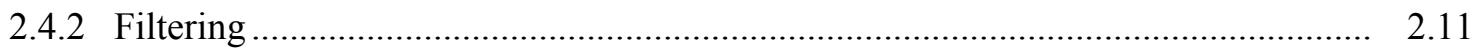

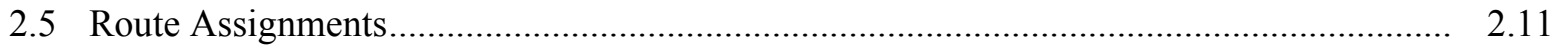

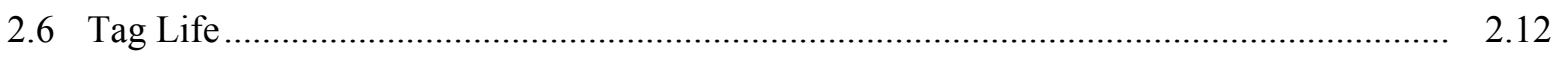

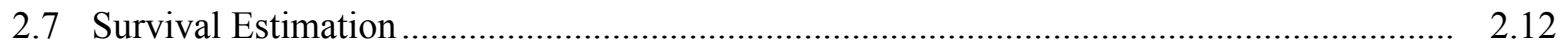

2.7.1 Survival by Dam Passage Route ..................................................................... 2.14

2.7.2 Burnham Tests of Survival Model Assumptions .............................................. 2.14

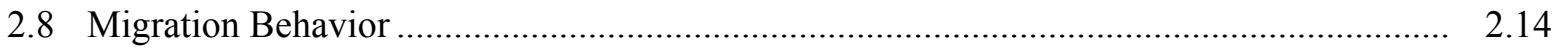

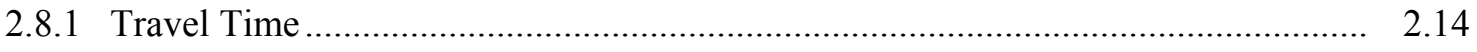

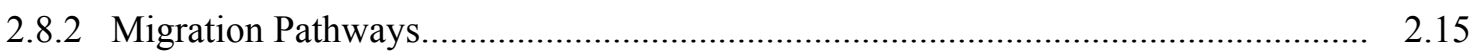

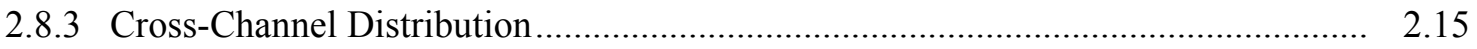

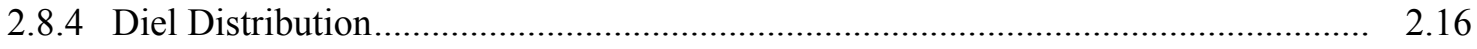

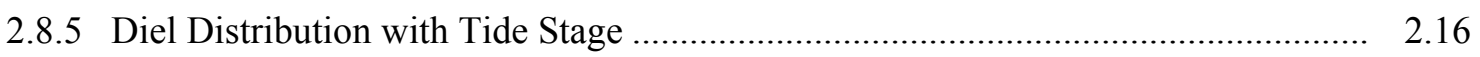

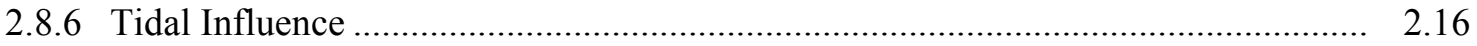

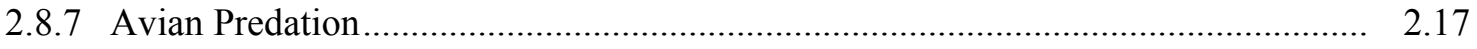

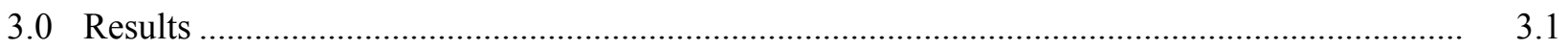

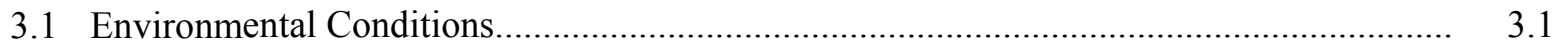


3.2 Smolt Migration Timing and Fish Size .....................................................................

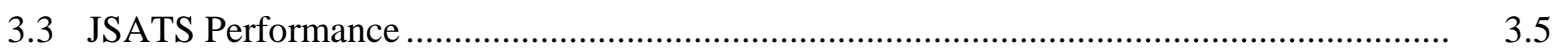

3.3.1 Tag Life Studies ......................................................................................... 3.5

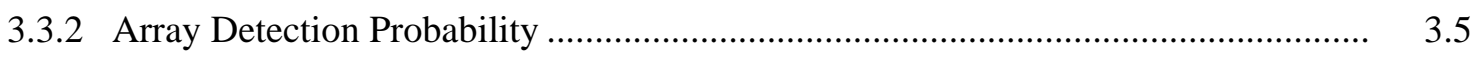

3.3.3 Burnham Tests of Survival Model Assumptions .............................................. 3.9

3.3.4 Survival Probability......................................................................................... 3.10

3.3.5 Survival by Dam Passage Routes .................................................................. 3.16

3.4 Migration Behavior ........................................................................................ 3.17

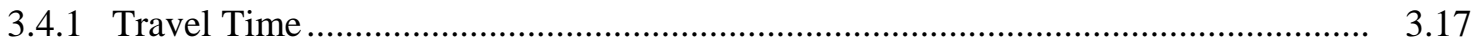

3.4.2 Migration Pathways.................................................................................... 3.20

3.4.3 Cross-Channel Distribution........................................................................... 3.27

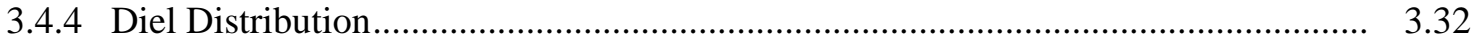

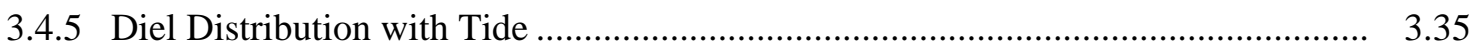

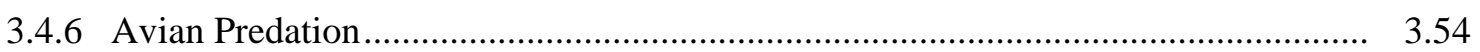

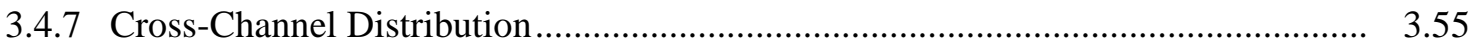

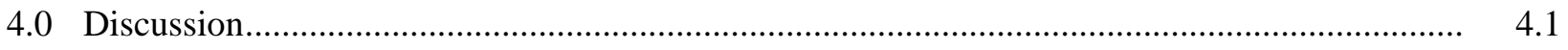

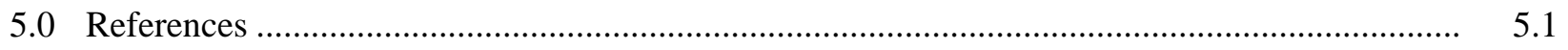

Appendix A - Acoustic-Tagged Fish Releases............................................................................ A.1

Appendix B - Autonomous Receiver Locations................................................................... B. 1

Appendix C - Tag Life and Tag-Life Adjusted Detection Probability and Survival Estimates ........... C.1

Appendix D - Unadjusted Detection Probability and Survival Estimates........................................ D.1

Appendix E - Likelihood Ratio Test Results for Comparison of Survival by Passage Route

History at John Day and Bonneville Dams........................................................................... E.1

Appendix F - Burnham Test 2 and Test 3 Results......................................................................... F.1

Appendix G - Locations of CR022.0, CR008.3, and CR002.8 Receivers from Reference Points for Cross-Channel Distribution Analyses .............................................................................. G.1

Appendix H - Autonomous Receiver Data Gap Chart ................................................................. H.1 


\section{Figures}

2.1 JSATS 0.43 -g acoustic micro-transmitter and PIT tag surgically implanted in yearling and subyearling Chinook salmon and steelhead smolts in 2009 .

2.2 Study site and locations of acoustic telemetry receiver arrays at the Bonneville Dam forebay, Lady Island, Cottonwood Island, Oak Point, Three Tree Point, Harrington Point, Astoria Bridge, East Sand Island, and Columbia River Bar and single receivers in Grays Bay used to detect acoustic-tagged yearling and subyearling Chinook salmon and steelhead migrating through the Columbia River estuary in 2009.

2.3 Locations of acoustic telemetry receiver arrays at Harrington Point and the Astoria Bridge and locations of single receivers in Grays Bay in relation to bathymetry, 2009.

2.4 Locations of acoustic telemetry receiver arrays at East Sand Island and the Columbia River Bar in 2009.

2.5 The JSATS autonomous acoustic receiver, hydrophone, acoustic release, anchor, and mooring used in 2009

3.1 Average daily water discharge during the 2009 study period and the preceding $10-\mathrm{yr}$ average discharge from Bonneville Dam.

3.2 Average daily water temperature in the Bonneville Dam forebay during the 2009 study period and the preceding 10 -year average

3.3 The percentage of yearling and subyearling Chinook salmon and steelhead smolts that emigrated passed John Day Dam and the timing of tagging operations in 2009

3.4 The percentage of yearling and subyearling Chinook salmon and steelhead smolts that passed Bonneville Dam by date

3.5 Length frequency distributions for tagged and untagged steelhead at JDA in 2009 .....

3.6 Length frequency distributions for tagged and untagged yearling Chinook salmon in 2009......

3.7 Length frequency distributions for tagged and untagged subyearling Chinook salmon in 2009.

3.8 Percentage of acoustic transmitters still active by days since activation and the percentage of yearling Chinook salmon, subyearling Chinook salmon, and steelhead first detections at the mouth of the Columbia River by days since tag activation.

3.9 Detection probability of arrays at Lady Island, Cottonwood Island, and Oak Point for each virtual release group of yearling Chinook salmon, steelhead, and subyearling Chinook salmon versus Columbia River discharge measured near Oak Point

3.10 Detection probability of arrays at Three Tree Point and Harrington Point for each virtual release group of yearling Chinook salmon, steelhead, and subyearling Chinook salmon versus Columbia River discharge measured near Oak Point

3.11 Detection probability of arrays at the Astoria Bridge and East Sand Island for each virtual release group of yearling Chinook salmon, steelhead, and subyearling Chinook salmon versus Columbia River discharge measured near Oak Point

3.12 Survival probability of yearling Chinook salmon in 2009 from the Bonneville Dam forebay by week of virtual release at the Bonneville Dam forebay array and all fish pooled.

3.13 Reach survival probability estimates for all acoustic-tagged yearling Chinook salmon detected in 2009 at the Bonneville Dam forebay array..... 
3.14 Survival probability per river kilometer for all acoustic-tagged yearling Chinook salmon detected in 2009 at the Bonneville Dam forebay array.

3.15 Survival probability of acoustic-tagged steelhead from the Bonneville Dam forebay by week of virtual release and all fish pooled in 2009

3.16 Reach survival probability estimates for all acoustic-tagged steelhead detected at the Bonneville Dam forebay array in 2009

3.17 Survival probability per river kilometer for all acoustic-tagged steelhead detected at the Bonneville Dam forebay array in 2009.

3.18 Survival probability of subyearling Chinook salmon from the Bonneville Dam forebay by week of virtual release in 2009.

3.19 Reach survival probability estimates for all subyearling Chinook salmon detected at the Bonneville Dam forebay array in 2009

3.20 Survival probability per river kilometer for all subyearling Chinook salmon detected at the Bonneville Dam forebay array in 2009.

3.21 Travel time of juvenile yearling Chinook salmon from the Bonneville Dam forebay to detection at the Columbia River mouth.

3.22 Travel rate of juvenile yearling Chinook salmon in reaches of the Columbia River from the Bonneville Dam forebay to the river mouth.

3.23 Travel time of juvenile steelhead from the Bonneville Dam forebay to detection at the Columbia River mouth

3.24 Travel rate of juvenile steelhead in reaches of the Columbia River from the Bonneville Dam forebay to the river mouth ......

3.25 Travel time of juvenile subyearling Chinook salmon from the Bonneville Dam forebay to detection at the Columbia River mouth.

3.26 Travel rate of juvenile subyearling Chinook salmon in reaches of the Columbia River from the Bonneville Dam forebay to the river mouth

3.27 Survival probability of acoustic-tagged yearling Chinook salmon from the Harrington Point array to the Astoria Bridge array grouped by receiver of last detection at the Harrington Point array

3.28 Survival probability of acoustic-tagged steelhead from the Harrington Point array to the Astoria Bridge array grouped by receiver of last detection at the Harrington Point array

3.29 Survival probability of acoustic-tagged subyearling Chinook salmon from the Harrington Point array to the Astoria Bridge array grouped by receiver of last detection at the Harrington Point array....

3.30 Travel time of acoustic-tagged yearling Chinook salmon from the Harrington Point array to the Astoria Bridge array grouped by receiver of last detection at the Harrington Point array ....

3.31 Travel time of acoustic-tagged subyearling Chinook salmon from the Harrington Point array to the Astoria Bridge array grouped by receiver of last detection at the Harrington Point array

3.32 Travel time of acoustic-tagged steelhead from the Harrington Point array to the Astoria Bridge array grouped by receiver of last detection at the Harrington Point array

3.33 Cross-channel distribution of acoustic-tagged yearling Chinook salmon first detections at arrays at the Astoria Bridge, East Sand Island, and the Columbia River Bar. 
3.34 Detail of the CR008.3 array near East Sand Island showing the proximity of receiver positions to the pile dike that extends southward from the western tip of East Sand Island.......

3.35 Cross-channel distribution of acoustic-tagged steelhead first detections at arrays at the Astoria Bridge, East Sand Island, and the Columbia River Bar.

3.36 Cross-channel distribution of acoustic-tagged subyearling Chinook salmon detections at arrays at the Astoria Bridge, East Sand Island, and the Columbia River Bar.

3.37 Hourly distributions of first detections of yearling Chinook salmon at Columbia River arrays at Three Tree Point, Harrington Point, Astoria Bridge, East Sand Island, and Columbia River Bar ....

3.38 Hourly distributions of steelhead first detections at Columbia River arrays at Three Tree Point, Harrington Point, Astoria Bridge, East Sand Island, and Columbia River Bar

3.39 Hourly distributions of subyearling Chinook salmon first detections at Columbia River arrays at Three Tree Point, Harrington Point, Astoria Bridge, East Sand Island, and Columbia River Bar....

3.40 Hourly distribution at the Three Tree Point array for all yearling Chinook salmon ................. 3.36

3.41 Hourly distribution at the Harrington Point array for all yearling Chinook salmon ................. 3.37

3.42 Hourly distribution at the Astoria Bridge array for all yearling Chinook salmon..................... 3.38

3.43 Hourly distribution at the East Sand Island array for all yearling Chinook salmon.................. 3.39

3.44 Hourly distribution at the Columbia River Bar array for all yearling Chinook salmon ............. 3.40

3.45 Hourly distribution at the Three Tree Point array for all steelhead.......................................... 3.41

3.46 Hourly distribution at the Harrington Point array for all steelhead .......................................... 3.42

3.47 Hourly distribution at the Astoria Bridge array for all steelhead ........................................... 3.43

3.48 Hourly distribution at the East Sand Island array for all steelhead .......................................... 3.44

3.49 Hourly distribution at the Columbia River Bar array for all steelhead .................................. 3.45

3.50 Hourly distribution at the Three Tree Point array for all subyearling Chinook salmon............. 3.46

3.51 Hourly distribution at the Harrington Point array for all subyearling Chinook salmon............. 3.47

3.52 Hourly distribution at the Astoria Bridge array for all subyearling Chinook salmon ............... 3.48

3.53 Hourly distribution at the East Sand Island array for all subyearling Chinook salmon ............. 3.49

3.54 Hourly distribution at the Columbia River Bar array for all subyearling Chinook salmon ........ 3.50

3.55 Percentage of first detections of yearling Chinook salmon on arrays at Three Tree Point, Harrington Point, the Astoria Bridge, East Sand Island, and the Columbia River Bar versus change in tide elevation

3.56 Percentage of first detections of steelhead on arrays at Three Tree Point, Harrington Point, the Astoria Bridge, East Sand Island, and the Columbia River Bar versus change in tide elevation

3.57 Percentage of first detections of subyearling Chinook salmon on arrays at Three Tree Point, Harrington Point, the Astoria Bridge, East Sand Island, and the Columbia River Bar versus change in tide elevation.

3.58 Cross-channel distribution of all yearling Chinook salmon and those whose tags were recovered on the East Sand Island bird colonies on arrays at the Astoria Bridge, East Sand Island, and the Columbia River Bar. 
3.59 Cross-channel distribution of all subyearling Chinook salmon and those whose tags were recovered on the East Sand Island bird colonies on arrays at the Astoria Bridge, East Sand Island, and the Columbia River Bar.

3.60 Cross-channel distribution of all steelhead and those whose tags were recovered on the East Sand Island bird colonies on arrays at the Astoria Bridge, East Sand Island, and the Columbia River Bar.

\section{Tables}

2.1 Criteria for accepting or rejecting smolts for implantation surgery.

3.1 Survival of yearling Chinook salmon from the Lady Island array to the East Sand Island array by routes of passage at John Day and Bonneville dams.

3.2 Survival of steelhead from the Lady Island array to the East Sand Island array by routes of passage at John Day and Bonneville dams, 2009.

3.3 Survival of subyearling Chinook salmon from the Lady Island array to the East Sand Island array by routes of passage at John Day and Bonneville dams

3.4 Number of acoustic-tagged yearling and subyearling Chinook salmon and steelhead last detected at each receiver of the Harrington Point array, and of those, the number and percentage detected in Grays Bay, and the number and percentage first detected in each channel at the Astoria Bridge array.

3.5 Number and percentage of JSATS+PIT-tagged yearling and subyearling Chinook salmon and steelhead from each virtual release group whose PIT tags were detected on the East Sand Island bird colonies.

3.6 Numbers and percentages of fish whose tags were detected on the East Sand Island bird colonies by location of last in-river detection and the detection probability of each array

4.1 Single release CJS survival probabilities of acoustic-tagged yearling Chinook salmon from Bonneville Dam to the mouth of the Columbia River and intermediate detection arrays.

4.2 Single release CJS survival probabilities of acoustic-tagged subyearling Chinook salmon from Bonneville Dam to the mouth of the Columbia River and intermediate detection arrays 


\subsection{Introduction}

Since 1991, 13 Columbia River salmon stocks have been added to the list of threatened or endangered species under the Endangered Species Act, which has prompted research focused on the survival and recovery of these stocks. Much of the research has focused on survival and behavior of juvenile salmonids as they pass through reservoirs and dams within the Federal Columbia River Power System (FCRPS). Efforts by the U.S. Army Corps of Engineers (USACE) to improve passage conditions at FCRPS dams have increased survival at many of these dams over the past decade. However, until recently, little research focused on the survival and behavior of seaward migrating juvenile salmonids after they had passed Bonneville Dam (river kilometer (rkm) 235). Questions remain regarding whether the passage experience of a juvenile salmonid through the FCRPS may influence its probability of survival as it migrates through the lower $235 \mathrm{~km}$ of the Columbia River and its estuary. Some researchers have suggested that the previous passage experience through the FCRPS may influence the survival of juvenile salmonids as they transit the lower Columbia River and estuary (Budy et al. 2002; Ferguson et al. 2006; Schreck et al. 2006; Schaller and Petrosky 2007).

Beginning in 2004, with the first prototype testing of Juvenile Salmon Acoustic Telemetry System (JSATS; McMichael et al. 2010) transmitters and receivers, NOAA Fisheries and the Pacific Northwest National Laboratory (PNNL) have been studying the behavior and survival of seaward migrating juvenile salmonids through the lower $235 \mathrm{~km}$ of the Columbia River and its estuary. Survival estimates from Bonneville Dam to the mouth of the river ( $\mathrm{rkm} 8$ ) in 2005 showed that estimated mean survival was 0.67 $(\mathrm{SE}=0.06)$ and $0.63(\mathrm{SE}=0.11)$ for yearling and subyearling Chinook salmon, respectively (McComas et al. 2007). In 2006, estimated mean survival was $0.75(\mathrm{SE}=0.018)$ for yearling Chinook salmon and $0.65(\mathrm{SE}=0.024)$ for subyearling Chinook salmon (McComas et al. 2008). The average estimated survival through the lower Columbia River and estuary was lower than expected in 2005 and 2006, with between 25 and 33\% of yearling Chinook salmon perishing in the $227 \mathrm{~km}$ between Bonneville Dam and East Sand Island (rkm 8). Subyearling Chinook salmon transiting the same reach suffered 35 to $37 \%$ estimated average losses.

To better understand where fish losses were occurring in the lower Columbia River and its estuary, PNNL deployed additional autonomous receiver arrays in strategic locations to separate the lower $235 \mathrm{~km}$ of the Columbia River and estuary into specific reaches in 2007 and 2008. Information from these additional arrays showed that the majority of the loss of juvenile Chinook salmon occurred in the final $50 \mathrm{~km}$ of the estuary. ${ }^{1}$

This report presents the research conducted in 2009 using the JSATS to estimate survival of acoustictagged juvenile yearling Chinook salmon (CH1), subyearling Chinook salmon (CH0), and steelhead (STH) downstream of Bonneville Dam as they migrated seaward through the Columbia River and its estuary. This study also provides, for the first time, estimates of survival through the lower $192 \mathrm{~km}$ of the Columbia River and its estuary for groups of fish with known passage routes at John Day and Bonneville dams. The research presented in this report was conducted by the PNNL for the USACE Portland District.

\footnotetext{
${ }^{1}$ McComas et al. in prep.
} 
The primary objective of this study was

- to estimate the survival of yearling and subyearling Chinook salmon and steelhead through multiple reaches of the Columbia River between Bonneville Dam and the Pacific Ocean.

Other objectives were

- to compare the effects of FCPRS passage history on mortality of juvenile salmonids in the lower $192 \mathrm{~km}$ of the Columbia River and estuary

- to monitor and map migration pathway and habitat associations and behaviors relative to these pathways to support habitat restoration activities.

The ensuing sections of this report present the materials and methods (Section 2), results (Section 3), and discussion (Section 4). References may be found in Section 5. Eight appendices contain tagging data tables (Appendix A); autonomous receiver locations (Appendix B); plots of tag life and tag life corrected survival estimates (Appendix C); survival and detection probabilities without tag-life corrections (Appendix D); likelihood ratio test results (Appendix E); Burnham Test 2 and Test 3 results (Appendix F); locations of autonomous receivers relative to reference points for cross-channel distribution (Appendix G); and data gap chart for autonomous receiver files (Appendix $\mathrm{H}$ ). 


\subsection{Materials and Methods}

\subsection{Fish Collection, Tagging, and Release}

\subsubsection{Collection and Sampling Methods}

Juvenile Chinook salmon and steelhead were collected and tagged at the John Day Dam smolt monitoring facility (SMF) as part of the "Studies of Surface Spill at John Day Dam" study (SPE-P-08-03). The SMF is situated on the south side of John Day Dam at the downriver edge of the fish bypass system where bypassed juvenile salmonids and other fishes are routed through a series of flumes and dewatering structures. Juvenile salmonids were diverted from the bypass system and routed into a 6800-L holding tank in the SMF. About 150-200 smolts and other fishes were crowded with a panel net into a $51-$ by $61-\mathrm{cm}$ pre-anesthetic chamber. Water levels in the chamber were lowered to about $20 \mathrm{~cm}$ (48 L) at which point fish were anesthetized with $60 \mathrm{~mL}$ of a stock tricaine methanesulfonate (MS-222) solution prepared at a concentration of $50 \mathrm{~g} / \mathrm{L}$. Once anesthetized, fish were routed into the examination trough. Technicians added MS-222 as needed to maintain sedation, and 5 to $10 \mathrm{~mL}$ of PolyAqua was added to reduce fish stress. Water temperatures were monitored in the main holding tank and in the examination trough, and water in the trough was refreshed before temperatures there increased more than $2^{\circ} \mathrm{C}$ above those observed in the main holding tank.

Once in the examination trough, smolts targeted for surgical procedures were evaluated in accordance with the specific criteria listed in Table 2.1. During spring and summer tagging seasons, 90 of the 10922 $(0.82 \%)$ fish collected for tagging were rejected based on these criteria.

Table 2.1. Criteria for accepting or rejecting smolts for implantation surgery.

\begin{tabular}{|c|c|}
\hline Qualifying (Acceptable) Conditions & Disqualifying (Unacceptable) Conditions \\
\hline $\begin{array}{ll}\text { - } & \text { sized }>95 \mathrm{~mm} \\
\text { - } & \text { visible elastomer tag(s) present or absent } \\
\text { - } & \text { trematodes, copepods, leeches } \\
\text { - } & \text { short operculum } \\
\text { - } & \text { healed (moderate) injuries (e.g., bird strikes) } \\
\text { - } & \quad \text { minor fin blood } \\
\text { - } & \text { partial descaling (3-19\%) } \\
\text { - STH with eroded pectoral or ventral fins } \\
\text { (likely hatchery steelhead). }\end{array}$ & $\begin{array}{l}\text { - } \quad 20 \% \text { descaling } \\
\text { body punctures (showing blood e.g., predator marks, } \\
\text { - } \quad \text { obvious signs of bacterial kidney disease } \\
\text { - } \quad \text { eye hemorrhage or pop eye } \\
\text { - } \quad 3 \% \text { coverage with fungus } \\
\text { - } \quad \text { deformed } \\
\text { - } \text { soldovers (fish not "spring" yearling or "summer" } \\
\text { - } \quad \text { passive integrated transponder (PIT)- or radio-tagged or } \\
\text { - } \quad \text { nother post-surgical fishes } \\
\text { - } \quad \text { columnaris, furuncles } \\
\text { - injured caudal peduncles } \\
\text { - injured caudal fins } \\
\text { - } \quad \text { fin hemorrhage. }\end{array}$ \\
\hline
\end{tabular}


Non-target species and fish that did not meet the criteria were released to the river through the SMF holding system after a 30-minute recovery period. Accepted fish were counted and released into transfer buckets containing fresh river water before being moved to one of six 300-L pre-surgery holding tanks, where they were held for 18 to 30 hours before surgery. The pre-surgery holding duration depended on the time of collection and the time of tagging on the next day.

\subsubsection{Transmitter Specifications and Implantation}

Specifications of the JSATS acoustic tags used in 2009 (Figure 2.1) were as follows: dimensions $(\mathrm{mm})=12$ long x 5.21 wide $\times 3.77$ deep; mass $(\mathrm{g})=0.43$ in air and 0.29 in water; volume $(\mathrm{mL})=0.14$. The nominal pulse repetition rate was one ping every 3 seconds, and this rate provided an expected tag life of at least 23 days (Appendix C).

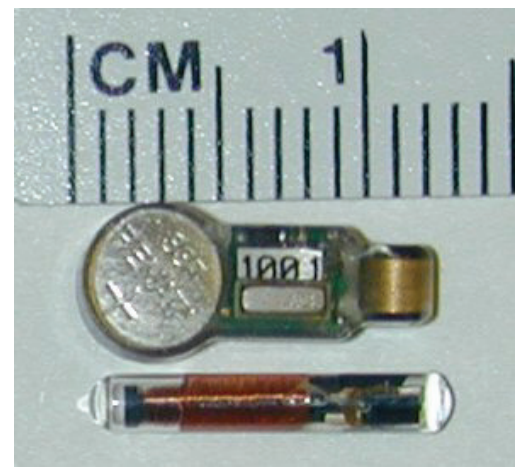

Figure 2.1. JSATS 0.43 -g acoustic micro-transmitter and PIT tag surgically implanted in yearling and subyearling Chinook salmon and steelhead smolts in 2009.

A team of eight people was part of the tagging process to reduce the handling time between netting and post-surgery recovery. The team followed the latest guidelines for surgical implantation of acoustic transmitters in juvenile salmonids. Procedure development is an ongoing process initiated by the USACE for contractors conducting survival studies. Numerous steps were taken to minimize the handling impacts of collection and surgical procedures. Most smolts used for tagging were part of the routine collection for SMF monitoring and additional fish did not have to be collected to meet the tagging quota on most days.

Fish were netted in small groups from the 300-L holding tanks and placed in a 19-L "knockdown" bucket with water and $20 \mathrm{~mL}$ of a $40-\mathrm{g} / \mathrm{L}$ stock solution of MS-222. Once a fish lost equilibrium, it was transferred to a processing table in a small container of river water. Each fish was measured (fork length $\pm 1 \mathrm{~mm}$ ), the species type and whether its adipose fin was intact or clipped were recorded on a GTCO CalComp Drawing Board VI digitizer board. Fish were weighed $( \pm 0.01 \mathrm{~g})$ on an Ohaus Navigator scale and returned to the small transfer container along with an assigned PIT tag and an activated acoustic tag. Length, weight, species type, tag codes, and fin clip were all added automatically into the tagging database by PIT Tag Information System (PTAGIS) P3 software to minimize human error. The transfer container, fish, and tags were assigned a recovery bucket number and passed to a surgeon for tag implantation.

An established protocol was used in the tagging process to help minimize the handling impact on tagged fish. All surgical instruments were sterilized daily in an autoclave and each surgeon used four 
complete sets of instruments during each day's tagging. When a set was not being used, it was placed in a $70 \%$ ethanol solution for approximately 10 minutes. The instruments were then transferred to a distilled water bath for 10 minutes, to remove residual ethanol and any remaining particles, before being used again. To reduce the disruption of the mucus membrane at the incision, Poly-Aqua was used to help replace the membrane that was removed from the fish's epidermal layers. Anesthesia buckets were kept within $\pm 1^{\circ} \mathrm{C}$ of river temperature. Anesthesia solutions were either replaced or cooled with ice when temperatures exceeded protocols. Recovery buckets were also kept within $\pm 1^{\circ} \mathrm{C}$ of river water temperature.

During surgery, each fish was placed ventral side up and a gravity-fed anesthesia supply line was placed into its mouth. The dilution of this "maintenance" line was $40 \mathrm{mg} / \mathrm{L}$. A 6-8-mm incision, using a \#15 stainless steel surgical blade or a Micro-Sharp stab scalpel with a 5-mm blade (depending on the surgeon's preference), was made ventrally, $3 \mathrm{~mm}$ from and parallel to the mid-ventral line and equidistant from the pelvic girdle and pectoral fin. The PIT tag was inserted first, followed by the acoustic tag. Both tags were inserted toward the anterior portion of the fish. Two interrupted sutures of 5-0 monofilament with an RB-1 needle were used to close the incision. With the incision closed, fish were then taken to an aerated recovery bucket containing river water.

\subsubsection{Recovery and Holding}

Tagged fish were placed in 19-L aerated recovery buckets and closely monitored until fish had reestablished equilibrium. Each bucket held two to seven fish depending on the size of the fish and the number to be released at each site. The buckets were then carried to a larger holding tank where they were supplied with a continuous feed of river water. Fish were held and monitored for 18 to 30 hours prior to being released. The large holding tanks were insulated to keep the water temperature within acceptable limits.

\subsubsection{Fish Transportation and Release}

To transport tagged fish, a $3 / 4$-ton truck was outfitted with one 680 -L Bonar insulated tote and one 265-L Bonar insulated tote. The 680-L tote could hold ten 19-L fish buckets, and the 265-L tote could hold four 19-L fish buckets. The totes had snug-fitting lids and some extra space inside so that ice could be added for cooling on hot days. A network of valves and plastic tubing was attached to an oxygen tank for delivering oxygen to the totes from a 2200-psi oxygen tank during transport. The Bonar totes were filled with fresh river water before fish buckets were removed from the post-surgery holding tanks and placed in the totes. Air lines were then placed into the totes. A YSI meter was used to measure the dissolved oxygen and the temperature of water in the totes before and after transport to make sure that these properties stayed within acceptable limits.

Just before fish were released in the river, fish buckets were opened to check for dead fish. Every dead fish was scanned with a portable transceiver PIT-tag scanner to identify the implanted PIT-tag code. The associated acoustic tag code was identified later from tagging data which recorded all pairs of PIT and acoustic tag implanted in fish the previous day. PIT and acoustic tags in dead fish were recovered, sterilized, and implanted in a live fish the next day. Post-tagging, pre-release mortalities were low for each run of fish studied in $2009(\mathrm{CH} 1=0.2 \%$; ST $=0 \%$; $\mathrm{CH} 0=0.46 \%)$. 
During spring, a total of 3470 implanted yearling Chinook salmon and 3471 implanted steelhead were released over a 30-day period from April 27 to May 26 (Appendix A, Tables A.1 and A.2). During summer, a total of 3461 implanted subyearling Chinook salmon were released over a 30-day period from June 16 to July 15 (Table A.3). The JSATS-tagged fish from each of the three stocks were released daily during the spring and summer release periods. Fish were released from a boat $41 \mathrm{rkm}$ upstream of John Day Dam near Roosevelt, Washington, at three locations along a line transect across the river, unless river conditions were too rough for safe boat operation. The release location on the Oregon side of the channel had the longest fetch (i.e., distance with uninterrupted exposure to wind) followed by the mid-channel location. Sometimes the Oregon location, and less often, the Oregon and mid-channel locations had to be skipped because strong winds generated waves that could swamp or capsize a boat. On one occasion (July 12 at 2000 hours), river conditions were too rough to release fish from a boat, so fish were released from a nearby point of land that extended out into the river from the Washington shore.

For boat releases, fish buckets were moved from the Bonar transport totes into the stern of the boat. In preparation for fish release, the boat operator maneuvered the boat to the release waypoint using an onboard global positioning system (GPS) and put the motor in neutral. Each bucket was submerged in the water so that fish could swim out on their own volition. The release site and time were recorded to the nearest minute on field data sheets.

\subsection{Site Description and Array Locations}

\subsubsection{Site Description}

In order to accurately assess the effects of passage through the Federal Columbia River Power System on the survival of juvenile salmonids it is necessary to monitor the migration of these populations over a large enough area to detect delayed/latent mortality that may have been due to the passage history of these fishes. Therefore, the study area included the unimpounded mainstem Columbia River and estuary from Bonneville Dam tailrace to the Pacific Ocean, a distance of approximately 235 river kilometers (rkm, Figure 2.2). This section of the (lower) Columbia River has six (6) major tributaries. The first two major tributaries downstream of Bonneville Dam are the Sandy (Oregon) and Washougal (Washington) rivers, both entering the Columbia River at rkm 195; followed downstream by the Willamette River (rkm 164), Lewis River (rkm 140), Kalama River (rkm 114), and the Cowlitz River (rkm 109). An additional three (3) tributaries enter the Columbia River Estuary; they include the Grays River (rkm 24), Young's River (rkm 19), and Lewis and Clark River, also at rkm 19.

Physical processes in the lower Columbia River are shaped by two dominant factors, channel bathymetry and flow. River flow is controlled by climate variation and anthropogenic effects such as water storage, irrigation withdrawals, and flood control/flow regulation (McComas et al. 2007). The annual discharge for the Columbia River ranges from a low of $2,970 \mathrm{~m}^{3} / \mathrm{s}$ during late summer and fall to a high of $17,000 \mathrm{~m}^{3} / \mathrm{s}$ during the spring freshet period (Sherwood and Greagar 1990). Under post dam flow conditions, annual sediment discharge is about $7.6 \times 106 \mathrm{mt}^{3} / \mathrm{y}$, about $45 \%$ of which is sand (Sherwood et al. 1990). The authors also noted that much of the finer material is transported in suspension during periods of high river flow. Thus, both high flows and high suspended sediment loads coincide with the peak juvenile salmonid outmigration, particularly for yearling Chinook salmon and steelhead, which migrate through the system during the spring freshet (McComas et al. 2007). 


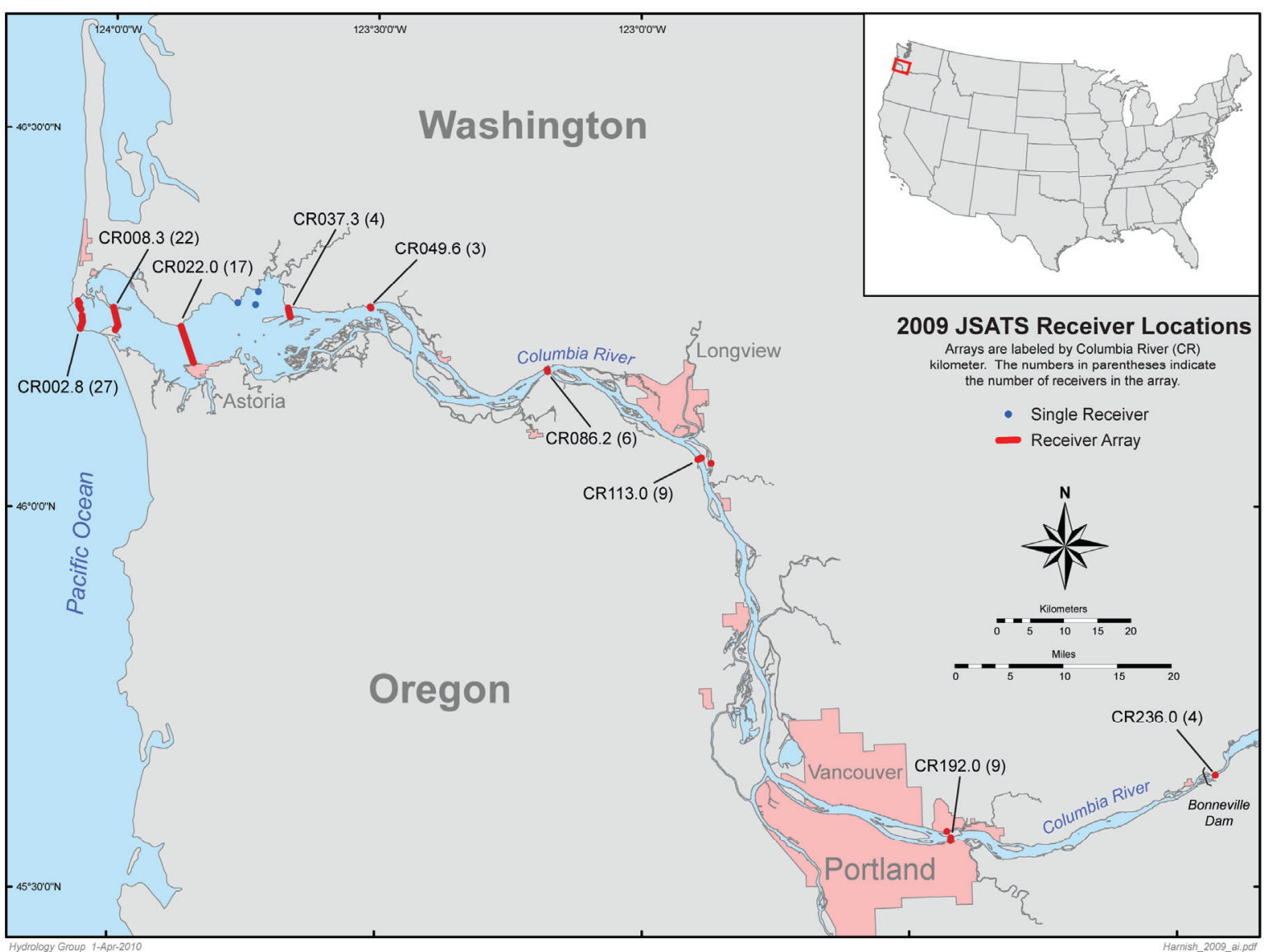

Figure 2.2. Study site and locations of acoustic telemetry receiver arrays (red) at the Bonneville Dam forebay (CR236.0), Lady Island (CR192.0), Cottonwood Island (CR113.0), Oak Point (CR086.2), Three Tree Point (CR049.6), Harrington Point (CR037.3), Astoria Bridge (CR022.0), East Sand Island (CR008.3), and Columbia River Bar (CR002.8) and single receivers (blue) in Grays Bay used to detect acoustic-tagged yearling and subyearling Chinook salmon and steelhead migrating through the Columbia River estuary in 2009. The number of receivers in each array is shown in parentheses.

The physical characteristics of the Columbia River Estuary are different than most other estuaries, as river discharge is relatively large (accounting for $77 \%$ of the freshwater drainage along the U.S. west coast north of San Francisco) and the river sediment is less stable (Fox et al. 1984; Hickey et al. 2005). Tidal exchange between the high and low tide changes the estuary water level by an average of $2.4 \mathrm{~m}$ in approximately $6 \mathrm{~h}$ (Fox et al. 1984). Tidal effects reach as far inland as Bonneville Dam (rkm 235). This large tidal exchange and river discharge significantly influences water velocity and direction in the Columbia River estuary (Fox et al. 1984), where water velocity consistently reaches $2 \mathrm{~m} / \mathrm{s}^{1}{ }^{1}$ Flood tides will actually reverse the river flow from an outgoing current to upstream current flow. The estuary bottom is composed mostly of sand that constantly shifts; building sand waves that move in response to strong water flows and large waves, a process called bedload transport (White 1970; Fox et al. 1984). Sand waves cover approximately $45 \%$ of the channel near Bonneville Dam and increase to $86 \%$ at the mouth of the Columbia River (Woxell 1998).

\footnotetext{
${ }^{1}$ Data are from the Columbia River Ecosystem (CORIE) observatory network operated by The Center for Coastal Margin Observation \& Prediction, Beaverton, Oregon.
} 
The Columbia River Estuary contains numerous natural islands as well as several man-made islands constructed of dredge spoils (Sherwood et al. 1990). Collis et al. (2001) estimated that nine islands in the estuary supported up to 170,000 piscivorous water birds, including the largest nesting colonies of Caspian terns Sterna caspia and double-crested cormorants Phalacrocorax auritus in North America. Two of these islands were particularly important to survival studies of fish migrating through the study area. Rice Island, a dredge spoils site at rkm 35 contained over 16,000 breeding pairs of terns, which were estimated to be dependent on salmonids for $74 \%$ of their diet (Collis et al. 2002). Subsequent relocation efforts successfully moved a majority of these birds to East Sand Island, another dredge disposal site at $\mathrm{rkm} 10$, where a colony of about 8,500 breeding pairs was established by 2002 . In addition to the terns, Ryan et al. (2005) cited presence of a colony of about 8,000 breeding pairs of double-crested cormorants on a $15,000-\mathrm{m}^{2}$ area of rock jetty attached to East Sand Island. The colony of cormorants on Rice Island had decreased from 1,082 birds in 1998 (Collis et al. 2002) to no nesting pairs by 2002 (Roby et al. 2005).

\subsubsection{Autonomous Acoustic Receiver Locations}

For this study, acoustic telemetry receivers were deployed at 104 locations from the forebay of Bonneville Dam (rkm 236) downstream to the mouth of the Columbia River between April 22 and August 27, 2009 to detect acoustic-tagged Chinook salmon and steelhead smolts as they migrated through the Columbia River estuary (Figure 2.2). Receivers were deployed primarily in lines that ran perpendicular to shore, referred to as arrays, with receivers spaced about 100-200 m apart (Appendix B, Table B.1). Receiver arrays were deployed across the entire river channel in the forebay of Bonneville Dam (rkm 236.0), at Lady (rkm 192.0) and Cottonwood (rkm 113.0) islands, at Oak Point (rkm 86.2), and at two locations near the mouth of the river at East Sand Island (rkm 8.3) and the Columbia River Bar (rkm 2.8; Figure 2.3). Partial arrays were deployed across the primary channel at Three Tree Point (rkm 49.6), Harrington Point (rkm 37.3), and at the Astoria Bridge (rkm 22.0; Figure 2.4). The Astoria Bridge array consisted of 17 total receivers-10 deployed across the Washington shoreline channel, 1 near the middle of the bridge, and 6 across the Oregon shoreline channel. Deployment of receivers at the Astoria Bridge was limited to areas that were deep enough to allow boat access and ensure that receiver hydrophones remained submerged during periods of low flows (ebb tides). In addition to these arrays, 3 single receivers were deployed in Grays Bay ( $\mathrm{rkm} 34.0$ and 29.3; Figure 2.4) to provide information about the use of off-channel areas by out-migrating smolts.

Receiver locations are named as a concatenation of "CR" for Columbia River, the river kilometer location of the receiver (measured upstream from the mouth of the Columbia River), followed by an underscore, and the receiver number (numbered from the Washington to the Oregon shore). For example, the receiver location CR002.8_01 is the concatenation of "CR" (for Columbia River), "002.8" describing the river kilometer of the receiver, and an underscore followed by " 01 ", which is the receiver location on that array. Receivers in all arrays were numbered sequentially from the Washington shoreline to the Oregon shoreline except at arrays CR002.8 and CR008.3 where numbers representing past locations of receivers in the navigation channel were omitted. Receivers were not deployed in the navigation channel at CR002.8 and CR008.3 in 2009. 


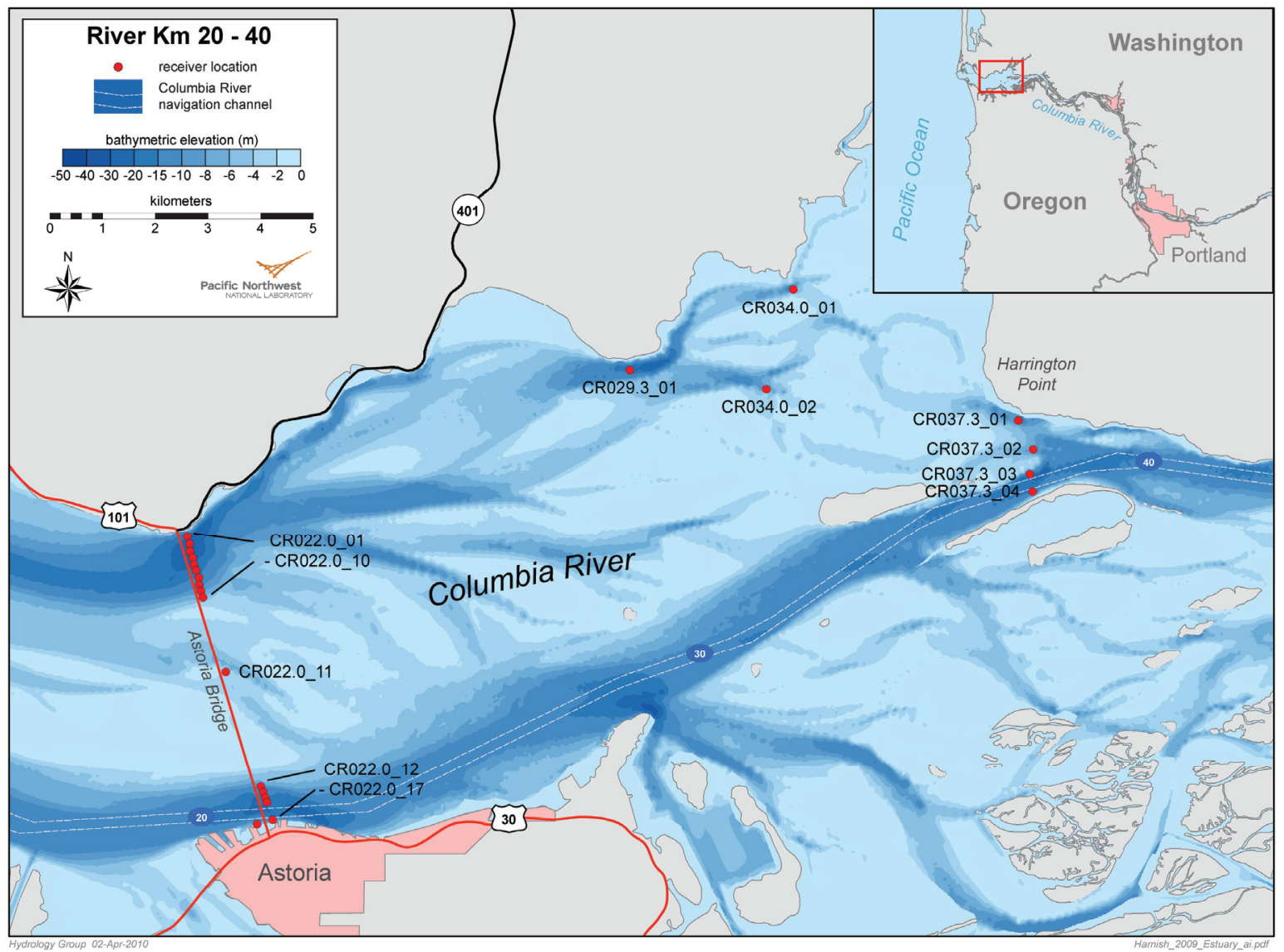

Figure 2.3. Locations of acoustic telemetry receiver arrays at Harrington Point (CR037.3) and the Astoria Bridge (CR022.0) and locations of single receivers in Grays Bay (CR034.0_01, CR034.0_02, and CR029.3_01) in relation to bathymetry, 2009.

\subsection{Receiver Deployment, Recovery, and Servicing}

The JSATS autonomous acoustic receiver (Model N201, Sonic Concepts, Bothell, Washington) consisted of a hydrophone, electronic components powered by a single lithium battery pack (power for 30 days), and compact flash (CF) card mounted in a 1.2-m-long x 15-cm-diameter yellow cylindrical polyvinyl chloride (PVC) plastic housing. The autonomous receiver weighed approximately $9.6 \mathrm{~kg}$ in air and had approximately $3.0 \mathrm{~kg}$ net buoyancy in fresh water. Each receiver also carried a beacon that transmitted a unique code every 15 seconds and a label that identified the manufacturer; contact information, including indication of a reward for return if found; serial number; lithium battery warning; and intended use of the equipment. 


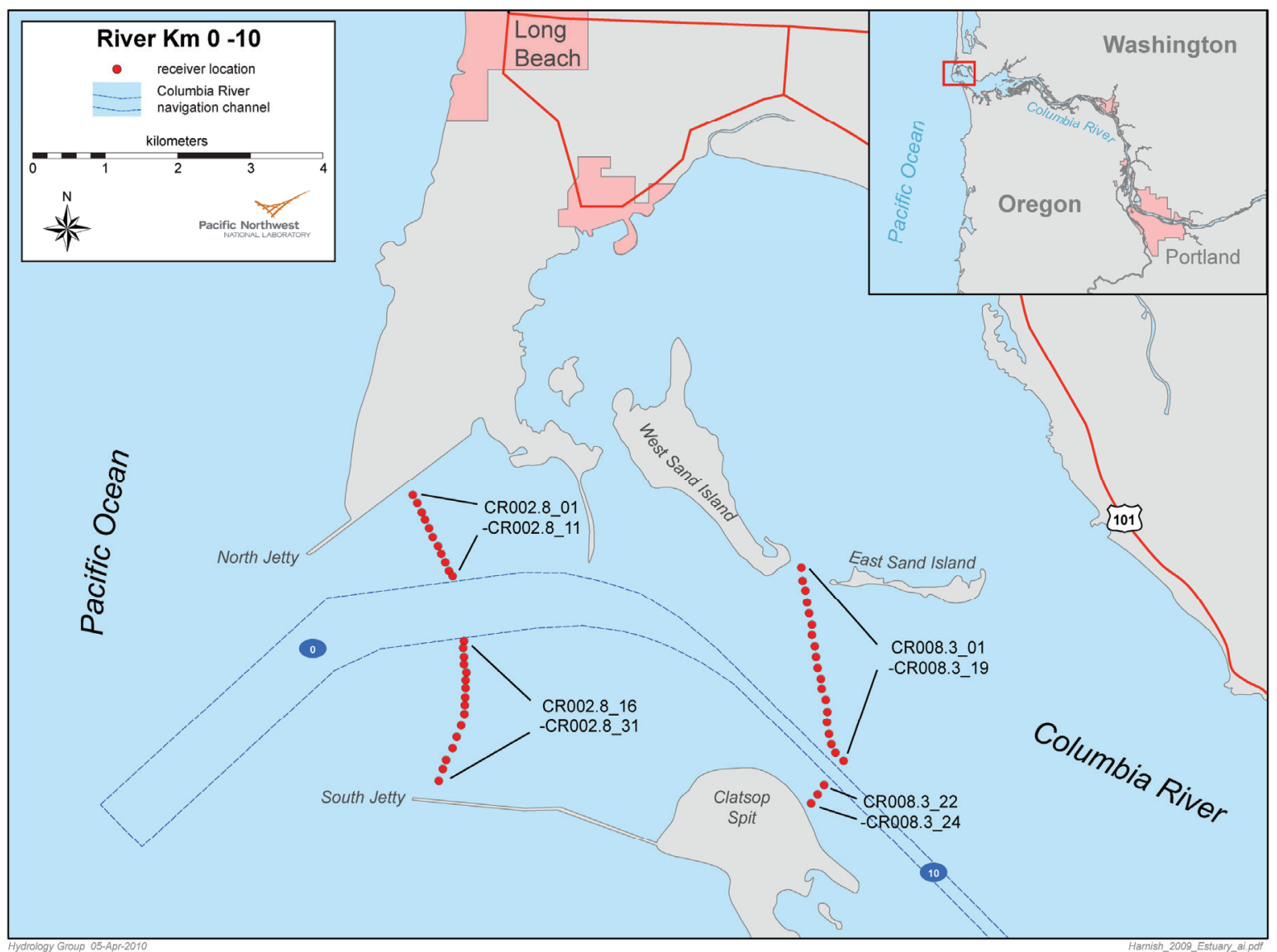

Figure 2.4. Locations of acoustic telemetry receiver arrays at East Sand Island (CR008.3) and the Columbia River Bar (CR002.8) in 2009.

Each receiver incorporated a single-point attachment to the mooring line (Figure 2.5). Receiver housings were fitted with a stainless steel band that held a 9.5 -mm-diameter nylon thimble incorporated into the upper end of the 0.9-m-long x 9.5-mm-diameter (Samson Tenex) buoy line (Figure 2.5). The thimble was secured to the stainless steel band by a stainless steel bolt, allowing the thimble to pivot freely along the axis of the receiver body. The lower end of the buoy line was attached to the upper end of an acoustic release (10.2 cm in diameter x $84 \mathrm{~cm}$ long; Model 111, InterOcean Systems, Inc., San Diego, California). Extra buoyancy was added between the receiver and release with three yellow Bao Long buoys (12.4 cm in diameter x $16.5 \mathrm{~cm}$ long, with $1.45 \mathrm{~kg}$ buoyancy each; Bao Long Industrial Ltd., Taiwan, Republic of China) threaded onto the buoy line. The lower end (releasing end) of the release held a 10-cm-diameter galvanized steel ring that was incorporated into the upper end of a shockcorded mooring (anchor line) made from 9.5-mm-diameter Samson Tenex line. The length of this line was dependent on water depth at the deployment location. In areas greater than $12 \mathrm{~m}$ deep, a 3.7-m anchor line was used. In areas less than $12 \mathrm{~m}$ deep, a 1.5-m anchor line was used. The lower end of the anchor line was terminated by a $9.5-\mathrm{mm}$ nylon thimble attached to a $68-\mathrm{kg}$ or $34-\mathrm{kg}$ steel anchor by a galvanized carbon steel shackle. Anchor design and size were determined by the deployment environment. In areas of low velocities $(<2 \mathrm{~m} / \mathrm{s})$, a 34-kg brick-style anchor was used; in areas of high velocities $(>2 \mathrm{~m} / \mathrm{s})$, a $68-\mathrm{kg}$ disk anchor was used. For more detail on receiver mooring and deployment methods, see Titzler et al. (2010). 

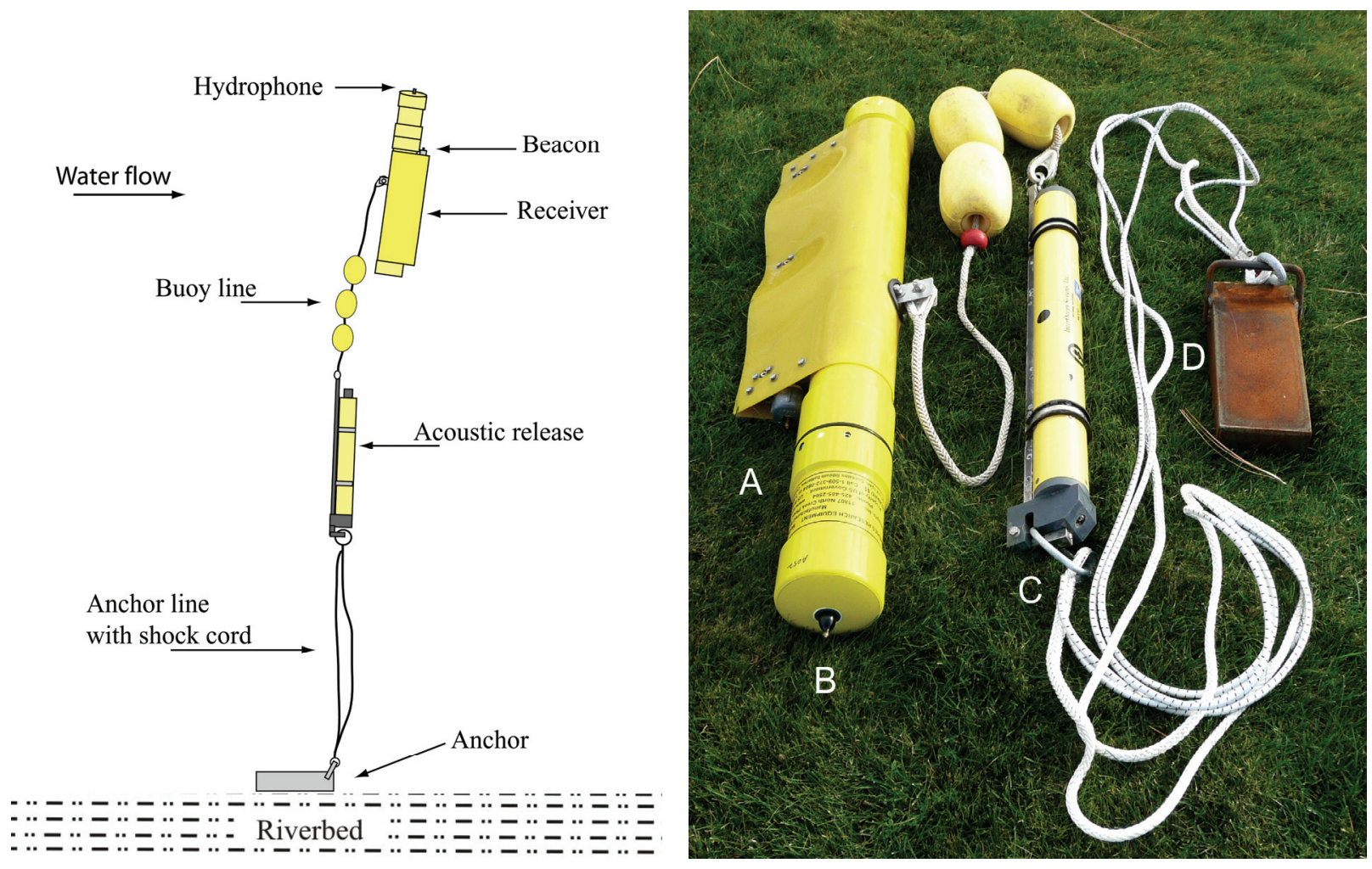

Figure 2.5. The JSATS autonomous acoustic receiver (A), hydrophone (B), acoustic release (C), anchor (D), and mooring used in 2009

Modifications to the mooring design were made based also on water depth and substrate characteristics. For shallow water deployments $(<5 \mathrm{~m})$, the anchor line was removed and the acoustic release was attached directly to the handle of the anchor, or a $0.30-\mathrm{m}$-long anchor line was used with the release and/or buoy line tied parallel with the receiver. In areas where there was concern for mooring line failure (i.e., areas with substrate composed of angular basalt boulders), a 1.5-m-long by 4.75-mmdiameter wire cable was substituted for the nylon shock-cord anchor line.

\subsubsection{Receiver Deployment}

Receivers were deployed from a $10 \mathrm{~m}$ vessel individually or in transect arrangements (arrays) that met detection requirements for the study objectives. Locations (waypoints) for each receiver were determined prior to deployment. Waypoints were created using Fugawi navigation software (Northport Systems, Inc., Toronto, Canada) and navigated to using a Global Positioning System (GPS) receiver. Before each acoustic receiver was deployed, an examination was completed to ensure that all equipment and parts were present, operational, labeled, and documented properly. Once the research vessel was positioned as close as possible to the predetermined waypoint, the anchor and receiver assembly (receiver, acoustic release, and short buoy line section) was lowered to the river bottom. When the anchor reached bottom, receiver waypoint was recorded. Pertinent information recorded for each waypoint included the waypoint name, date, time, depth (from vessel sonar), receiver serial number, and acoustic release code. Additional detail on deployment of JSATS autonomous receivers is presented in Titzler et al. (2010). 


\subsubsection{Receiver Recovery}

To recover the receiver, Fugawi and the research vessel GPS receiver was used to navigate to an acoustic receiver waypoint. An InterOcean Model 1100E command control unit (direct-current-operated transponder interrogator and receiver) was used to transmit a unique acoustic signal to each release. This code signaled the release to open, allowing the positively buoyant receiver assembly to ascend to the surface. Occasionally the receiver and/or mooring became fouled, preventing the receiver assembly from detaching from the anchor when the acoustic release was activated. When this happened, alternative methods were used to retrieve the receiver. In most cases, a grappling hook or pinch bar was dragged in an effort to snag the anchor or receiver assembly and lift them to the surface. To minimize data loss due to temporary absence of a receiver during the recovery-redeployment sequence, previously activated receivers were deployed immediately (typically within 5 minutes) following the recovery of each receiver.

\subsubsection{Receiver Servicing}

Receivers in the lower Columbia River (rkm 113.0 to 2.8) and estuary were serviced every 28-30 days. Recovered receivers were transported to a land-based research trailer to be serviced prior to redeployment. Servicing procedures included data recovery, damage inspection, installation of new batteries, performance tests, and receiver reactivation. If damage was discovered (e.g., cracked receiver housing) or the receiver failed the performance tests, the receiver was not redeployed.

\subsection{Autonomous Receiver Data Processing and Validation}

Signals received by JSATS autonomous receivers were processed and filtered to validate the presence of a tagged fish within the vicinity of a receiver at a specific time. Autonomous receivers recorded receptions of possible tag signals along with a timestamp for each reception. Raw files were timecorrected and filtered to remove spurious receptions prior to analysis of survival, travel time, or other aspect of fish behavior. The time series of validated locations for individual fish were then used to estimate survival rates and passage characteristics, such as travel times. A laboratory study of tag life was conducted to allow estimates to be corrected for early tag failures if necessary.

\subsubsection{Time Correction}

Receiving nodes used in this study were subject to clock errors that resulted in timestamps being incorrect at unpredictable times throughout the file. Raw files were processed through a time correction application to repair incorrect timestamps based upon correct timestamps that preceded it. In many cases, the algorithm precisely identified a correction that was accurate to the second, whereas in others, the correction resulted in a difference of a few seconds for the block of data being corrected. The criteria for acceptance of a time-corrected file required that the time at the end of the file be within one hour of the correct time (relative to the time of node recovery). A file that failed to meet these criteria would be evaluated further to see if an improvement could be made to meet the criteria. Since the receivers were serviced about once a month, a file typically contained 30 days of timestamps, so that one hour represented approximately $1 / 10$ th of one percent of the total time. In practice, not all files require time correction and most that do differ by much less than one hour following correction. Following time correction, files are referred to as time-corrected files, whether or not a correction was needed and applied. 


\subsubsection{Filtering}

Because receivers are configured to detect tag signals just above the acoustic noise floor, raw files often include spurious receptions that arise from noise, rather than a tag signal. To improve the effective signal-to-noise ratio, spurious receptions were identified and removed in a process known as filtering. In the filtering step, time-corrected files were processed to validate the presence of individual tags based on the time series of tag code receptions. Filtering algorithms take advantage of the fact that spurious receptions do not exhibit the temporal consistency among pulses that is characteristic of an actively transmitting JSATS tag.

The nominal ping rate interval (PRI) of each tag was known, but the actual PRI of a nominally 3 -second tag, for example, may be a few percent above or below the nominal value, and it may vary slightly through time with changes in battery voltage and temperature. This variation required that PRI be estimated at each point in time. After the PRI was estimated for a given starting reception, the estimate was used to develop a set of expected reception times to accept or reject individual receptions based upon when they were received. If enough hits were accepted within a short period of time following the initial reception, then the detections were deemed valid and were coded with an event number and output to a file. The processing steps follow below.

For each reception of a tag code:

1. Select the set of receptions of the same code within 15 PRIs after the initial reception.

2. Estimate the actual PRI from the timing of receptions following the initial reception

3. Accept only receptions that fall within a narrow window around each whole interval of the estimated PRI. If multiple receptions fall within the acceptance window, retain only the reception that most closely matches the estimated PRI.

4. If four or more hits are accepted within 12 estimated PRIs from the initial reception, mark accepted receptions as belonging to a valid detection event.

5. Repeat the steps above for each hit in the file to identify all valid detection events for all tag codes.

6. If multiple valid detection events for a single tag code overlap in time, combine them into a single valid detection event.

7. Output the set of valid detection events.

When combined with information on receiving node location, the set of valid detection events for a given tag code comprised a time series of locations for the fish implanted with that tag. This data provides the foundation for estimating various measures of the performance of fish migrating through the lower Columbia River, such as survival rates, travel times, and distributions.

\subsection{Route Assignments}

Cabled dam-face receivers were used together with PIT detections in the juvenile bypass systems (at both dams) and corner collector (at Bonneville Dam) to assign dam passage routes to acoustic-tagged yearling and subyearling Chinook salmon and steelhead as part of the "Studies of Surface Spill at John 
Day Dam" (U.S. Army Corps of Engineers Study Code SPE-P-08-03) and "Passage Behavior and Survival of Juvenile Salmonids at Bonneville Dam" (U.S. Army Corps of Engineers Study Code SPE-P-10-1).

Cabled arrays were deployed along the entire upstream face of John Day Dam and the entire upstream face of Bonneville Dam Powerhouse 2 to detect approaching JSATS-tagged smolts. Multiple hydrophones were deployed at different depths on each main pier. Additional hydrophones were attached to clump mounts and lowered to the bottom of the forebay directly upstream of the dam face to provide additional detections off of the plane of the dam face to increase the resolution of three-dimensional (3D) tracking.

Filtering algorithms were applied to the raw results from the decoding utilities to exclude spurious data and false positives. Valid detections were used to track the movement of fish in 3D based on differences in the time of arrival of the acoustic signal among different hydrophones. Tracks were used to assign fish to a passage route. All possible passage routes were monitored at John Day Dam, including juvenile bypass system, deep spill, shallow spill through the temporary spillway weir (TSW), and turbine passage. The TSW was only operated during spring and was not a possible passage route for subyearling Chinook salmon. Because only Powerhouse 2 was monitored at Bonneville Dam, only fish that passed through the corner collector, juvenile bypass system, or Powerhouse 2 turbines were assigned routes.

\subsection{Tag Life}

For the tag life study, 89 acoustic tags (3-s ping rate) were randomly chosen from two manufacturing batches of ATS tags delivered for implantation in fish at John Day Dam. The tags were divided into two groups of nearly equal numbers and tag life was monitored separately for each group. Data from both manufacturing batches were pooled for analysis. All acoustic tags were enclosed in water-filled plastic bags and suspended from a rotating foam ring within a $2 \mathrm{~m}$ (diameter) fiberglass tank. Two $90^{\circ} \times 180^{\circ}$ hydrophones were positioned $90^{\circ}$ apart in the bottom of the tank and angled upward at approximately $60^{\circ}$ to maximize coverage for detecting acoustic signals. Hydrophones were cabled to a quad-channel receiver that amplified all acoustic signals. All acoustic signals were then saved, decoded, and postprocessed. Post-processing software calculated the number of hourly decodes for each acoustic tag, and therefore tag failure times could be determined within $\pm 1 \mathrm{~h}$. Tag life expectancy was $23 \mathrm{~d}$ for all acoustic tags in this study (Appendix C).

\subsection{Survival Estimation}

Survival estimates were derived from conventional statistical models for mark-recapture data from a single group of marked animals (Cormack 1964; Jolly 1964; Seber 1965). This model is known by various names, including Cormack-Jolly-Seber (CJS) Model and Single-Release (SR) Model. The model is simple when there are only two detection opportunities for each marked animal. For purposes of survival estimation, detection data are summarized as the "detection history" for each marked fish. With only two opportunities for detection, the possible detection histories for tagged fish are

- 00 - never detected

- 10 - detected on the upstream, or primary, array but not on the downstream, or secondary, array

- 01 - detected on the downstream (secondary) array but not on the upstream (primary) array

- 11 - detected on both arrays. 
To estimate survival to the primary array for a release group of tagged fish, the number of fish in the group with each detection history is determined, denoted $\mathrm{n} 00, \mathrm{n} 01, \mathrm{n} 10$, and $\mathrm{n} 11$, along with the total number of fish released, denoted $\mathrm{R}$.

The proportion of fish detected on the primary array $[(\mathrm{n} 10+\mathrm{n} 11) / \mathrm{R}]$ is an estimate of the joint probability that a fish survived from release to the primary array $(\mathrm{S})$ and that the fish was detected given that it survived (P). Assuming that survival to the primary array and detection on that array are independent events; the joint probability of both events occurring is the simple product of the two probabilities. Thus, the proportion detected on the primary array is an estimate of SP.

To separate the two probabilities in the product requires a method to estimate either of the probabilities individually. The remaining probability can then be estimated by dividing the joint estimate by the estimate of the first. Detection probability on the primary array can be estimated independently by assuming that fish that survived to the secondary array and were detected there $(\mathrm{n} 01+\mathrm{n} 11)$ represent a random sample of all fish from the group that were alive as they passed the primary array. Detection probability on the primary array is then estimated as the proportion of the sample detected on the primary array $[\mathrm{n} 11 /(\mathrm{n} 01+\mathrm{n} 11)]$.

Survival between the primary and secondary arrays cannot be estimated separately from the detection probability on the secondary array, because without a third detection opportunity there is no way to construct the sample from which to estimate detection separately. Thus, we can estimate only the joint probability of surviving between the two arrays and being detected on the secondary array.

Survival was estimated from the virtual release location in the Bonneville Dam forebay (CR236.0) to each receiver array downstream to the East Sand Island array (CR008.3) for all yearling and subyearling Chinook salmon and steelhead pooled and for each virtual release group. Virtual release groups were formed in the Bonneville Dam forebay by week of detection at the CR236.0 array. A virtual release is the formation of a group of fish based on their detections on a specific receiver array during a specific time period, independent of when or where they were released (Buchanan et al. 2009; Skalski et al. 2009). Only fish detected at CR236.0 were included in survival analyses. Limiting the analyses to fish detected at CR236.0 provided a common location, or starting point, for temporal grouping of fish by week of detection at the virtual release location. Survival was also estimated for each river reach located between the receiver arrays downstream to CR008.3. Reach survival estimates were calculated for yearling and subyearling Chinook salmon and steelhead by forming a virtual release of all fish detected by the array located at the upstream boundary of the reach. For each survival estimate, detections at all downstream arrays were pooled to develop the detection history of the secondary array. That is, if a fish was detected at any of the arrays downstream of the array to which survival was being estimated, the fish was assigned a " 1 " in the detection history for the secondary array.

Because the distance between receiver arrays was not equal it was desirable to have a measure of reach survival that was independent of the distance over which it was estimated. Therefore, survival per river kilometer was estimated from each reach survival estimate by: 


$$
S_{k m}=S_{\text {reach }}^{1 / L}
$$

where

$$
\begin{aligned}
& S_{k m}=\text { estimate of survival per river kilometer, } \\
& S_{\text {reach }}=\text { reach survival estimate, and } \\
& L \quad=\text { reach length in river kilometers. }
\end{aligned}
$$

\subsubsection{Survival by Dam Passage Route}

Dam passage routes at John Day Dam and Bonneville Dam Powerhouse 2 were assigned to JSATStagged yearling and subyearling Chinook salmon and steelhead as part of studies SPE-P-08-03 and SPE-P-10-1. To determine if there is any latent mortality associated with passage through specific routes at these dams, survival was estimated from the Lady Island array (CR192.0) to the East Sand Island array (CR008.2) for every possible combination of monitored passage routes for which 20 or more fish were assigned. Likelihood-ratio tests were performed within Program MARK to test whether survival probability estimates differed $(\alpha=0.05)$ between combinations of monitored passage routes.

\subsubsection{Burnham Tests of Survival Model Assumptions}

A major assumption of the CJS SR survival model used in this study is that upstream detections do not affect downstream detection or survival probabilities. Burnham et al. (1987) present a series of tests of assumptions of the CJS SR model called Test 2 and Test 3. Test 2 examines whether or not a fish is detected at an array affects the probability of detection at the next downstream array. Test 3 examines whether upstream capture histories affect downstream survival and/or detection. Contingency table tests were performed for Test 2 and Test 3 for each virtual release group of yearling and subyearling Chinook salmon and steelhead at each array of acoustic telemetry receivers. Chi-square tests $(\alpha=0.05)$ were performed on each contingency table when all numbers in the table were $\geq 10$. Fisher's exact test $(\alpha=0.05)$ was used when any number in the contingency table was $<10$.

\subsection{Migration Behavior}

\subsubsection{Travel Time}

Travel time was calculated for yearling and subyearling Chinook salmon and steelhead in the following reaches: Bonneville Dam forebay array (CR236.0) to the East Sand Island array (CR008.3), CR236.0 to the Lady Island array (CR192.0), CR192.0 to the Cottonwood Island array (CR113.0), CR113.0 to the Oak Point array (CR086.2), CR086.2 to the Three Tree Point array (CR049.6), CR049.6 to the Astoria Bridge array (CR022.0), and CR022.0 to CR008.3. Travel time was calculated for each fish detected at both the upstream and downstream arrays by subtracting the date and time of first detection at the upstream array from the date and time of first detection at the downstream array. Travel rate was calculated from each travel time by dividing the travel time by the distance between the arrays. Because calculation of travel time requires detection at both the upstream and downstream arrays, estimates of travel time and travel rate only consider fish that successfully migrated through the entire reach. 


\subsubsection{Migration Pathways}

Valid detections from receivers located at Harrington Point (CR037.3) and downstream were analyzed to determine the migration pathways, survival, and travel time of fish from Harrington Point to the receiver array located at the Astoria Bridge (CR022.0). The primary migration pathways used by fish to travel from Harrington Point to the Astoria Bridge were determined by grouping fish by the Harrington Point receiver at which they were last detected (CR037.3_01, CR037.3_02, CR037.3_03, or CR037.3 04), then calculating the proportion of fish from each of these groups that were first detected at the Astoria Bridge array in the Washington channel (CR022.0_01-10), mid channel (CR022.0_11), or in the Oregon channel (CR022.0_12-17). The proportion of fish from each group that was detected in Grays Bay (CR034.0 and CR029.3) was also calculated. Proportions were converted to percentages for presentation in the results section. Travel times were calculated for each group by subtracting the date and time of first detection at the Astoria Bridge array from the date and time of last detection at the Harrington Point array. Survival probability estimates were calculated for each group of fish using the CJS SR model applied by Program SURPH. The Harrington Point receiver of last detection was used as the virtual release location for calculating survival probability estimates to the initial 'capture' location at the Astoria Bridge array. Detections at downstream arrays (CR008.3 and CR002.8) were used as the secondary 'recapture' event. Survival was also estimated from the Grays Bay receivers to the Astoria Bridge array.

Travel times were analyzed to determine the effect of migration pathway on the amount of time Chinook salmon and steelhead smolts took to migrate through the Columbia River estuary. The ShapiroWilk normality test $(\alpha=0.05)$ was used to test for normality of travel time data. Because travel time data frequently deviated from the normal distribution, being right-skewed, median travel times were calculated for each fish group of interest and non-parametric statistics were used. The Kruskal-Wallis one-way analysis of variance by ranks test $(\alpha=0.05)$ was used to determine if differences in travel times existed within species or run type for fish that migrated through different pathways. If a significant difference was detected, pair wise comparisons were made using the Mann-Whitney-Wilcoxon test $(\alpha=0.05)$ to determine which two groups differed significantly.

Survival probability estimates were analyzed to determine the effect of migration pathway on survival of Chinook salmon and steelhead smolts in the Columbia River estuary. Likelihood-ratio tests were performed within Program MARK to test whether survival probability estimates differed $(\alpha=0.05)$ within each species or run type for fish that migrated through different pathways.

\subsubsection{Cross-Channel Distribution}

The cross channel-distribution of fish detections were analyzed for each species and run type at the Astoria Bridge (CR022.0), East Sand Island (CR008.3), and Columbia River Bar (CR002.8) arrays. First, a reference point was plotted on the southern shore at each array, and the distance from the reference point to each receiver location was calculated using the Pythagorean theorem. Receivers separated by less than $0.1 \mathrm{~km}$ were grouped as a single receiver location. Tables of locations and distances for receivers of each array can be found in Appendix G. The cross-channel distribution of each species and run type was calculated by dividing the number of fish first detected at each receiver location by the total number of fish from that species or run type detected on the array. This proportion was multiplied by 100 
for presentation as a percentage in the results section. Percentages were then plotted against the calculated distance from the reference points at each array.

\subsubsection{Diel Distribution}

The diel distribution of fish detections were determined for yearling and subyearling Chinook salmon and steelhead at the Three Tree Point (CR049.6), Harrington Point (CR037.3), Astoria Bridge (CR022.0), East Sand Island (CR008.3), and Columbia River Bar (CR002.8) arrays. For each group of fish, the number of fish first detected during each hour at a particular array was divided by the total number of fish from that group detected at that array. This proportion was multiplied by 100 for presentation as a percentage in the results section. Plots of the percentage of fish detected each hour were created for each group of fish at each array. Bars indicating approximate hours of darkness were placed beginning one hour after sunset and ending one hour before sunrise. Average sunrise and sunset times were calculated from the sunrise and sunset times of the first and last day of detection for each group of fish, based on data downloaded from the U.S. Naval Observatory website for Astoria, Oregon (available at http://www.usno.navy.mil/USNO/astronomical-applications/data-services/rs-one-year-us).

\subsubsection{Diel Distribution with Tide Stage}

Fish were split into virtual release groups based on date of first detection at the Bonneville Dam forebay array (CR236.0). As above, the number of fish first detected during each hour at a particular array was divided by the total number of fish from that group detected at that array, multiplied by 100 , and plots of the percentage of fish from each group detected each hour were created for the Astoria Bridge (CR022.0), East Sand Island (CR008.3) and Columbia River Bar (CR002.8) arrays. Estimates of tide stage in 5-minute increments were generated using the program WXTide32

(http://www.wxtide32.com/). The average tide stage was calculated at each array for each hour during the days in which the middle $80 \%$ of the fish from each virtual release were first detected at the arrays. Average tide stage was added to the plots of diel distribution. For example, assume 10 fish from a release group were detected at an array, with one fish detected per day from May 1 to May 10. The average tide stage each hour would be calculated for tides between May 2 and May 9. For array CR002.8, the tides were output for the station "Columbia River: Entrance, N. Jetty (t)". For arrays CR008.3 and CR022.0, the station "Columbia River: Chinook, Baker Bay (t)" was used.

\subsubsection{Tidal Influence}

Relationships between detections and tides were evaluated by assigning the first detection of each fish at the Three Tree Point (CR049.6), Harrington Point (CR037.3), Astoria Bridge (CR022.0), East Sand Island (CR008.3), and Columbia River Bar (CR002.8) arrays to a five-minute time window. Using the tide generating software WXTide32, tide elevation estimates were generated in five minute increments for periods during which tagged fish were migrating through the estuary. The station "Knappa, Knappa Slough, Columbia River, Oregon (t)" was used to determine the tide at array CR049.6, "Harrington Point, Columbia River, Washington (t)" was used for CR037.3, "Astoria (Port Docks), Columbia River, Oregon (t)" was used for CR022.0, "Columbia River: Chinook, Baker Bay (t)" was used for CR008.3, and "Columbia River: Entrance, N. jetty (t)" was used for CR002.8. The rate of change between each fiveminute period was then calculated, and associated with each of the fish detections. Rates of tide change were grouped into bins $(0.5 \mathrm{~cm} / 5 \mathrm{~min})$ and the percentage of first detections that fell into each bin was 
calculated. Percentages of detections of yearling and subyearling Chinook salmon and steelhead were plotted against the change in tide. The frequency of each tide change $(0.5 \mathrm{~cm} / 5 \mathrm{~min})$ was calculated during the time each species or run type was passing each array by dividing the number of tide changes in each bin that occurred between the first and last fish detections by the total number of tide changes $(0.5 \mathrm{~cm} / 5 \mathrm{~min})$ that occurred between the first and last detections.

\subsubsection{Avian Predation}

PIT tag detections of acoustic-tagged fish on the East Sand Island bird colonies were obtained from NOAA Fisheries. Detections were summarized by the colony on which the tags were detected (Caspian tern or double-crested cormorant), array (or receiver) of last detection, cross-channel distribution of detections, and by virtual release group for each species and run-type. Cross-channel distribution of fish whose tags were detected on the bird colonies was computed using a method similar to that described above for the cross-channel distribution of all fish. However, instead of using only the first detections of each fish at an array, first detections at each receiver in the array were used for each fish detected. Because fish may move laterally along an array, this method provides a better indication of which areas of an array are used most, as opposed to using only the location of first detection at an array. Areas where fish move laterally along an array could potentially expose fish to higher rates of avian predation than areas of an array where fish pass through directly. Because fish detected at more than one receiver location were counted at each location, percentages add to more than $100 \%$. Using this method for fish detected on the bird colonies and for the entire population of tagged fish detected at an array, crosschannel distributions were calculated and plotted on the same chart for each group of fish at each array. 



\subsection{Results}

\subsection{Environmental Conditions}

For the duration of the study, between deployment of the first acoustic receiver and recovery of the final receiver (April 25 to August 27), total daily discharge through Bonneville Dam ranged from 93 to $361 \mathrm{kcfs}$ with a mean of $216 \mathrm{kcfs}$. Discharge during the study period fluctuated above and below the 10-yr average, exhibiting higher than average peak flows in the spring season and lower than average flows in the latter portion of the summer; overall discharge in 2009 showed a similar seasonal trend to the 10-yr average (Figure 3.1).

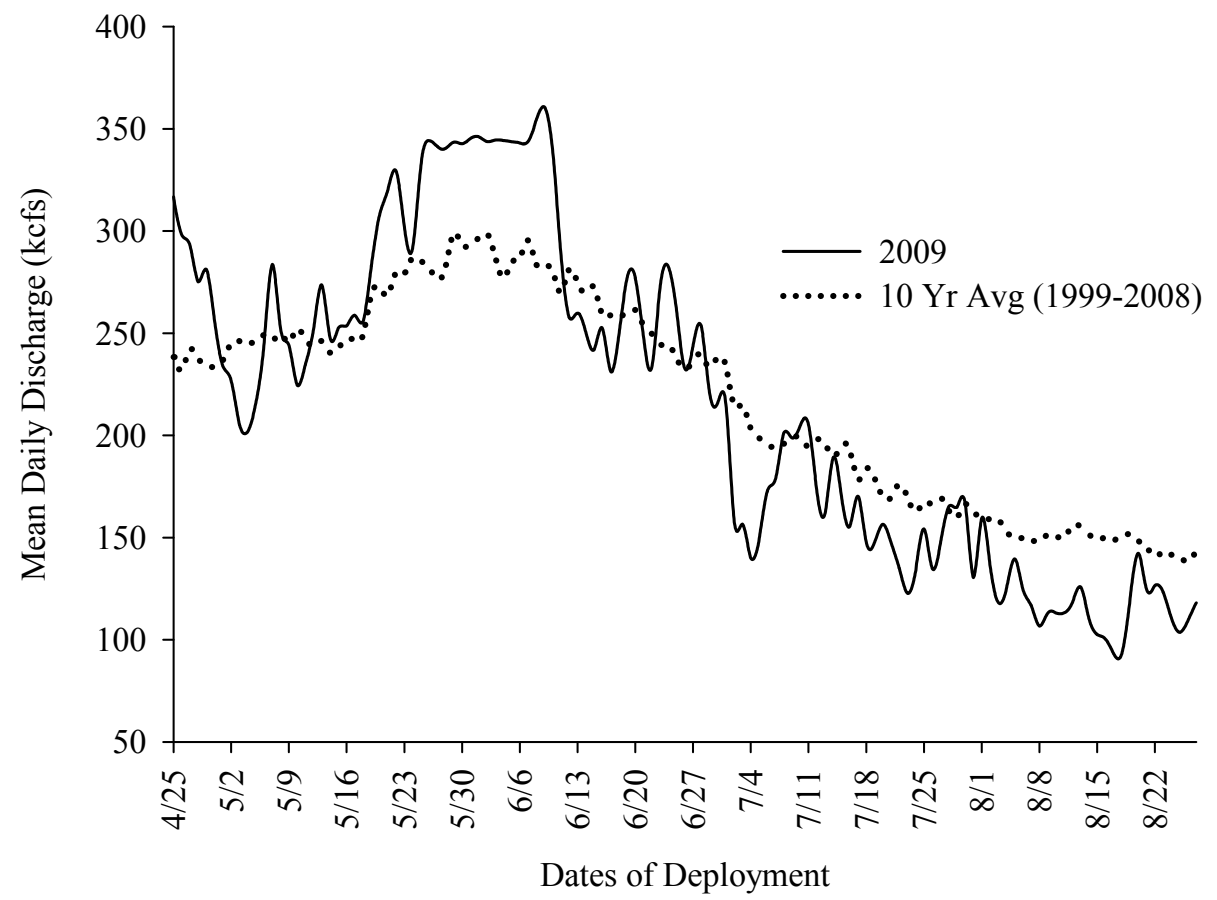

Figure 3.1. Average daily water discharge (kcfs) during the 2009 study period and the preceding $10-\mathrm{yr}$ average discharge from Bonneville Dam.

Daily water temperatures in the forebay of Bonneville Dam ranged for 9.9 to $23.6^{\circ} \mathrm{C}$ with a mean temperature of $17.1^{\circ} \mathrm{C}$. At the beginning of the spring study period, forebay water temperatures were below the 10-year average, but exhibited a temporal warming trend similar to that of the 10-year average. Peak summer temperatures in 2009 were higher than those of the 10-year average (Figure 3.2).

\subsection{Smolt Migration Timing and Fish Size}

The spring and summer tagging seasons corresponded well with the run timing of the general population at John Day Dam. The release of tagged fish was initiated during the spring season when about $9 \%$ and $5 \%$ of the general yearling Chinook salmon and steelhead populations, respectively, had passed John Day Dam (Figure 3.3). The releases of implanted yearling Chinook salmon and steelhead 


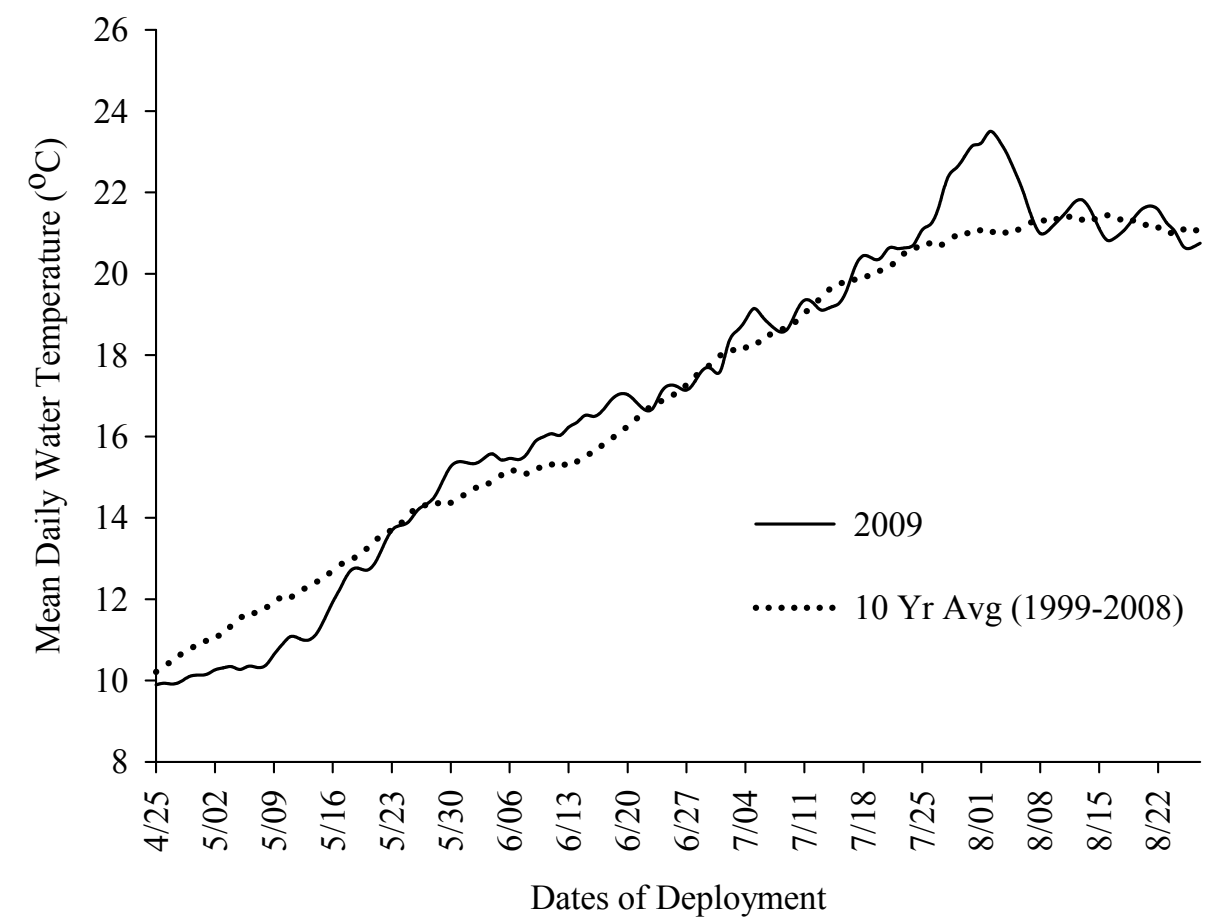

Figure 3.2. Average daily water temperature $\left({ }^{\circ} \mathrm{C}\right)$ in the Bonneville Dam forebay during the 2009 study period and the preceding 10-year average

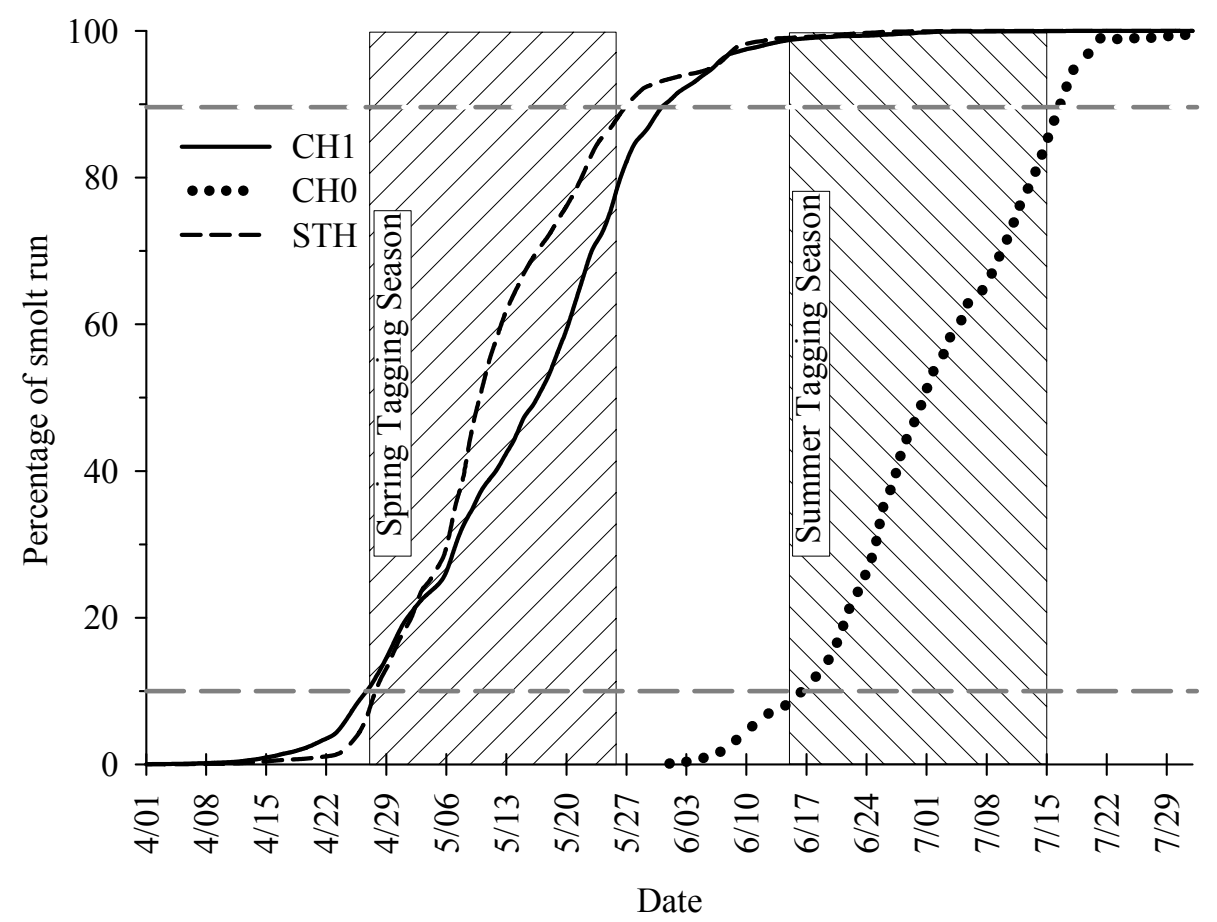

Figure 3.3. The percentage of yearling and subyearling Chinook salmon and steelhead smolts that emigrated passed John Day Dam and the timing of tagging operations in 2009. The middle $80 \%$ of the run $\left(10^{\text {th }}\right.$ to $90^{\text {th }}$ percentile $)$ for all species/stocks is shown. 
ended when about $79 \%$ and $88 \%$ of the general yearling Chinook salmon and steelhead populations, respectively, had passed John Day Dam. During the summer season, releases of tagged subyearling Chinook salmon began when about $9 \%$ of the general subyearling Chinook salmon population had passed John Day Dam and ended when about $85 \%$ of the general population had passed.

The timing and duration of sampling with acoustic receivers generally corresponded well with the run timing of yearling and subyearling Chinook salmon and steelhead at Bonneville Dam. The first deployment of acoustic receivers occurred when about $1 \%$ of the general steelhead population and about $16 \%$ of the general yearling Chinook salmon population passed Bonneville Dam. The final receiver was recovered after about $99 \%$ of the general subyearling Chinook salmon population passed Bonneville Dam (Figure 3.4).

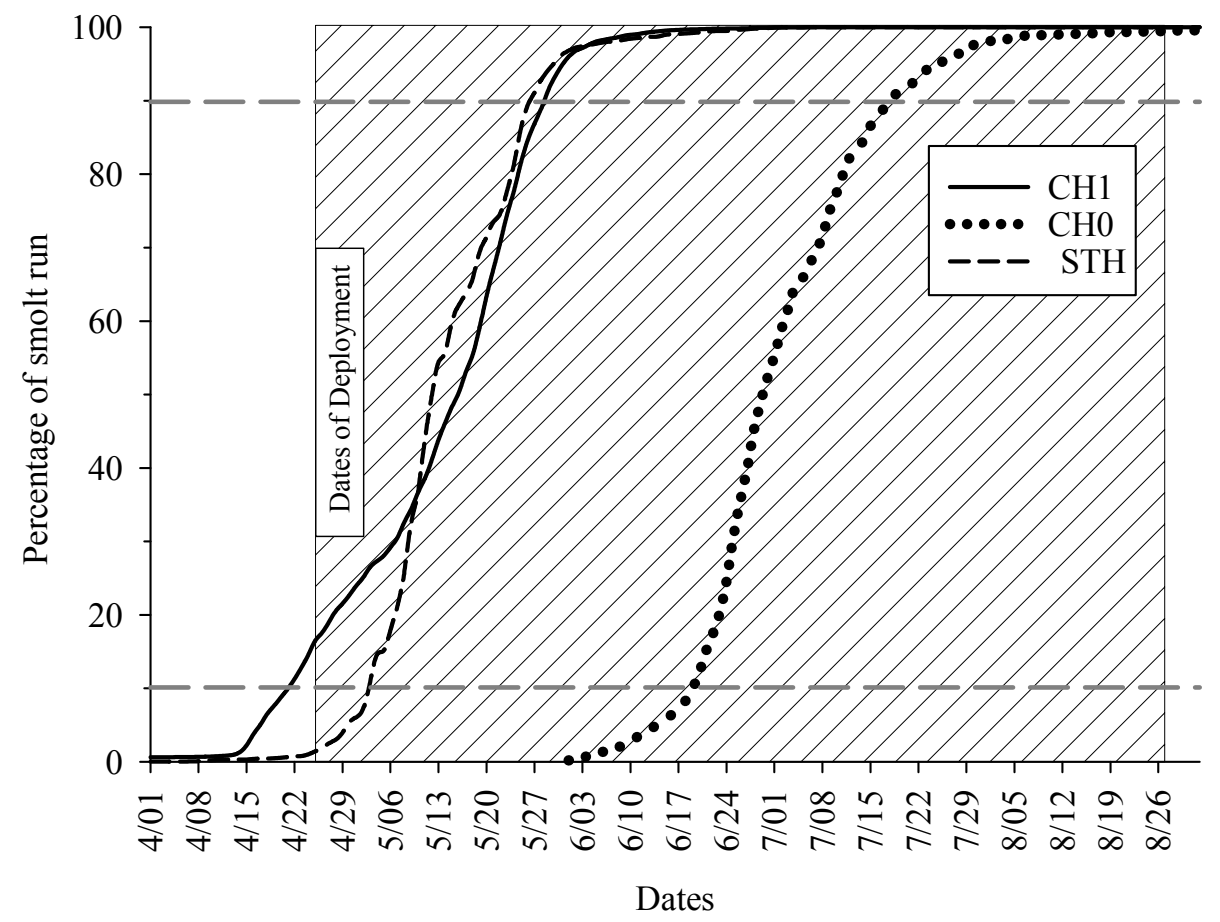

Figure 3.4. The percentage of yearling and subyearling Chinook salmon and steelhead smolts that passed Bonneville Dam by date. The middle $80 \%$ of the run (10th to 90 th percentile) for all species/stocks and the dates acoustic receivers were deployed in the Columbia River Estuary are shown.

The distributions of lengths of tagged yearling and subyearling Chinook salmon and steelhead were similar to those of the untagged populations as determined from the smolt monitoring program conducted at the SMF at John Day Dam (Figures 3.5, 3.6, and 3.7). Median lengths of tagged and untagged fish differed by just $2 \mathrm{~mm}$ for steelhead and yearling Chinook salmon smolts and by less than $3 \mathrm{~mm}$ for subyearling Chinook salmon smolts. 


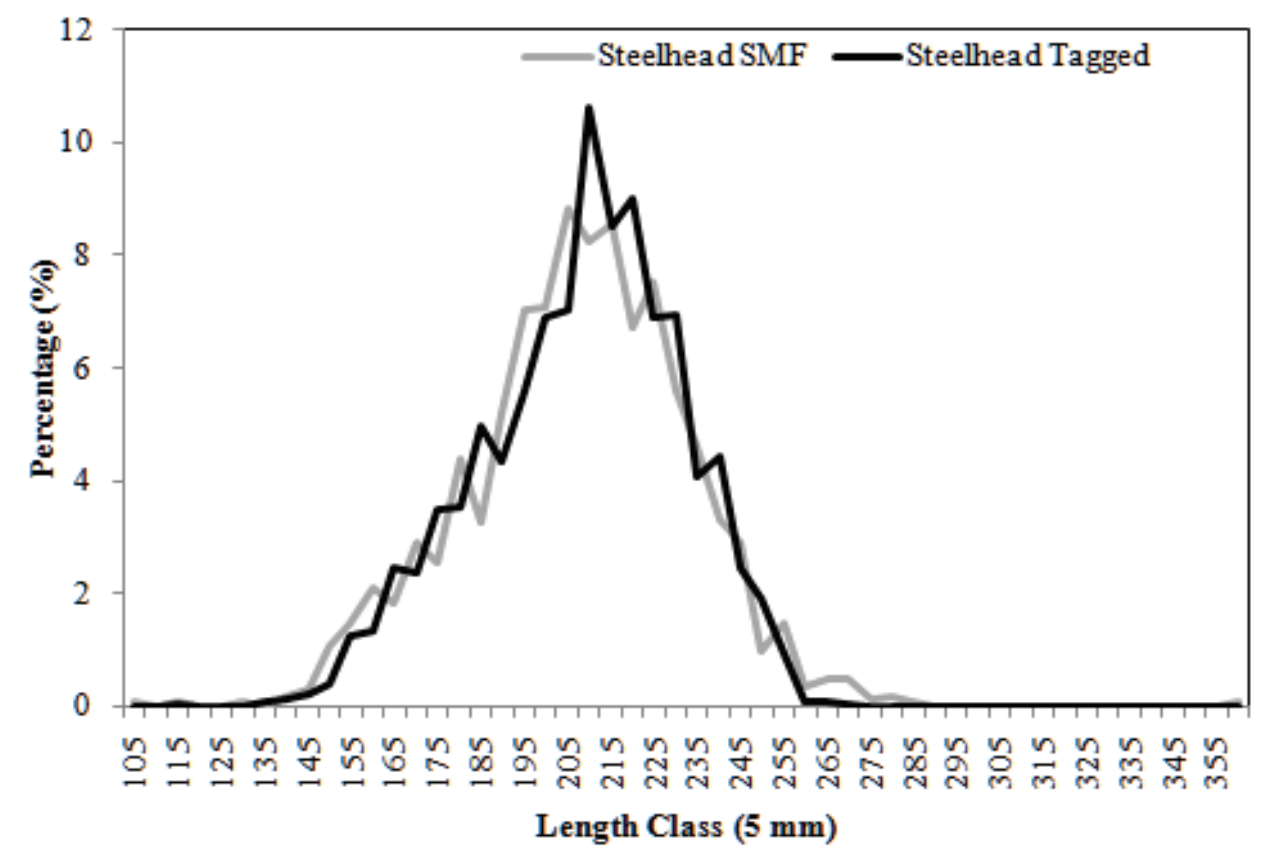

Figure 3.5. Length frequency distributions for tagged and untagged steelhead at JDA in 2009

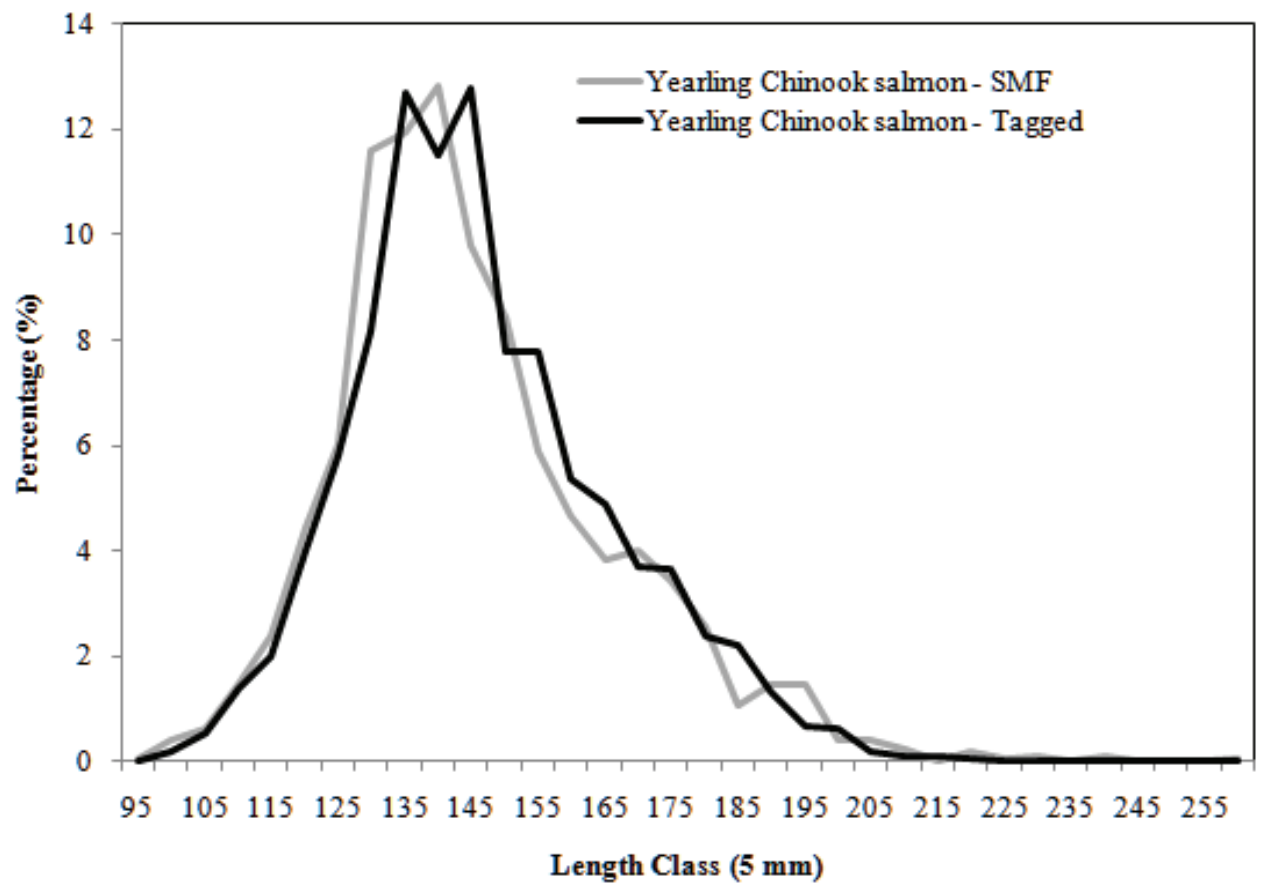

Figure 3.6. Length frequency distributions for tagged and untagged yearling Chinook salmon in 2009 


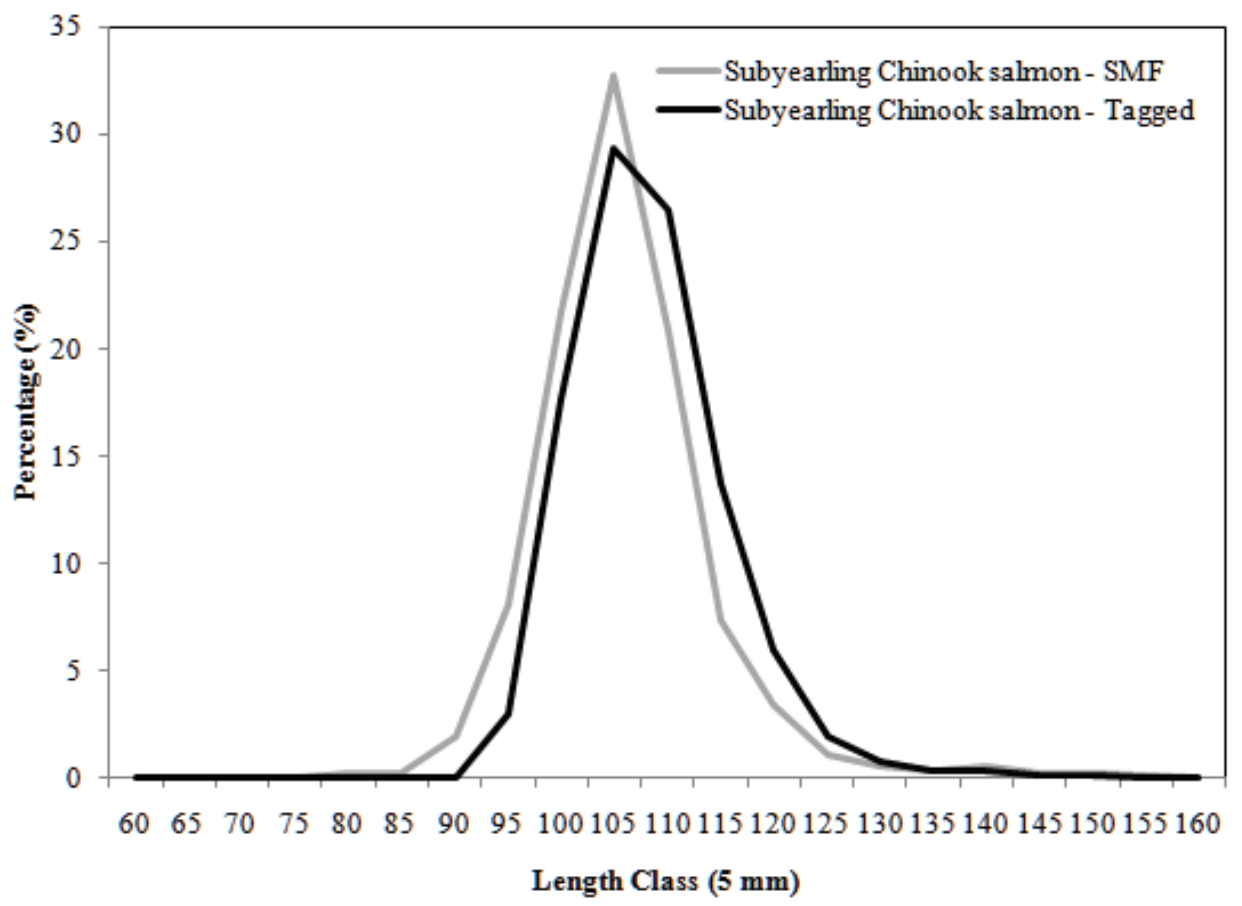

Figure 3.7. Length frequency distributions for tagged and untagged subyearling Chinook salmon in 2009

\subsection{JSATS Performance}

\subsubsection{Tag Life Studies}

All acoustic transmitters withheld for tag life studies remained active for at least 23 days, which was sufficient time for acoustic-tagged yearling and subyearling Chinook salmon and steelhead to migrate from the release site at Arlington, Oregon, to the mouth of the Columbia River (Figure 3.8). Over 99.5\% of the yearling and subyearling Chinook salmon and steelhead that were detected at the East Sand Island (CR008.3) and Columbia River Bar (CR002.8) arrays were detected within 23 days of their transmitter activation date. However, to better understand the influence tag life corrections (Appendix C; Townsend et al. 2006) may have had on survival estimates, we performed tag life corrections on 15 of the survival estimates (CR236.0 to CR008.3 for all 5 virtual release weeks of $\mathrm{CH} 1, \mathrm{CH}$, and STH) that would have been most likely to have been influenced by tag life.

\subsubsection{Array Detection Probability}

Detection probability varied by array, and for some arrays, by season (Appendix D, Table D.1). The overall detection probability (all virtual release groups pooled) of the Lady Island array (CR192.0) was relatively high $(\geq 0.90)$ for all species/stocks. However, considerable seasonal variation was observed in the detection probability of the CR192.0 array. Detection probability of the CR192.0 array declined for each successive virtual release of yearling Chinook salmon and steelhead and increased for each successive virtual release of subyearling Chinook salmon. This trend was explained by the negative relationship between CR192.0 detection probability and discharge (Figure 3.9). Detection probability of CR192.0 declined sharply at high discharges (> $300 \mathrm{kcfs}$ ), which occurred during spring 2009. 


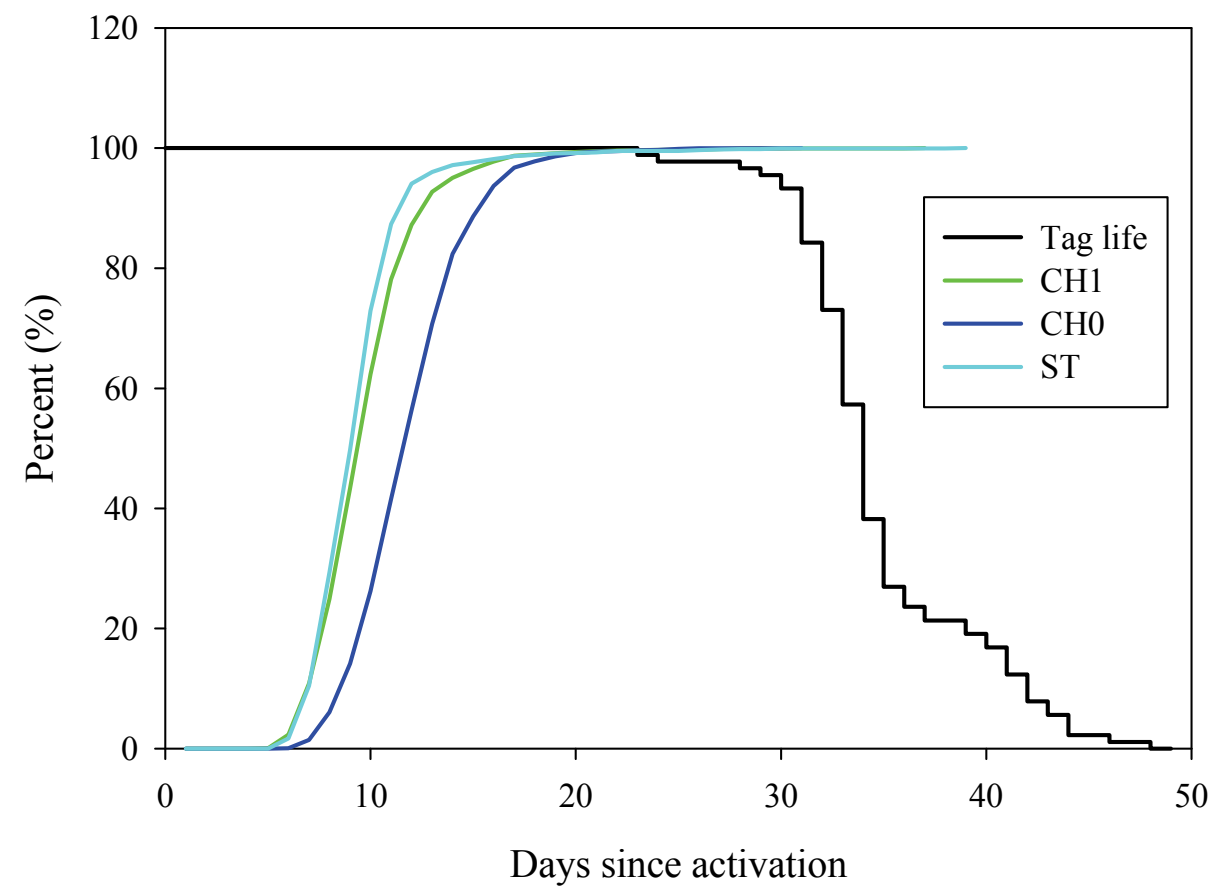

Figure 3.8. Percentage of acoustic transmitters still active by days since activation (tag life) and the percentage of yearling Chinook salmon $(\mathrm{CH} 1)$, subyearling Chinook salmon $(\mathrm{CH} 0)$, and steelhead (ST) first detections at the mouth of the Columbia River (arrays CR008.3 and CR002.8) by days since tag activation. Note: fish were released upstream of John Day Dam, therefore this is not illustrative of travel times between Bonneville Dam and the mouth of the Columbia River.

The overall detection probability of the Cottonwood Island array (CR113.0) was high and similar for all species/stocks (0.92 to 0.94; Table D.2). Detection probability of the CR113.0 array showed relatively little temporal variation (Figure 3.9). The overall detection probability of the Oak Point array (CR086.2) was also relatively high $(\geq 0.87)$ for all species/stocks (Table D.2). Seasonal trends of CR086.2 detection probability followed those of CR192.0, with detection probability declining as the spring season progressed, followed by increasing detection probability during summer. Again, this trend was partially explained by a negative relationship between detection probability and discharge (Figure 3.9). However, differences in detection probability of the CR086.2 array at around $300 \mathrm{kcfs}$ between spring and summer indicate that there may be fish behavior or seasonal effects on detection probability. Overall detection probabilities of the Three Tree Point (CR049.6) and Harrington Point (CR037.3) arrays were relatively low $(\leq 0.57)$ for all species/stocks (Table D.2). Relatively large seasonal differences in detection probability were observed at these arrays with detection probability increasing with increasing discharge at the CR049.6 array (Figure 3.10). The overall detection probability of the Astoria Bridge array $(\mathrm{CR} 022.0)$ was $0.74(\mathrm{SE}=0.01)$ for yearling Chinook salmon, $0.68(0.01)$ for subyearling Chinook salmon, and 0.76 (0.01) for steelhead (Table D.2). Detection probability of the CR022.0 array varied by less than $10 \%$ across all seasons and did not appear to be influenced by discharge (Figure 3.11). The detection probability of the East Sand Island array (CR008.3) was relatively high ( $\geq 0.84$ ) overall for all species/stocks, varied relatively little by season, and was not influenced by discharge (Figure 3.11). 

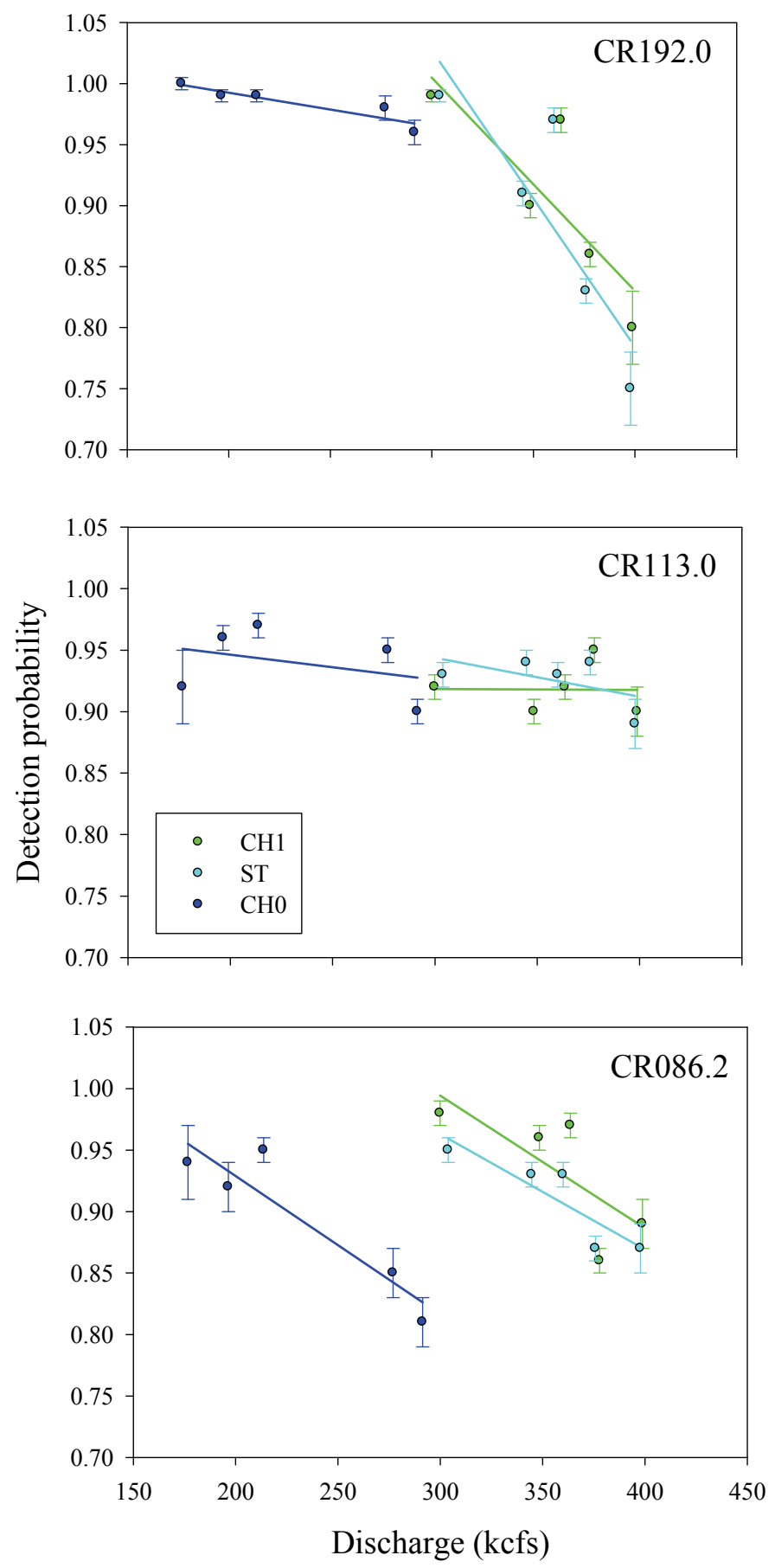

Figure 3.9. Detection probability of arrays at Lady Island (CR192.0), Cottonwood Island (CR113.0), and Oak Point (CR086.2) for each virtual release group of yearling Chinook salmon (CH1), steelhead (ST), and subyearling Chinook salmon ( $\mathrm{CH} 0)$ versus Columbia River discharge measured near Oak Point (rkm 86). Error bars denote one standard error. 


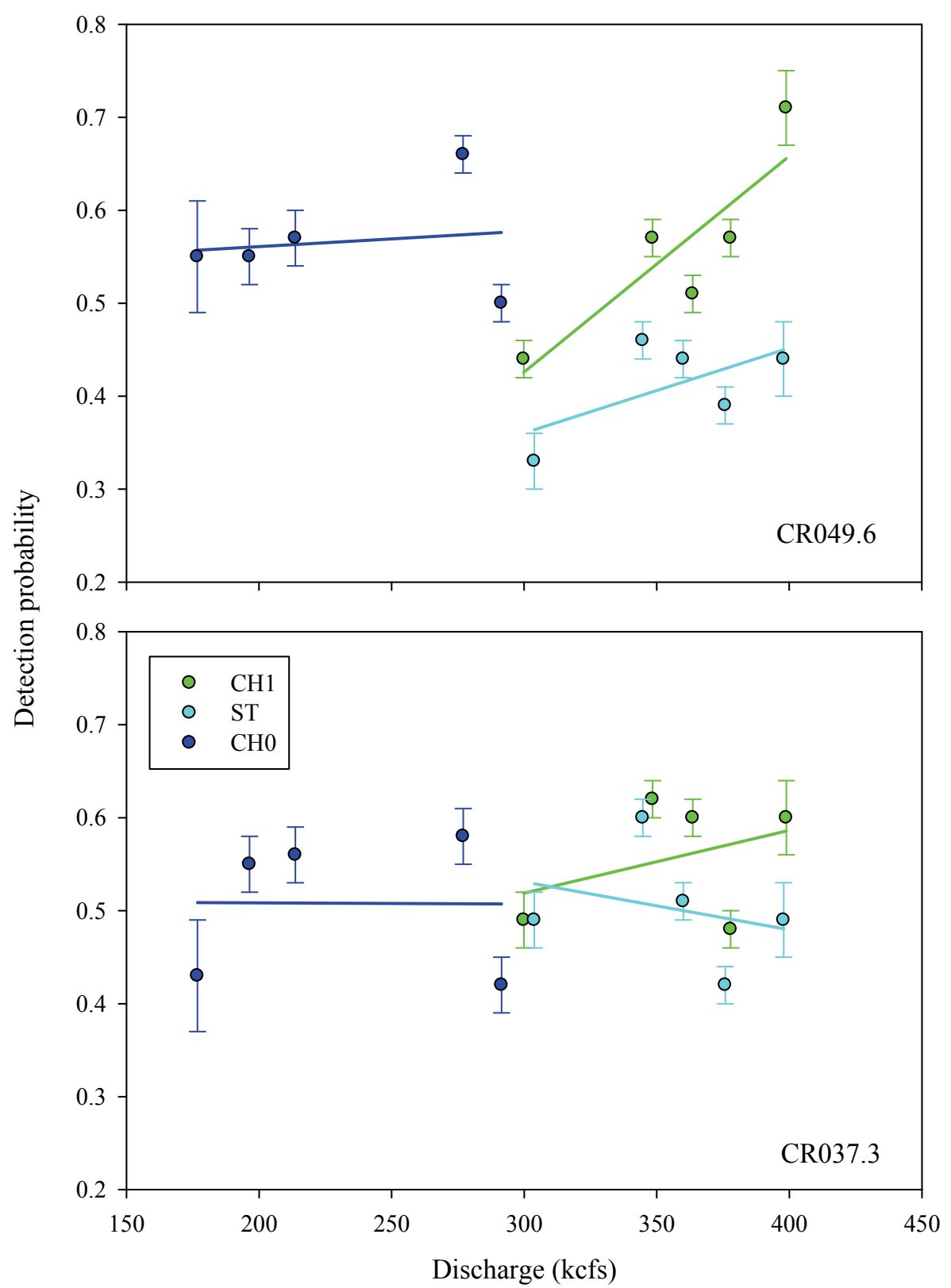

Figure 3.10. Detection probability of arrays at Three Tree Point (CR049.6) and Harrington Point (CR037.3) for each virtual release group of yearling Chinook salmon (CH1), steelhead (ST), and subyearling Chinook salmon (CH0) versus Columbia River discharge measured near Oak Point (rkm 86). Error bars denote one standard error. 


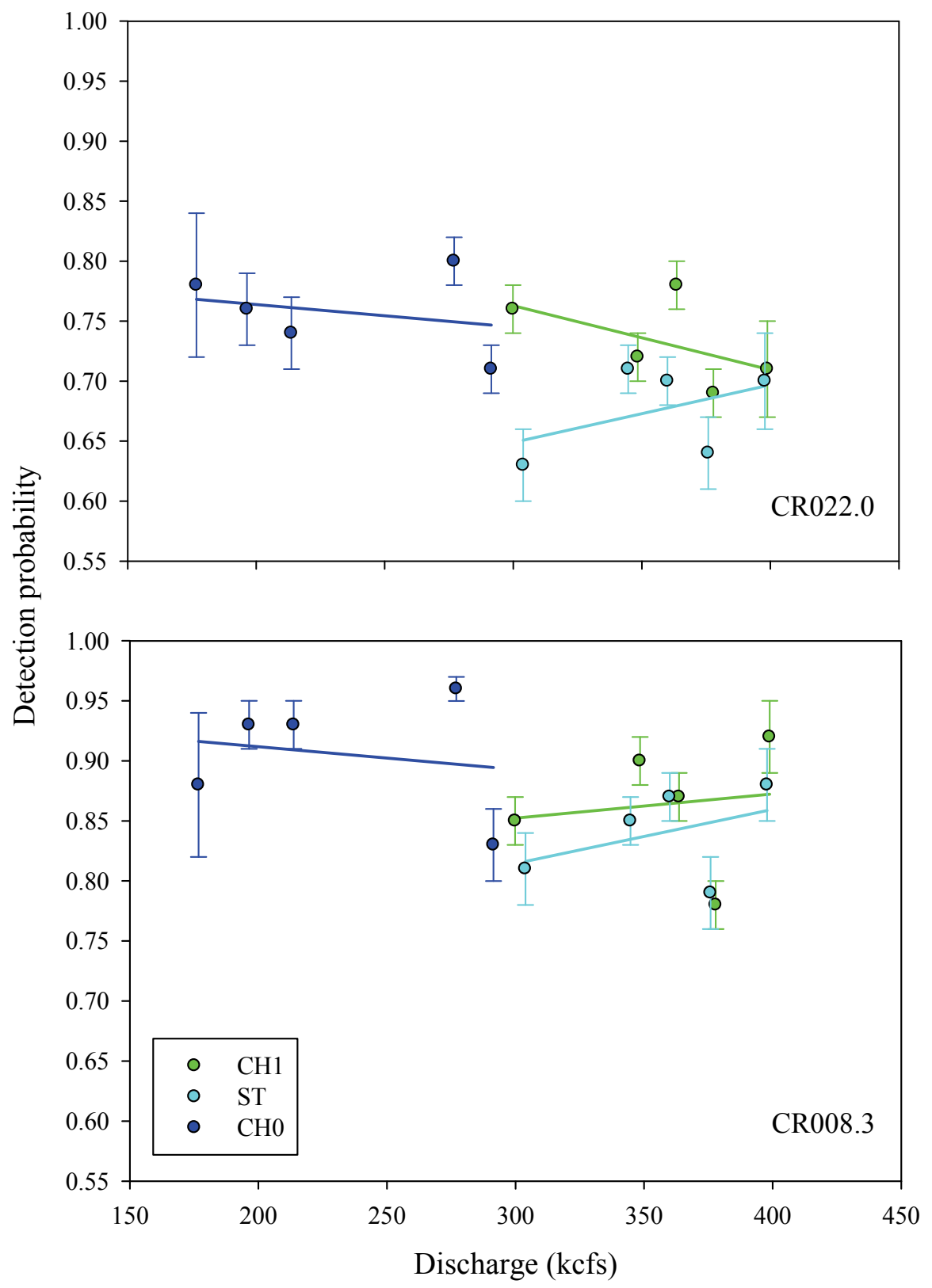

Figure 3.11. Detection probability of arrays at the Astoria Bridge (CR022.0) and East Sand Island (CR008.3) for each virtual release group of yearling Chinook salmon (CH1), steelhead (ST), and subyearling Chinook salmon (CH0) versus Columbia River discharge measured near Oak Point (rkm 86). Error bars denote one standard error.

\subsubsection{Burnham Tests of Survival Model Assumptions}

Results of Burnham tests indicated that there were no problems with upstream detections affecting downstream detections and/or survival at most arrays. Fewer than 10\% (12 of 150; $\%$ ) of the tests were significant at $\alpha=0.05$ for all virtual release groups, stocks, and arrays (except Harrington Point [CR037.3]) combined (Tables F.1 through F.21 in Appendix F). However, at CR037.3, 3 of 5 (60\%) 
calculated Test 2 statistics were significant for yearling Chinook salmon and steelhead, and 5 of 5 (100\%) were significant for subyearling Chinook salmon (Tables F.5, F. 11. and F.17 in Appendix F). These results suggest that fish were more likely to be detected at CR037.3 if they were previously detected at the Three Tree Point array (CR049.6). Because these were partial arrays, only spanning the width of the primary channel, fish migrating outside the primary channel at CR049.6 were less likely to be detected at CR037.3 than fish migrating in the primary channel at CR049.6. Because detection histories at CR037.3 failed Test 2, reach survival estimates were not calculated for the reach between CR049.6 and CR037.3. Instead, reach survivals were estimated between CR049.6 and the Astoria Bridge array (CR022.0). Detection of fish at CR022.0 was not influenced by detection histories at CR049.6 for most virtual release groups, as indicated by the low number ( 2 of $15 ; 13 \%$ ) of calculated Test 2 statistics found to be significant (Tables D.6, F. 12, and F.18).

\subsubsection{Survival Probability}

The probability of survival for yearling Chinook salmon from the Bonneville Dam forebay array (CR236.0) to the mouth of the Columbia River (CR008.3) varied temporally from $0.74(\mathrm{SE}=0.02)$ to $0.85(0.03)$ for the virtual release groups (Figure 3.12). Temporal variations lacked any identifiable pattern. However, yearling Chinook salmon detected at CR236.0 during the week of May 14 had noticeably lower survival to each array than all other virtual release groups. The survival probability estimate for all yearling Chinook salmon from CR236.0 to CR008.3 was 0.78 (0.01). Survival of yearling Chinook salmon declined sharply in the downstream-most $50 \mathrm{~km}$ of the Columbia River estuary.

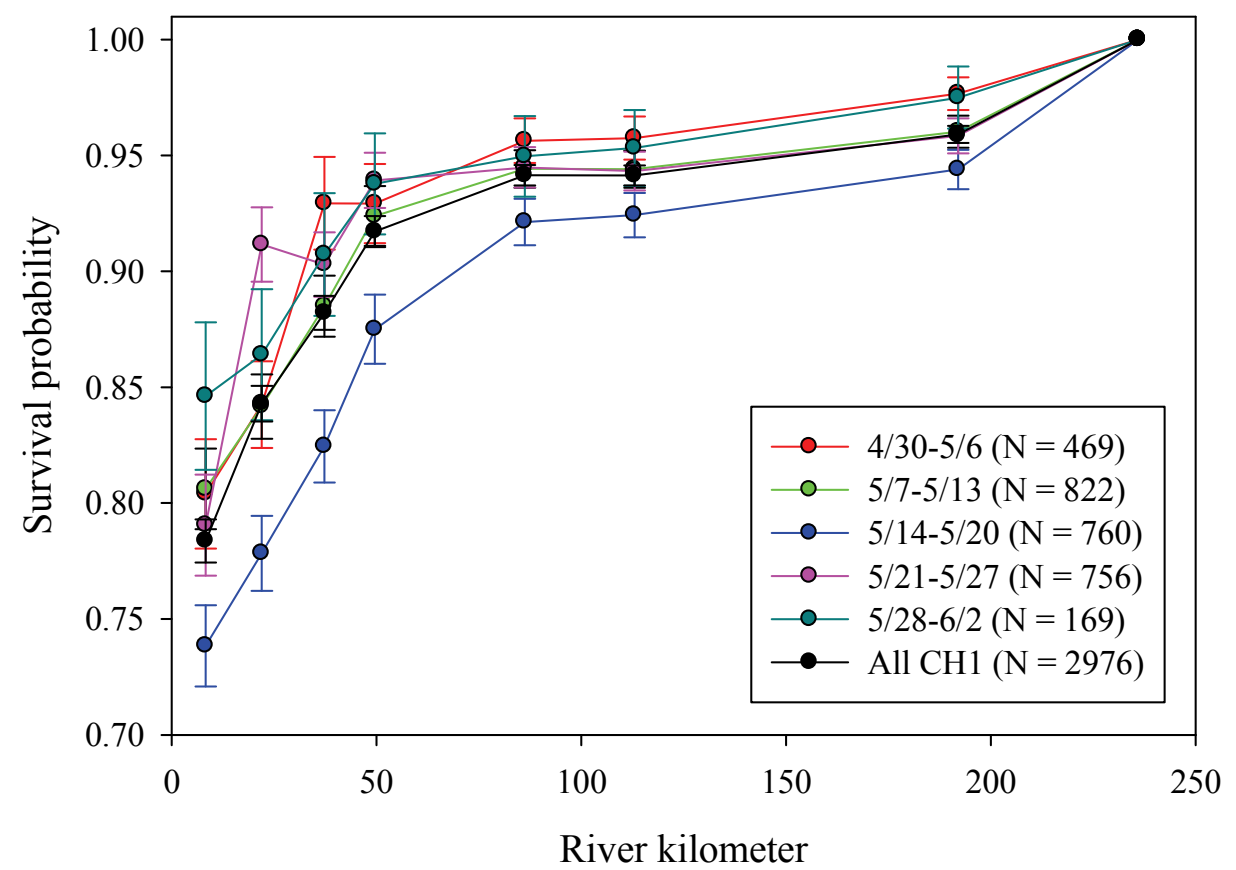

Figure 3.12. Survival probability of yearling Chinook salmon in 2009 from the Bonneville Dam forebay (rkm 236) by week of virtual release at the Bonneville Dam forebay array (CR236.0) and all fish pooled. Error bars denote one standard error. 
In 2009, overall reach survival estimates were highest for yearling Chinook salmon between the Cottonwood Island array (CR113.0) and the Oak Point array (CR086.2; $S=1.00 ; \mathrm{SE}=0.00)$ and lowest between the Three Tree Point array (CR049.6) and the Astoria Bridge array (CR022.0; $S=0.92$;

$\mathrm{SE}=0.01$; Figure 3.13). Although the reach survival estimate from the Bonneville Dam forebay array (CR236.0) to the Lady Island array (CR192.0) was relatively low $(S=0.96 ; \mathrm{SE}=0.00)$ compared to other reaches upstream of CR049.6, survival of yearling Chinook salmon through this reach was high per kilometer (0.9991; Figure 3.14). Survival per kilometer remained high $(>0.996)$ for each reach down to rkm 22. Between rkm 22 and rkm 8.3 survival per kilometer was much lower (0.9824).

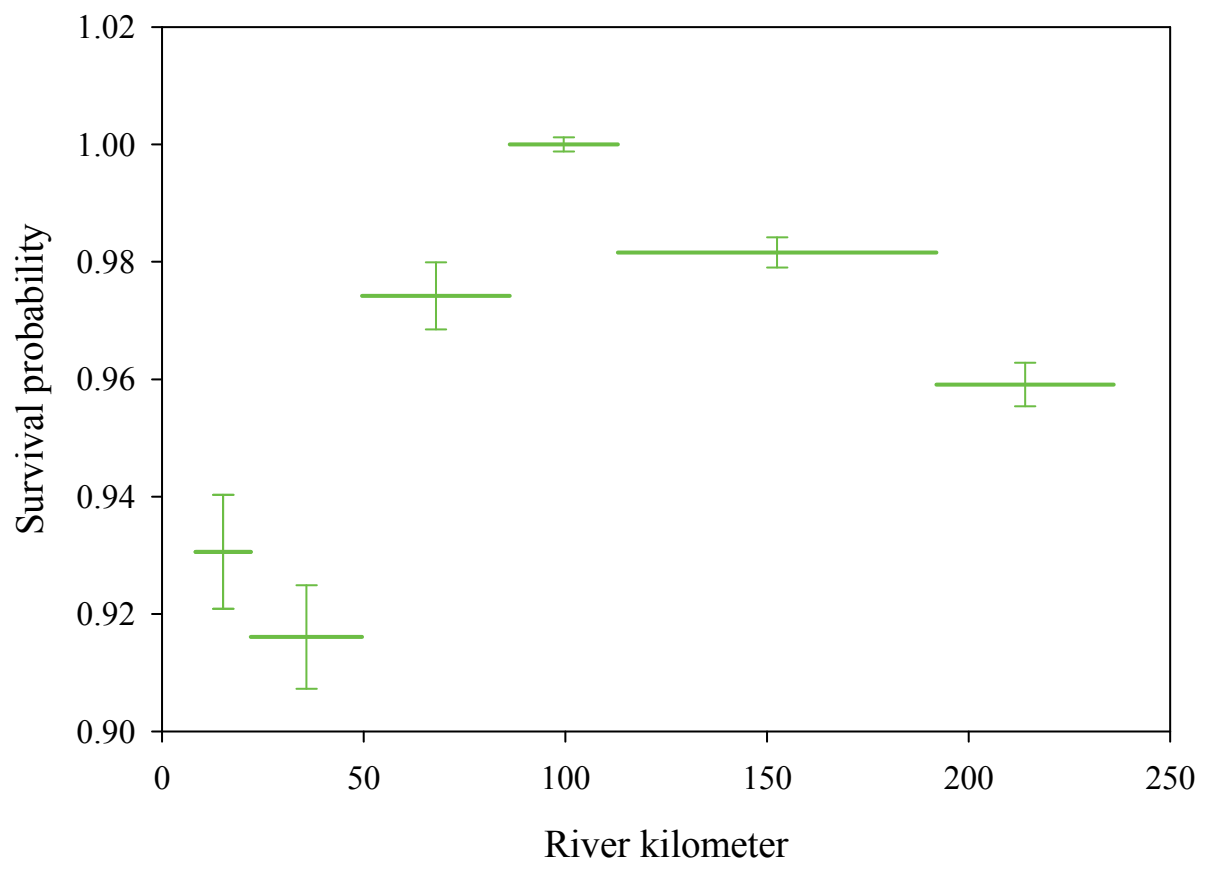

Figure 3.13. Reach survival probability estimates for all acoustic-tagged yearling Chinook salmon detected in 2009 at the Bonneville Dam forebay array (CR236.0). Error bars denote one standard error.

The probability of survival for steelhead smolts from the Bonneville Dam forebay (CR236.0) to the mouth of the Columbia River (CR008.3) in 2009 varied temporally from 0.47 ( $\mathrm{SE}=0.02)$ to $0.60(0.03)$ for the virtual release groups (Figure 3.15). Temporal variations lacked any identifiable pattern. The survival probability estimate for all steelhead smolts from CR236.0 to CR008.3 was 0.53 (0.01). Survival of steelhead smolts declined sharply in the downstream-most $86 \mathrm{~km}$ of the Columbia River estuary.

Similar to yearling Chinook salmon, overall reach survival estimates were highest for steelhead smolts between the Cottonwood Island array (CR113.0) and the Oak Point array (CR086.2; $\mathrm{S}=1.00$; $\mathrm{SE}=0.00)$ and lowest between the Three Tree Point array (CR049.6) and the Astoria Bridge array (CR022.0; $\mathrm{S}=0.77 ; \mathrm{SE}=0.02$; Figure 3.16). Estimates of survival per kilometer were high $(\geq 0.9997)$ in the upper estuary (upstream of rkm 86) but declined through each reach between rkm 86 and rkm 8 (Figure 3.17). The decline in survival appeared to occur farther upstream (around rkm 86) for steelhead than for yearling Chinook salmon. 


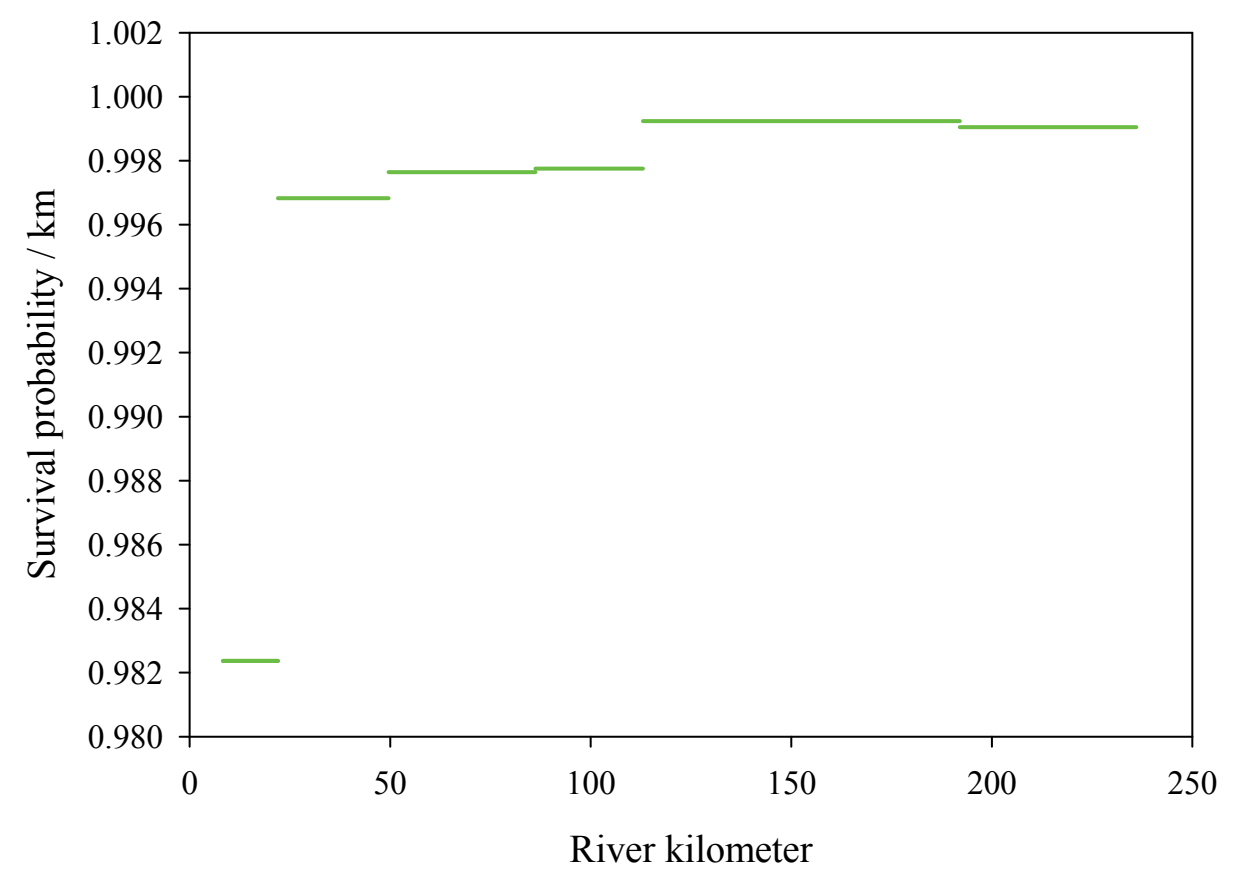

Figure 3.14. Survival probability per river kilometer for all acoustic-tagged yearling Chinook salmon detected in 2009 at the Bonneville Dam forebay array (CR236.0).

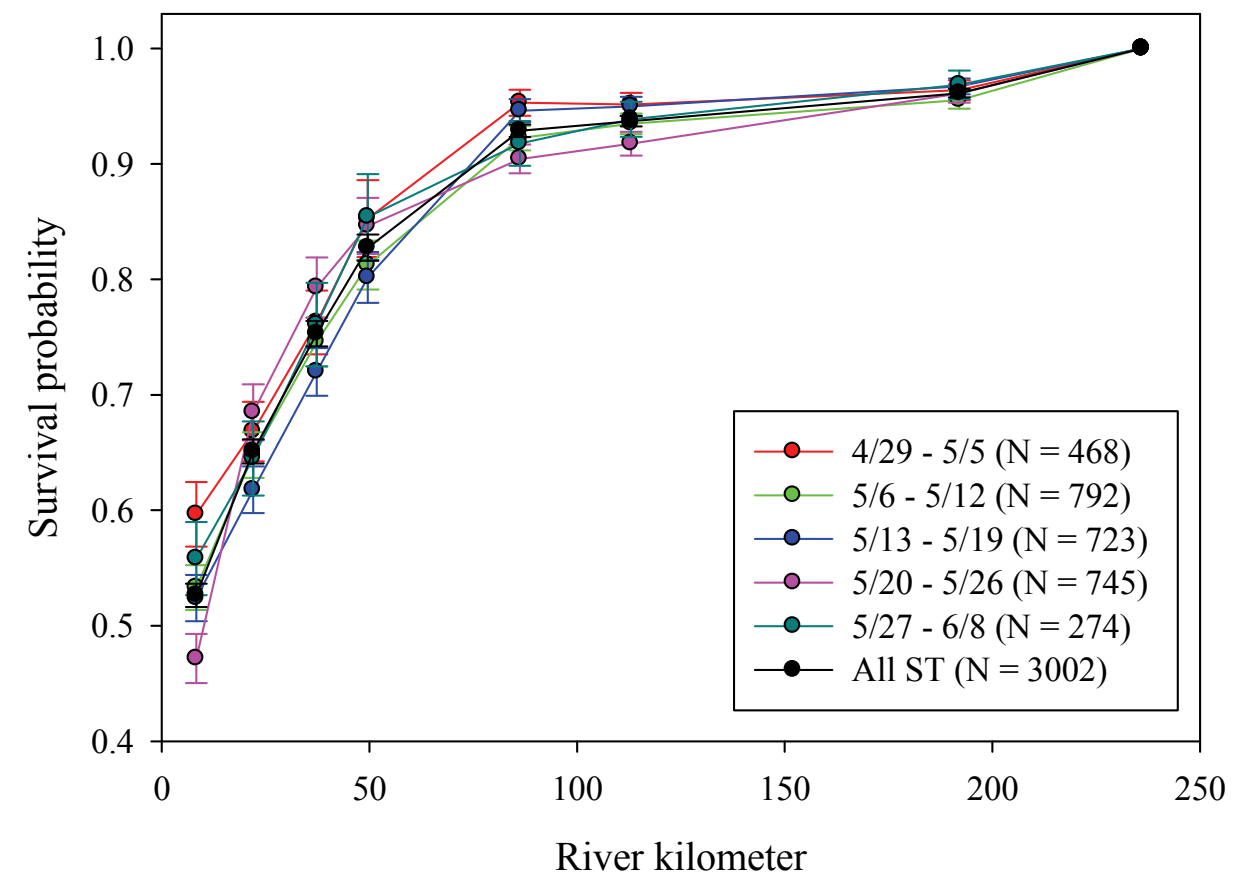

Figure 3.15. Survival probability of acoustic-tagged steelhead from the Bonneville Dam forebay (rkm 236) by week of virtual release and all fish pooled in 2009. Error bars denote one standard error. 


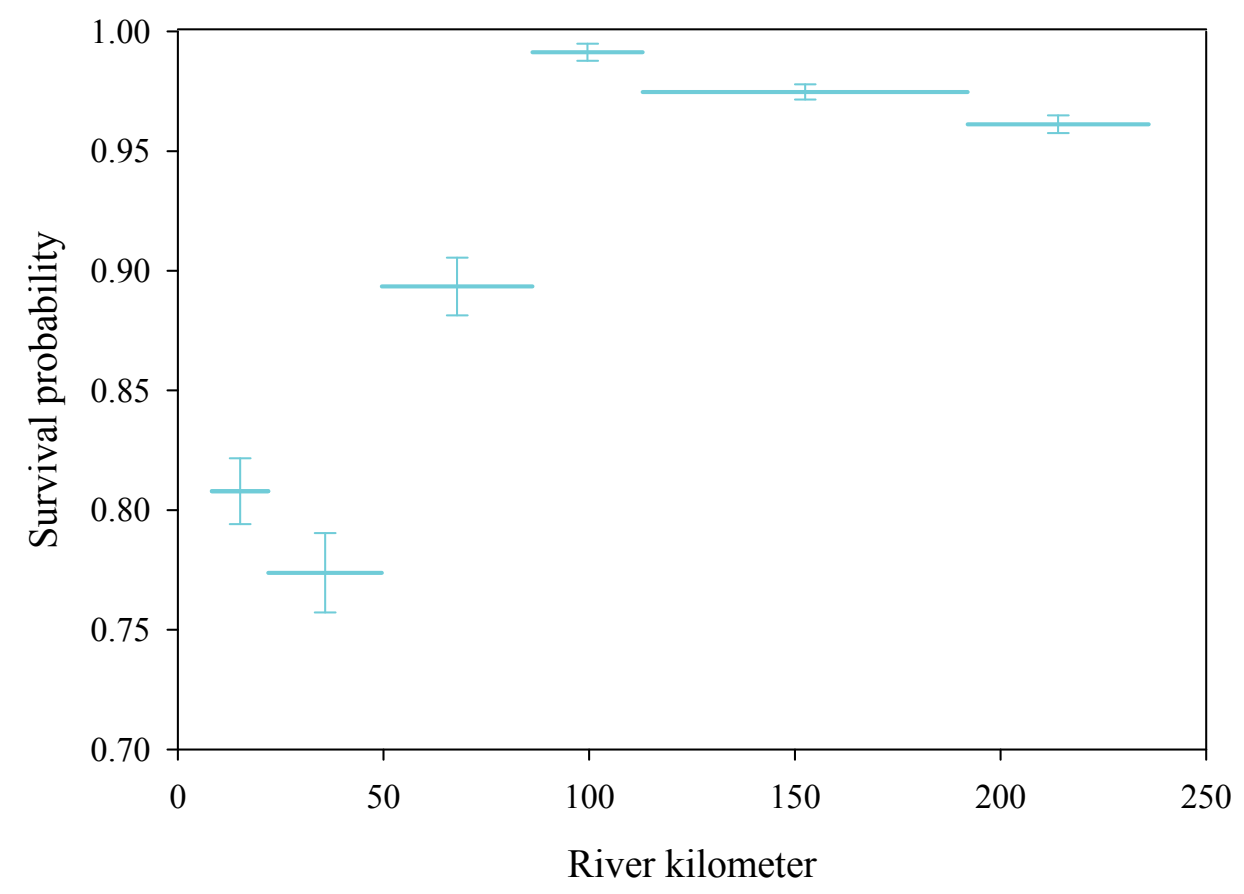

Figure 3.16. Reach survival probability estimates for all acoustic-tagged steelhead detected at the Bonneville Dam forebay array (CR236.0) in 2009. Error bars denote one standard error.

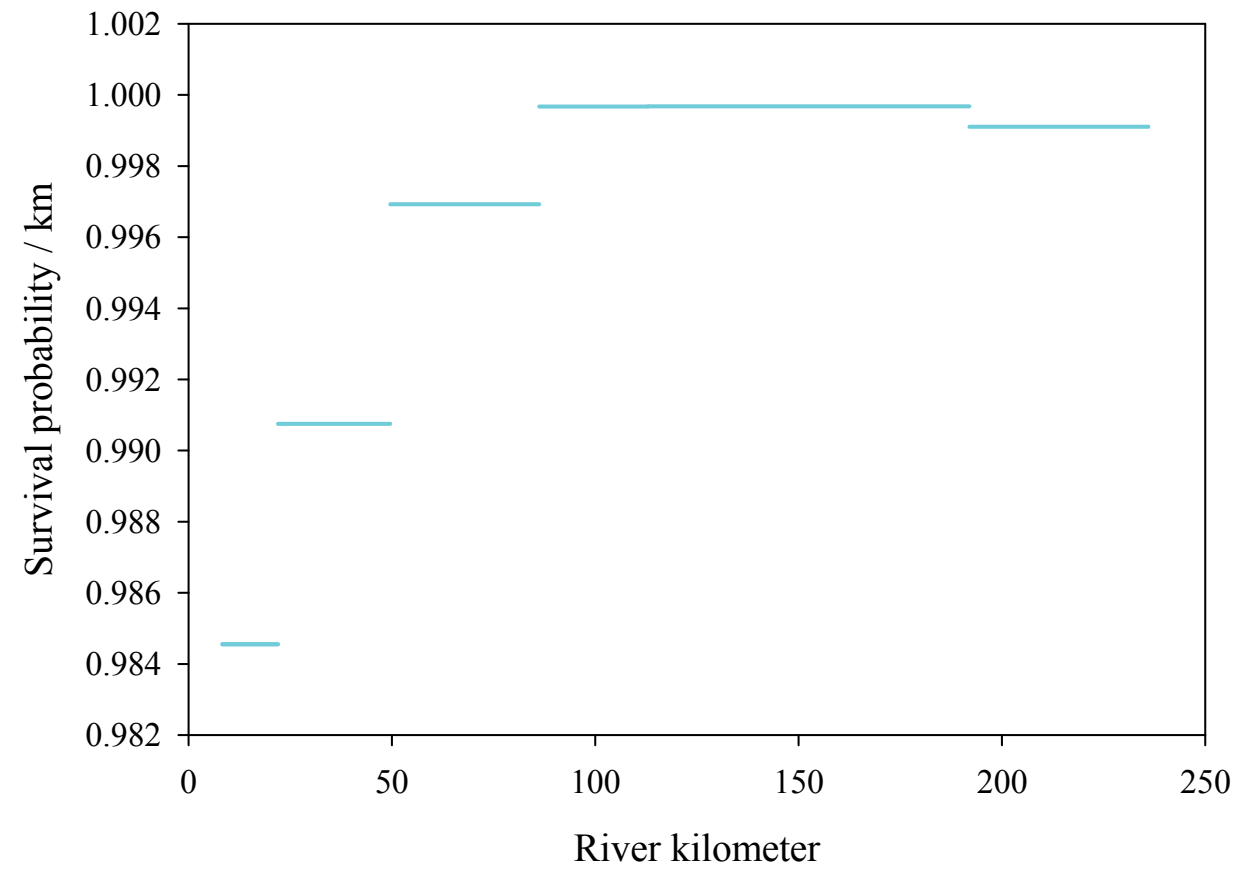

Figure 3.17. Survival probability per river kilometer for all acoustic-tagged steelhead detected at the Bonneville Dam forebay array (CR236.0) in 2009. 
Survival probability for subyearling Chinook salmon in 2009 from the Bonneville Dam forebay (CR236.0) to the mouth of the river (CR008.3) ranged from $0.78(0.03)$ to $0.36(0.04)$, declining for each successive virtual release group as the season progressed (Figure 3.18). Overall survival for all subyearling Chinook salmon between CR236.0 and CR008.3 was 0.64 (0.01). Mortality of subyearling Chinook salmon was more evenly distributed from CR236.0 to CR008.3 than observed for yearling Chinook salmon and steelhead, which had high survival rates in the upper estuary before declining sharply around rkm 50 .

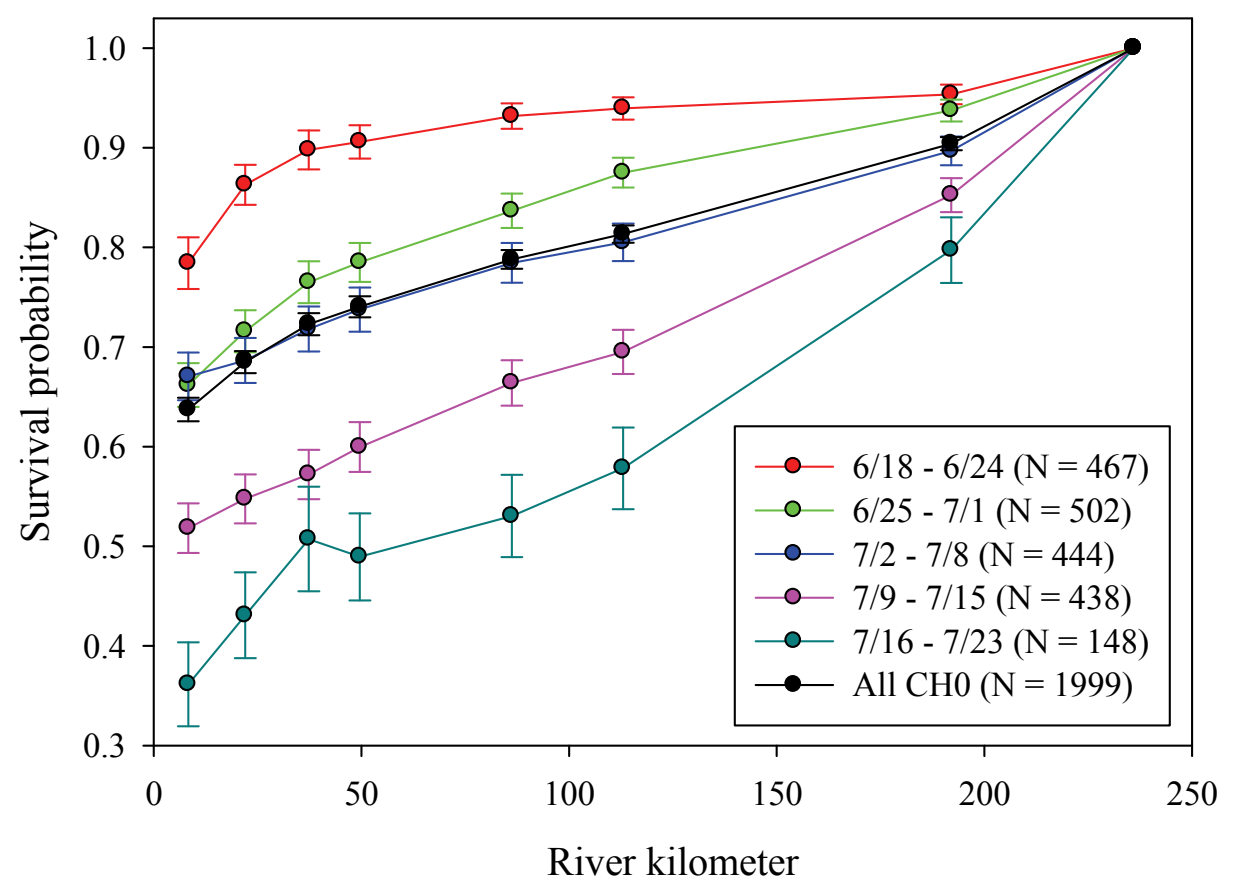

Figure 3.18. Survival probability of subyearling Chinook salmon from the Bonneville Dam forebay (rkm 236) by week of virtual release in 2009.

Similar to the reach survival estimates obtained for yearling Chinook salmon and steelhead in 2009, reach survival estimates for subyearling Chinook salmon were highest between the Cottonwood Island array (CR113.0) and the Oak Point array (CR086.0; $S=0.97 ; \mathrm{SE}=0.01$; Figure 3.19). However, reach survival estimates were lowest for subyearling Chinook salmon between the Lady Island array (CR192.0) and CR113.0 $(S=0.90 ; \mathrm{SE}=0.01)$. The trend in survival per kilometer estimates observed for subyearling Chinook salmon was similar to that observed for yearling Chinook salmon and steelhead, with higher survival $(>0.997)$ in the upper estuary (upstream of rkm 50) and lower survival $(<0.997)$ downstream of rkm 50, with the lowest survival between the Astoria Bridge array (CR022.0) and the East Sand Island array (CR008.3; Figure 3.20). However, survival per kilometer from the forebay of Bonneville Dam (CR236.0) to the Lady Island array (CR192.0) located in the Bonneville Dam tailrace was considerably lower for subyearling Chinook salmon than for yearling Chinook salmon and steelhead. 


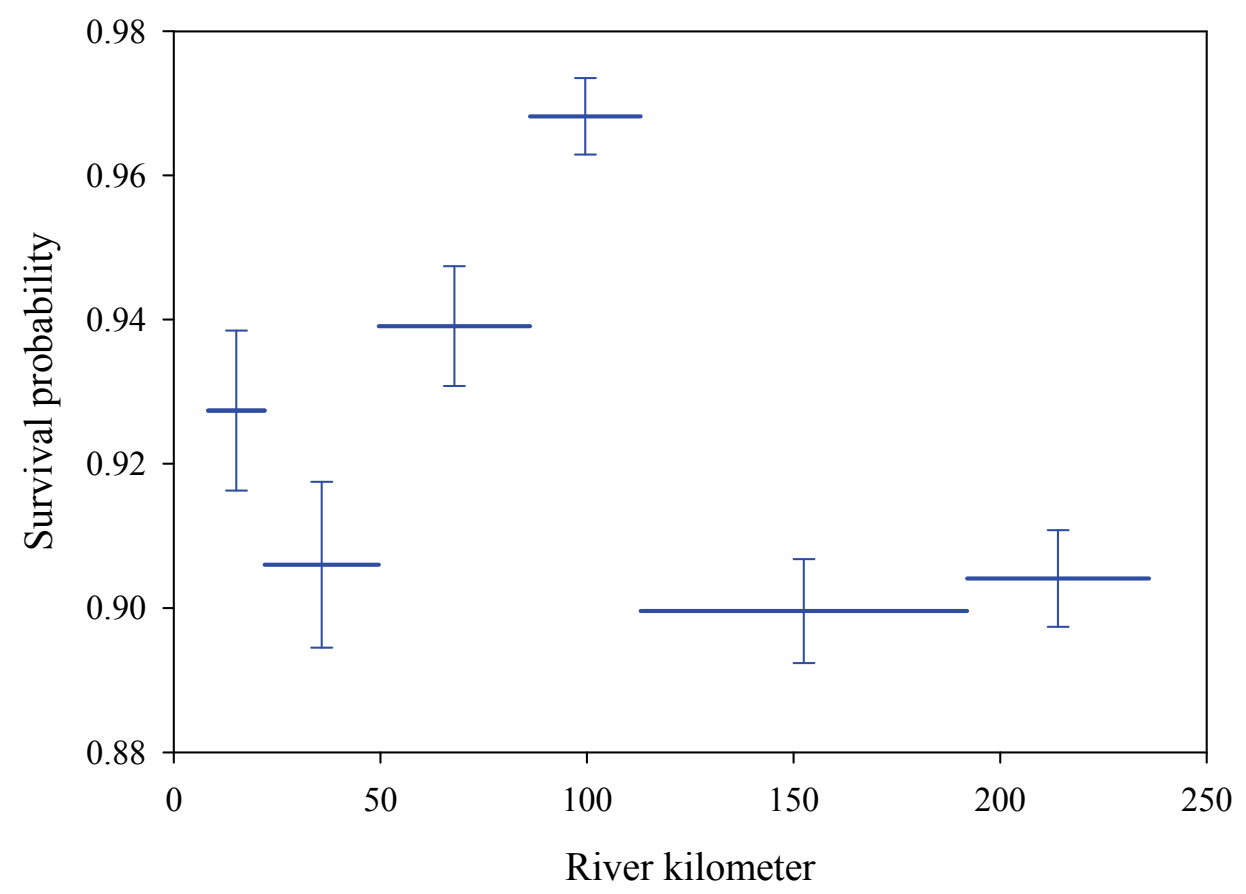

Figure 3.19. Reach survival probability estimates for all subyearling Chinook salmon detected at the Bonneville Dam forebay array (CR236.0) in 2009. Error bars denote one standard error.

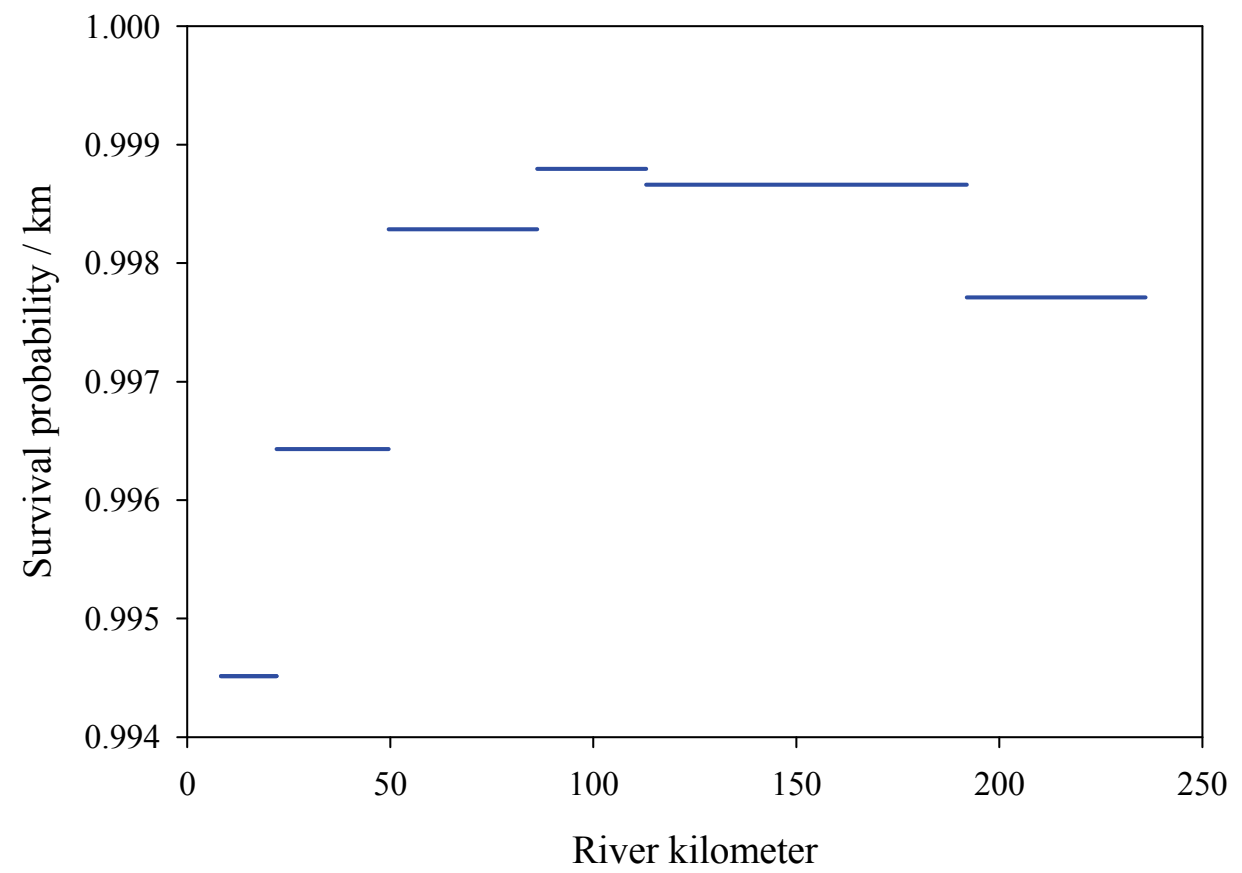

Figure 3.20. Survival probability per river kilometer for all subyearling Chinook salmon detected at the Bonneville Dam forebay array (CR236.0) in 2009. 


\subsubsection{Survival by Dam Passage Routes}

The passage route combination that resulted in the highest survival of yearling Chinook salmon from the Lady Island array (CR192.0) to the mouth of the Columbia River (CR008.3) was surface spill (through the TSW) passage at John Day Dam combined with passage through the juvenile bypass system at Bonneville Dam (Table 3.1). Passage through the JBS at John Day Dam combined with passage through the corner collector at Bonneville Dam also resulted in high survival from CR192.0 to CR008.3. The passage route combination that resulted in the lowest survival probability estimate for yearling Chinook salmon from CR192.0 to CR008.3 included passage through the JBS at both John Day and Bonneville dams. However, survival estimates did not differ significantly between any of the possible route combinations (Appendix E).

Table 3.1. Survival of yearling Chinook salmon from the Lady Island array (CR192.0) to the East Sand Island array (CR008.3) by routes of passage at John Day and Bonneville dams.

\begin{tabular}{|c|c|c|c|c|c|c|c|c|c|}
\hline & \multicolumn{8}{|c|}{ John Day Dam route } \\
\hline & & & JBS & & ep spill & & ГSW & & urbine \\
\hline \multirow{4}{*}{ 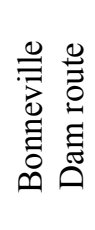 } & & $\mathrm{N}$ & $S(\mathrm{SE})$ & $\mathrm{N}$ & $S(\mathrm{SE})$ & $\mathrm{N}$ & $S(\mathrm{SE})$ & $\mathrm{N}$ & $S(\mathrm{SE})$ \\
\hline & $\mathrm{B} 2 \mathrm{CC}$ & 47 & $0.95(0.07)$ & 169 & $0.81(0.04)$ & 103 & $0.80(0.04)$ & 18 & NA \\
\hline & JBS & 27 & $0.77(0.09)$ & 83 & $0.80(0.05)$ & 49 & $0.95(0.06)$ & 9 & NA \\
\hline & Turbine & 40 & $0.79(0.07)$ & 165 & $0.91(0.04)$ & 85 & $0.80(0.06)$ & 38 & $0.84(0.07)$ \\
\hline
\end{tabular}

The passage route combination that resulted in the highest survival of steelhead from the Lady Island array (CR192.0) to the mouth of the Columbia River (CR008.3) was through the deep spill route at John Day Dam and through the corner collector at Bonneville Dam (Table 3.2). The passage route combination that resulted in the lowest survival probability estimate for steelhead from CR192.0 to CR008.3 included passage through the JBS at both John Day and Bonneville dams. Passage through the JBS at John Day Dam followed by passage through the corner collector at Bonneville Dam also resulted in low survival. Steelhead that passed through the deep spillway route at John Day Dam followed by passage through the corner collector at Bonneville Dam had a significantly higher probability of surviving from CR192.0 to CR008.3 than steelhead with the following detection histories: JBS at John Day Dam and corner collector at Bonneville Dam; TSW at John Day Dam and corner collector at Bonneville Dam; and JBS at both John Day and Bonneville dams (Table in Appendix). Additionally, steelhead that passed John Day Dam through the TSW followed by passage through turbines at Bonneville Dam had a significantly higher probability of survival from CR192.0 to CR008.3 than steelhead that passed through the JBS at John Day Dam followed by passage through the corner collector at Bonneville Dam (Appendix E).

The passage route combination that resulted in the highest survival of subyearling Chinook salmon from the Lady Island array (CR192.0) to the mouth of the Columbia River (CR008.3) was through the JBS at John Day Dam and through the corner collector at Bonneville Dam (Table 3.3). The passage route combination that resulted in the lowest survival probability estimate for subyearling Chinook salmon from CR192.0 to CR008.3 included deep spill passage at John Day Dam and JBS passage at Bonneville Dam. Passage through turbines at both John Day and Bonneville dams also resulted in low survival from CR192.0 to CR008.3. However, survival estimates did not differ significantly between any of the possible route combinations (Appendix E). 
Table 3.2. Survival of steelhead from the Lady Island array (CR192.0) to the East Sand Island array (CR008.3) by routes of passage at John Day and Bonneville dams, 2009.

\begin{tabular}{|c|c|c|c|c|c|c|c|c|c|}
\hline & \multicolumn{8}{|c|}{ John Day Dam route } \\
\hline & & \multicolumn{2}{|r|}{ JBS } & \multicolumn{2}{|c|}{ Deep spill } & \multicolumn{2}{|c|}{ TSW } & \multicolumn{2}{|c|}{ Turbine } \\
\hline \multirow{4}{*}{ 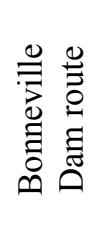 } & \multirow[b]{2}{*}{$\mathrm{B} 2 \mathrm{CC}$} & $\mathrm{N}$ & $S(\mathrm{SE})$ & $\mathrm{N}$ & $S(\mathrm{SE})$ & $\mathrm{N}$ & $S(\mathrm{SE})$ & $\mathrm{N}$ & $S(\mathrm{SE})$ \\
\hline & & 102 & $0.45(0.05)$ & 137 & $0.70(0.05)$ & 273 & $0.56(0.03)$ & 18 & NA \\
\hline & JBS & 26 & $0.42(0.10)$ & 39 & $0.64(0.09)$ & 56 & $0.58(0.07)$ & 3 & NA \\
\hline & Turbine & 53 & $0.59(0.07)$ & 52 & $0.55(0.08)$ & 115 & $0.65(0.05)$ & 14 & NA \\
\hline
\end{tabular}

Table 3.3. Survival of subyearling Chinook salmon from the Lady Island array (CR192.0) to the East Sand Island array (CR008.3) by routes of passage at John Day and Bonneville dams. The TSW was not operated at John Day Dam during summer 2009.

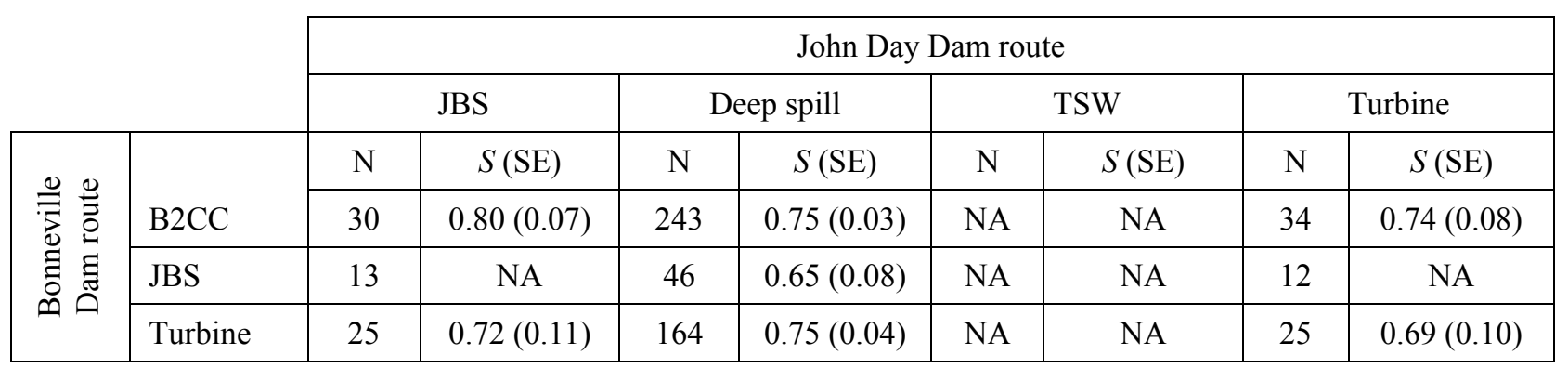

\subsection{Migration Behavior}

\subsubsection{Travel Time}

Acoustic-tagged yearling Chinook salmon that were detected in the Bonneville Dam forebay (CR236.0) and at the East Sand Island array (CR008.3) had a mean travel time of $3.4(\mathrm{SE}=0.03) \mathrm{d}$ and a median travel time of $3.1 \mathrm{~d}$. Travel times decreased throughout the migration period from a median of $4.1 \mathrm{~d}$ for the earliest migrants to a median of $2.6 \mathrm{~d}$ for the later migrants (Figure 3.21). Travel rates through the Columbia River and estuary also varied by reach with an increase in speed from the Bonneville Dam forebay to Oak Point (CR086.2), a subsequent decrease in speed to the Astoria Bridge array (CR022.0), and an increase in speed from the Astoria Bridge to East Sand Island (CR008.3; Figure 3.22).

Acoustic-tagged steelhead that were detected in the Bonneville Dam forebay (CR236.0) and at the East Sand Island array (CR008.3) had a mean travel time of $3.1(\mathrm{SE}=0.04) \mathrm{d}$ and a median travel time of $2.9 \mathrm{~d}$. Similar to yearling Chinook salmon, travel times decreased throughout the migration period, from a median of $3.4 \mathrm{~d}$ for the earliest migrants to a median of $2.5 \mathrm{~d}$ for the later migrants (Figure3.23). Travel rates through the Columbia River and estuary were also comparable to yearling Chinook salmon by reach with an increase in speed from the Bonneville Dam forebay to Oak Point (CR086.2), a subsequent decrease in speed to the Astoria Bridge array (CR022.0), and an increase in speed from the Astoria Bridge to East Sand Island (CR008.3; Figure 3.24). 


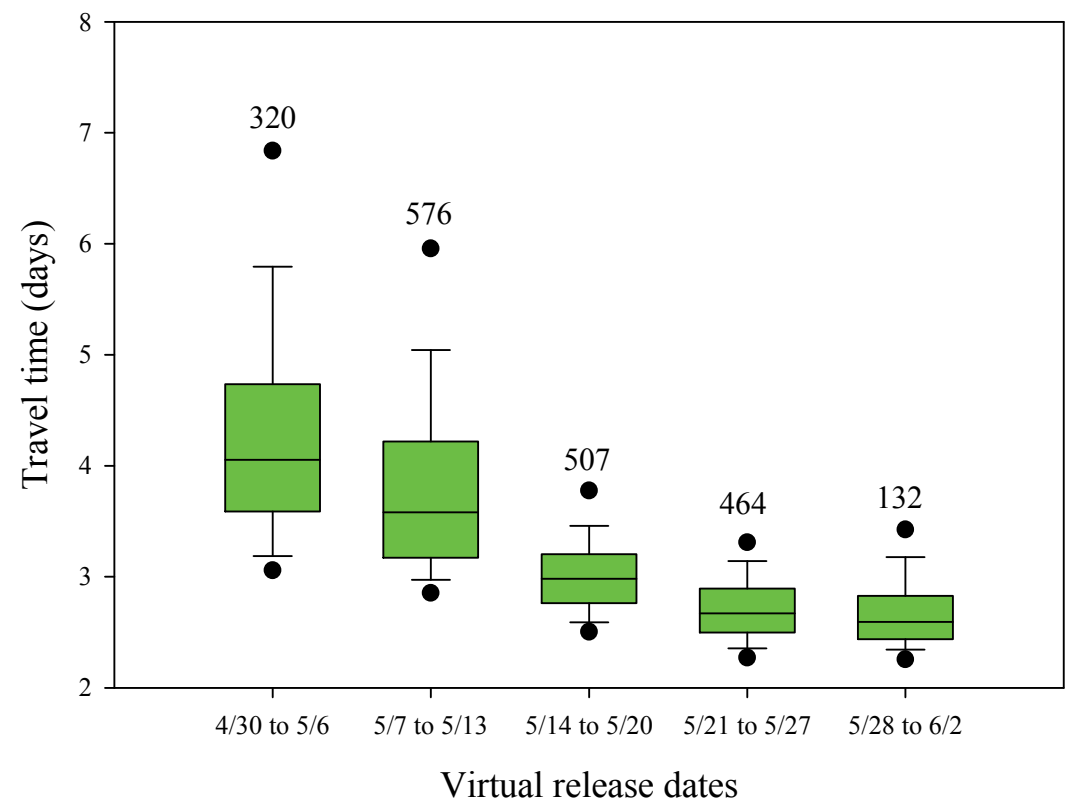

Figure 3.21. Travel time (days) of juvenile yearling Chinook salmon from the Bonneville Dam forebay (rkm 236) to detection at the Columbia River mouth (rkm 8.3). Solid lines within the boxes are medians, the box boundary represents the 25 th and 75 th percentiles, whiskers indicate the 10th and 90th percentiles, and dots indicate the 5th and 95th percentiles. Numbers above each bar are sample sizes.

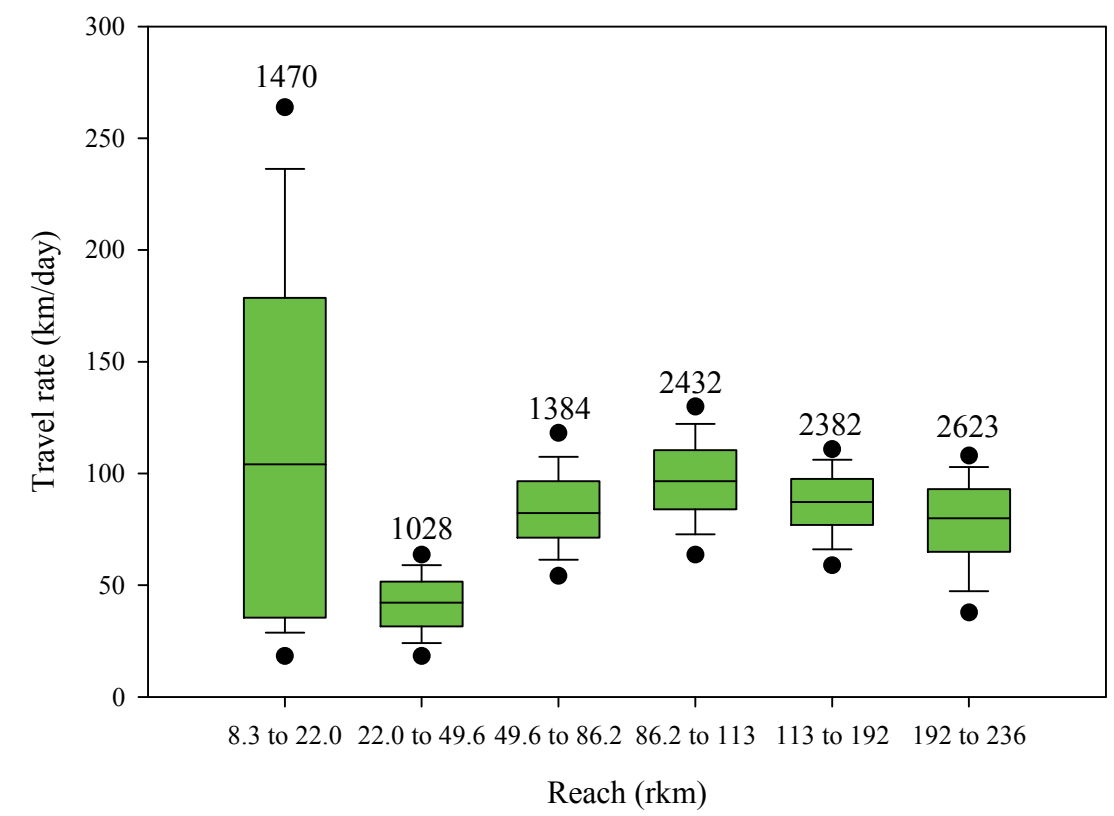

Figure 3.22. Travel rate ( $\mathrm{km} /$ day) of juvenile yearling Chinook salmon in reaches of the Columbia River from the Bonneville Dam forebay (rkm 236) to the river mouth (rkm 8.3). Solid lines within the boxes are medians, the box boundary represents the 25 th and 75 th percentiles, whiskers indicate the 10th and 90th percentiles, and dots indicate the 5th and 95th percentiles. Numbers above each bar are sample sizes. 


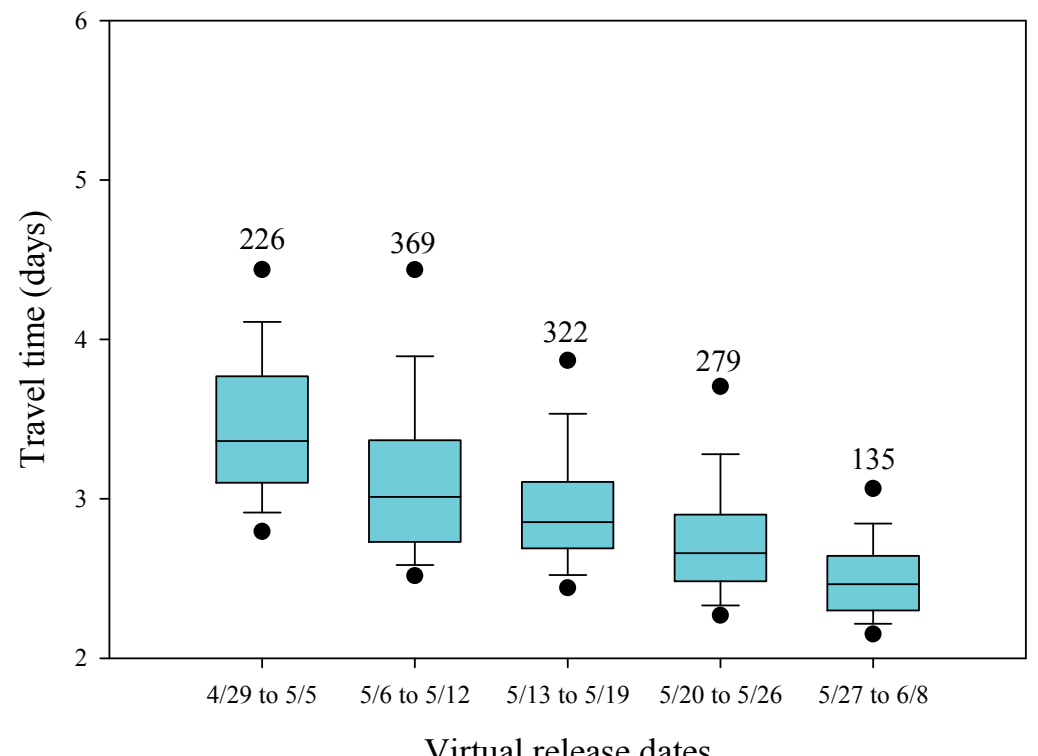

Figure 3.23. Travel time (days) of juvenile steelhead from the Bonneville Dam forebay (rkm 236) to detection at the Columbia River mouth (rkm 8.3). Solid lines within the boxes are medians, the box boundary represents the 25 th and 75 th percentiles, whiskers indicate the 10th and 90th percentiles, and dots indicate the 5th and 95th percentiles. Numbers above each bar are sample sizes.

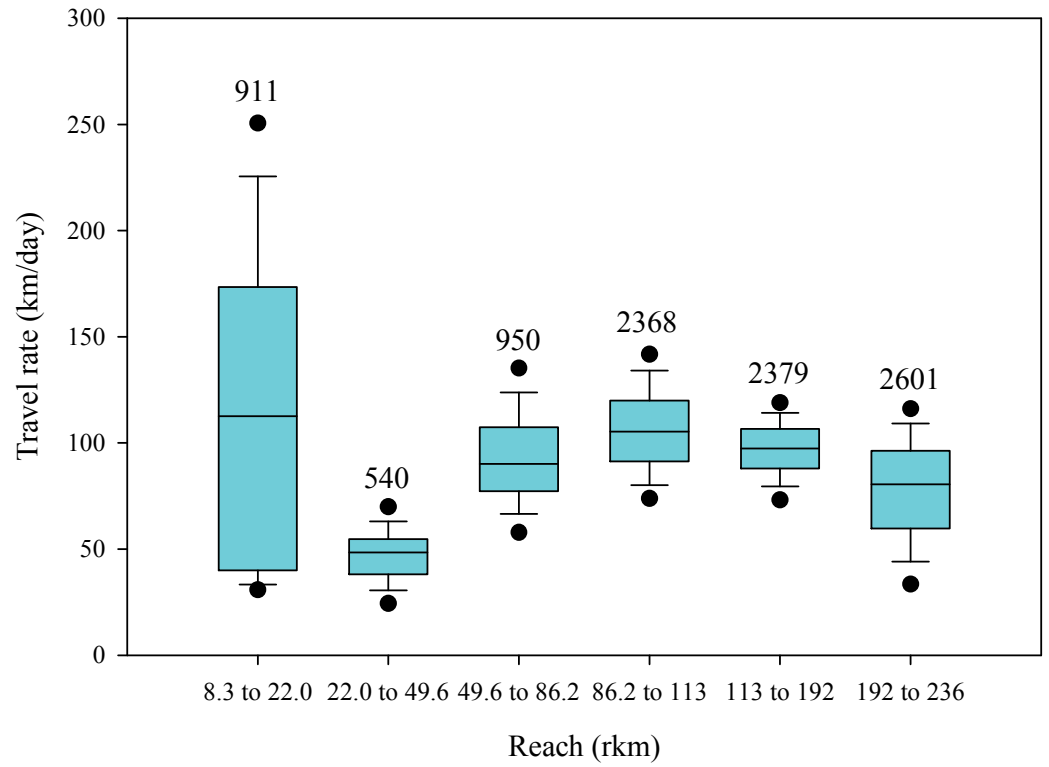

Figure 3.24. Travel rate ( $\mathrm{km} /$ day) of juvenile steelhead in reaches of the Columbia River from the Bonneville Dam forebay ( $\mathrm{rkm} 236$ ) to the river mouth (rkm 8.3). Solid lines within the boxes are medians, the box boundary represents the 25 th and 75 th percentiles, whiskers indicate the 10th and 90th percentiles, and dots indicate the 5th and 95th percentiles. Numbers above each bar are sample sizes. 
Acoustic-tagged subyearling Chinook salmon that were detected in the Bonneville Dam forebay (CR236.0) and at the East Sand Island array (CR008.3) had a mean travel time of $4.1(\mathrm{SE}=0.04) \mathrm{d}$ and a median travel time of $3.9 \mathrm{~d}$. Travel times increased slightly throughout the migration period from a median of $3.5 \mathrm{~d}$ for the earliest migrants to a median of $4.4 \mathrm{~d}$ for the later migrants (Figure 3.25). Travel rates through the Columbia River and estuary also varied by reach with a general decrease in speed from the Bonneville Dam forebay to the Astoria Bridge array (CR022.0; Figure 3.26). Median travel rate from Three Tree Point (CR049.6) to the Astoria Bridge was $29.1 \mathrm{~km} / \mathrm{d}$; however, travel rate increased to a median of $41.7 \mathrm{~km} / \mathrm{d}$ through the final reach from the Astoria Bridge to East Sand Island. Travel rate through the final reach varied from 1.8 to $380.9 \mathrm{~km} / \mathrm{d}$ indicating significant variation among the population (Figure 3.26).

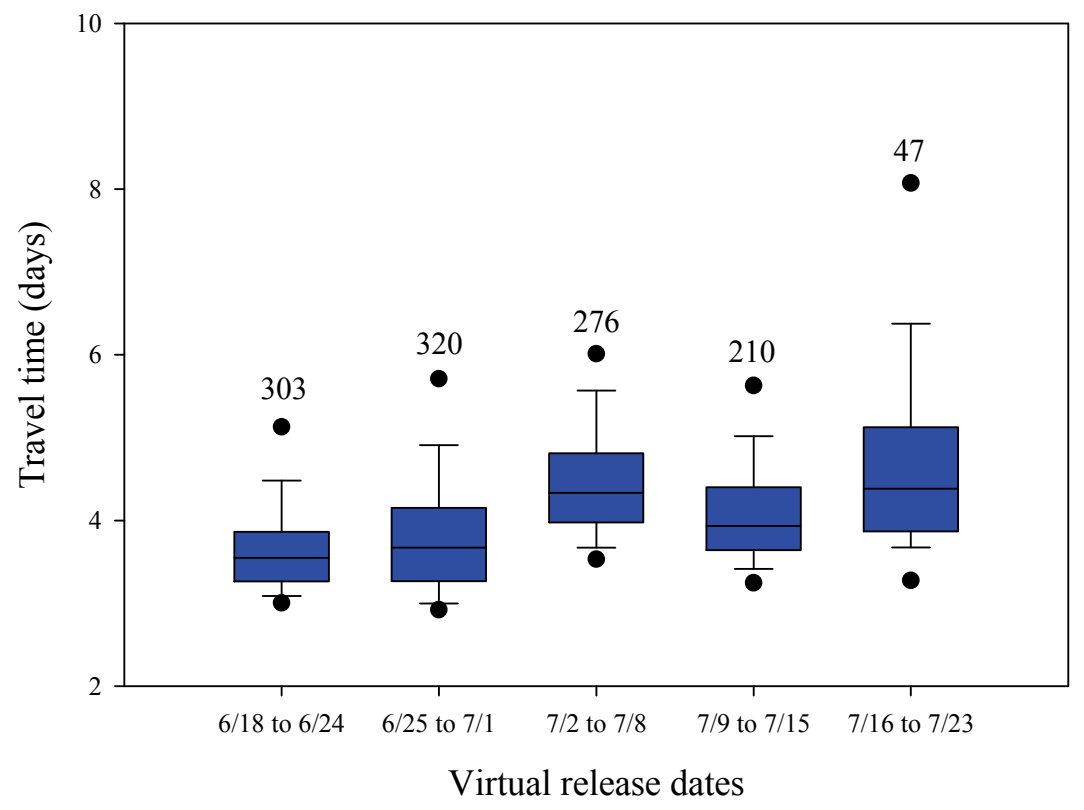

Figure 3.25. Travel time (days) of juvenile subyearling Chinook salmon from the Bonneville Dam forebay ( $\mathrm{rkm} 236$ ) to detection at the Columbia River mouth (rkm 8.3). Solid lines within the boxes are medians, the box boundary represents the 25 th and 75 th percentiles, whiskers indicate the 10th and 90th percentiles, and dots indicate the 5th and 95th percentiles. Numbers above each bar are sample sizes.

\subsubsection{Migration Pathways}

The majority of acoustic-tagged yearling Chinook salmon (65\%), subyearling Chinook salmon (57\%), and steelhead (74\%) were last detected at the Harrington Point array (CR037.3) by the receivers located on either side of the navigation channel (CR037.3_03 and CR037.3_04; Table3.4). Relatively few of these fish $(<10 \%)$ were detected in Grays Bay, which may indicate that most fish last detected near the navigation channel at Harrington Point continue to follow the navigation channel along the southern edge of Rice Island, rather than traverse through the shallow water area north of Rice Island and into Grays Bay. Fish last detected at the Harrington Point array by the receivers located closer to the Washington shore (CR037.3_01 and CR037.3_02) were more likely to be detected in Grays Bay (Table 3.4). A higher percentage of subyearling Chinook salmon detected at Harrington Point were later detected in Grays Bay (26\%) compared to yearling Chinook salmon (9\%) and steelhead (6\%). 


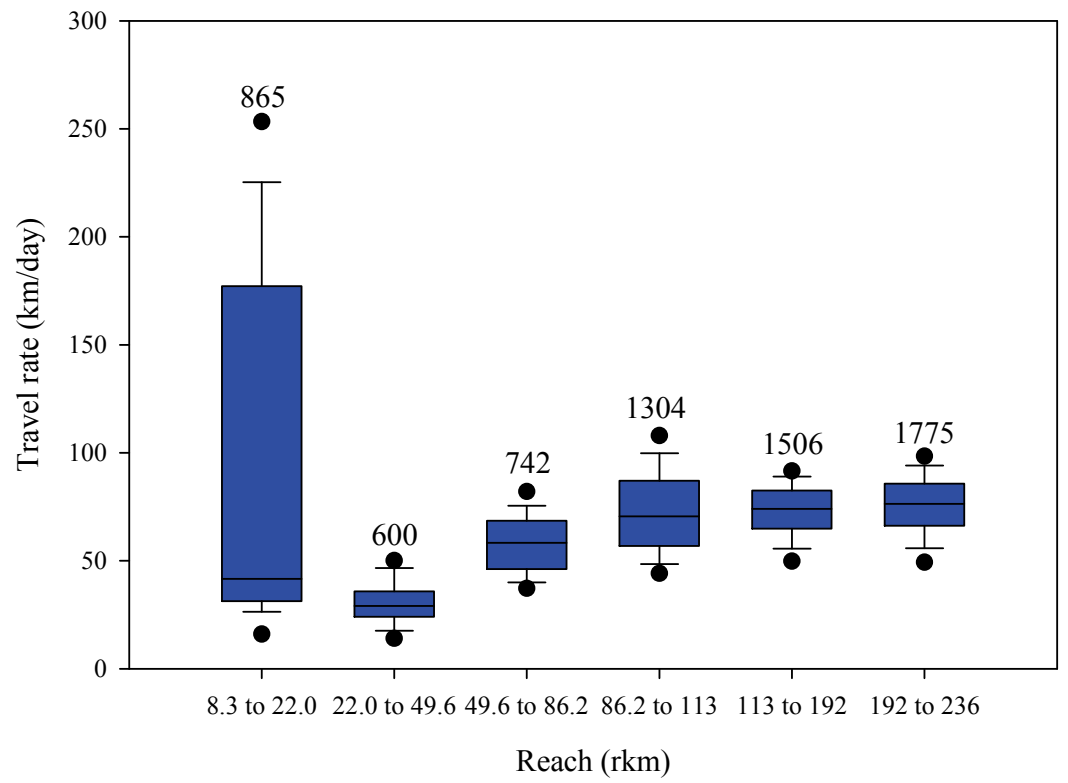

Figure 3.26. Travel rate $(\mathrm{km} / \mathrm{day})$ of juvenile subyearling Chinook salmon in reaches of the Columbia River from the Bonneville Dam forebay (rkm 236) to the river mouth (rkm 8.3). Solid lines within the boxes are medians, the box boundary represents the 25 th and 75 th percentiles, whiskers indicate the 10th and 90th percentiles, and dots indicate the 5th and 95th percentiles. Numbers above each bar are sample sizes.

Table 3.4. Number of acoustic-tagged yearling and subyearling Chinook salmon and steelhead last detected at each receiver of the Harrington Point array (CR037.3), and of those, the number and percentage detected in Grays Bay, and the number and percentage first detected in each channel at the Astoria Bridge array (CR022.0).

\begin{tabular}{|c|c|c|c|c|c|}
\hline \multirow{2}{*}{$\begin{array}{l}\text { Species / run type CR037.3 } \\
\text { receiver of last detection }\end{array}$} & \multirow{2}{*}{$\begin{array}{c}\mathrm{N} \text { last detected } \\
\text { at CR037.3 }\end{array}$} & \multirow{2}{*}{$\begin{array}{l}\mathrm{N}(\%) \text { detected in } \\
\text { Grays Bay }\end{array}$} & \multicolumn{3}{|c|}{ N (\%) first detected at CR022.0 (by channel) } \\
\hline & & & Washington & Mid & Oregon \\
\hline \multicolumn{6}{|l|}{ Yearling Chinook } \\
\hline CR037.3_01 & 102 & $65(64 \%)$ & $81(79 \%)$ & 0 & 0 \\
\hline CR037.3_02 & 406 & $46(11 \%)$ & $240(59 \%)$ & $10(3 \%)$ & $37(9 \%)$ \\
\hline CR037.3_03 & 715 & $13(2 \%)$ & $372(52 \%)$ & $27(4 \%)$ & $102(14 \%)$ \\
\hline CR037.3_04 & 238 & $5(2 \%)$ & $133(56 \%)$ & $9(4 \%)$ & $40(17 \%)$ \\
\hline Total & 1461 & $129(9 \%)$ & $826(57 \%)$ & $46(3 \%)$ & $179(12 \%)$ \\
\hline \multicolumn{6}{|l|}{ Steelhead } \\
\hline CR037.3_01 & 61 & $28(46 \%)$ & $30(49 \%)$ & $2(3 \%)$ & $3(5 \%)$ \\
\hline CR037.3_02 & 236 & $29(12 \%)$ & $107(45 \%)$ & $10(4 \%)$ & $29(12 \%)$ \\
\hline CR037.3_03 & 563 & $7(1 \%)$ & $236(42 \%)$ & $25(4 \%)$ & $71(13 \%)$ \\
\hline CR037.3_04 & 281 & $2(1 \%)$ & $132(47 \%)$ & $8(3 \%)$ & $37(13 \%)$ \\
\hline Total & 1141 & $66(6 \%)$ & $505(44 \%)$ & $45(4 \%)$ & $140(12 \%)$ \\
\hline \multicolumn{6}{|l|}{ Subyearling Chinook } \\
\hline CR037.3_01 & 130 & $92(71 \%)$ & $89(69 \%)$ & $1(1 \%)$ & $3(2 \%)$ \\
\hline CR037.3_02 & 194 & $68(35 \%)$ & $135(70 \%)$ & $2(1 \%)$ & $7(4 \%)$ \\
\hline CR037.3_03 & 324 & $28(9 \%)$ & $212(65 \%)$ & $12(4 \%)$ & $20(6 \%)$ \\
\hline CR037.3_04 & 98 & $5(5 \%)$ & $50(51 \%)$ & $5(5 \%)$ & $10(10 \%)$ \\
\hline Total & 746 & $193(26 \%)$ & $486(65 \%)$ & $20(3 \%)$ & $40(5 \%)$ \\
\hline
\end{tabular}


Regardless of whether fish migrated from Harrington Point (CR037.3) in the main navigation channel (south of Rice Island) or outside the main channel (through Grays Bay) the majority of acoustic-tagged yearling and subyearling Chinook salmon and steelhead that were detected at the Astoria Bridge (CR022.0) were first detected in the Washington channel (Table 3.4). Subyearling Chinook salmon, in particular, displayed a strong tendency to migrate near the Washington shoreline at the Astoria Bridge array.

The probability of survival was high for yearling Chinook salmon between Harrington Point (CR037.3) and the Astoria Bridge (CR022.0) regardless of which Harrington Point receiver they were last detected (Figure 3.27). These results indicate that the migration pathway used by yearling Chinook salmon to migrate from Harrington Point to the Astoria Bridge had little effect on their probability of surviving to the bridge.

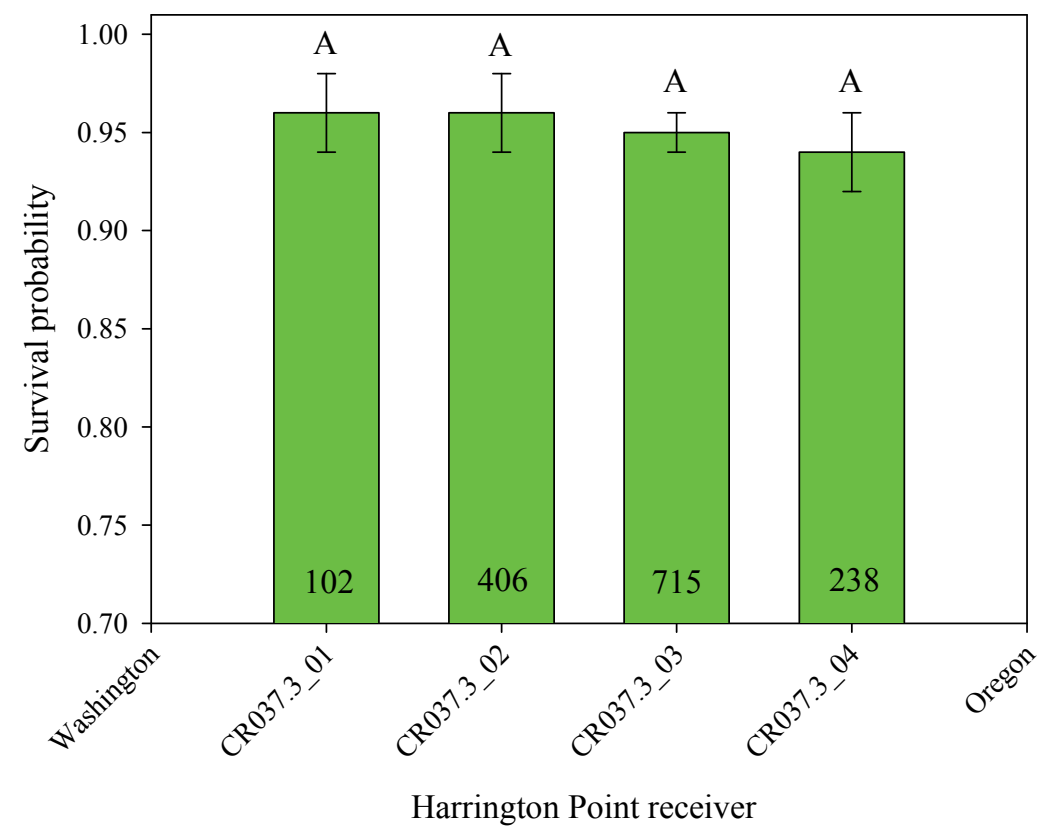

Figure 3.27. Survival probability of acoustic-tagged yearling Chinook salmon from the Harrington Point array (CR037.3) to the Astoria Bridge array (CR022.0) grouped by receiver of last detection at the Harrington Point array. Receiver CR037.3_01 was located closest to the Washington shore and receivers CR037.3_03 and CR037.3_04 were located on either side of the navigation channel. Sample sizes for each group are shown in each bar. Error bars denote one standard error. Dissimilar letters above each bar indicate a significant difference $(\alpha=0.05)$ from likelihood ratio tests.

The migration pathway used by steelhead to migrate from Harrington Point (CR037.3) to the Astoria Bridge (CR022.0) appeared to affect survival. Steelhead that migrated from the Harrington Point receiver located nearest to the Washington shoreline (CR037.3_01), the majority of which migrated through Grays Bay, had a survival probability of $0.74(\mathrm{SE}=0.06)$, which was lower than the survival of steelhead that migrated from Harrington Point in or near the navigation channel (CR037.3_03 and CR037.3_04; Figure 3.28). Similar to the observed survival of subyearling Chinook salmon, survival of steelhead from Grays Bay to the Astoria Bridge was relatively high (0.90; $\mathrm{SE}=0.05)$, indicating that much of the mortality of steelhead that migrated near the Washington shoreline at Harrington Point occurred in the shallow water area north of Rice Island (between Harrington Point and Grays Bay receivers). 


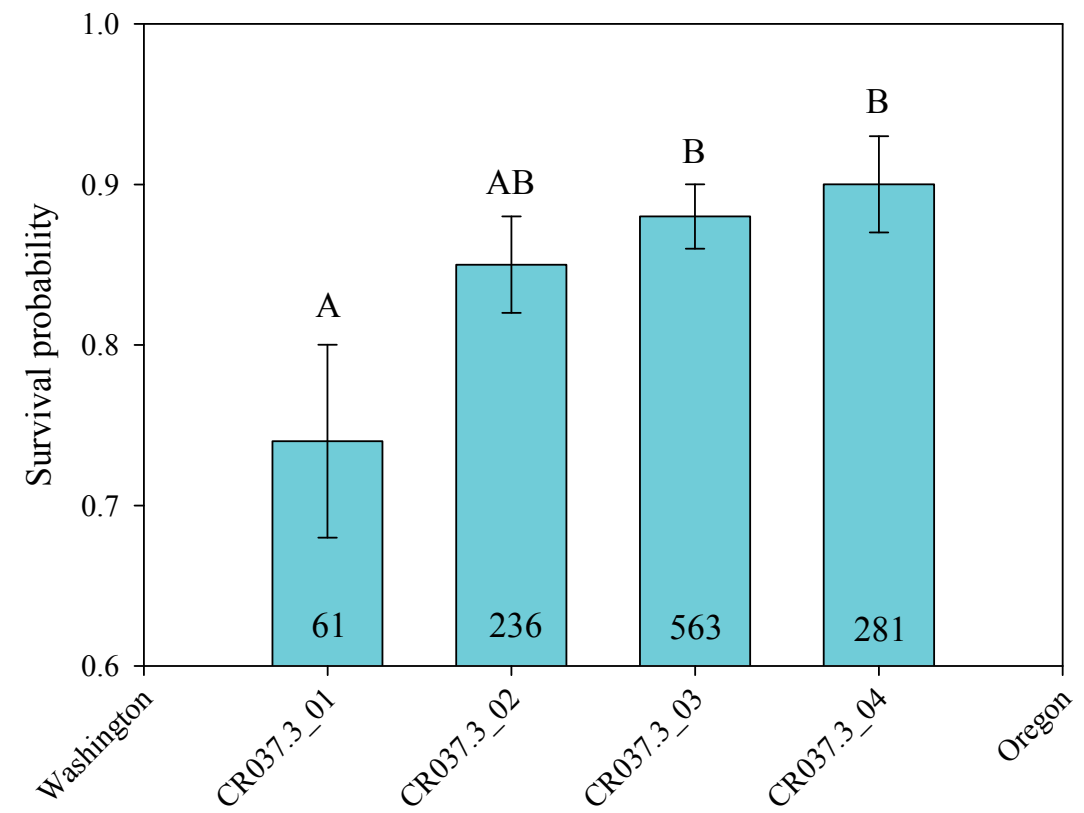

Harrington Point receiver

Figure 3.28. Survival probability of acoustic-tagged steelhead from the Harrington Point array (CR037.3) to the Astoria Bridge array (CR022.0) grouped by receiver of last detection at the Harrington Point array. Receiver CR037.3_01 was located closest to the Washington shore and receivers CR037.3_03 and CR037.3_04 were located on either side of the navigation channel. Sample sizes for each group are shown in each bar. Error bars denote one standard error. Dissimilar letters above each bar indicate a significant difference $(\alpha=0.05)$ from likelihood ratio tests.

The migration pathway used by subyearling Chinook salmon to migrate from Harrington Point (CR037.3) to the Astoria Bridge array (CR022.0) appeared to affect survival. Subyearling Chinook salmon that migrated from the Harrington Point receiver located nearest to the Washington shoreline (CR037.3_01), the majority of which migrated through Grays Bay, had a survival probability of 0.82 $(\mathrm{SE}=0.04)$, which was lower than the survival of fish that migrated from the receivers located nearer to the navigation channel (Figure 3.29). However, the probability of survival from Grays Bay (CR029.3, CR034.0_01, and CR034.0_02) to the Astoria Bridge was $0.93(\mathrm{SE}=0.02)$ for subyearling Chinook salmon detected by the receivers in Grays Bay. This indicates that much of the mortality incurred by subyearling Chinook salmon that migrated from the Harrington Point receiver located nearest to the Washington shoreline (CR037.3_01) occurred between the Harrington Point and Grays Bay receivers. The area located between these receivers is positioned directly north of Rice Island, is relatively small (3.3 $\mathrm{km}$ in length), and is characterized by shallow (less than $3 \mathrm{~m}$.) water. 


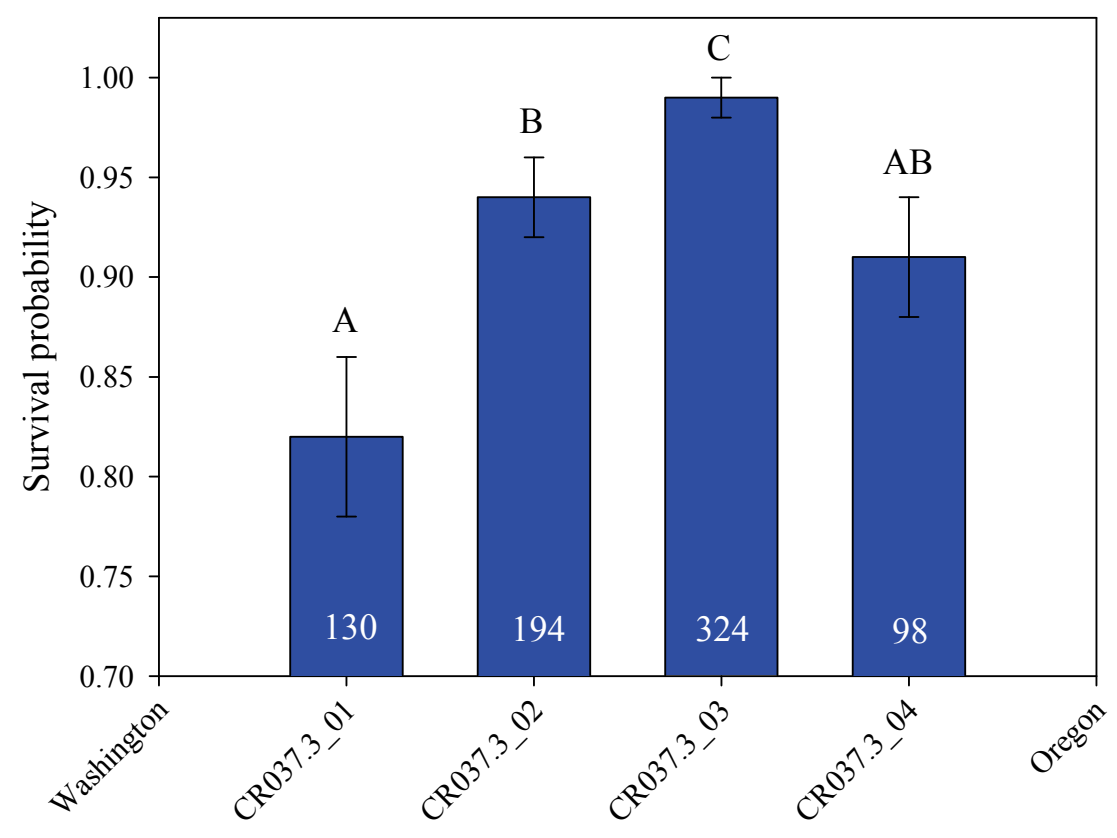

Harrington Point receiver

Figure 3.29. Survival probability of acoustic-tagged subyearling Chinook salmon from the Harrington Point array (CR037.3) to the Astoria Bridge array (CR022.0) grouped by receiver of last detection at the Harrington Point array. Receiver CR037.3 01 was located closest to the Washington shore and receivers CR037.3_03 and CR037.3_04 were located on either side of the navigation channel. Sample sizes for each group are shown in each bar. Error bars denote one standard error. Dissimilar letters above each bar indicate a significant difference $(\alpha=0.05)$ from likelihood ratio tests.

Yearling and subyearling Chinook salmon that migrated from the Harrington Point receiver located nearest to the Washington shoreline (CR037.3_01), the majority of which migrated through Grays Bay, had significantly longer travel times from Harrington Point to the Astoria Bridge (Figures 3.30 and 3.31) than fish that migrated from the remaining Harrington Point receivers. Yearling and subyearling Chinook salmon that migrated from Harrington Point closest to the navigation channel (CR037.3_03 and CR037.3_04) generally had the shortest travel times. Travel times of steelhead from Harrington Point to the Astoria Bridge were generally similar regardless of which Harrington Point receiver (surrogate for migration pathway) they were last detected (Figure 3.32). 


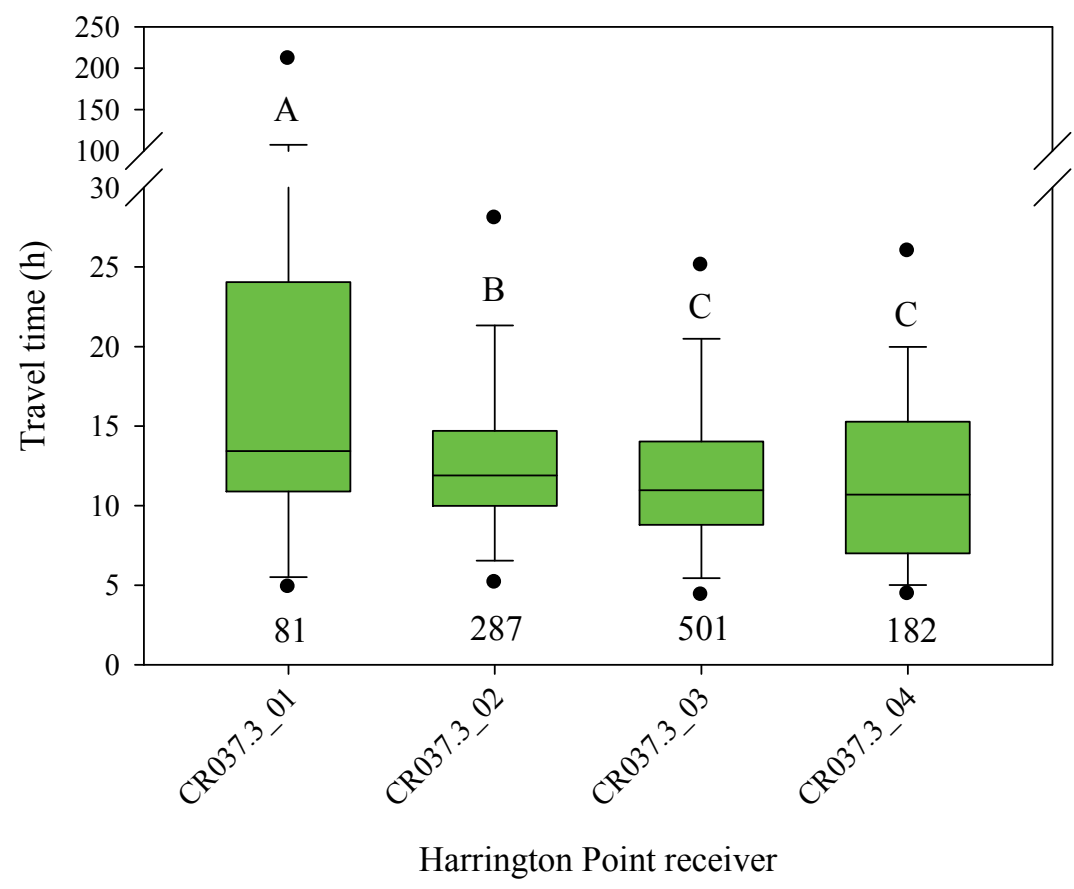

Figure 3.30. Travel time of acoustic-tagged yearling Chinook salmon from the Harrington Point array (CR037.3) to the Astoria Bridge array (CR022.0) grouped by receiver of last detection at the Harrington Point array. Receiver CR037.3 01 was located closest to the Washington shore and receivers CR037.3 03 and CR037.3 04 were located on either side of the navigation channel. Sample sizes for each group are shown below each box. Solid lines within the boxes represent medians, upper and lower limits of the box represent 25 th and 75 th percentiles, whiskers represent 10 th and 90th percentiles, and dots represent 5 th and 95th percentiles. 


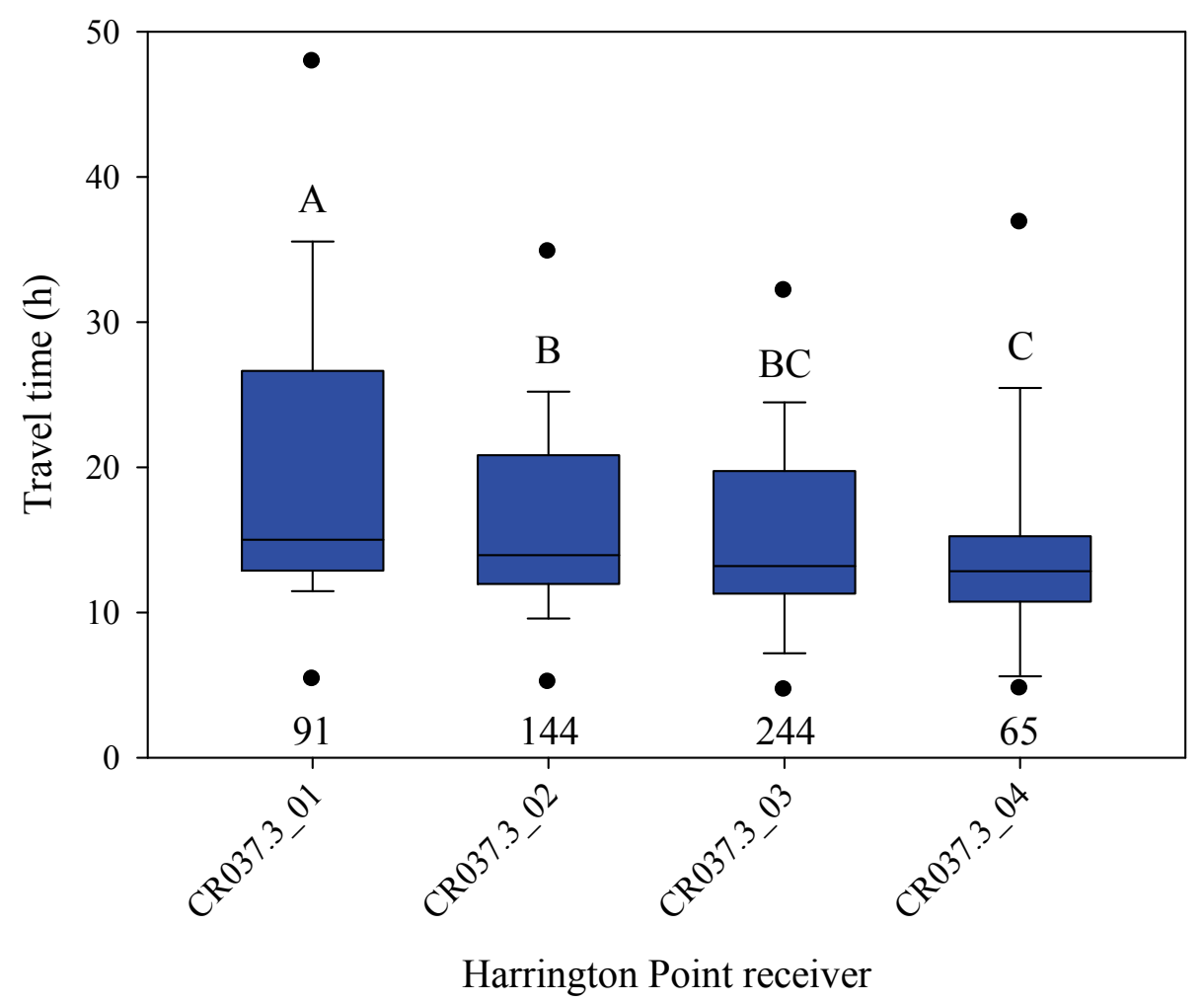

Figure 3.31. Travel time of acoustic-tagged subyearling Chinook salmon from the Harrington Point array (CR037.3) to the Astoria Bridge array (CR022.0) grouped by receiver of last detection at the Harrington Point array. Receiver CR037.3_01 was located closest to the Washington shore and receivers CR037.3_03 and CR037.3_04 were located on either side of the navigation channel. Sample sizes for each group are shown below each box. Solid lines within the boxes represent medians, upper and lower limits of the box represent 25 th and 75th percentiles, whiskers represent 10th and 90th percentiles, and dots represent 5 th and 95 th percentiles. 


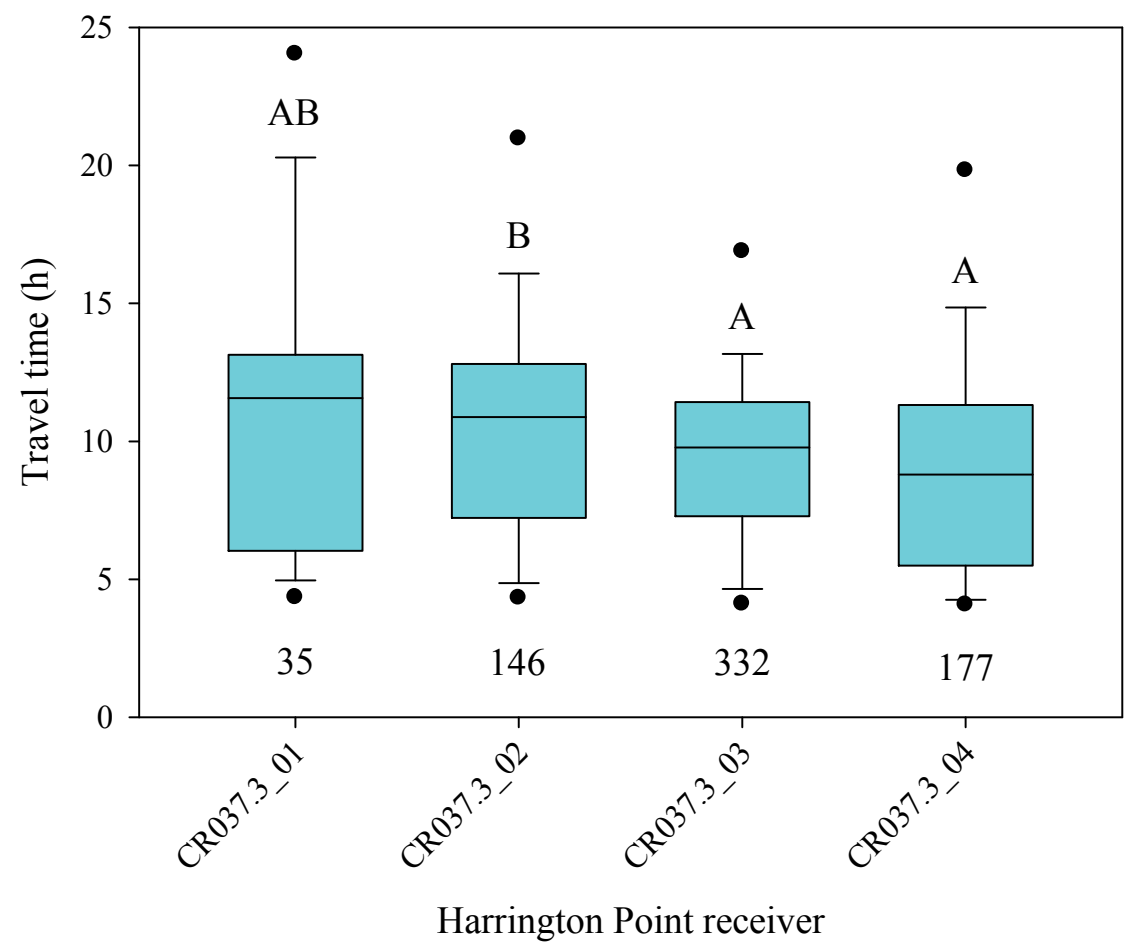

Figure 3.32. Travel time of acoustic-tagged steelhead from the Harrington Point array (CR037.3) to the Astoria Bridge array (CR022.0) grouped by receiver of last detection at the Harrington Point array. Receiver 01 was located closest to the Washington shore and receivers 03 and 04 were located on either side of the navigation channel. Sample sizes for each group are shown below each box. Solid lines within the boxes represent medians, upper and lower limits of the box represent 25 th and 75 th percentiles, whiskers represent 10 th and 90 th percentiles, and dots represent 5 th and 95 th percentiles.

\subsubsection{Cross-Channel Distribution}

The majority of yearling Chinook salmon were first detected in the Washington shoreline channel at the Astoria Bridge array (CR022.0; Figure 3.33). At the East Sand Island array (CR008.3), they were most frequently first detected around $2 \mathrm{~km}$ north of Clatsop Spit, halfway between the middle of the channel and the tip of West Sand Island (Figure 3.33). This area is in line with the end of a pile dike that extends out from East Sand Island (Figure 3.34). At the Columbia River Bar array (CR002.8), the largest percentages of yearling Chinook salmon were first detected south of the navigation channel (Figure 3.34).

The distribution of steelhead at the Astoria Bridge array (CR022.0) was similar to yearling Chinook salmon with the greatest percentage of steelhead first detected in the Washington shoreline channel (Figure 3.35). However, a greater percentage of steelhead was detected in the middle of the river and in the Oregon shoreline channel than observed for yearling Chinook salmon. At the East Sand Island array (CR008.3), steelhead were more often detected closer to Clatsop Spit (Oregon shoreline) than either yearling or subyearling Chinook salmon (Figure 3.35). At the Columbia River Bar array (CR002.8), the greatest percentage of steelhead was first detected on the Oregon side of the navigation channel (Figure 3.34). 

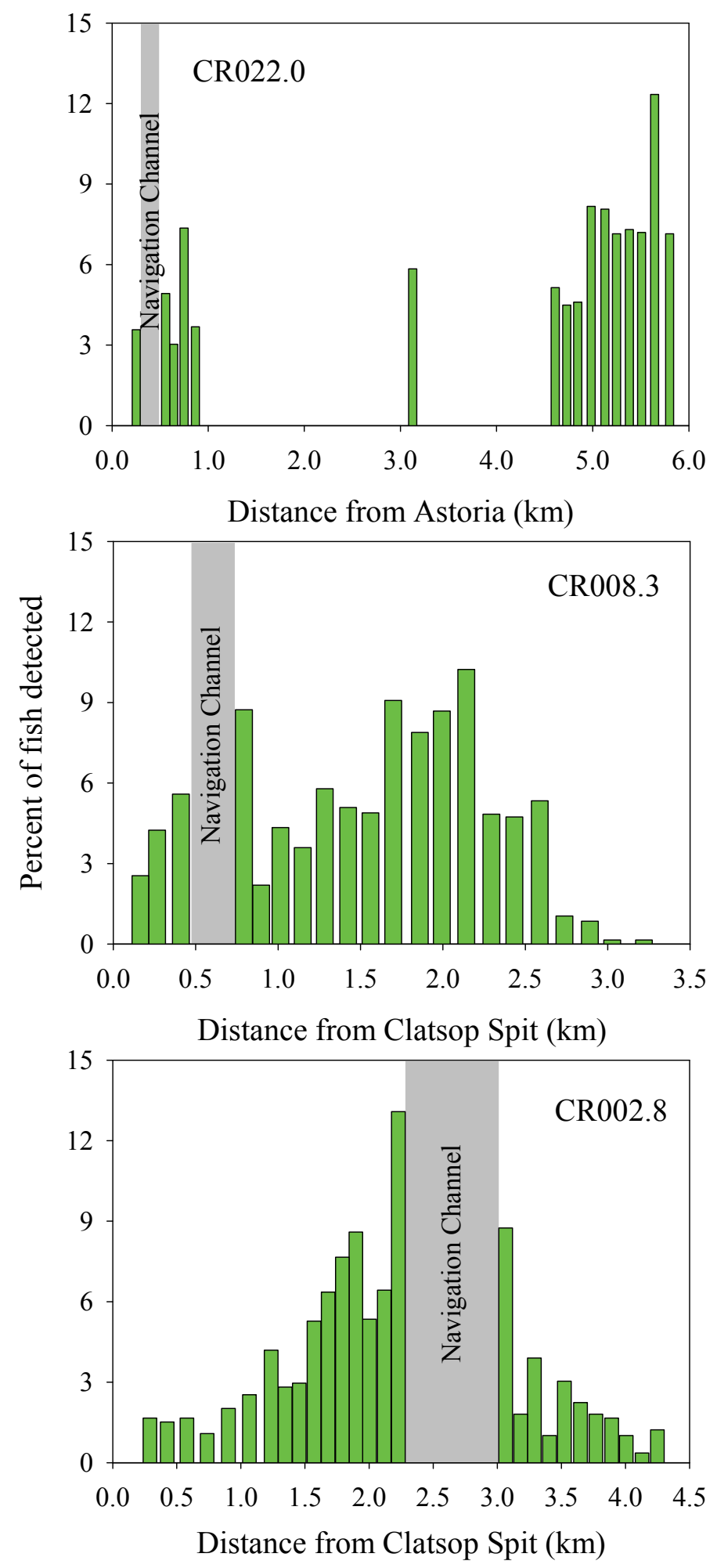

Figure 3.33. Cross-channel distribution of acoustic-tagged yearling Chinook salmon first detections at arrays at the Astoria Bridge (CR022.0), East Sand Island (CR008.3), and the Columbia River Bar (CR002.8). 


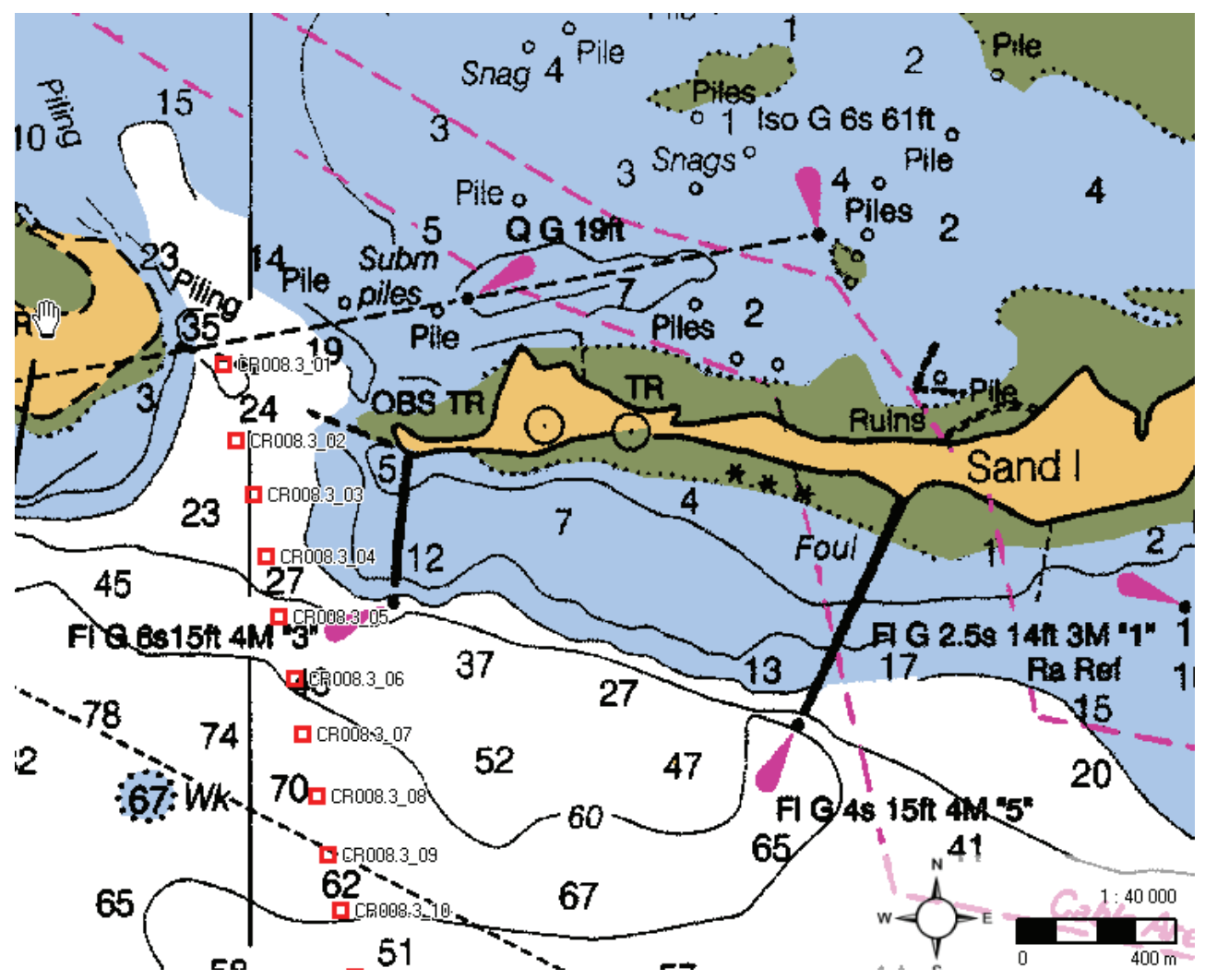

Figure 3.34. Detail of the CR008.3 array near East Sand Island showing the proximity of receiver positions to the pile dike that extends southward from the western tip of East Sand Island. For reference to cross-channel distribution figures, position CR008.3_05 is about $2.5 \mathrm{~km}$ from Clatsop Spit.

The distribution of steelhead at the Astoria Bridge array (CR022.0) was similar to yearling Chinook salmon with the greatest percentage of steelhead first detected in the Washington shoreline channel (Figure 3.35). However, a greater percentage of steelhead was detected in the middle of the river and in the Oregon shoreline channel than observed for yearling Chinook salmon. At the East Sand Island array (CR008.3), steelhead were more often detected closer to Clatsop Spit (Oregon shoreline) than either yearling or subyearling Chinook salmon (Figure 3.35). At the Columbia River Bar array (CR002.8), the greatest percentage of steelhead was first detected on the Oregon side of the navigation channel (Figure 3.35).

The cross-channel distribution of subyearling Chinook salmon at the Astoria Bridge array (CR022.0) was highly skewed towards the Washington shoreline, with the greatest percentage of first detections being in the Washington shoreline channel (Figure 3.36). The distribution of subyearling Chinook salmon at the East Sand Island array (CR008.3) was similar to that of yearling Chinook salmon with the greatest percentage of first detections occurring around 2.0 to $2.5 \mathrm{~km}$ north of Clatsop Spit (Figure 3.36). In contrast to the distributions of yearling Chinook salmon and steelhead, the majority of the subyearling Chinook salmon were first detected at the Columbia River Bar array (CR002.8) on the Washington side of the navigation channel (Figure 3.36). 

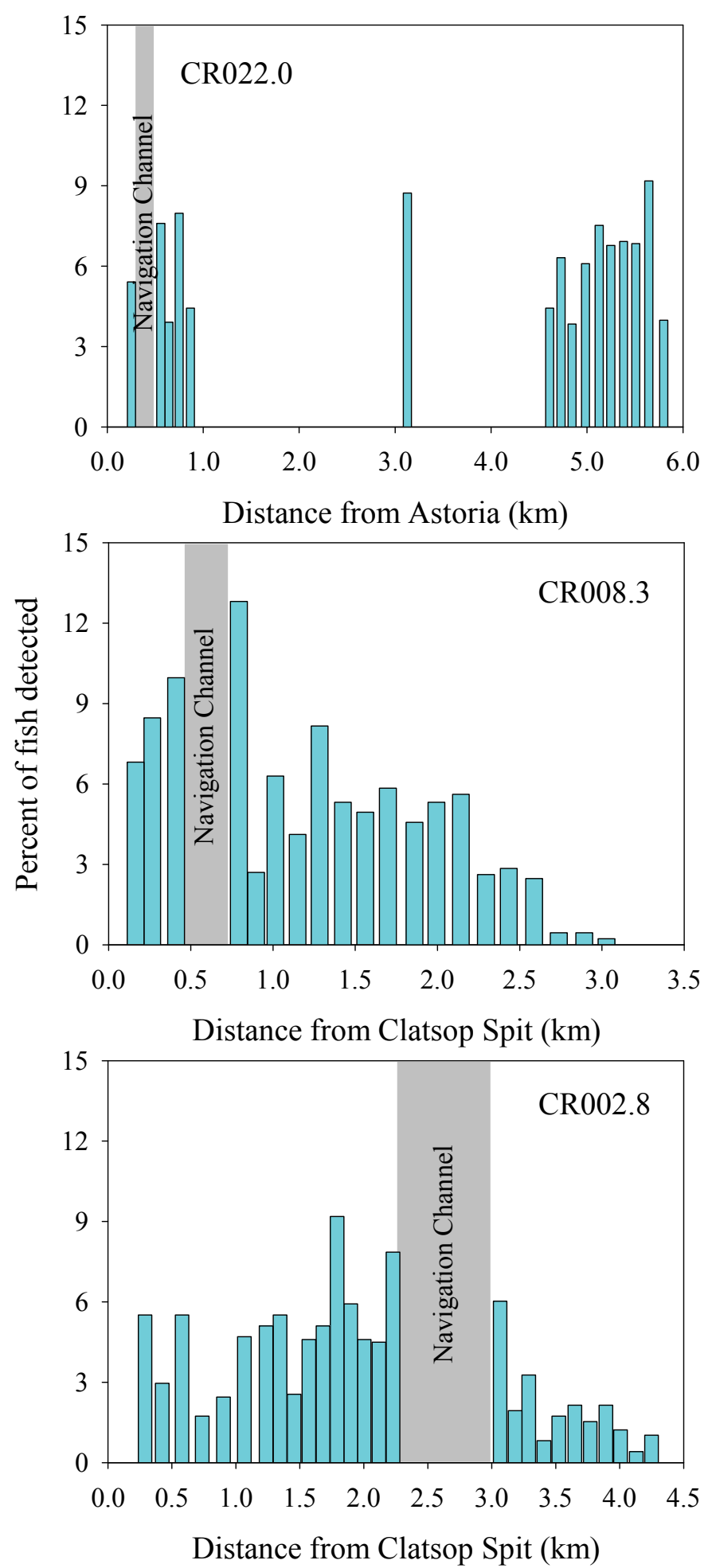

Figure 3.35. Cross-channel distribution of acoustic-tagged steelhead first detections at arrays at the Astoria Bridge (CR022.0), East Sand Island (CR008.3), and the Columbia River Bar (CR002.8). 

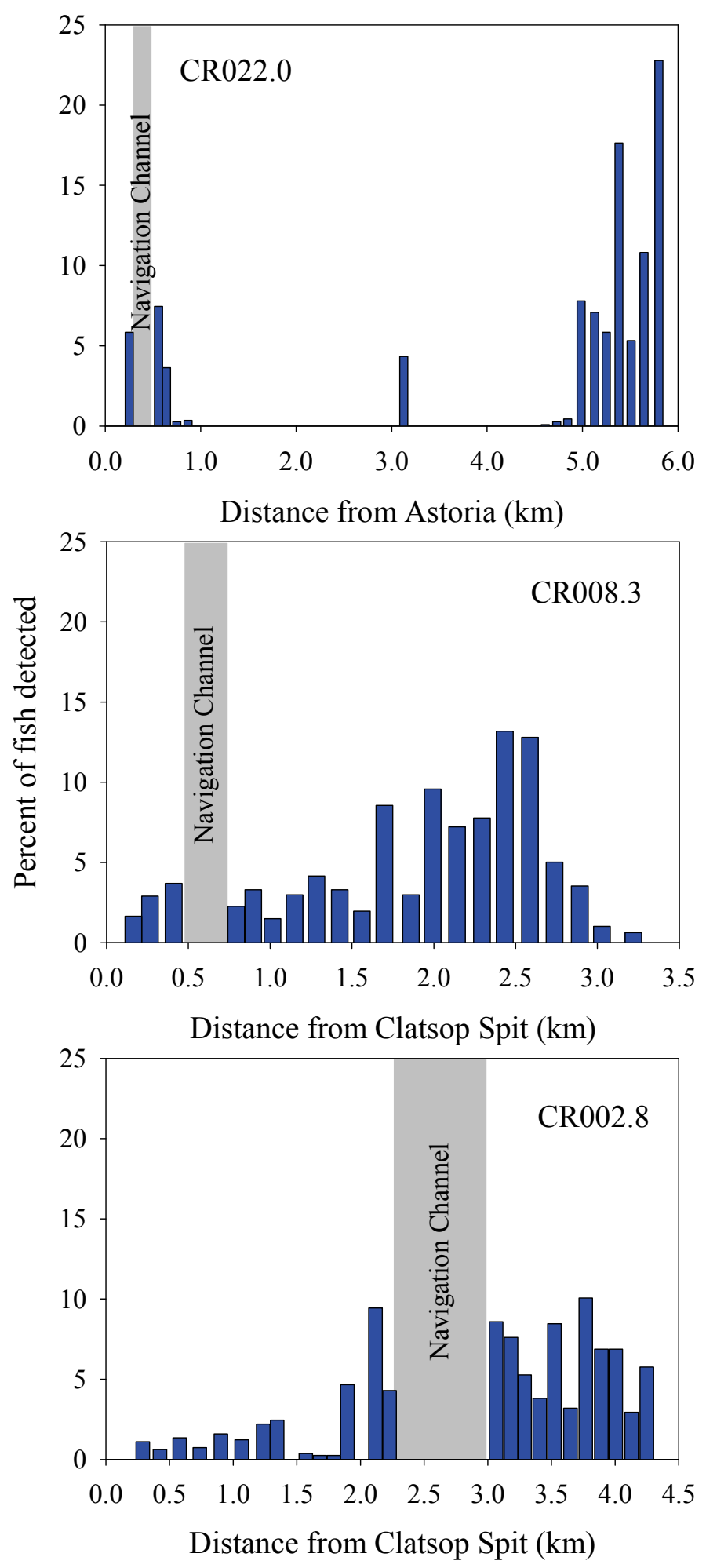

Figure 3.36. Cross-channel distribution of acoustic-tagged subyearling Chinook salmon detections at arrays at the Astoria Bridge (CR022.0), East Sand Island (CR008.3), and the Columbia River Bar (CR002.8). 


\subsubsection{Diel Distribution}

Yearling Chinook salmon were detected nearly equally throughout the day at the Three Tree Point (CR049.6) and Harrington Point (CR037.3) arrays (Figure 3.37). At the Astoria Bridge array (CR022.0), yearling Chinook salmon were more likely to be detected in the early morning, with detections declining throughout the daylight period and stabilizing around 3\% during hours of darkness (Figure 3.37). First detections of yearling Chinook salmon at the East Sand Island array (CR008.3) peaked in the early morning hours, with a smaller peak in the late afternoon (Figure 3.37). A similar pattern was observed at the Columbia River Bar array (CR002.8), though the peaks were less distinct (Figure 3.37).
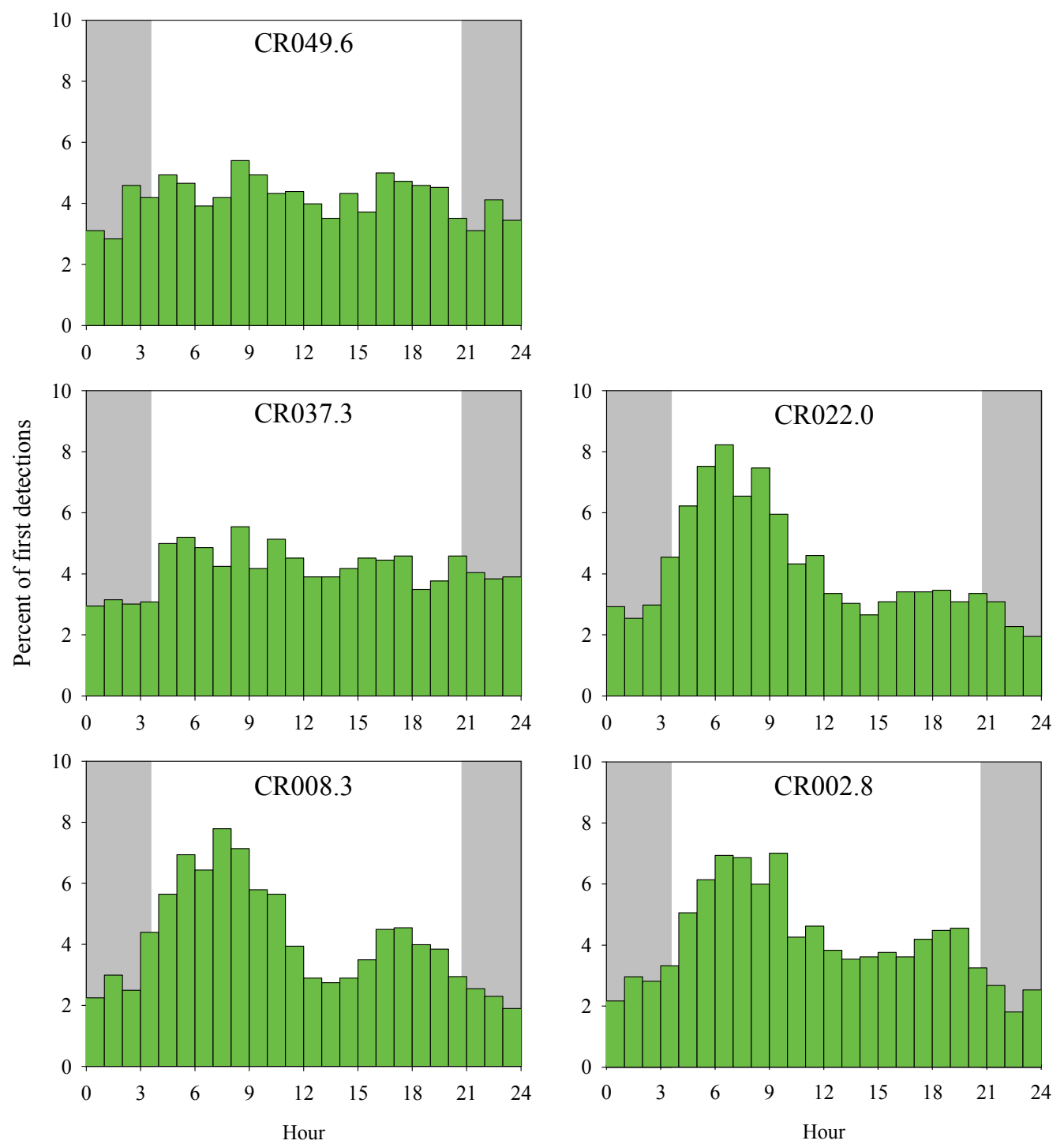

Figure 3.37. Hourly distributions of first detections of yearling Chinook salmon at Columbia River arrays at Three Tree Point (CR049.6), Harrington Point (CR037.3), Astoria Bridge (CR022.0), East Sand Island (CR008.3), and Columbia River Bar (CR002.8). Grey bars represent approximate hours of darkness. 
The highest percentage of steelhead first detections occurred in the late afternoon at the Three Tree Point array (CR049.6; Figure 3.38). At the Harrington Point array (CR037.3) there was a smaller peak in the early morning and a larger peak of first detections in the evening (Figure 3.38). At the Astoria Bridge array (CR022.0) the majority of steelhead were detected between 5 and 9 a.m., with detections declining throughout the day (Figure 3.38). The hourly distributions at the East Sand Island (CR008.3) and Columbia River Bar (CR002.8) arrays were similar to that at CR037.3 with peaks in the morning and evening (Figure 3.38).
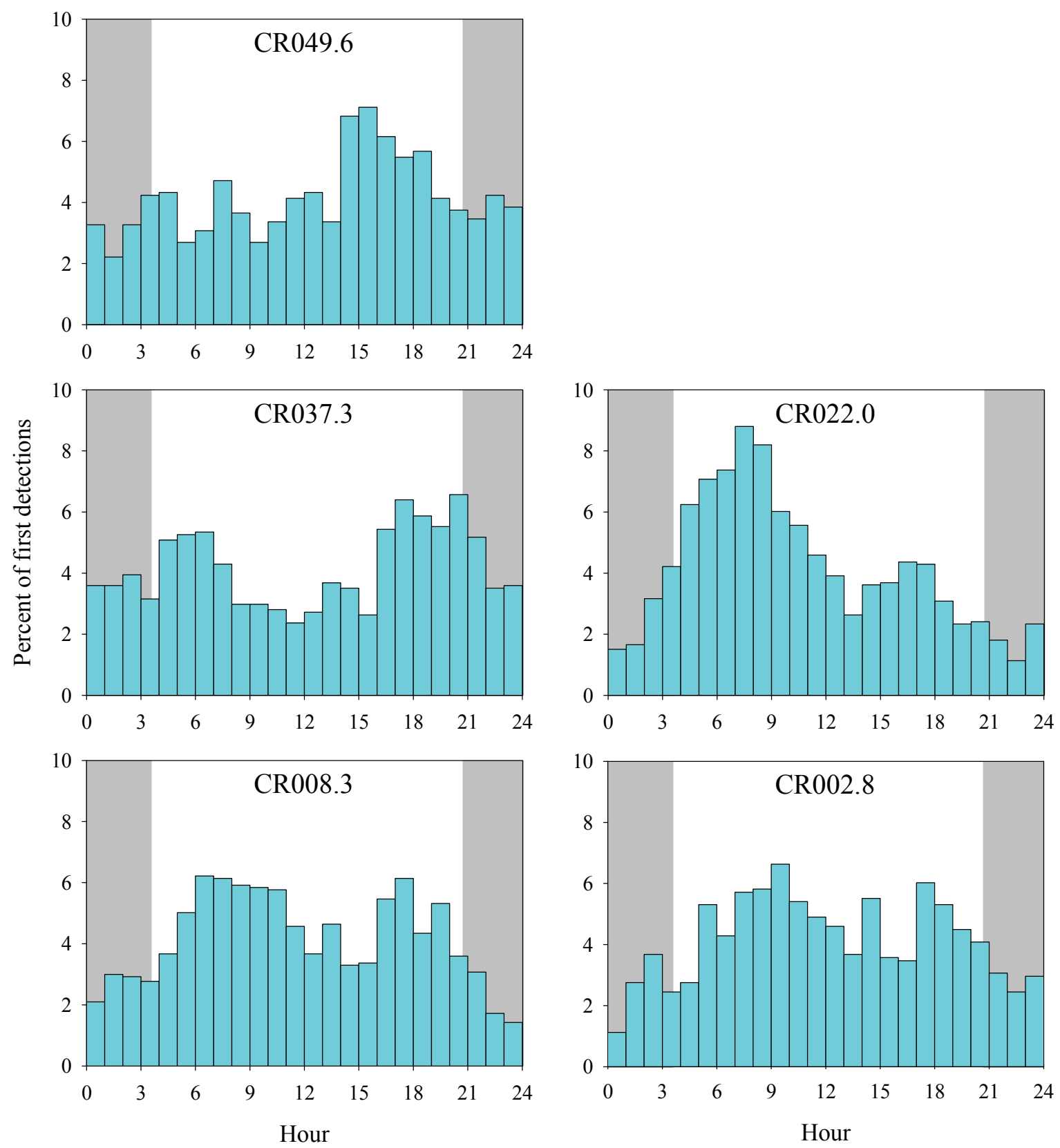

Figure 3.38. Hourly distributions of steelhead first detections at Columbia River arrays at Three Tree Point (CR049.6), Harrington Point (CR037.3), Astoria Bridge (CR022.0), East Sand Island (CR008.3), and Columbia River Bar (CR002.8). Grey bars represent approximate hours of darkness. 
The percentage of subyearling Chinook salmon first detections peaked in mid-morning and evening at all arrays (Figure 3.39). The lowest percentage of first detections of subyearling Chinook salmon was during early afternoon at all arrays.
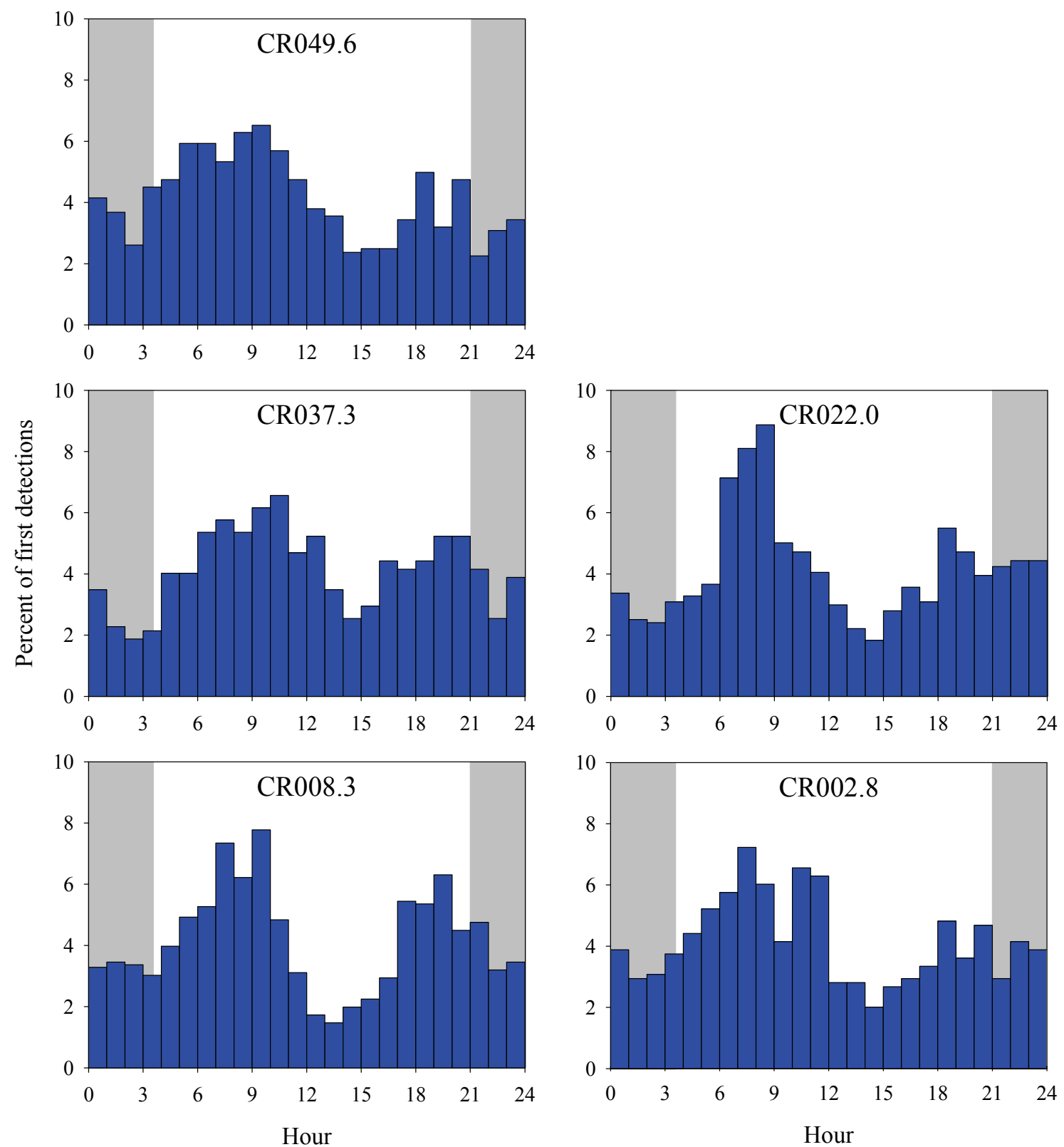

Figure 3.39. Hourly distributions of subyearling Chinook salmon first detections at Columbia River arrays at Three Tree Point (CR049.6), Harrington Point (CR037.3), Astoria Bridge (CR022.0), East Sand Island (CR008.3), and Columbia River Bar (CR002.8). Grey bars represent approximate hours of darkness. 


\subsubsection{Diel Distribution with Tide}

Analyses of the percentage of first detections by virtual release week against the average tide height during the time when the majority of fish were passing an array revealed that the timing of arrival at most arrays was influenced more by tide than by time of day for all species and runs (Figures 3.40 through 3.54). This relationship was most evident at arrays located closer to the mouth of the river (Astoria Bridge [CR022.0], East Sand Island [CR008.3], and Columbia River Bar [CR002.8]) and when the difference between high and low tide was greatest. Analysis of the percentage of first detections against change in tide height at the time of detection confirmed these results, indicating that all species or run types were most frequently first detected at all arrays downstream of rkm 50 during ebb tides (Figures 3.55, 3.56, and 3.57). 


\section{CR049.6}
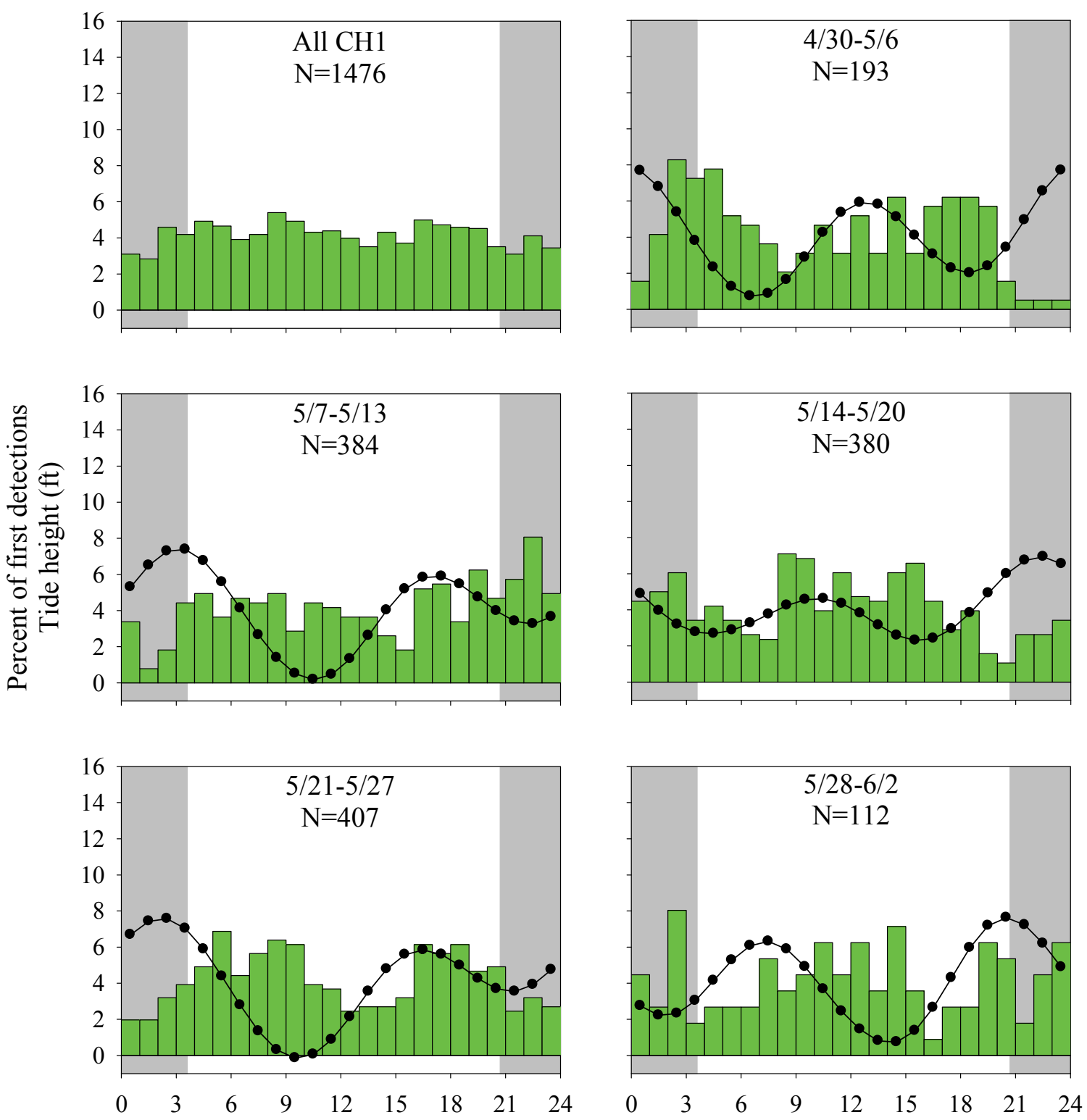

$\square$ \% CH1 Detections
$\longrightarrow \quad$ Tide Height $(\mathrm{ft})$

Hour

Figure 3.40. Hourly distribution at the Three Tree Point array (CR049.6) for all yearling Chinook salmon (top left panel). The rest of the panels show hourly distributions of 5 groups of yearling Chinook salmon (based on virtual release week at Bonneville Dam) and average hourly tide stage in feet at array CR049.6 on the Columbia River. The average tide stage was calculated using the estimated tide at Knappa Slough for each hour during the days in which the middle $80 \%$ of the fish from each virtual release were first detected at array CR049.6. 


\section{CR037.3}
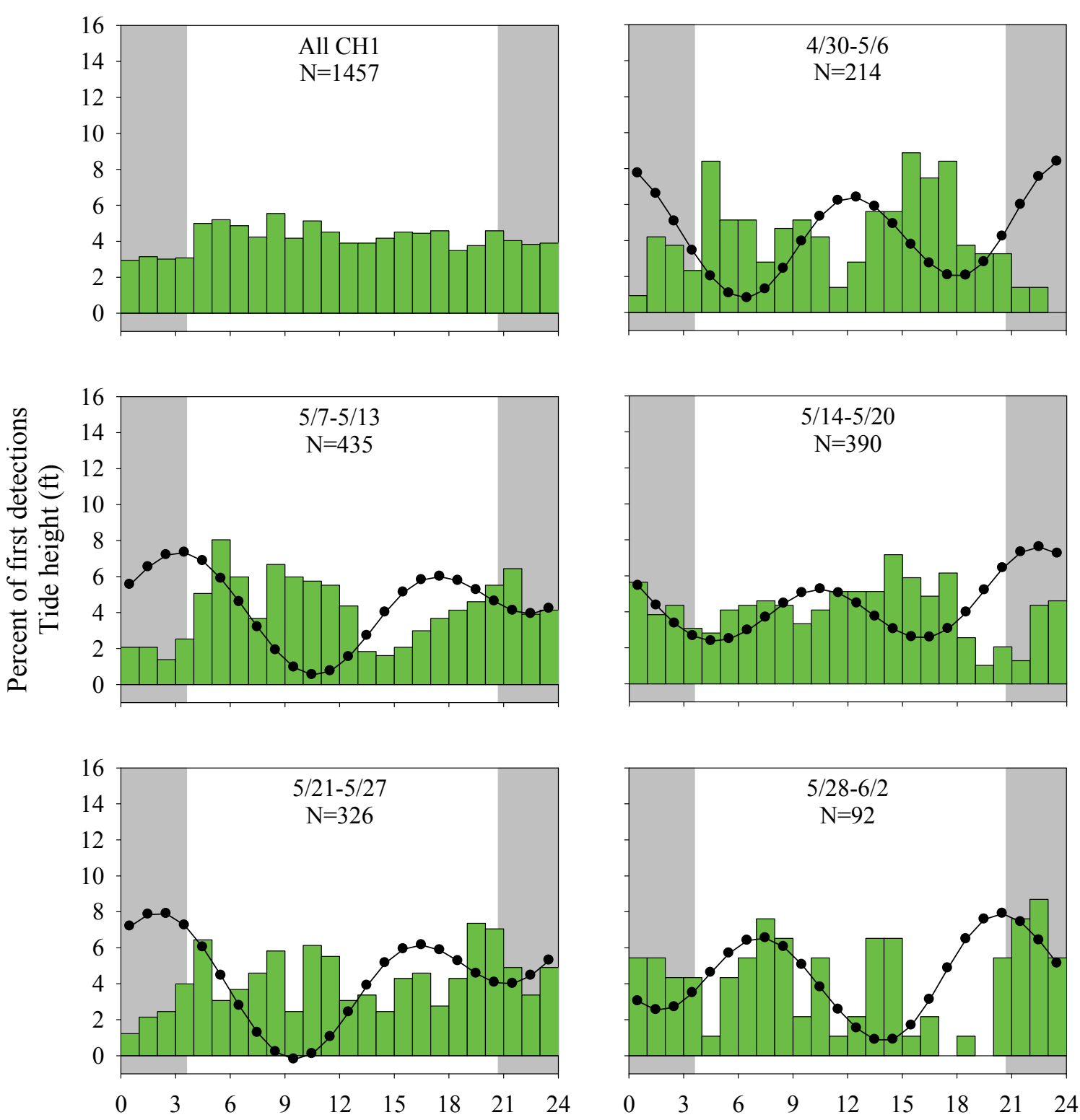

Hour

Figure 3.41. Hourly distribution at the Harrington Point array (CR037.3) for all yearling Chinook salmon (top left panel). The rest of the panels show hourly distributions of 5 groups of yearling Chinook salmon (based on virtual release week at Bonneville Dam) and average hourly tide stage in feet at array CR037.3 on the Columbia River. The average tide stage was calculated using the estimated tide at Harrington Point for each hour during the days in which the middle $80 \%$ of the fish from each virtual release were first detected at array CR037.3. 
CR022.0
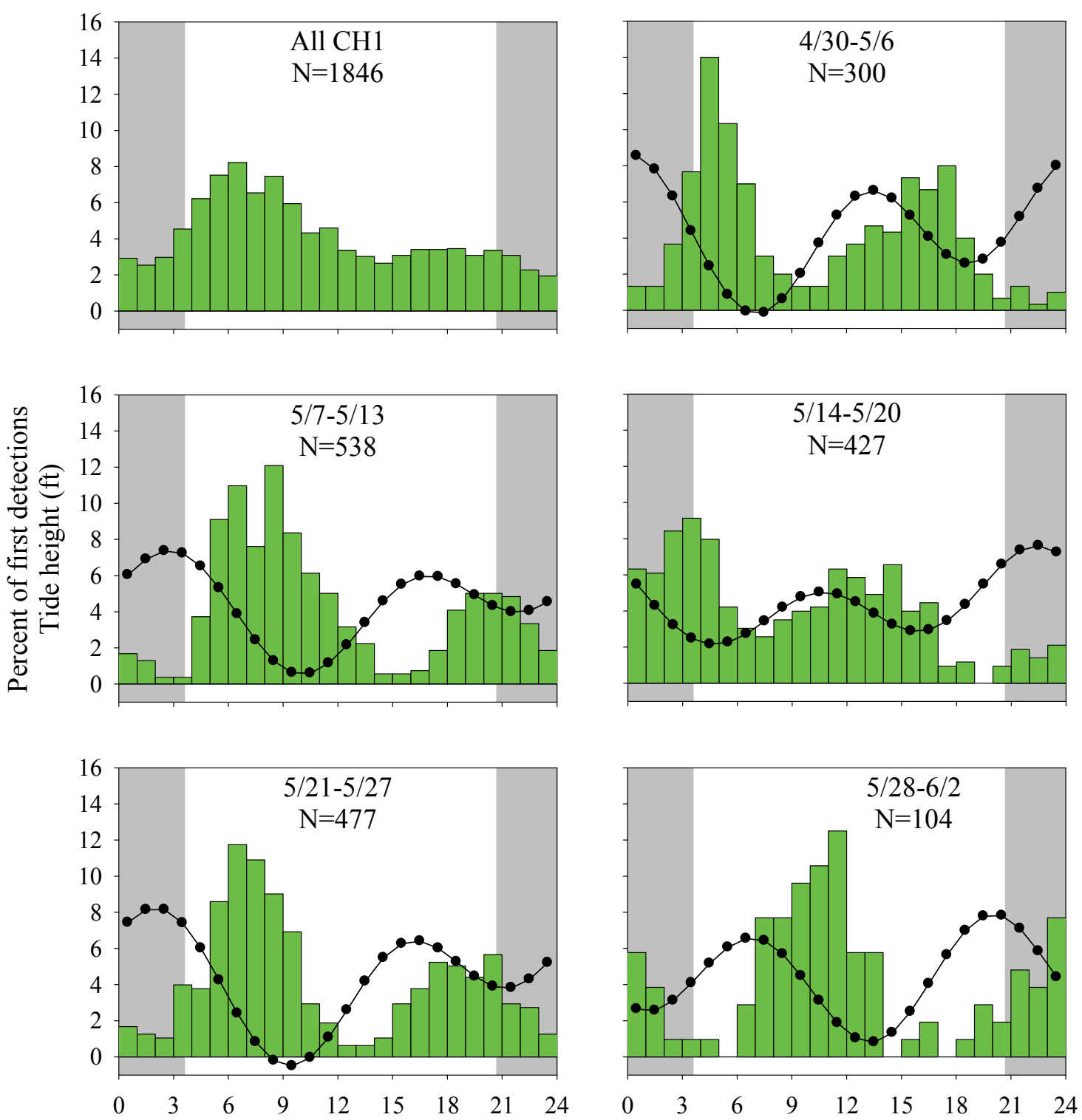

\% CH1 Detections

Hour

$\longrightarrow$ Tide Height (ft)

Figure 3.42. Hourly distribution at the Astoria Bridge array (CR022.0) for all yearling Chinook salmon (top left panel). The rest of the panels show hourly distributions of 5 groups of yearling Chinook salmon (based on virtual release week at Bonneville Dam) and average hourly tide stage in feet at array CR022.0 on the Columbia River. The average tide stage was calculated using the estimated tide at Astoria (Port Docks) for each hour during the days in which the middle $80 \%$ of the fish from each virtual release were first detected at array CR022.0. 


\section{CR008.3}
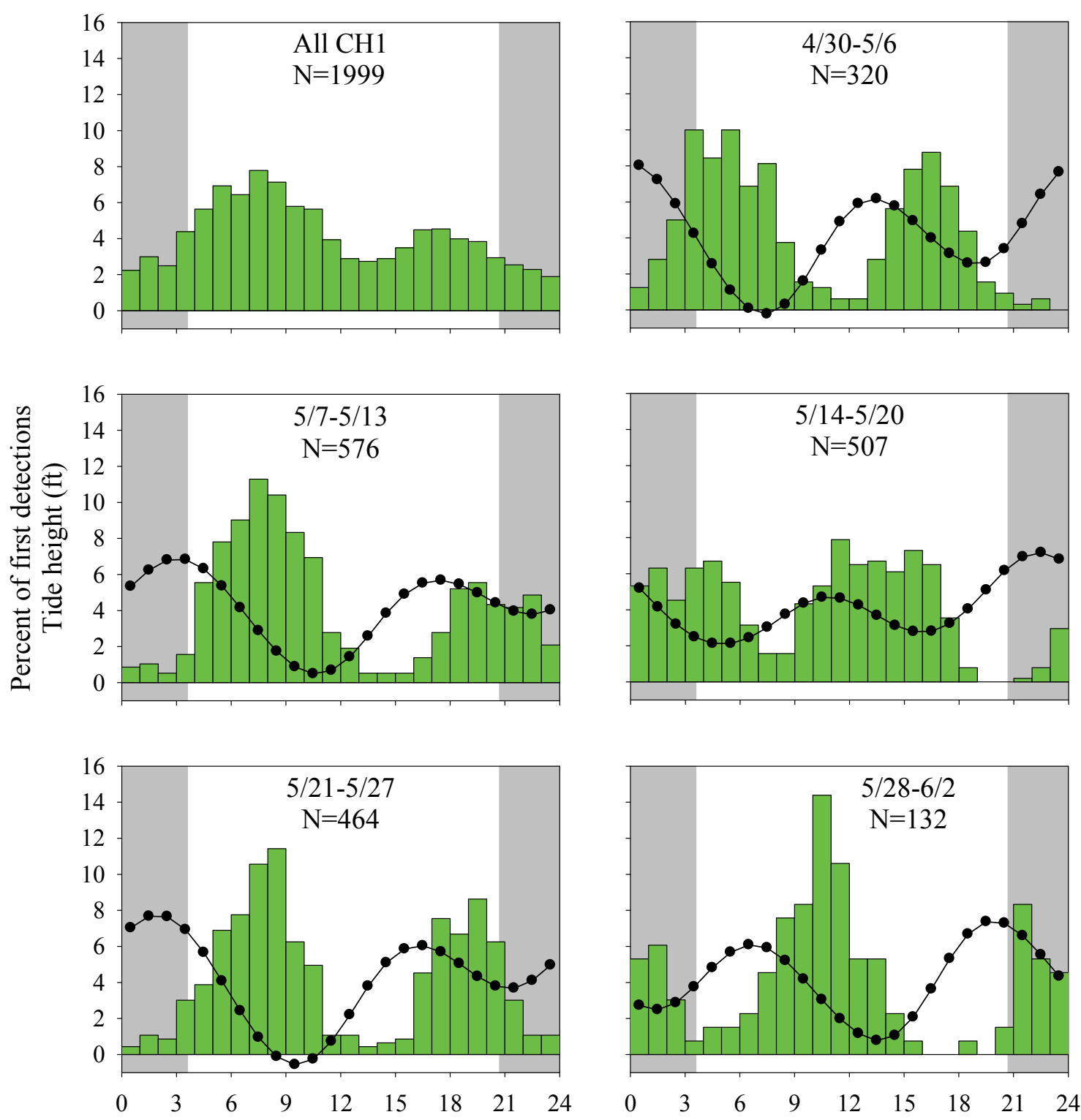

Hour $\longleftarrow$ \% CH1 Detections
$\longrightarrow \quad$ Tide Height $(\mathrm{ft})$

Figure 3.43. Hourly distribution at the East Sand Island array (CR008.3) for all yearling Chinook salmon (top left panel). The rest of the panels show hourly distributions of 5 groups of yearling Chinook salmon (based on virtual release week at Bonneville Dam) and average hourly tide stage in feet at array CR008.3 on the Columbia River. The average tide stage was calculated using the estimated tide at Chinook for each hour during the days in which the middle $80 \%$ of the fish from each virtual release were first detected at array CR008.3. 


\section{CR002.8}
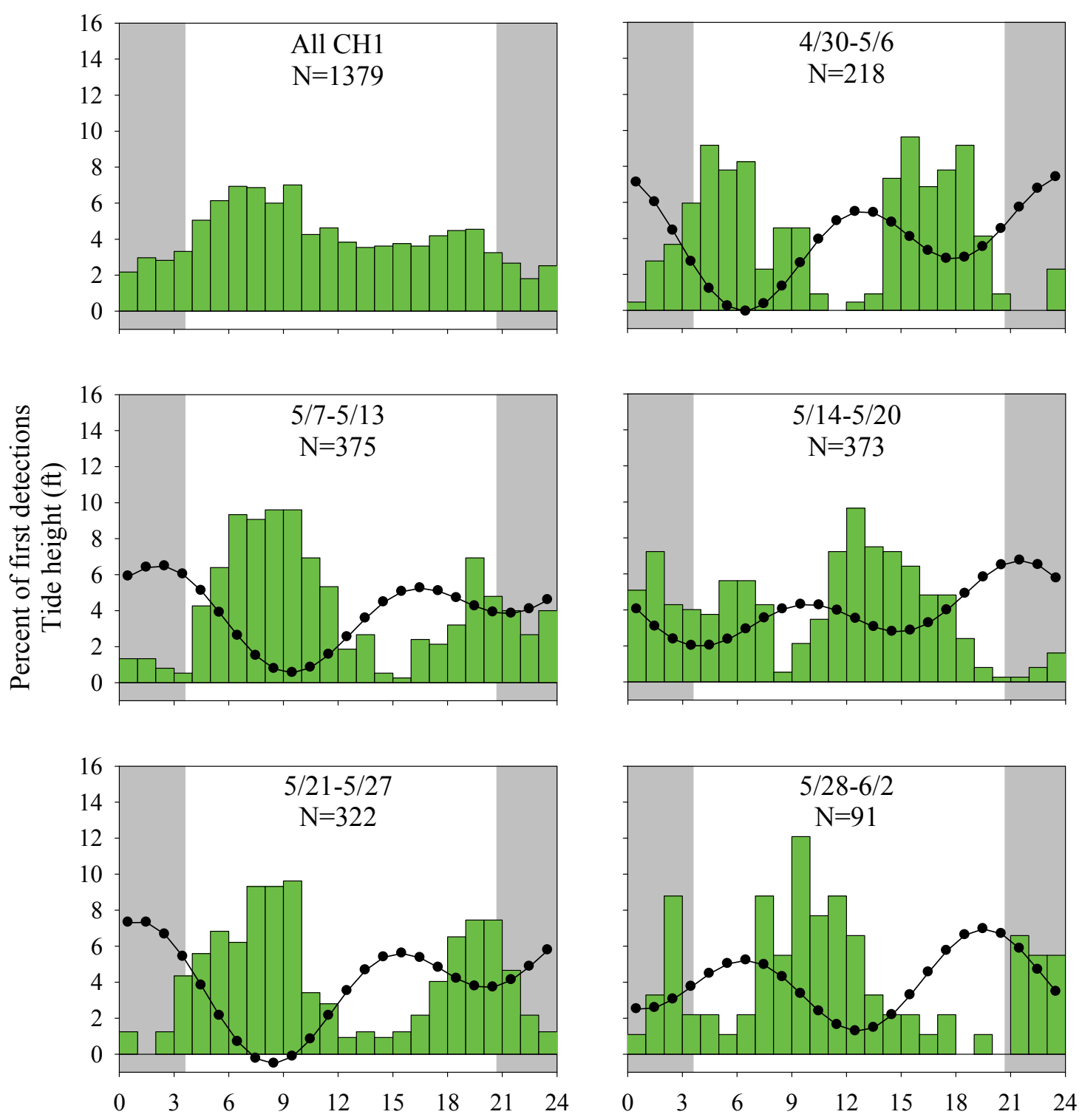

Hour

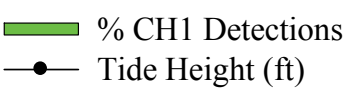

Figure 3.44. Hourly distribution at the Columbia River Bar array (CR002.8) for all yearling Chinook salmon (top left panel). The rest of the panels show hourly distributions of 5 groups of yearling Chinook salmon (based on virtual release week at Bonneville Dam) and average hourly tide stage in feet at array CR002.8 on the Columbia River. The average tide stage was calculated using estimated tide at the North Jetty for each hour during the days in which the middle $80 \%$ of the fish from each virtual release were first detected at array CR002.8. 


\section{CR049.6}
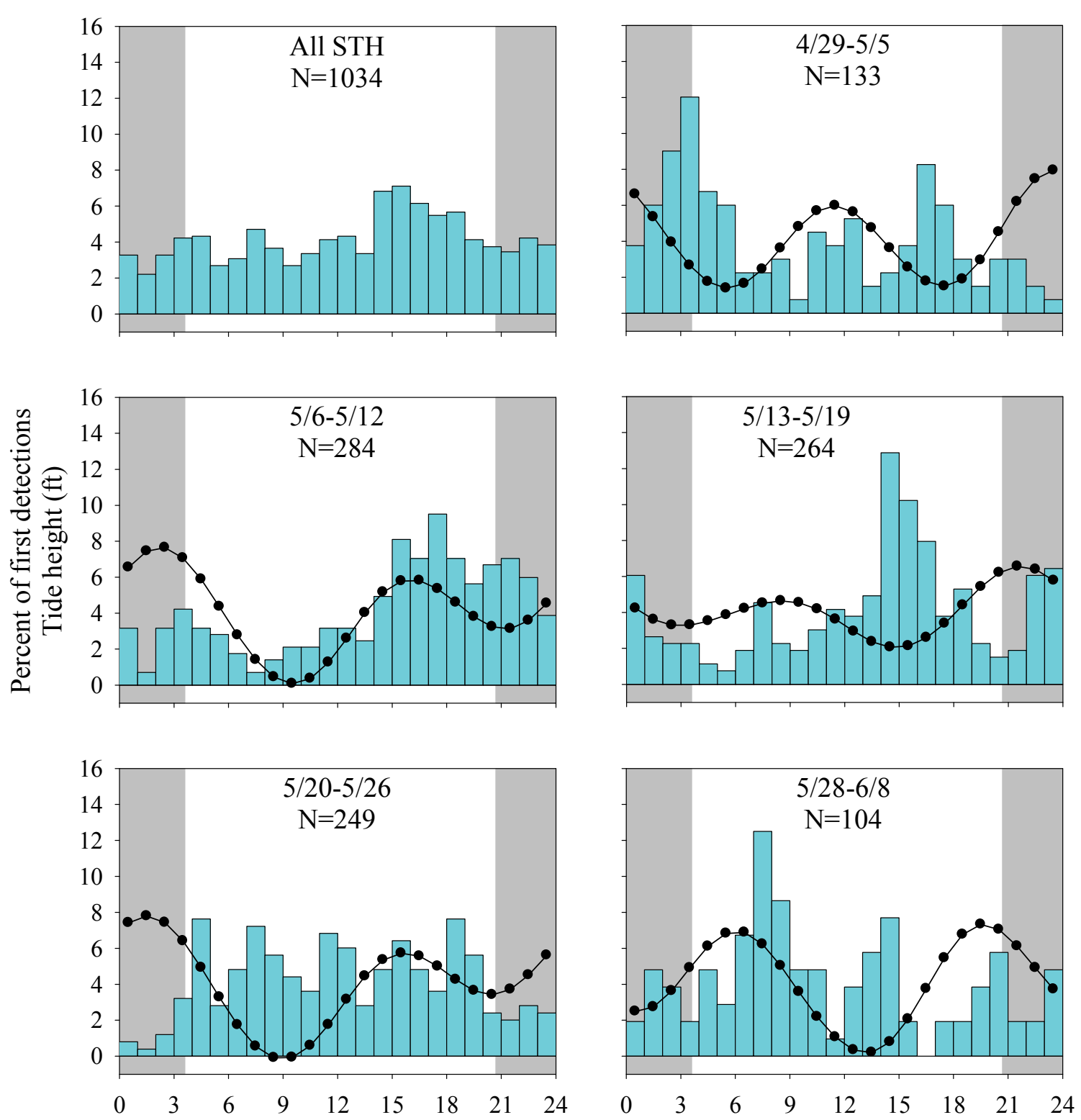

$\longleftarrow$ \% STH Detections
$\longrightarrow$ Tide Height $(\mathrm{ft})$

Hour

Figure 3.45. Hourly distribution at the Three Tree Point array (CR049.6) for all steelhead (top left panel). The rest of the panels show hourly distributions of 5 groups of steelhead (based on virtual release week at Bonneville Dam) and average hourly tide stage in feet at array CR049.6 on the Columbia River. The average tide stage was calculated using estimated tide at Knappa Slough for each hour during the days in which the middle $80 \%$ of the fish from each virtual release were first detected at array CR049.6. 


\section{CR037.3}
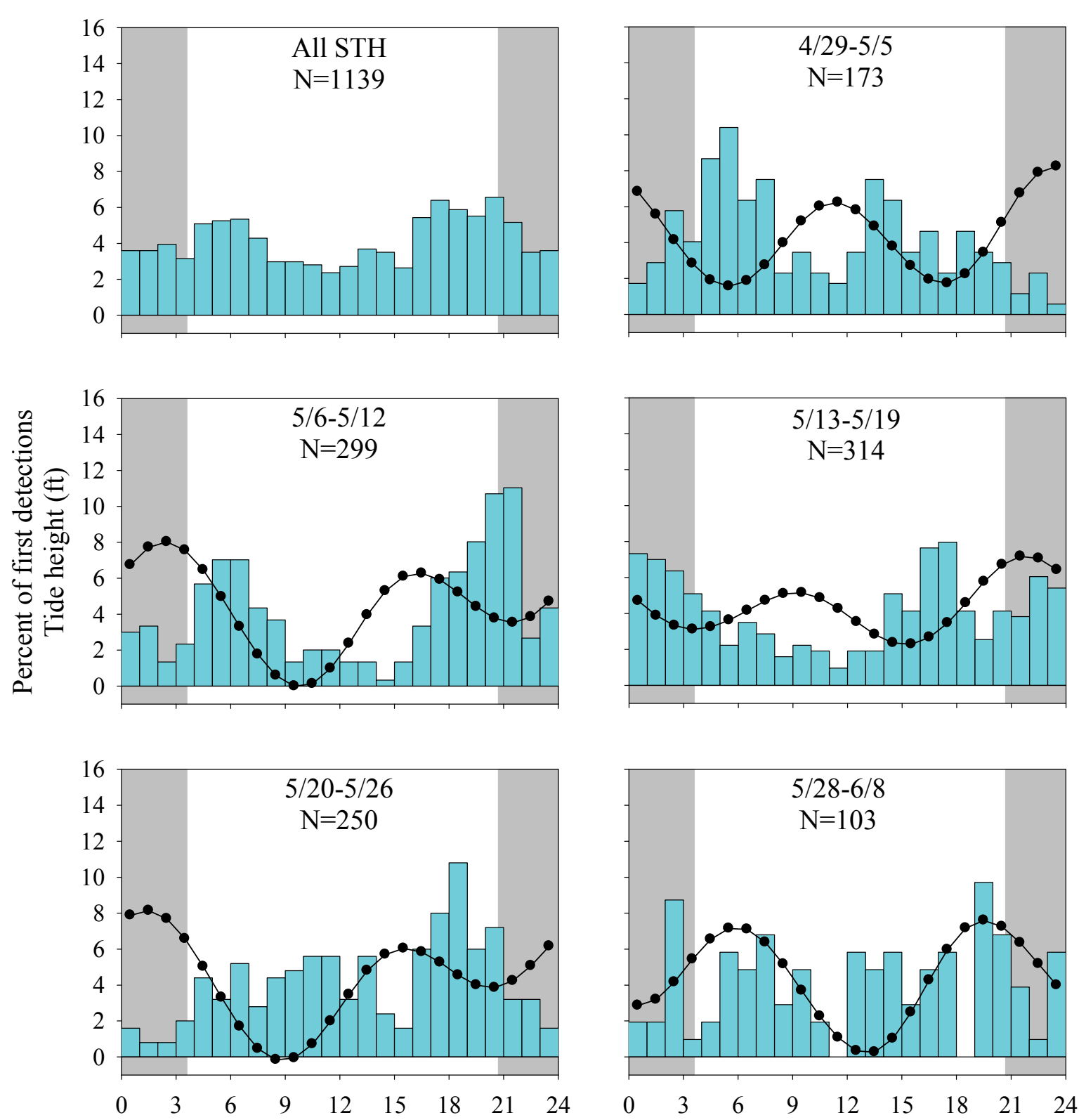

\% STH Detections

Hour

$\longrightarrow$ Tide Height (ft)

Figure 3.46. Hourly distribution at the Harrington Point array (CR037.3) for all steelhead (top left panel). The rest of the panels show hourly distributions of 5 groups of steelhead (based on virtual release week at Bonneville Dam) and average hourly tide stage in feet at array CR037.3 on the Columbia River. The average tide stage was calculated using estimated tide at Harrington Point for each hour during the days in which the middle $80 \%$ of the fish from each virtual release were first detected at array CR037.3. 
CR022.0
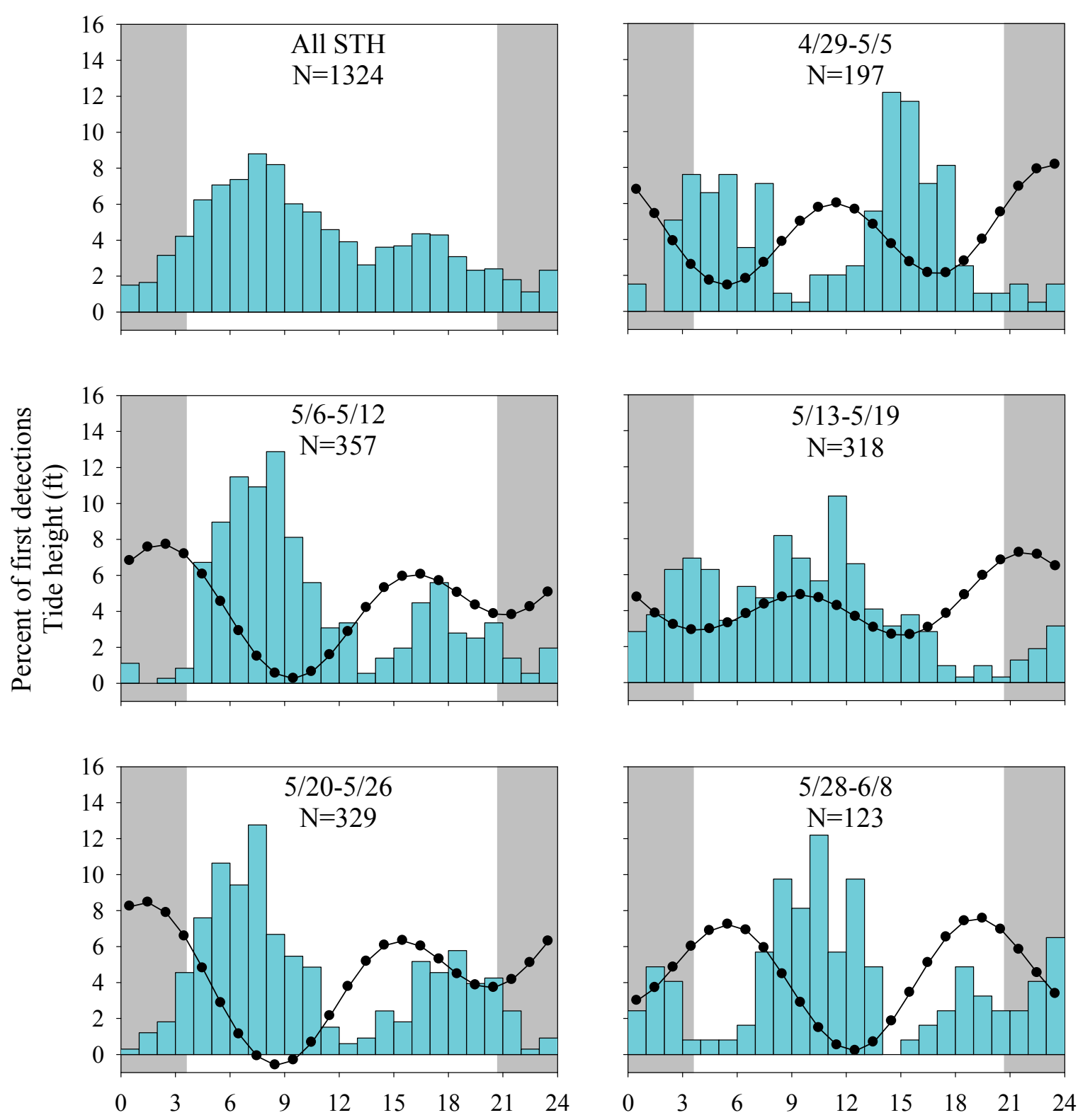

Hour

$\square \%$ STH Detections

$\longrightarrow$ Tide Height (ft)

Figure 3.47. Hourly distribution at the Astoria Bridge array (CR022.0) for all steelhead (top left panel). The rest of the panels show hourly distributions of 5 groups of steelhead (based on virtual release week at Bonneville Dam) and average hourly tide stage in feet at array CR022.0 on the Columbia River. The average tide stage was calculated using estimated tide at Astoria (Port Docks) for each hour during the days in which the middle $80 \%$ of the fish from each virtual release were first detected at array CR022.0. 


\section{CR008.3}
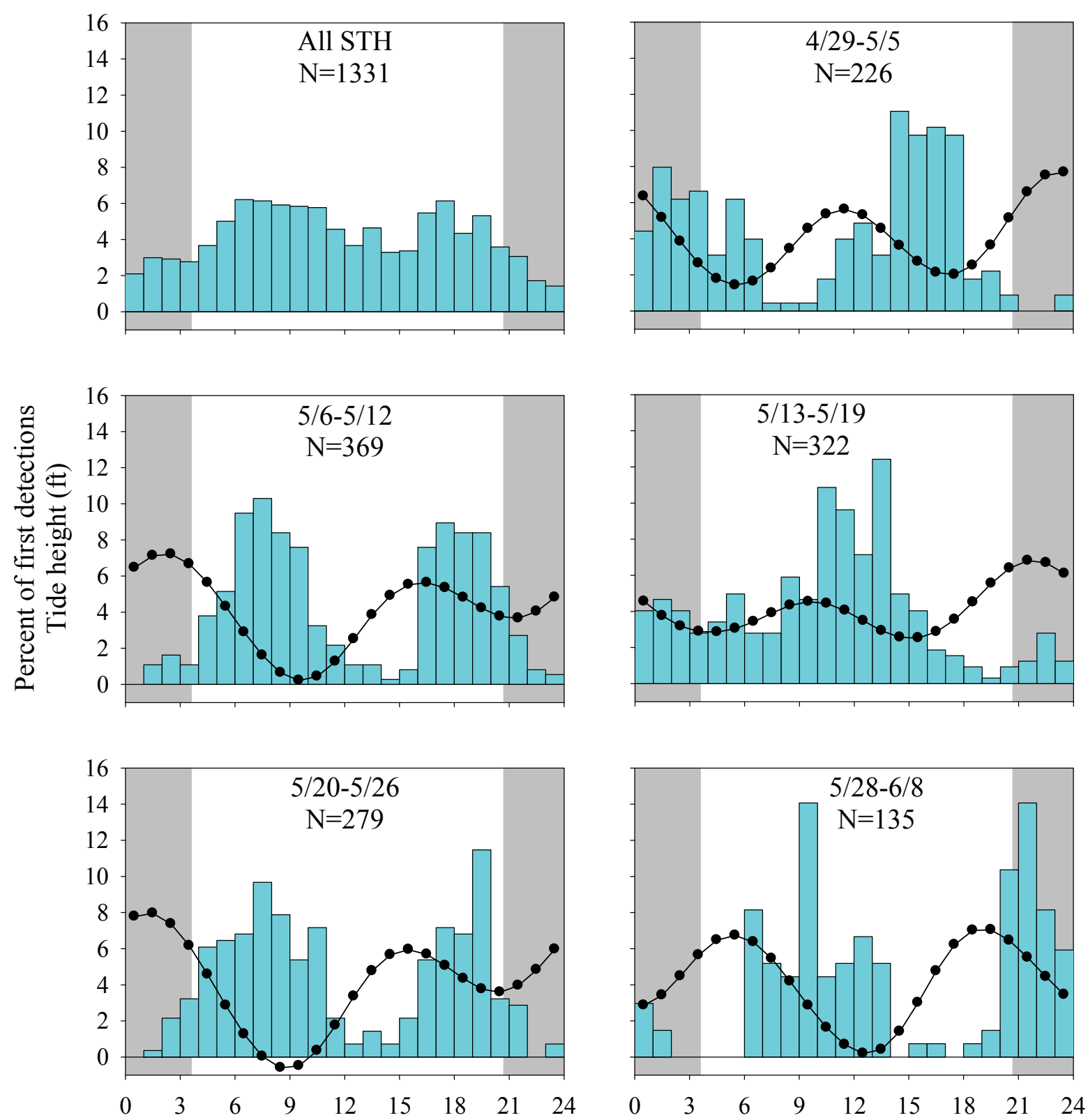

Hour $\longrightarrow$ \% STH Detection
$\longrightarrow \quad$ Tide Height $(\mathrm{ft})$

Figure 3.48. Hourly distribution at the East Sand Island array (CR008.3) for all steelhead (top left panel). The rest of the panels show hourly distributions of 5 groups of steelhead (based on virtual release week at Bonneville Dam) and average hourly tide stage in feet at array CR008.3 on the Columbia River. The average tide stage was calculated using estimated tide at Chinook for each hour during the days in which the middle $80 \%$ of the fish from each virtual release were first detected at array CR008.3. 


\section{CR002.8}
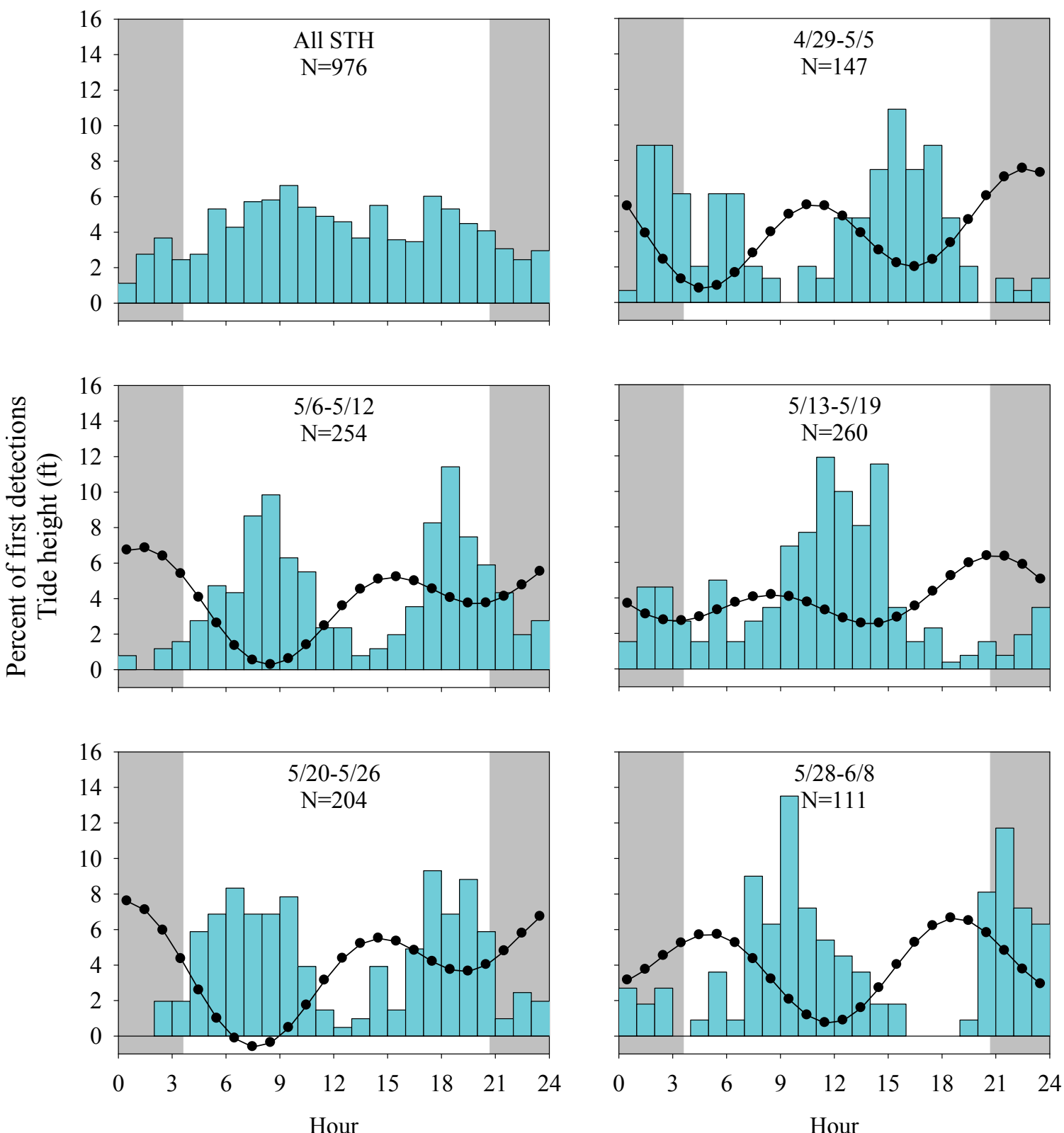

\section{$\square \%$ STH Detections \\ $\longrightarrow$ Tide Height (ft)}

Figure 3.49. Hourly distribution at the Columbia River Bar array (CR002.8) for all steelhead (top left panel). The rest of the panels show hourly distributions of 5 groups of steelhead (based on virtual release week at Bonneville Dam) and average hourly tide stage in feet at array CR002.8 on the Columbia River. The average tide stage was calculated using estimated tide at the North Jetty for each hour during the days in which the middle $80 \%$ of the fish from each virtual release were first detected at array CR002.8. 


\section{CR049.6}
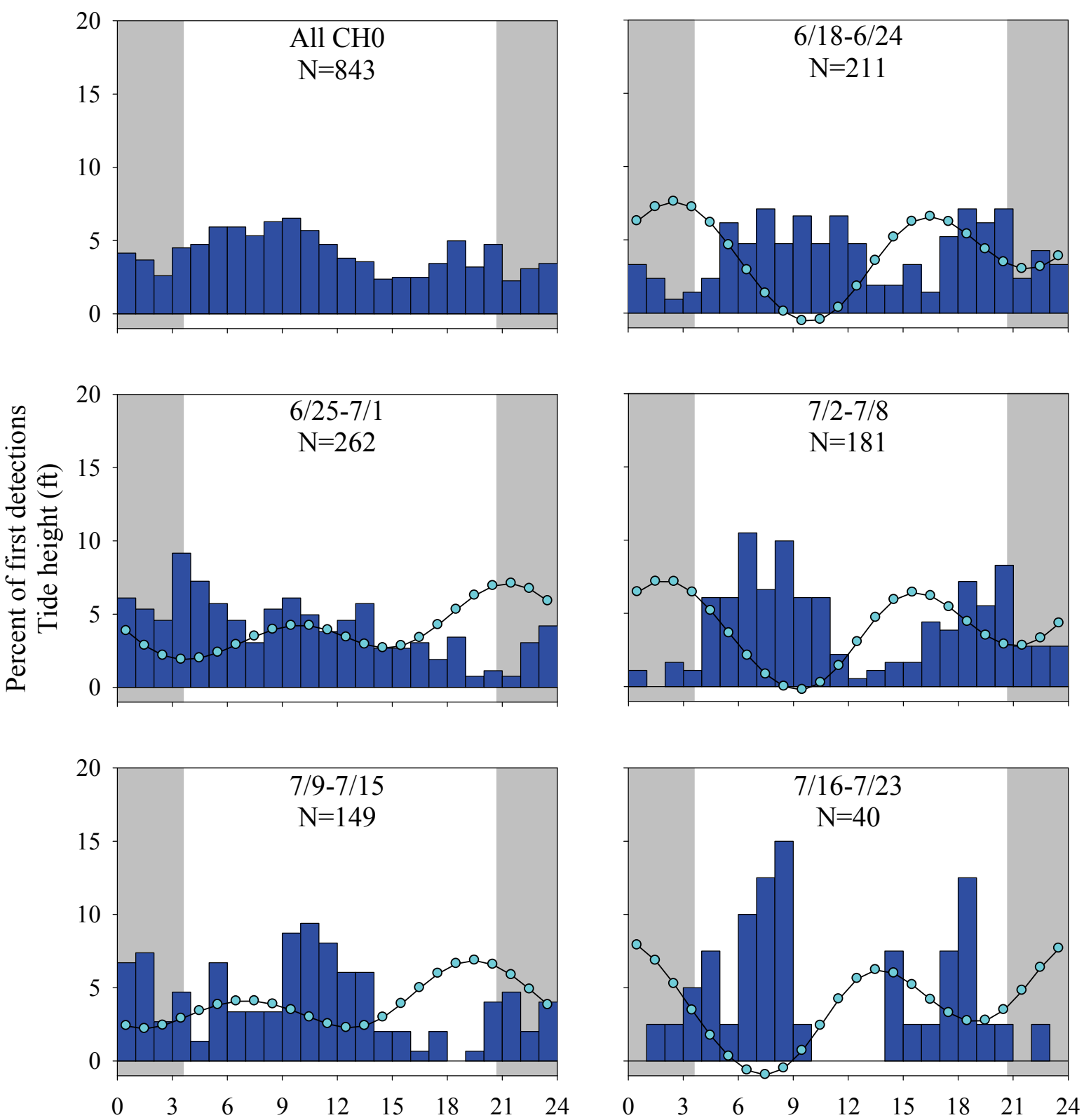

Hour \% CH0 Detections
$\ldots$ Tide Height $(\mathrm{ft})$

Figure 3.50. Hourly distribution at the Three Tree Point array (CR049.6) for all subyearling Chinook salmon (top left panel). The rest of the panels show hourly distributions of 5 groups of subyearling Chinook salmon (based on virtual release week at Bonneville Dam) and average hourly tide stage in feet at array CR049.6 on the Columbia River. The average tide stage was calculated using the estimated tide at Knappa Slough for each hour during the days in which the middle $80 \%$ of the fish from each virtual release were first detected at array CR049.6. 


\section{CR037.3}
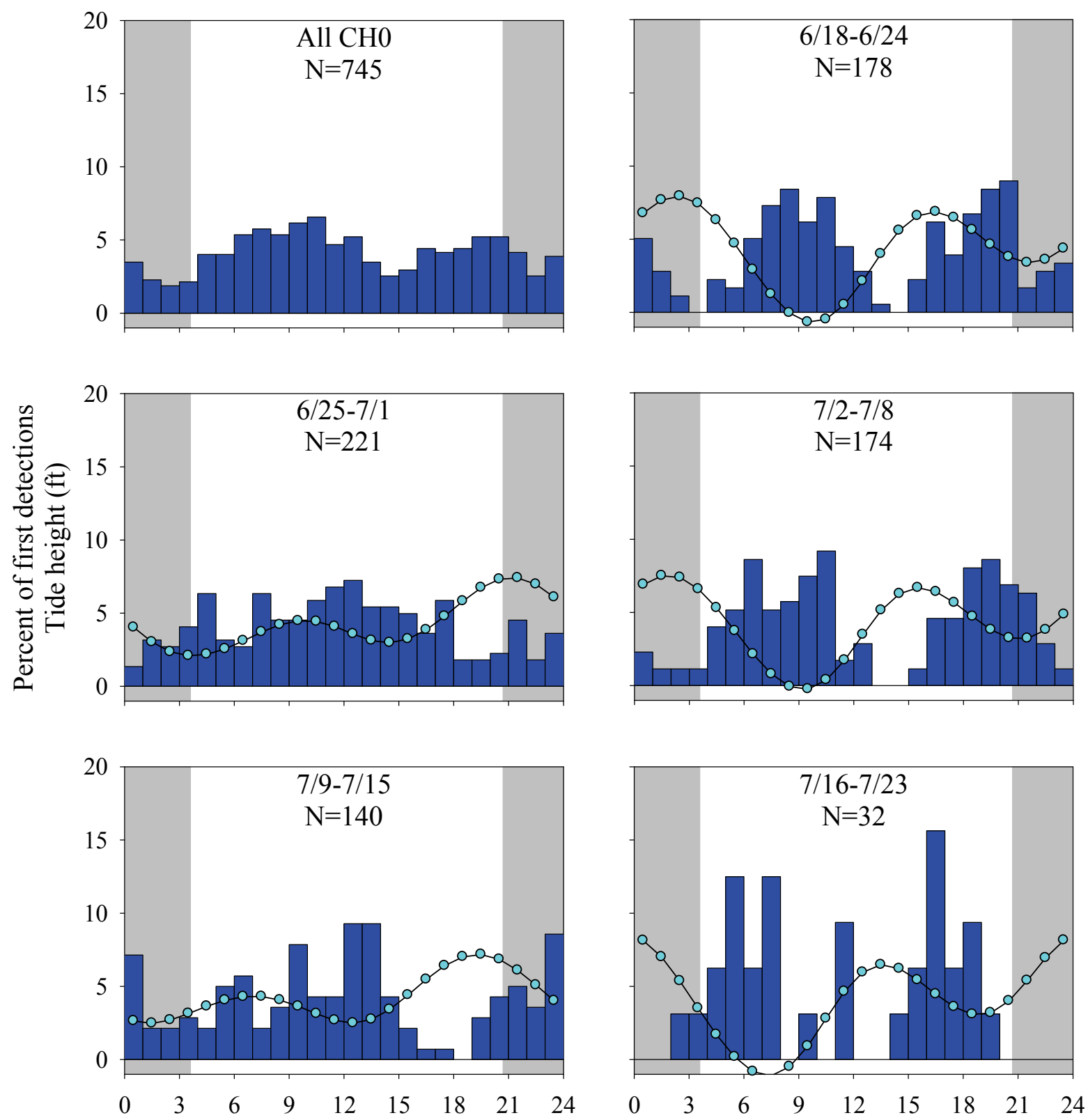

Hour

$\% \mathrm{CH} 0$ Detections

$\multimap$ Tide Height (ft)

Figure 3.51. Hourly distribution at the Harrington Point array (CR037.3) for all subyearling Chinook salmon (top left panel). The rest of the panels show hourly distributions of 5 groups of subyearling Chinook salmon (based on virtual release week at Bonneville Dam) and average hourly tide stage in feet at array CR037.3 on the Columbia River. The average tide stage was calculated using the estimated tide at Harrington Point for each hour during the days in which the middle $80 \%$ of the fish from each virtual release were first detected at array CR037.3. 


\section{CR022.0}
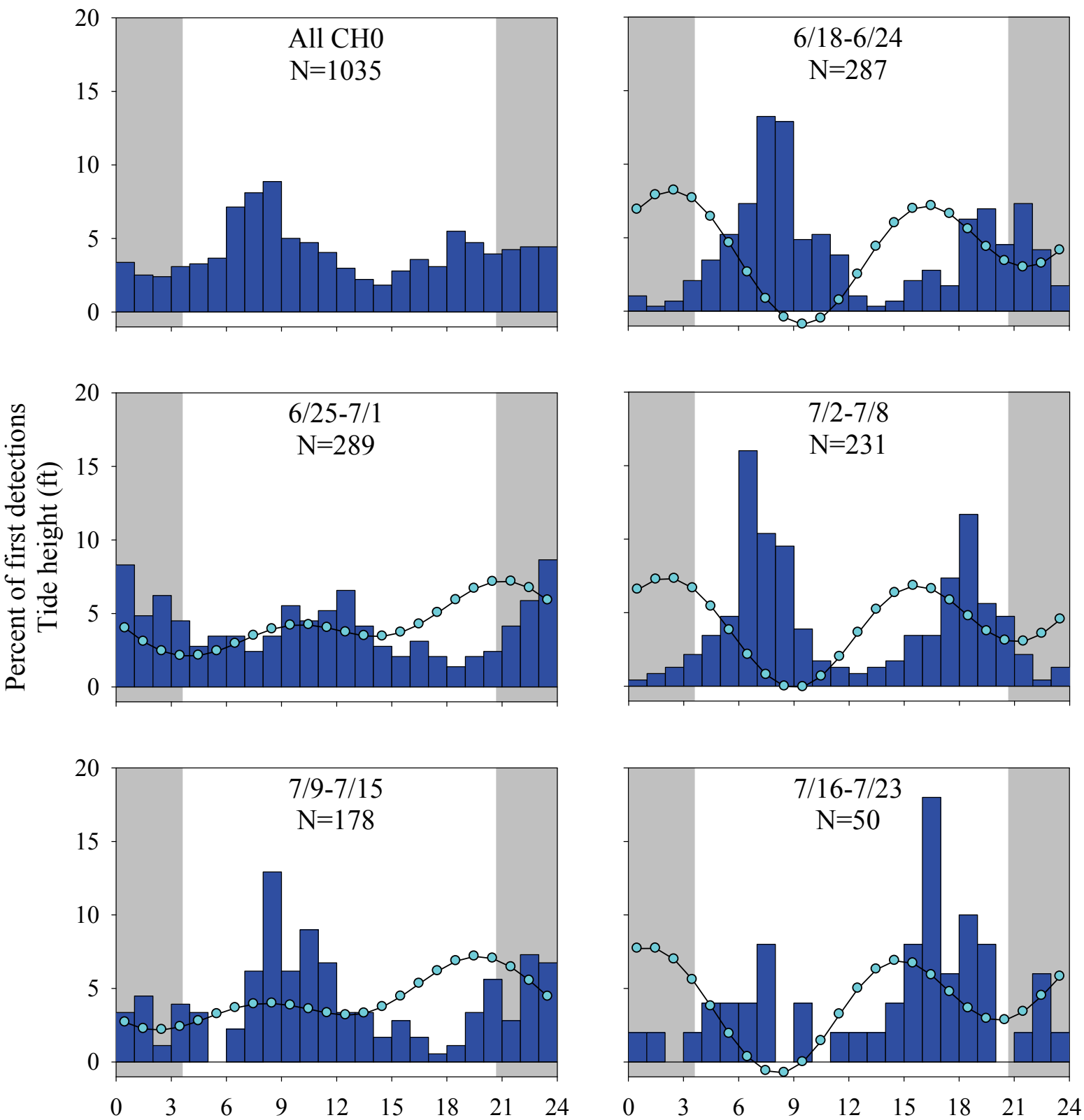

Hour

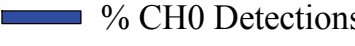

-

Figure 3.52. Hourly distribution at the Astoria Bridge array (CR022.0) for all subyearling Chinook salmon (top left panel). The rest of the panels show hourly distributions of 5 groups of subyearling Chinook salmon (based on virtual release week at Bonneville Dam) and average hourly tide stage in feet at array CR022.0 on the Columbia River. The average tide stage was calculated using the estimated tide at Astoria (Port Docks) for each hour during the days in which the middle $80 \%$ of the fish from each virtual release were first detected at array CR022.0. 


\section{CR008.3}
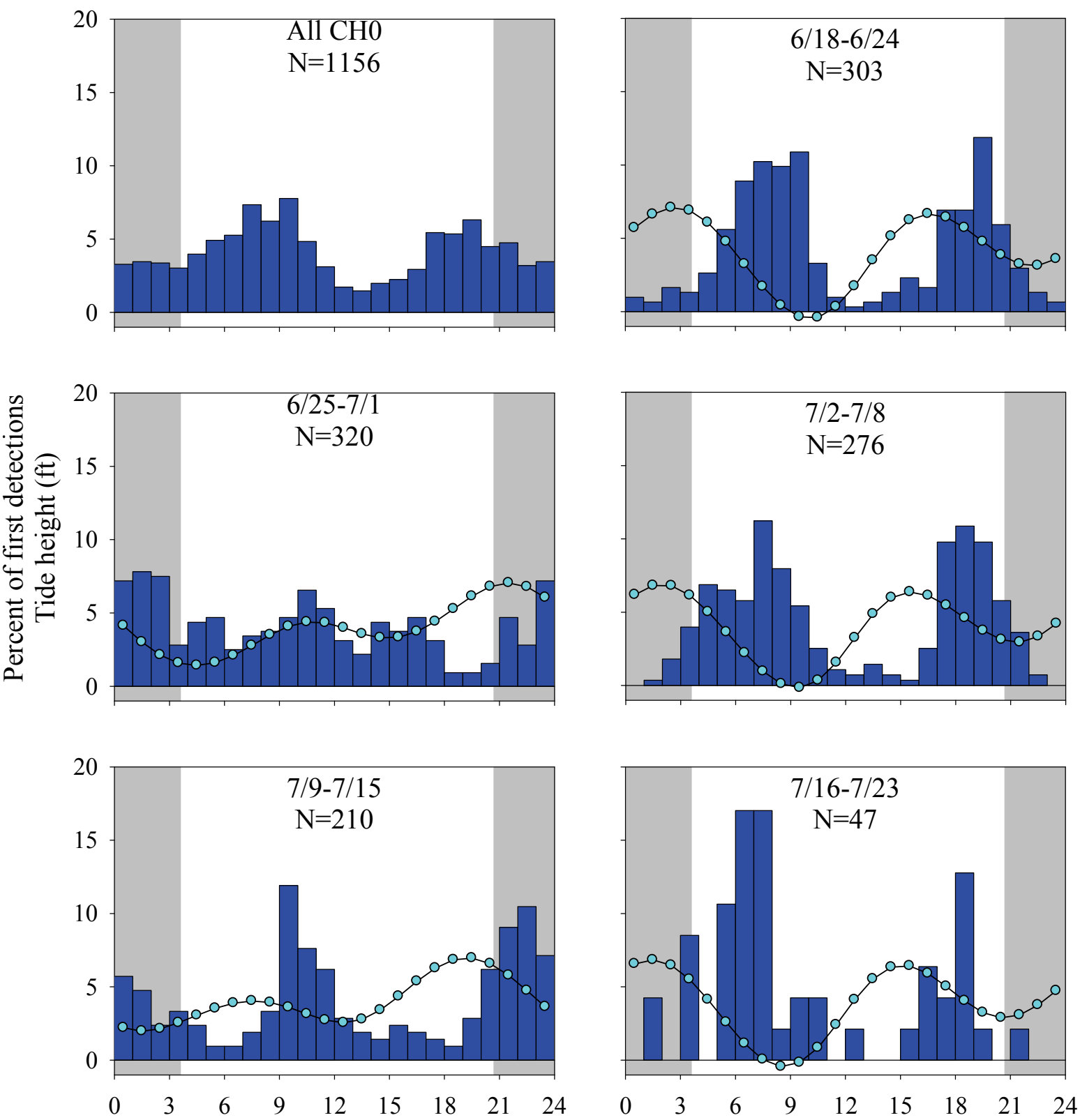

Hour

$\% \mathrm{CH} 0$ Detections

-

Figure 3.53. Hourly distribution at the East Sand Island array (CR008.3) for all subyearling Chinook salmon (top left panel). The rest of the panels show hourly distributions of 5 groups of subyearling Chinook salmon (based on virtual release week at Bonneville Dam) and average hourly tide stage in feet at array CR008.3 on the Columbia River. The average tide stage was calculated using the estimated tide at Chinook for each hour during the days in which the middle $80 \%$ of the fish from each virtual release were first detected at array CR008.3. 


\section{CR002.8}
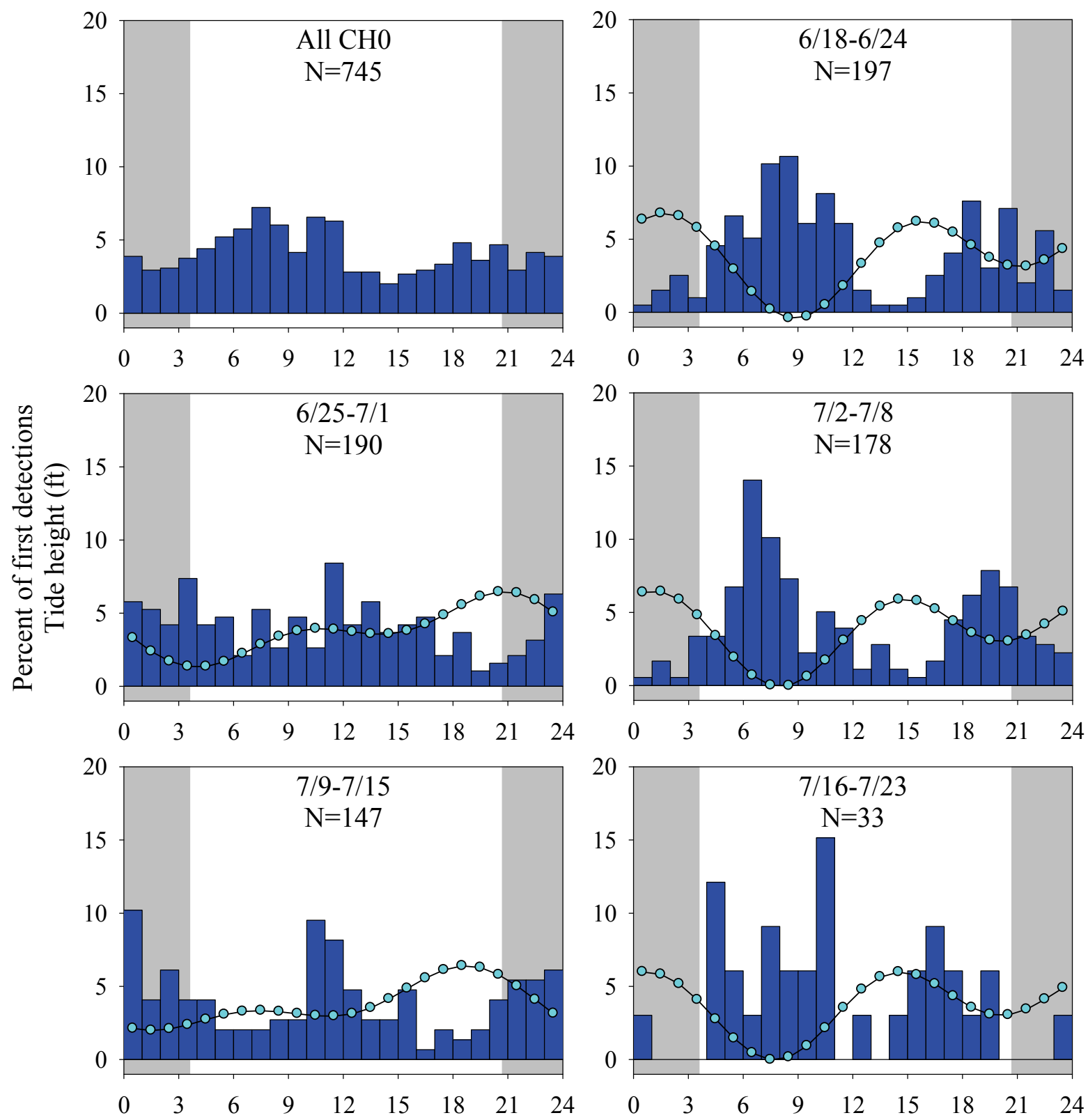

Hour

$\% \mathrm{CH} 0$ Detections

$\multimap$ Tide Height (ft)

Figure 3.54. Hourly distribution at the Columbia River Bar array (CR002.8) for all subyearling Chinook salmon (top left panel). The rest of the panels show hourly distributions of 5 groups of subyearling Chinook salmon (based on virtual release week at Bonneville Dam) and average hourly tide stage in feet at array CR002.8 on the Columbia River. The average tide stage was calculated using estimated tide at the North Jetty for each hour during the days in which the middle $80 \%$ of the fish from each virtual release were first detected at array CR002.8. 

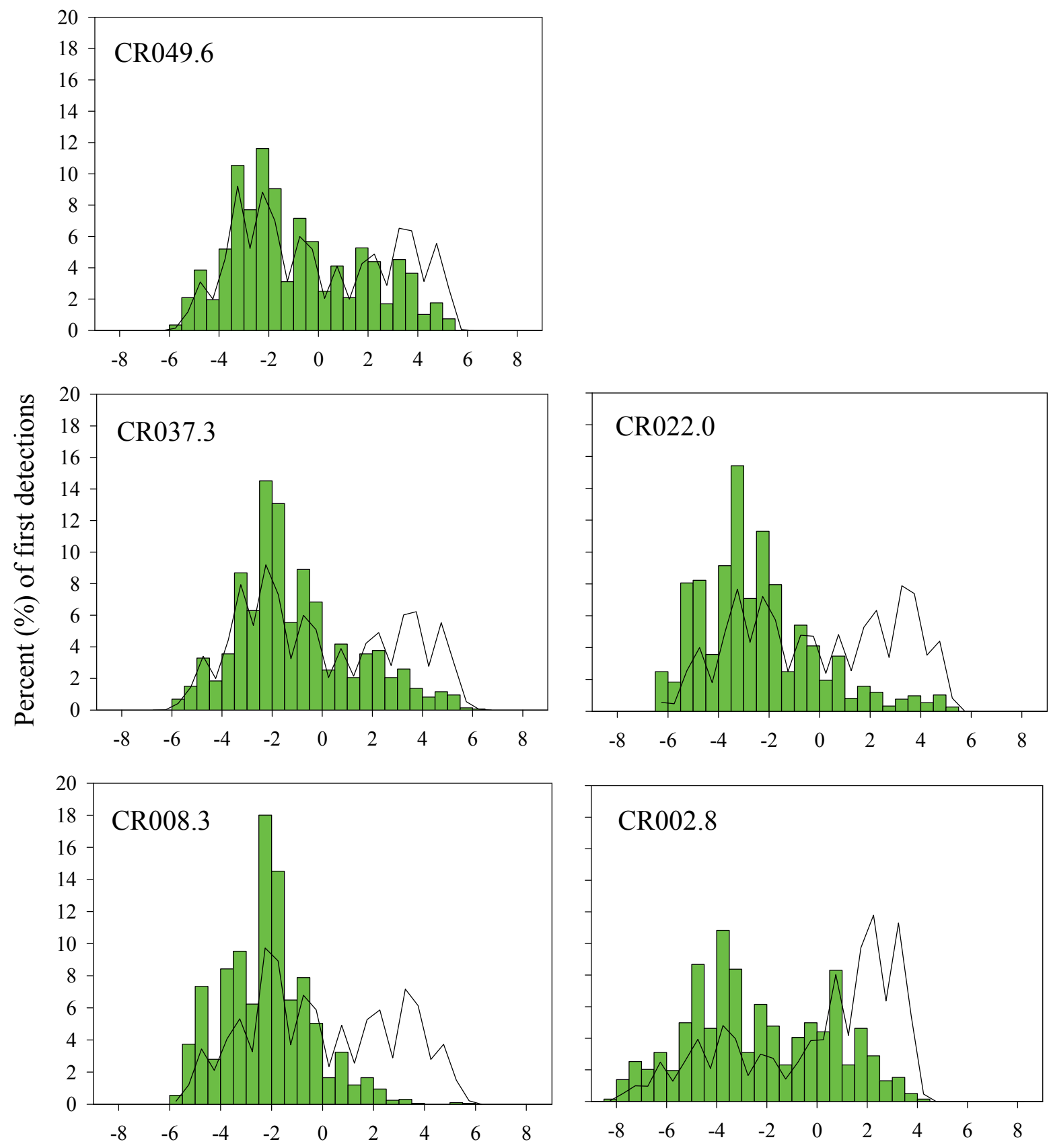

Tide change $(\mathrm{cm} / 5-\mathrm{min})$

Figure 3.55. Percentage of first detections of yearling Chinook salmon on arrays at Three Tree Point (CR049.6), Harrington Point (CR037.3), the Astoria Bridge (CR022.0), East Sand Island (CR008.3), and the Columbia River Bar (CR002.8) versus change in tide elevation. The percent occurrence of each tide change is displayed as the solid line. 

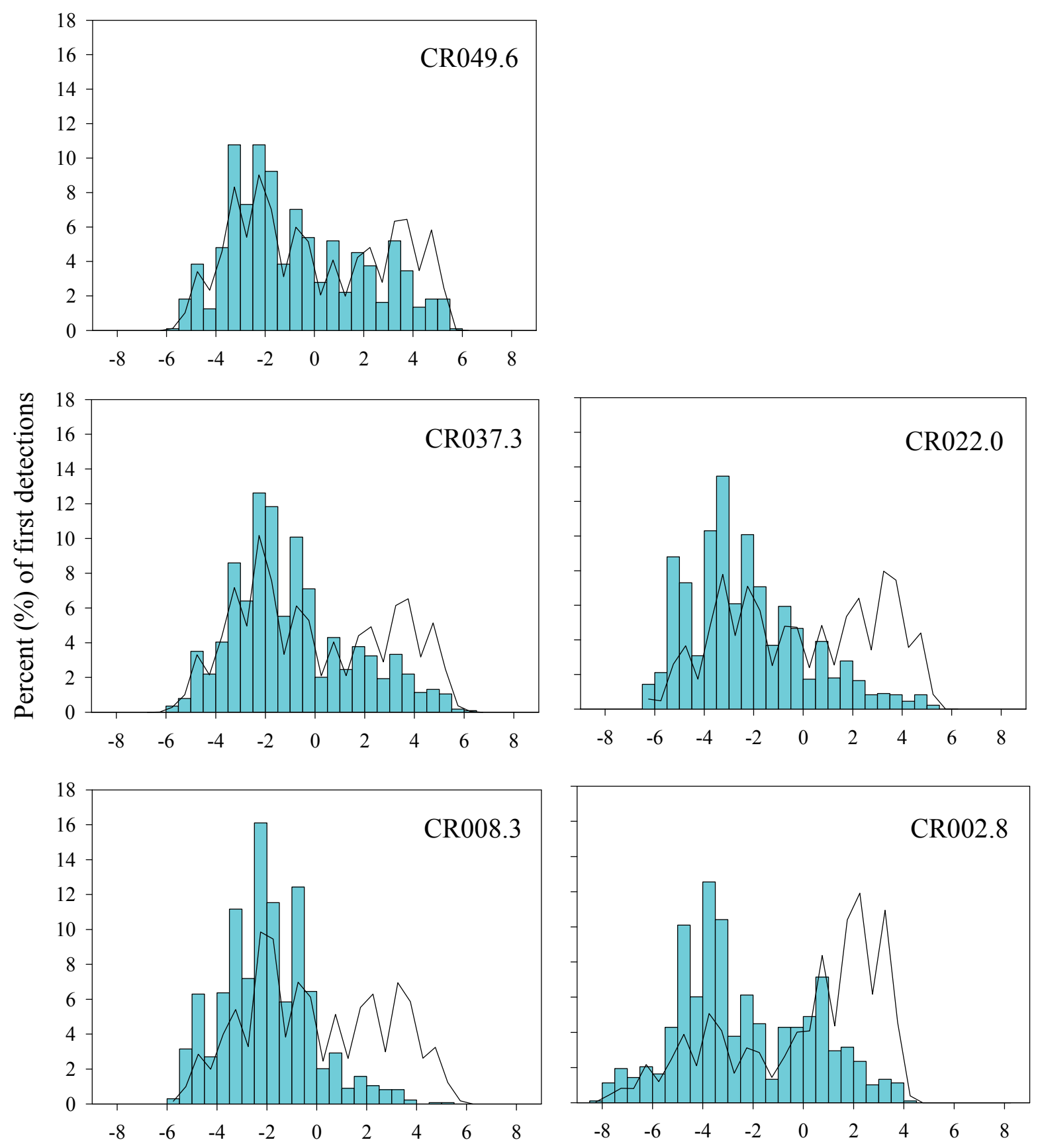

Tide change $(\mathrm{cm} / 5-\mathrm{min})$

Figure 3.56. Percentage of first detections of steelhead on arrays at Three Tree Point (CR049.6), Harrington Point (CR037.3), the Astoria Bridge (CR022.0), East Sand Island (CR008.3), and the Columbia River Bar (CR002.8) versus change in tide elevation. The percent occurrence of each tide change is displayed as the solid line. 

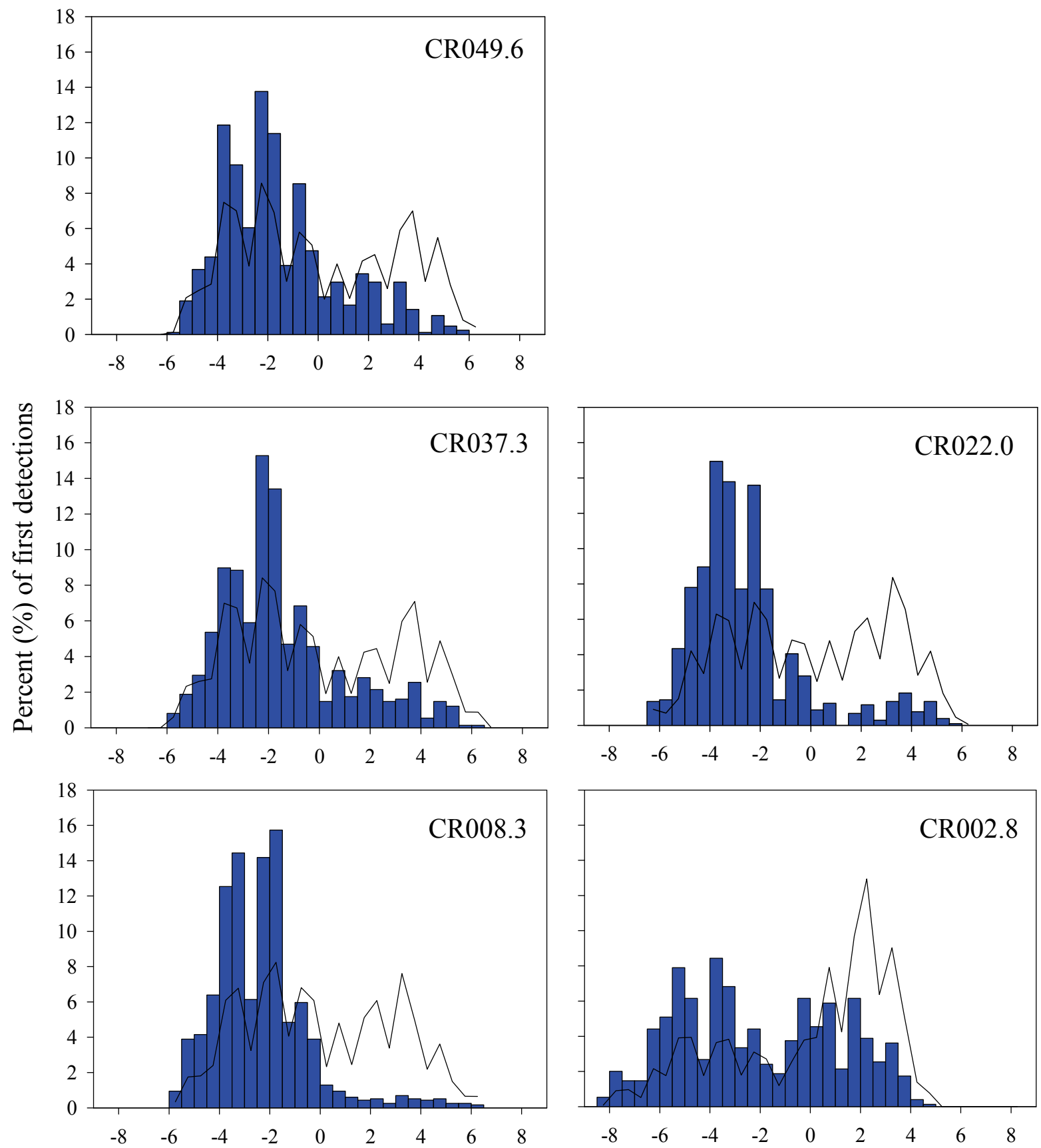

Tide change $(\mathrm{cm} / 5-\mathrm{min})$

Figure 3.57. Percentage of first detections of subyearling Chinook salmon on arrays at Three Tree Point (CR049.6), Harrington Point (CR037.3), the Astoria Bridge (CR022.0), East Sand Island (CR008.3), and the Columbia River Bar (CR002.8) versus change in tide elevation. The percent occurrence of each tide change is displayed as the solid line. 


\subsubsection{Avian Predation}

A total of 766 JSATS-tagged fish released at Roosevelt, Washington, in 2009 were detected on Caspian tern or double-crested cormorant colonies on East Sand Island. Of those, 164 were yearling Chinook salmon, which was $5.5 \%$ of all JSATS-tagged yearling Chinook salmon detected in the Bonneville Dam forebay at CR236.0 (Table 3.5). The greatest percentage of yearling Chinook salmon detected on the bird colonies were from the middle three virtual release groups. The first virtual release group of yearling Chinook salmon, which passed CR236.0 from April 30 to May 6 had the lowest percentage of tags detected on the bird colonies. The majority $(66 \%)$ of PIT tags for JSATS + PIT-tagged fish detected on the bird colonies had been implanted in steelhead smolts. A total of 504 PIT tags from JSATS-tagged steelhead were detected on the colonies, which was almost $17 \%$ of those detected at CR236.0 (Table 3.5). The trend by virtual release group for steelhead followed that of yearling Chinook salmon, with the middle three groups experiencing the highest predation rate, and the first group the lowest. Ninety-five (95) PIT tags from JSATS+PIT-tagged subyearling Chinook salmon were detected on the bird colonies, which was about 5\% of all fish detected at CR236.0 (Table 3.6). The highest predation rate was observed for the first virtual release group, which passed CR236.0 during the week of June 18. The avian predation rate on subyearling Chinook salmon declined thereafter until the final virtual release week (June 16).

Tags from yearling and subyearling Chinook salmon that were detected on the island were detected nearly equally between the two colonies, with 53\% and 54\% of the yearling Chinook salmon and subyearling Chinook salmon tags, respectively, detected on the tern colony. In contrast, steelhead appeared to be more vulnerable to predation from Caspian terns; $68 \%$ of the steelhead tags detected on the island were detected on the tern colony.

Table 3.5. Number and percentage of JSATS+PIT-tagged yearling (CH1) and subyearling $(\mathrm{CH} 0)$ Chinook salmon and steelhead (STH) from each virtual release group whose PIT tags were detected on the East Sand Island bird colonies.

\begin{tabular}{|c|c|c|c|c|c|c|c|c|c|c|c|}
\hline \multicolumn{4}{|c|}{$\mathrm{CH} 1$} & \multicolumn{4}{|c|}{ STH } & \multicolumn{4}{|c|}{$\mathrm{CH} 0$} \\
\hline $\begin{array}{c}\text { CR236.0 } \\
\text { week }\end{array}$ & $\begin{array}{c}\text { CR236.0 } \\
\mathrm{N}\end{array}$ & $\begin{array}{c}\text { Colonies } \\
\mathrm{N}\end{array}$ & $\%$ & $\begin{array}{c}\text { CR236.0 } \\
\text { week }\end{array}$ & $\begin{array}{c}\text { CR236.0 } \\
\mathrm{N}\end{array}$ & $\begin{array}{c}\text { Colonies } \\
\mathrm{N}\end{array}$ & $\%$ & $\begin{array}{c}\text { CR236.0 } \\
\text { week }\end{array}$ & $\begin{array}{c}\text { CR236.0 } \\
\mathrm{N}\end{array}$ & $\begin{array}{c}\text { Colonies } \\
\mathrm{N}\end{array}$ & $\%$ \\
\hline Apr 30 & 469 & 20 & 4.3 & Apr 29 & 468 & 57 & 12.2 & Jun 18 & 467 & 31 & 6.6 \\
\hline May 7 & 822 & 47 & 5.7 & May 6 & 792 & 137 & 17.3 & Jun 25 & 502 & 29 & 5.8 \\
\hline May 14 & 760 & 44 & 5.8 & May 13 & 723 & 128 & 17.7 & Jul 2 & 444 & 20 & 4.5 \\
\hline May 21 & 756 & 44 & 5.8 & May 20 & 745 & 138 & 18.5 & Jul 9 & 438 & 8 & 1.8 \\
\hline May 28 & 169 & 9 & 5.3 & May 27 & 274 & 44 & 16.1 & Jul 16 & 148 & 7 & 4.7 \\
\hline Total & 2976 & 164 & 5.5 & Total & 3002 & 504 & 16.8 & Total & 1999 & 95 & 4.8 \\
\hline
\end{tabular}

Yearling Chinook salmon and steelhead whose PIT tags were detected on the bird colonies were last detected in the river as far upstream as the forebay of Bonneville Dam (CR236.0; Table 3.6). Subyearling Chinook salmon detected on the bird colonies were last detected in the river as far upstream as the Lady Island array (CR192.0; Table 3.6). The greatest percentage of yearling Chinook salmon and steelhead detected on the bird colonies were last detected in the river at the Oak Point array (CR086.2). However, the detection probability of the next two downstream arrays (Three Tree Point [CR049.6] and Harrington Point [CR037.3]; Table 3.6) were relatively low. Therefore, fish last detected at CR086.2 may have 
passed these arrays without being detected and could have been consumed by avian predators farther downstream than indicated by these results. The highest percentage of subyearling Chinook salmon detected on the bird colonies were last detected in the river at the East Sand Island array (CR008.3).

Table 3.6. Numbers and percentages of fish whose tags were detected on the East Sand Island bird colonies by location of last in-river detection and the detection probability of each array.

\begin{tabular}{|c|c|c|c|c|c|c|c|c|c|}
\hline \multirow[b]{3}{*}{ Array } & \multicolumn{6}{|c|}{ Last detected } & \multicolumn{3}{|c|}{ Array detection probability } \\
\hline & \multicolumn{2}{|c|}{$\mathrm{CH} 1$} & \multicolumn{2}{|c|}{ STH } & \multicolumn{2}{|c|}{$\mathrm{CH} 0$} & $\mathrm{CH} 1$ & STH & $\mathrm{CHO}$ \\
\hline & $\mathrm{N}$ & $\%$ & $\mathrm{~N}$ & $\%$ & $\mathrm{~N}$ & $\%$ & & & \\
\hline CR236.0 & 1 & 0.6 & 1 & 0.2 & 0 & 0 & N/A & N/A & $\mathrm{N} / \mathrm{A}$ \\
\hline CR192.0 & 0 & 0 & 2 & 0.4 & 2 & 2.1 & 0.92 & 0.98 & 0.90 \\
\hline CR113.0 & 0 & 0 & 10 & 2.0 & 1 & 1.1 & 0.92 & 0.94 & 0.93 \\
\hline CR086.2 & 43 & 26.2 & 180 & 35.5 & 11 & 11.6 & 0.94 & 0.87 & 0.91 \\
\hline CR049.6 & 36 & 22.0 & 64 & 12.6 & 7 & 7.4 & 0.54 & 0.57 & 0.42 \\
\hline CR037.3 & 20 & 12.2 & 73 & 14.4 & 10 & 10.5 & 0.56 & 0.52 & 0.50 \\
\hline CR034.0 & 0 & 0 & 2 & 0.4 & 4 & 4.2 & N/A & N/A & N/A \\
\hline CR029.3 & 2 & 1.2 & 6 & 1.2 & 2 & 2.1 & N/A & N/A & $\mathrm{N} / \mathrm{A}$ \\
\hline CR022.0 & 29 & 17.7 & 109 & 21.5 & 12 & 12.6 & 0.74 & 0.76 & 0.68 \\
\hline CR008.3 & 23 & 14.0 & 43 & 8.5 & 34 & 35.8 & 0.86 & 0.91 & 0.84 \\
\hline CR002.8 & 10 & 6.1 & 17 & 3.4 & 12 & 12.6 & N/A & N/A & N/A \\
\hline Total & 164 & & 507 & & 95 & & & & \\
\hline
\end{tabular}

\subsubsection{Cross-Channel Distribution}

The cross-channel distribution of detections at the Astoria Bridge (CR022.0), East Sand Island (CR008.3), and Columbia River Bar (CR002.8) arrays for fish whose tags were detected on the bird colonies was generally similar to that of the total population of fish detected on those arrays (Figures $3.58,3.59$, and 3.60). 

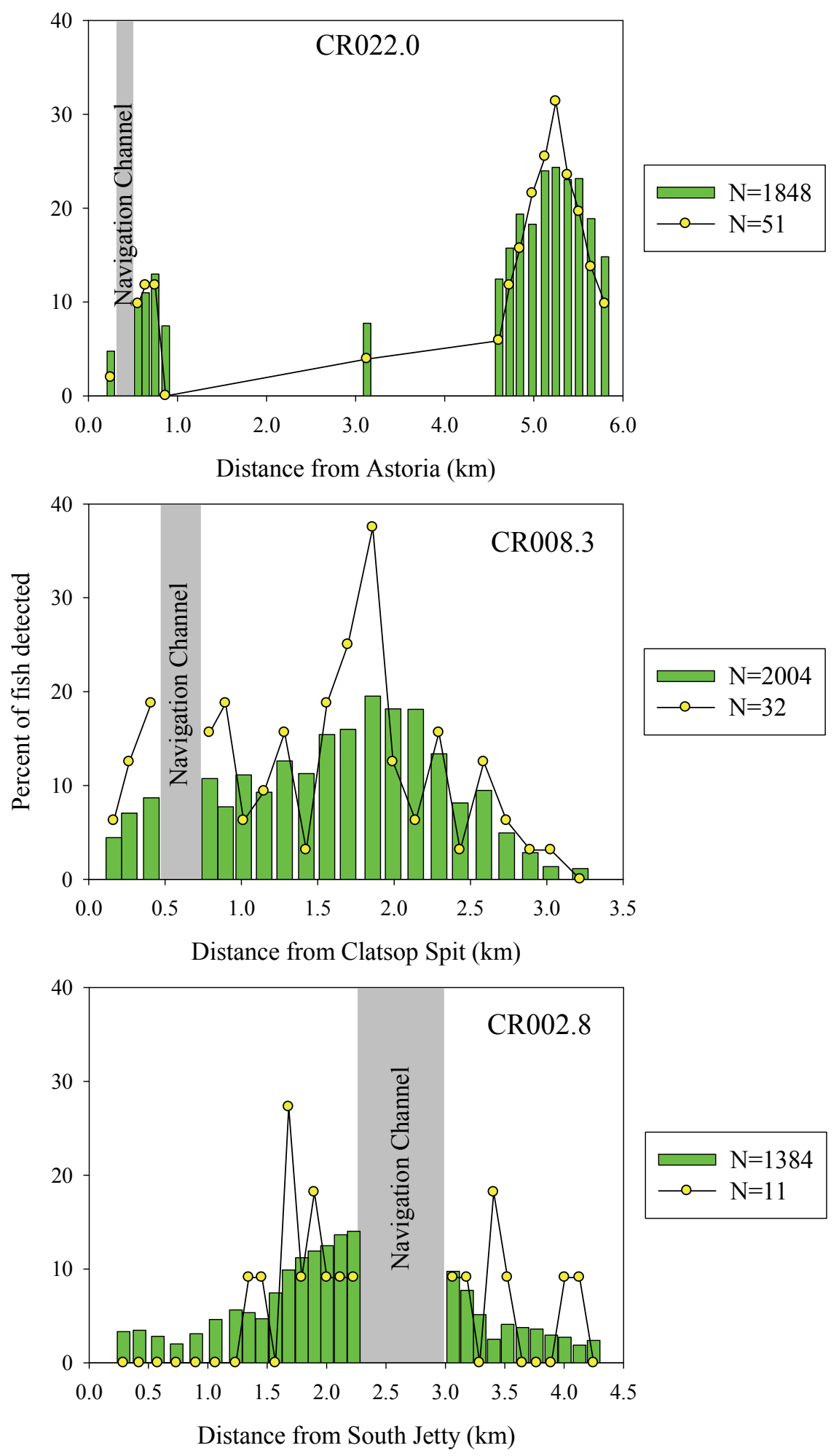

Figure 3.58. Cross-channel distribution of all yearling Chinook salmon (bars) and those whose tags were recovered on the East Sand Island bird colonies (line) on arrays at the Astoria Bridge (CR022.0), East Sand Island (CR008.3), and the Columbia River Bar (CR002.8). 

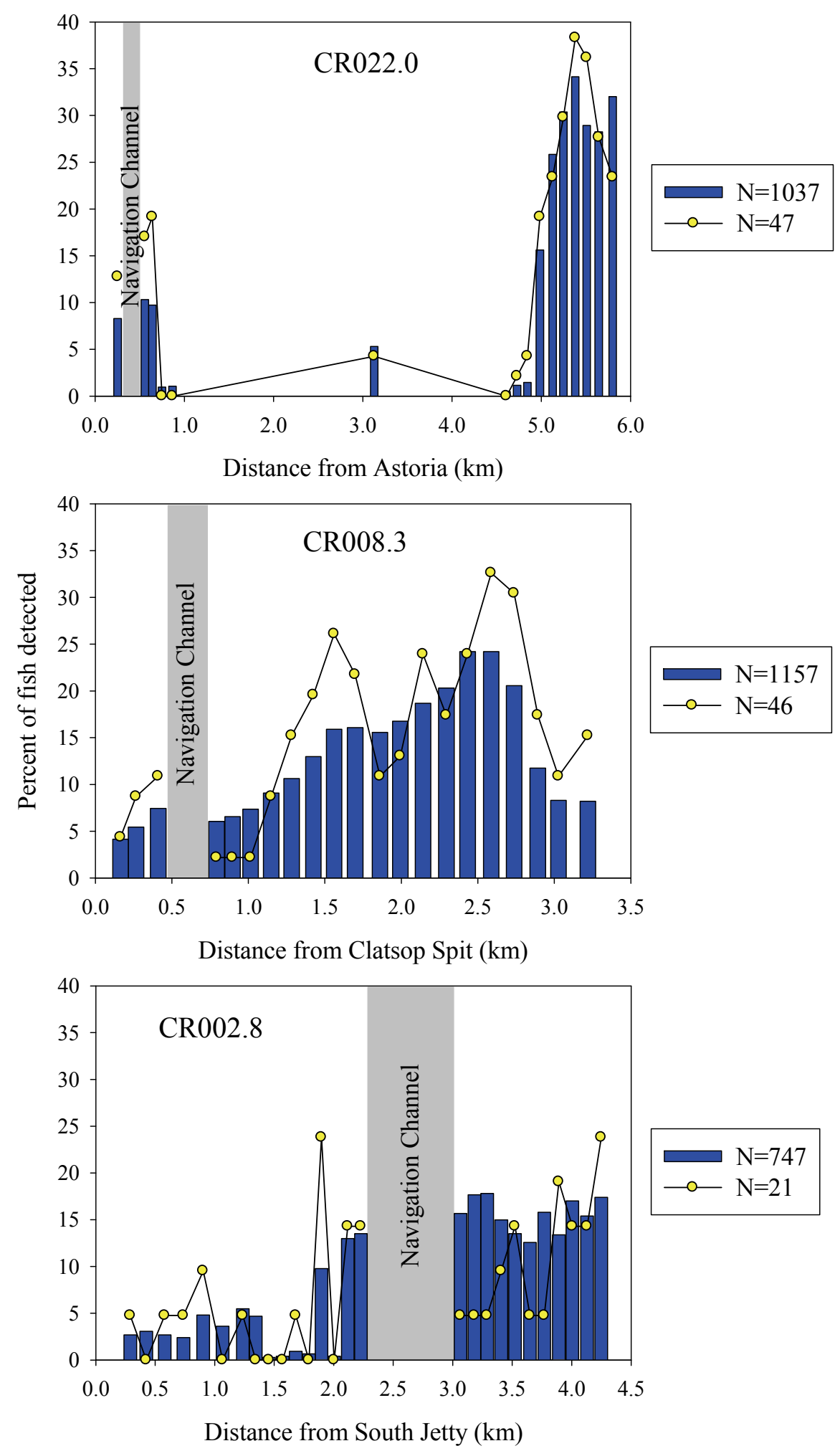

Figure 3.59. Cross-channel distribution of all subyearling Chinook salmon (bars) and those whose tags were recovered on the East Sand Island bird colonies (line) on arrays at the Astoria Bridge (CR022.0), East Sand Island (CR008.3), and the Columbia River Bar (CR002.8). 

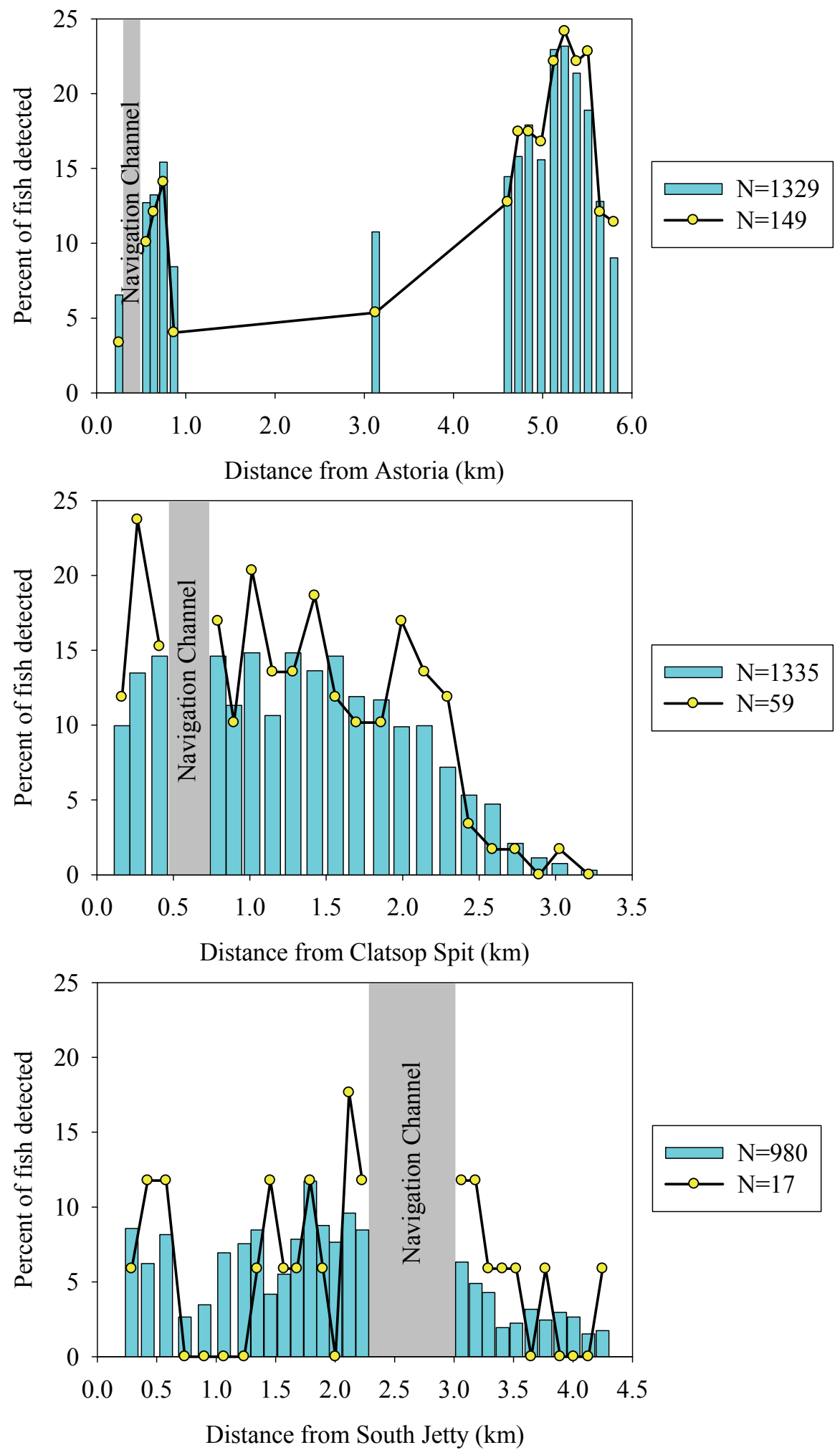

Figure 3.60. Cross-channel distribution of all steelhead (bars) and those whose tags were recovered on the East Sand Island bird colonies (line) on arrays at the Astoria Bridge (CR022.0), East Sand Island (CR008.3), and the Columbia River Bar (CR002.8). 


\subsection{Discussion}

The primary objective of this study was to estimate the survival of yearling and subyearling Chinook salmon and steelhead through multiple reaches of the Columbia River between Bonneville Dam and the Pacific Ocean. For our results, obtained from fish implanted with acoustic transmitters, to be applicable to the untagged population, the tagged sample had to be representative of the general population. Because the size of fish implanted with acoustic transmitters and the timing of fish collection and receiver deployment closely matched that of the run-at-large, we determined the tagged sample to be representative of the general population. Additionally, the battery life of implanted transmitters was of sufficient duration to allow fish to migrate through the entire study area with minimal tag failure effects.

In general, detection probabilities of receiver arrays deployed across the entire channel were high, providing precise estimates of survival. However, the detection probability of the Oak Point (CR086.2) and Lady Island (CR192.0) arrays displayed a negative relationship with river discharge. At CR086.2, the relationship was not consistent over the range of observed discharges indicating that seasonal effects or differences in fish behavior may have affected detection probability of this array. Detection probability of the partial array at Three Tree Point (CR049.6) increased with increasing discharge. Because receivers in this array were only deployed across the primary navigation channel, it is possible that a greater proportion of tagged fish migrated in the main navigation channel during high flows and were detected by the array than during periods of low flows when more fish may have passed the array through secondary channels where they would go undetected.

Detection probabilities of partial arrays at Three Tree Point (CR049.6) and Harrington Point (CR037.3) were relatively low. Because receivers were only deployed across the primary channel at these locations, fish that passed these arrays through secondary channels went undetected. This resulted in failure of Burnham Test 2 for array CR037.3, indicating that fish were more likely to be detected at CR037.3 if they were previously detected at CR049.6. Previous research indicated that 15 to $19 \%$ of steelhead and $6 \%$ of yearling Chinook salmon, and likely higher percentages of subyearling Chinook salmon, migrate outside the primary channel at rkm 37 (Schreck et al. 2005). Because virtual releases are formed at the upstream array for estimates of reach survival, only fish migrating in the main channel would be included in survival estimates from CR049.6 to CR037.3 and from CR037.3 to the Astoria Bridge array (CR022.0). Therefore, survival estimates were not calculated for these reaches. Although fish may have migrated through secondary channels and avoided detection at CR049.6, it did not affect their downstream detection history at CR022.0. Additionally, a relatively low proportion of fish migrate outside the main channel at $\mathrm{rkm} 49.6$ (Schreck et al. 2005). Therefore, reach survival estimates were calculated from CR049.6 to CR022.0.

This report includes some of the first information regarding the effects of passage route history at John Day and Bonneville dams on delayed mortality of fish in the Columbia River estuary. However, these results should be used with caution. Because it was not the primary objective of this study to assess latent mortality by passage history, insufficient sample sizes existed for many groups of fish sharing the same passage history, resulting in survival estimates with relatively large error bounds. To accurately assess the effects of passage history on latent mortality of fish in the estuary, a power analysis should be conducted to determine the sample size required to observe a meaningful effect. 
Annual estimated pooled survival of yearling Chinook salmon smolts from Bonneville Dam to the mouth of the Columbia River ( $\mathrm{rkm} 8.3$ ) has ranged from 0.665 to 0.799 between 2005 and 2009. By adding new JSATS arrays between Bonneville Dam and East Sand Island (rkm 8.3) in 2007 and 2008, we determined that the majority of the loss of yearling Chinook salmon occurred between Three Tree Point (rkm 50) and rkm 8 (McComas et al. in prep; Table 4.1, this report). Based on information from our efforts in 2007 and 2008, we increased the number of autonomous receivers in the lower $50 \mathrm{~km}$ of the estuary in 2009 to more clearly define where the greatest losses were occurring. Survival of yearling Chinook salmon from virtual release in the forebay of Bonneville Dam was high in the lower Columbia River and estuary (above rkm 50) in 2009 before declining sharply downstream of rkm 50. Survival per kilometer estimates revealed that the highest mortality rate for yearling Chinook salmon smolts occurred in the farthest downstream reach, between the Astoria Bridge ( $\mathrm{rkm} \mathrm{22)}$ and East Sand Island (rkm 8.3).

Estimated survival of subyearling Chinook salmon from Bonneville Dam to the mouth of the Columbia River (rkm 8.3) has ranged from 0.620 to 0.836 between 2005 and 2009 (Table 4.2). By adding new JSATS arrays between Bonneville Dam and East Sand Island (rkm 8.3) in 2007 and 2008, we determined that the majority of the loss of yearling Chinook salmon occurred between rkm 50 and rkm 8 during the early portion of their emigration season in 2007 and 2008 (before 10 July; McComas et al. in prep; Table 4.2, this report). Survival of yearling Chinook salmon from virtual release in the forebay of Bonneville Dam in 2009 was relatively high in the lower Columbia River and estuary (upstream of Oak Point [rkm 86]) but showed a higher rate of loss through the lower $86 \mathrm{~km}$, with the highest rate of loss between the Astoria Bridge (rkm 22) and East Sand Island (rkm 8.3). It remains to be determined whether a portion of the subyearling Chinook salmon that fail to emigrate from the Columbia River downstream of Bonneville in the same year they pass the dam elect to remain in the lower river or estuary to extend their rearing period prior to emigrating to sea (Connor et al. 2002, 2005, Buchanan et al. 2009).

This study provided the first estimates of steelhead survival from Bonneville Dam to mouth of the Columbia River using the JSATS. Survival of steelhead smolts from virtual release in the forebay of Bonneville Dam was much lower than that of either Chinook salmon stock but was generally high in the lower Columbia River down to about Oak Point (rkm 86) before declining very sharply between rkm 86 and East Sand Island (rkm 8). Reach survival estimates also indicated that survival of steelhead was lowest downstream of rkm 86. Survival per kilometer estimates revealed that the highest mortality rate occurs in the farthest downstream reach, between the Astoria Bridge (rkm 22) and East Sand Island (rkm 8.3). It is possible that steelhead behavior influences mortality in the Columbia River estuary with their tendency to migrate closer to the surface, which may relate to why PIT tags from the steelhead in our study were more likely to be recovered on the Caspian tern colony than the double-crested cormorant colony.

In 2009, acoustic-tagged yearling Chinook salmon had a median travel time of $3.1 \mathrm{~d}$ from the forebay of Bonneville Dam to the mouth of the Columbia River (rkm 8.3), which compares closely to previous years. In 2006, 2007, and 2008 acoustic-tagged yearling Chinook salmon had median travel times of 3.3, 3.1 and $3.3 \mathrm{~d}$, respectively, from release in the tailrace of Bonneville Dam to the East Sand Island array (CR008.3; McComas et al. 2008, in prep). Also similar to the trend observed in 2006, 2007 and 2008, travel time, and variability in travel time decreased over the course of the season (McComas et al. 2008; in prep). In 2006, 2008, and 2009 decreases in travel time as the season progressed were associated with increasing discharge. However, in 2007, discharge remained relatively constant, even declining slightly, as spring progressed. Yet, later-migrating yearling Chinook salmon still migrated faster than earlier migrants, indicating physiological processes may affect travel time of emigrating yearling Chinook 


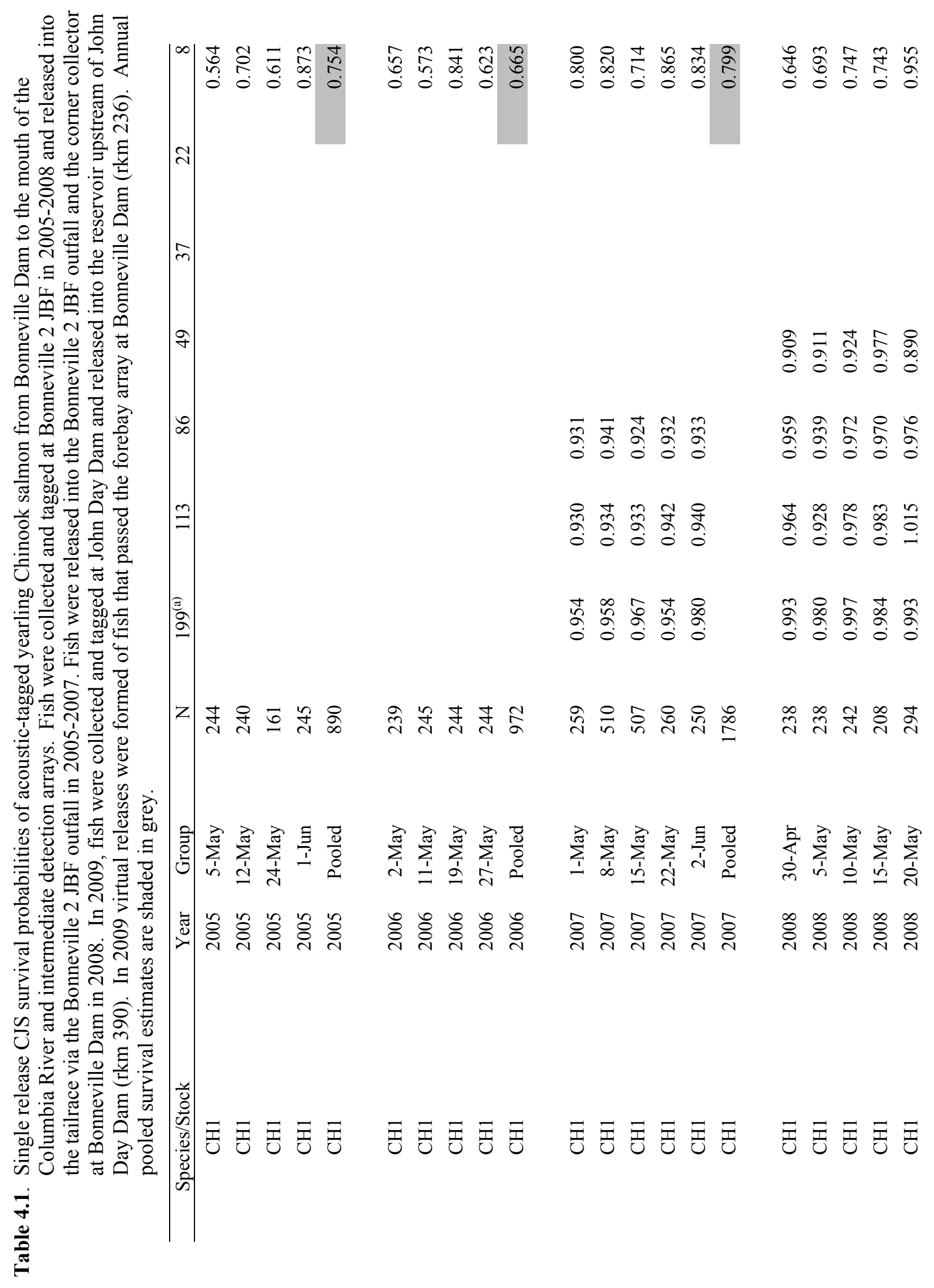




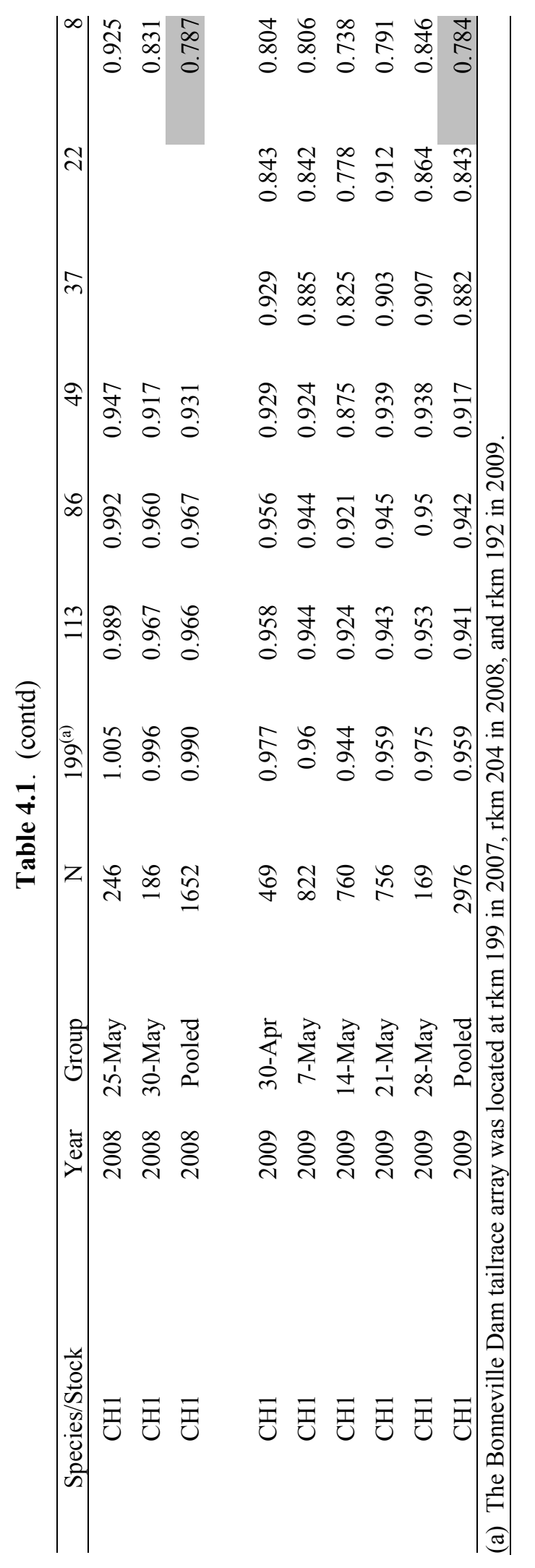




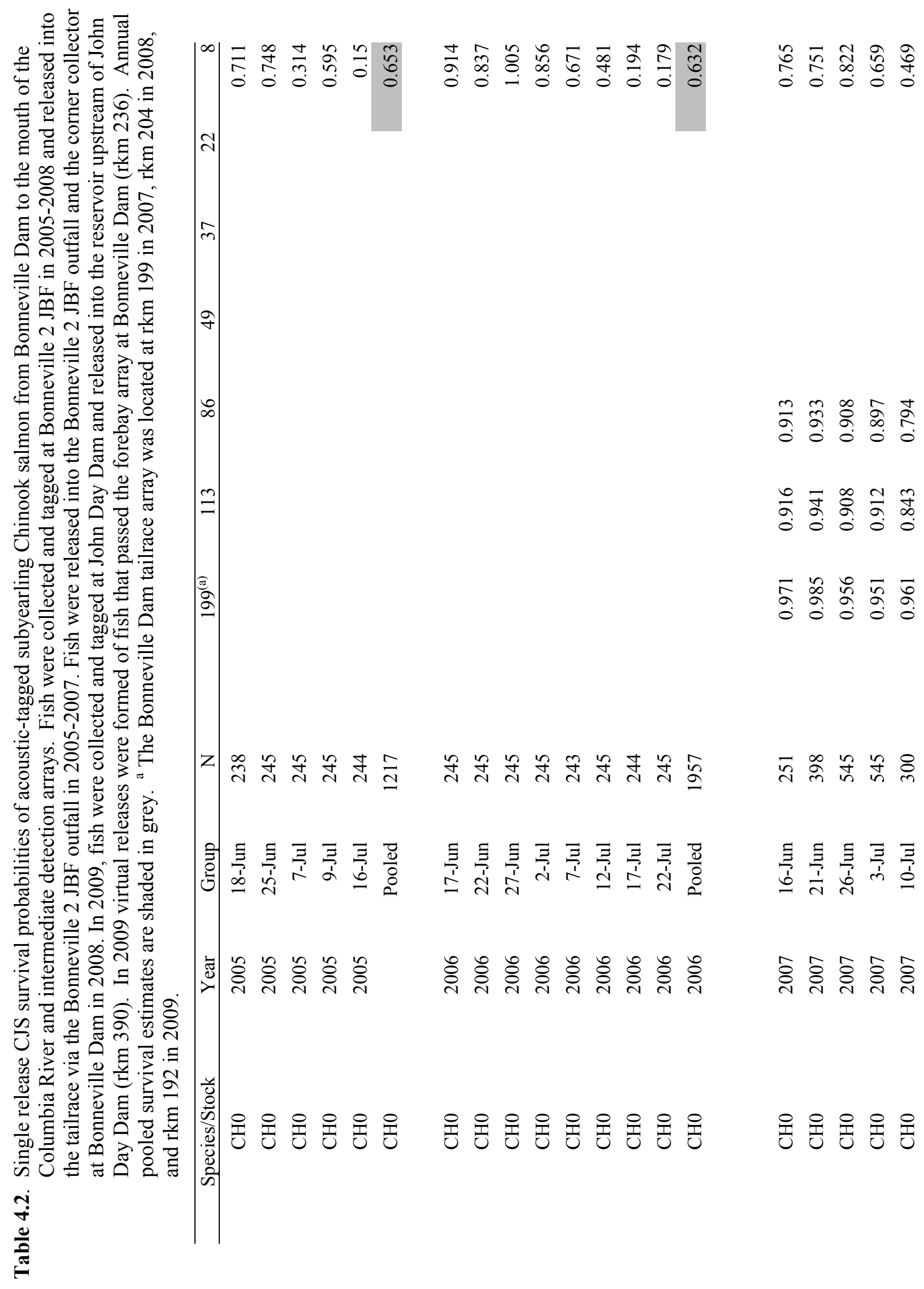




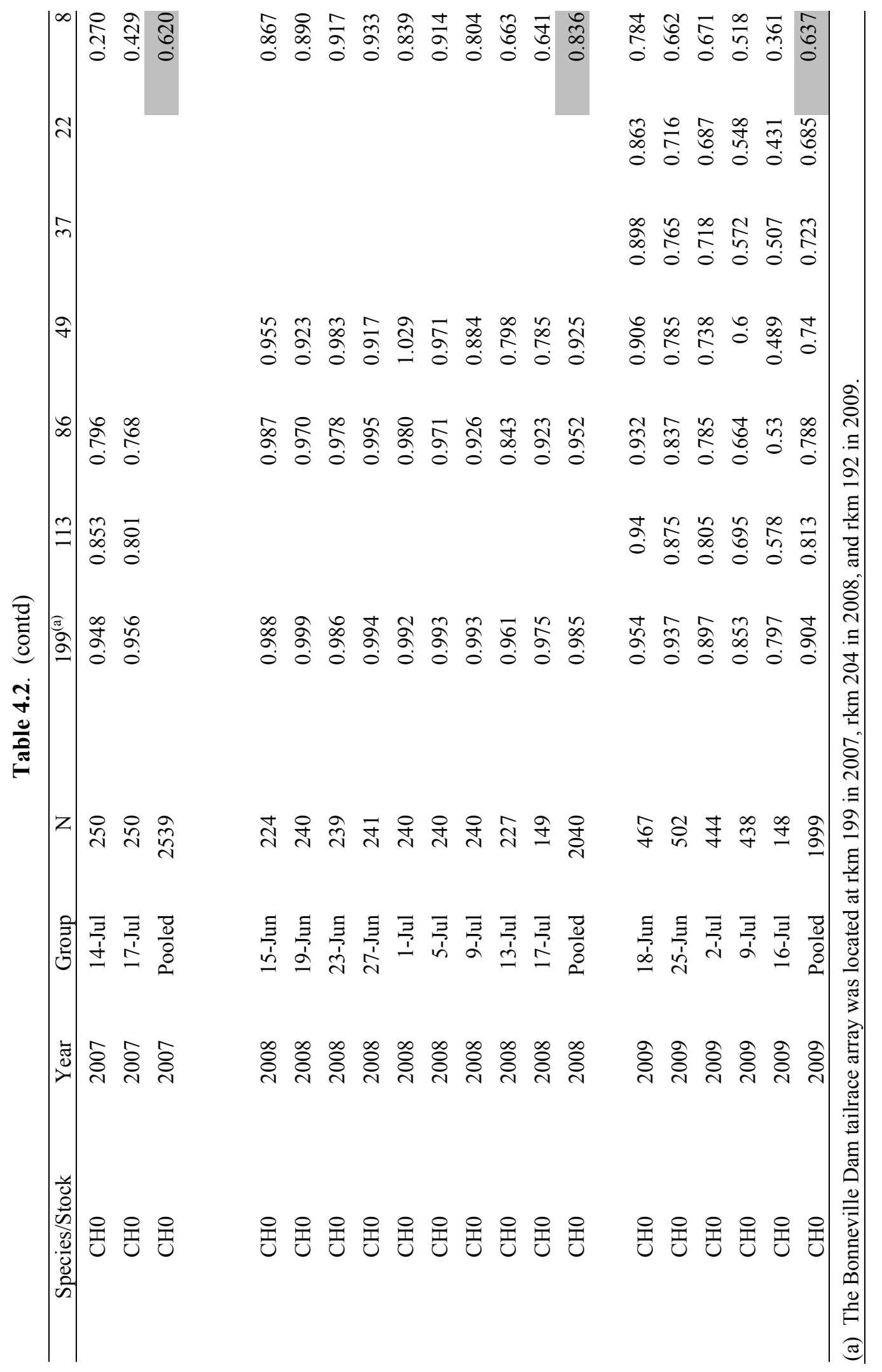


salmon more than discharge. Travel rate of yearling Chinook salmon followed the same trend observed in previous years; declining from about $75-100 \mathrm{~km} / \mathrm{d}$ in the upper estuary (upstream of Oak Point [rkm 86.2]) to about $40 \mathrm{~km} / \mathrm{d}$ in the lower estuary (between Three Tree Point [rkm 49.6] and the Astoria Bridge [rkm 22.0]), followed by an increase in median travel rate to about $100 \mathrm{~km} / \mathrm{d}$ and an increase in the variability about the median downstream of rkm 22.0.

Median travel time of steelhead from Bonneville Dam forebay to the mouth of the river (rkm 8.3) was $2.9 \mathrm{~d}$ in 2009. Trends in travel time and travel rate observed for steelhead in 2009 were similar to those observed for yearling Chinook salmon in 2006 through 2009; travel time and variability in travel time decreased over the course of the season and travel rate declined from the upper estuary to the lower estuary, followed by an increase in median travel rate and variability about the median downstream of the Astoria Bridge (rkm 22.0). Subyearling Chinook salmon had a median travel time of $3.9 \mathrm{~d}$ from the forebay of Bonneville Dam to the mouth of the Columbia River (rkm 8.3) in 2009, which was within the range observed in previous years. In 2006 through 2008, subyearling Chinook salmon released into the tailrace of Bonneville Dam had a median travel time of 3.5 to $4.3 \mathrm{~d}$ to $\mathrm{rkm}$ 8.3. Travel time generally increased over the course of the summer in 2009, which corresponded with decreasing river discharge. A similar trend was observed in 2008; lower travel times were associated with higher discharges. However, this trend was not evident in 2006 or 2007. Travel rate of subyearling Chinook salmon migrating from Bonneville Dam to the mouth of the river followed the same trend observed in previous years, which was similar to the trend observed for yearling Chinook salmon and steelhead; travel rate declined from the upper estuary to the lower estuary, followed by an increase in median travel rate and variability about the median downstream of the Astoria Bridge ( $\mathrm{rkm} 22.0)$. Results obtained from this study indicate that a greater proportion of subyearling Chinook salmon migrate through off-channel areas (outside the primary channel) than yearling Chinook salmon or steelhead. These results are consistent with those obtained in 2007 and 2008. In 2007, 20\% of acoustic-tagged subyearling Chinook salmon detected at Oak Point ( $\mathrm{rkm}$ 86.2) were detected in the secondary channels of Cathlamet Bay, compared to only $9 \%$ of yearling Chinook salmon. In 2008, 28\% of subyearling Chinook salmon detected at Oak Point were detected in the secondary channels of Cathlamet Bay or in Grays Bay, compared to $17 \%$ of yearling Chinook salmon and $13 \%$ of steelhead. In 2009, $26 \%$ of subyearling Chinook salmon detected at Harrington Point (rkm 37.3) were detected in Grays Bay, compared to 9\% of yearling Chinook salmon and $6 \%$ of steelhead.

Results obtained in 2006, 2007, 2008, and 2009 indicate that migration pathway has relatively little effect on travel times of acoustic-tagged smolts. In 2009, fish that migrated from Harrington Point (rkm 37.3) to the Astoria Bridge (rkm 22) through Grays had longer travel times than those that migrated through the main channel; however, differences were generally small (2-3 h). In 2007, median travel times of yearling and subyearling Chinook salmon that migrated from the secondary channels of Cathlamet Bay to the East Sand Island array ( $\mathrm{rkm} 8.3$ ) were nearly identical to those of fish that migrated from the main channel. In 2008, median travel times of subyearling Chinook salmon and steelhead that migrated from Oak Point (rkm 86.2) to rkm 8.3 were generally similar, regardless of whether they migrated through off-channel areas or in the main channel. However, yearling Chinook salmon that migrated through Grays Bay in 2008 displayed large variability in travel time, which was similar to results obtained in 2009. However, the difference in median travel times of yearling Chinook salmon that migrated through Grays Bay versus through the main channel in 2008 was much greater $(12 \mathrm{~h})$ than the difference observed in 2009. 
The use of different migration pathways by juvenile salmonids to navigate through the Columbia River estuary may affect their probability of survival. In 2008, acoustic-tagged steelhead that migrated from the main channel at Oak Point ( $\mathrm{rkm} \mathrm{86.2)} \mathrm{had} \mathrm{a} \mathrm{significantly} \mathrm{lower} \mathrm{probability} \mathrm{of} \mathrm{survival} \mathrm{to} \mathrm{the}$ East Sand Island array (CR008.3) than steelhead that migrated from the secondary channels of Cathlamet Bay. In 2009, acoustic-tagged steelhead and subyearling Chinook salmon that migrated from Harrington Point (CR037.3) through Grays Bay had lower survival to the Astoria Bridge (rkm 22) than fish that migrated from Harrington Point in the main channel. However, survival of subyearling Chinook salmon and steelhead was high between Grays Bay and the Astoria Bridge, indicating that much of the mortality incurred by subyearling Chinook salmon and steelhead that migrated from Harrington Point through Grays Bay occurred in a small area (3.3 km in length) directly north of Rice Island between the Harrington Point and Grays Bay receivers. This area is characterized by shallow water, which may increase the vulnerability of smolts passing through this area to avian predation. However, additional research is needed to determine whether the apparent mortality observed for subyearling Chinook salmon is actual mortality or whether a portion of these fish remain in these off-channel areas to extend their rearing period prior to emigrating to sea.

Although the majority of acoustic-tagged yearling and subyearling Chinook salmon and steelhead migrated from Harrington Point (rkm 37.3) in or near the main navigation channel, most of these fish were first detected at the Astoria Bridge ( $\mathrm{rkm} 22$ ) in the Washington shoreline channel. These data indicate that large numbers of smolts migrated past Rice Island (rkm 35.6) in the main channel, before traversing a large tidal flat (Taylor Sands) upstream of the Astoria Bridge. Although several small channels intersect Taylor Sands, connecting the main channel to the Washington shoreline channel (Figure X), smolts may be vulnerable to avian predators as they traverse the shallow tidal flat.

Movements of yearling and subyearling Chinook salmon and steelhead in the lower Columbia River estuary appear to be heavily influenced by tide. In each of the last four years (2006 - 2009) the majority of first detections of acoustic-tagged smolts at the East Sand Island array (CR008.3) occurred during ebb, or outgoing, tides. These data indicate that emigrating smolts are primarily moving passively near the mouth of the river. Schreck et al. (2005) observed a similar relationship between water velocity and behavior of smolts in the lower Columbia River estuary. During high water velocities, which occur during large tidal changes, the movement of smolts corresponded closely with the movements of simulated water particles (Schreck et al. 2005). This passive behavior may explain the large variability observed in the travel rate of acoustic-tagged smolts in the downstream-most reaches of the estuary. Some fish may be carried to the ocean on a single tide change, resulting in very high travel rates, whereas others may require multiple tide changes until a large enough ebb tide occurs to carry them all the way to the ocean. Fish that require multiple tide changes to migrate through the final reach of the estuary would appear to be moving slowly, having low travel rates, and may be more susceptible to avian predation due to their prolonged residence near the East Sand Island nesting colonies. This prolonged exposure to predation may help to explain the low survival rates observed for yearling and subyearling Chinook salmon and steelhead between the Astoria Bridge (rkm 22.0) and East Sand Island (rkm 8.3) arrays.

Subyearling Chinook salmon are influenced by tide to a greater extent than yearling Chinook salmon and steelhead. In 2009, detections of subyearling Chinook salmon were correlated with changes in tide as far upstream as Three Tree Point ( $\mathrm{rkm}$ 50), whereas this correlation was not as evident until farther downstream for yearling Chinook salmon and steelhead. Additionally, a greater proportion of subyearling Chinook salmon were detected on arrays downstream of rkm 50 during ebb tides than yearling Chinook salmon or steelhead in 2009. Because of their smaller size, subyearling Chinook 
salmon may be less likely to swim against the current than yearling Chinook salmon and steelhead, which are larger in size and stronger swimmers. Schreck et al. (2005) noted that steelhead appear to behave less passively to the tidal cycle.

Avian predation has been shown to account for a substantial amount of juvenile salmonid mortality in the Columbia River estuary (Collis et al. 2001; Roby et al. 2003; Ryan et al. 2003; Anderson et al. 2005, 2007). During the previous four years (2006 through 2009), 2.1\% to 5.5\% of yearling Chinook salmon implanted with acoustic transmitters to measure survival downstream of Bonneville Dam have been detected on the Caspian tern and double-crested cormorant nesting colonies on East Sand Island. The percentage (5.5\%) of acoustic-tagged yearling Chinook salmon detected on the colonies was higher than that observed during any of the previous three years. The percentage of acoustic-tagged subyearling Chinook salmon detected on the nesting colonies was $4.8 \%$ in 2009, which was near the upper end of the range observed in 2006, 2007, and 2008 (2.5\% to 4.9\%). Steelhead smolts appear to be particularly vulnerable to avian predation. In 2008, $15 \%$ of acoustic-tagged steelhead smolts detected by receiver arrays in the Columbia River near Oak Point ( $\mathrm{rkm}$ 86.2) were detected on the East Sand Island nesting colonies (Harnish et al. in prep). In 2009, 17\% of acoustic-tagged steelhead smolts detected at the Bonneville Dam forebay array (CR236.0) were detected on the East Sand Island nesting colonies. These percentages compare closely to previous studies that have found $9-16 \%$ of steelhead that pass Bonneville Dam are eaten by birds in the estuary (Collis et al. 2001; Roby et al. 2003; Ryan et al. 2003; Schreck et al. 2006). Based on last detections of acoustic-tagged fish, particularly steelhead, it appears that the foraging distance of Caspian terns may have been greater in 2009 than reported for radio-tagged terns by Anderson et al. (2007). Anderson et al. (2007) reported that average distance from the colony traveled by Caspian terns in the Columbia River estuary in 2000 and 2001 ranged from $13.9 \mathrm{~km}$ during the chick rearing period to $29.0 \mathrm{~km}$ following the fledging period. In 2009, the greatest proportion of PIT tags from steelhead detected in this study were last detected at rkm 86, approximately $78 \mathrm{~km}$ upstream of the Caspian tern nesting colony on East Sand Island.

Avian predators appear to be consuming steelhead smolts farther upstream than yearling and subyearling Chinook salmon. The greatest percentage of steelhead detected on the bird colonies were last detected at the Oak Point array (CR086.2), whereas the location of last detection for yearling Chinook salmon consumed by avian predators was more evenly distributed between $\mathrm{rkm} 86$ and the mouth of the river. The greatest percentage of subyearling Chinook salmon detected on the bird colonies were last detected by the array located adjacent to the colonies. Juvenile steelhead may have a greater tendency to migrate closer to the water surface than other salmonids (Beeman et al. 1999; Antolos et al. 2005), making them more vulnerable to predation by Caspian terns (Collis et al. 2001; Antolos et al. 2005), which feed mostly in the top-most meter of the water column (Cuthbert and Wires 1999). Additionally, steelhead are larger and contain greater energy content than all other stocks of juvenile salmonids migrating through the Columbia River estuary (Martinson et al. 1999). Therefore, avian predators may be travelling farther to target steelhead because they may be more vulnerable and provide greater energy. However, because the detection probability was low at the next two arrays downstream of Oak Point (Three Tree Point [CR049.6] and Harrington Point [CR037.3]) it is possible that fish last detected at Oak Point were actually consumed farther downstream.

The addition of autonomous receiver arrays to partition the lower Columbia River and estuary into reaches, beginning in 2007, has vastly increased our understanding of the migratory behavior and survival of juvenile salmonids emigrating through the lower $235 \mathrm{~km}$ of the Columbia River and estuary. However, because we implanted hatchery- and natural-origin run-of-the-river fish that were captured 
upstream of Bonneville Dam and measured $95 \mathrm{~mm}$ or greater, the behavior and survival of the fish used in this study may differ from that of smaller juvenile fish, many of which enter the Columbia River downstream of Bonneville Dam. These fish, particularly smaller subyearling Chinook salmon, may spend considerable amounts of time rearing in the estuary prior to emigrating to the ocean. A recent study conducted to investigate the possibility of decreasing the size of JSATS acoustic transmitters determined that significant reductions in the volume and weight of JSATS transmitters tare possible by using an application-specific integrated circuit (ASIC) to replace most of the components required for current designs (Carlson and Myjak 2010). Reduction in JSATS transmitter weight to $0.2 \mathrm{~g}$ would permit tagging fish much smaller than the current threshold of $95 \mathrm{~mm}$ fork length (down to about $70 \mathrm{~mm}$ fork length; Carlson and Myjak 2010), which would allow for studies of smaller subyearling Chinook salmon in the Columbia River estuary. Estimated survival of acoustic-tagged juvenile Chinook salmon and steelhead through the lower Columbia River and estuary in 2009 was lowest in the final $50 \mathrm{~km}$ of the estuary. Probability of survival was relatively high $(>0.90)$ for yearling and subyearling Chinook salmon from the Bonneville Dam forebay (rkm 236) to Three-Tree Point (rkm 49.6). Survival of juvenile Chinook salmon declined sharply through the lower $50 \mathrm{~km}$ of the estuary. Acoustic-tagged steelhead smolts did not survive as well as juvenile Chinook salmon between Bonneville Dam and the mouth of the Columbia River. Steelhead survival began to decline farther upstream (at Oak Point [rkm 86]) relative to that of the Chinook salmon stocks. Subyearling Chinook salmon survival decreased markedly as the season progressed. It remains to be determined whether later migrating subyearling Chinook salmon are suffering increasing mortality as the season progresses or whether some portion of the apparent loss is due to fish electing to extend their freshwater residence.

Although it was not the primary objective, this study provided the first glimpse into what promises to be a very informative way to learn more about how juvenile salmonid passage experiences through the FCRPS may influence their subsequent survival after passing Bonneville Dam. Based on the findings from these analyses, it may be worth pursuing directed objectives and full experimental designs to focus on the latent mortality of fish in the estuary after passing through particular dam passage route combinations. New information regarding the influence of migration pathway through the lower $50 \mathrm{~km}$ of the Columbia River estuary on probability of survival of juvenile salmonids, combined with increased understanding regarding the foraging distances and time periods of avian predators should prove useful in developing or assessing management actions to reduce losses of juvenile salmonid smolts that attempt to pass through the estuary on the seaward migration 


\subsection{References}

Anderson, S. K., D. D. Roby, D. E. Lyons, and K. Collis. 2005. Factors affecting chick provisioning by Caspian terns nesting in the Columbia River estuary. Estuarine, Coastal and Shelf Science 73:447-456.

Anderson, S. K., D. D. Roby, D. E. Lyons, and K. Collis. 2007. Relationship of Caspian tern foraging ecology to nesting success in the Columbia River estuary, Oregon, USA. Estuarine, Coastal and Shelf Science 73:447-456.

Antolos, M., Roby, D.D., Lyons, D.E., Collis, K., Evans, A.F., Hawbecker, M., and Ryan, B.A. 2005. Caspian tern predation on juvenile salmonids in the mid-Columbia River. Transactions of the American Fisheries Society 134:466-480.

Beeman, J.W., Robinson, T.C., Haner, P.V., Vanderkooi, S.P., and Maule, A.G. 1999. Gas bubble disease monitoring and research of juvenile salmonids. U.S. Geological Survey, Biological Resources Division, Columbia River Research Laboratory, Cook, Washington.

Buchanan, R. A., J. R. Skalski, and G. A. McMichael. 2009. Differentiating mortality from delayed migration in subyearling fall Chinook salmon (Oncorhynchus tshawytscha). Canadian Journal of Fisheries and Aquatic Sciences 66:2243-2255.

Budy, P., G. P. Thiede, N. Bouwes, C. E. Petrosky and H. Schaller. 2002. Evidence linking delayed mortality of Snake River salmon to their earlier hydrosystem experience. North American Journal of Fisheries Management 22: 35-51.

Burnham, K.P., Anderson, D.R., White, G.C., Brownie, C., and Pollock, K.H. 1987. Design and analysis methods for fish survival experiments based on release-recapture. American Fisheries Society Monograph 5.

Carlson, T. J., and M. J. Myjak. 2010. Juvenile Salmon Acoustic Telemetry System transmitter downsize assessment. Report of the Pacific Northwest National Laboratory for the U.S. Army Corps of Engineers, Portland District.

Collis, K., D. D. Roby, D. P. Craig, B. A. Ryan, and R. D. Ledgerwood. 2001. Colonial waterbird predation on juvenile salmonids tagged with passive integrated transponders in the Columbia River estuary: vulnerability of different species, stocks, and rearing types. Transactions of the American Fisheries Society 130:385-396.

Collis, K., D. D. Roby, D. P. Craig, S. Adamany, J. Adkins, and D. E. Lyons. 2002. Colony size and diet composition of piscivorous water birds on the lower Columbia River: implications for losses of juvenile salmonids to avian predation. Transactions of the American Fisheries Society 131:537-550.

Connor, W.P., Burge, H.L., Waitt, R., and Bjornn, T.C. 2002. Juvenile life history of wild fall Chinook salmon in the Snake and Clearwater rivers. North American Journal of Fisheries Management 22:702712. 
Connor, W.P., Sneva, J.G., Tiffan, K.F., Steinhorst, R.K., and Ross, D. 2005. Two alternative juvenile life history types for fall Chinook salmon in the Snake River Basin. Transactions of the American Fisheries Society 134:291-304.

Cormack, R. M. 1964. Estimates of survival from the sightings of marked animals. Biometrika 51:429438.

Cuthbert, F.J., and Wires, L.R. 1999. Caspian Tern (Sterna caspia). In The Birds of North America, No. 403. Edited by A. Poole and F. Gill. The Birds of North America, Inc., Philadelphia, Pennsylvania.

Fox, D. S., S. Bell, W. Nehlsen, and J. Damron. 1984. The Columbia River Estuary-atlas of physical and biological characteristics. Columbia River Estuary Data Development Program, Columbia River Estuary Study Task Force, Astoria, Oregon.

Ferguson, J. W., R. F. Absolon, T. J. Carlson, and B. P. Sandford. 2006. Evidence of delayed mortality on juvenile Pacific salmon passing through turbines at Columbia River dams. Transactions of the American Fisheries Society 135: 139-150.

Harnish, R.A, G.E. Johnson, G.A. McMichael, M. S. Hughes, and B. D. Ebberts. In preparation. Effects of migration pathway on survival and travel time of acoustic-tagged juvenile salmonids in the Columbia River estuary.

Hickey, B. M., S. Geier, N. Kachel, and A. MacFadyen. 2005. A bi-directional river plume: The Columbia in summer. Continental Shelf Research 25:1631-1656.

Jolly, G. M. 1965. Explicit estimates from capture-recapture data with both death and immigrationstochastic model. Biometrika 52:225-247.

Martinson, R.D., Kamps, J.W., Kovalchuk, G.M., and Ballinger, D. 1999. Monitoring of downstream salmon and steelhead at federal hydroelectric facilities - 1998. DOE/BP-20733-13, Bonneville Power Administration, Portland, Oregon.

McComas, R. L., L. Gilbreath, S. G. Smith, G. Matthews, J. W. Ferguson, G. A. McMichael, J. A. Vucelick, and T. Carlson. 2007. A study to estimate salmonids survival through the Columbia River Estuary using acoustic tags, 2005. Report of the National Marine Fisheries Service to the U.S. Army Corps of Engineers, Portland District. Available at www.nwfsc.noaa.gov/research/ divisions/fed/ acoustictag.cfm (May 2009).

McComas, R.L. G.A. McMichael, J.A. Vucelick, L. Gilbreath, J.P. Everett, S.G. Smith, T. Carlson, G. Matthews, and J.W. Ferguson. 2008. A Study to Estimate Salmonid Survival through the Columbia River Estuary using Acoustic Tags, 2006. National Marine Fisheries Service, Seattle, Washington. Available at: https://www.nwp.usace.army.mil/pm/e/afep estuary.asp.

McMichael, G. A., M. B. Eppard, T. J. Carlson, J. A. Carter, B. D. Ebberts, R. S. Brown, M. A. Weiland, G. R. Ploskey, R. A. Harnish, and Z. D. Deng. 2010. The Juvenile Salmon Acoustic Telemetry System: a new tool. Fisheries 35(1):9-22. 
Ryan, B. A., A. S. Cameron, E. P. Nunnallee, and J. W. Ferguson. 2005. Detection of passive integrated transponder (PIT) tags on piscivorous bird colonies in the Columbia River basin, 2002. Report of the National Marine Fisheries Service to the U.S. Army Corps of Engineers, Walla Walla District. Available at http://www.nwfsc.noaa.gov/publications/index.cfm (June 2009).

Roby, D. D., K. Collis, and D. E. Lyons. 2005. Conservation and management for fish eating birds and endangered salmon. Pp. 161-165 in C. J. Ralph and T. D. Rich (eds.). Bird conservation implementation and integration in the Americas: Proceedings of the Third International Partners in Flight Conference. USDA Forest Service Gen. Tech. Rep. PSW-GTR-191.

Schaller, H. A. and C. E. Petrosky. 2007. Assessing hydrosystem influence on delayed mortality of Snake River stream-type Chinook salmon. North American Journal of Fisheries Management 27:810824.

Schreck C. B. , M. D. Karnowski, and B. J. Clemens. 2005. Evaluation of Post Release Losses and Barging Strategies that Minimize Post Release Mortality. Oregon Cooperative Fishery Unit, Department of Fisheries and Wildlife, Oregon State University, Corvallis.

Schreck, C. B., T. P. Stahl, L. E. Davis, D. D. Roby, and B. J. Clemens. 2006. Mortality estimates of juvenile spring-summer Chinook salmon in the lower Columbia River and estuary, 1992-1998: Evidence for delayed mortality? Transactions of the American Fisheries Society 135:457-485.

Seber, G.A.F. 1965. A note on the multiple recapture census. Biometrika 52:249-259.

Sherwood, C. R., and J. S. Greagar. 1990. Sedimentary geology of the Columbia River estuary. Progress in Oceanography 25:15-79.

Sherwood, C. R., D. A. Jay, R. B. Harvey, P. Hamilton, and C. A. Simenstad. 1990. Historical changes in the Columbia River estuary. Progress in Oceanography 25:299-357.

Skalski, J.R., Buchanan, R.A., Townsend, R.L., Steig, T. W., and Hemstrom, S. 2009. A multiplerelease model to estimate route-specific and dam passage survival at a hydroelectric project. North American Journal of Fisheries Management. 29:670-679.

Titzler, P. S., G. A. McMichael, and J. A. Carter. 2010. Autonomous acoustic receiver deployment and mooring techniques for use in large rivers and estuaries. North American Journal of Fisheries Management 30:853-859.

Townsend, R.L., Skalski, J.R., Dillingham, P., and Steig, T.W. 2006. Correcting bias in survival estimation resulting from tag failure in acoustic and radiotelemetry studies. Journal of Agricultural Biology and Environmental Statistics 11(2):183-196.

White, S.M. 1970. Mineralogy and geochemistry of continental shelf sediments off the WashingtonOregon coast. J ournal of Sedimentary Petrology 40(1):38-54.

Woxell, L.K. 1998. Prehistoric beach accretion rates and long-term response to sediment depletion in the Columbia River Littoral System. Portland State University, Oregon. 

Appendix A

Acoustic-Tagged Fish Releases 



\section{Appendix A}

\section{Acoustic-Tagged Fish Releases}

Table A.1. Numbers and size of acoustic-tagged yearling Chinook salmon released in the Columbia River near Roosevelt, WA (rkm 387) in 2009.

\begin{tabular}{|c|c|c|c|c|c|c|c|}
\hline $\begin{array}{l}\text { Release } \\
\text { date }\end{array}$ & $\mathrm{N}$ & $\begin{array}{c}\text { Mean (SE) } \\
\text { FL }(\mathrm{mm})\end{array}$ & $\begin{array}{l}\text { Min FL } \\
(\mathrm{mm})\end{array}$ & $\begin{array}{c}\operatorname{Max} F L \\
(\mathrm{~mm})\end{array}$ & $\begin{array}{c}\text { Mean } \\
\text { weight }(\mathrm{g})\end{array}$ & $\begin{array}{l}\text { Min weight } \\
\text { (g) }\end{array}$ & $\begin{array}{l}\text { Max weight } \\
\text { (g) }\end{array}$ \\
\hline April 27 & 114 & $161.0(1.6)$ & 121 & 196 & $39.5(1.2)$ & 16.7 & 72.2 \\
\hline April 28 & 116 & $153.0(1.4)$ & 120 & 190 & $33.7(1.0)$ & 16.9 & 69.8 \\
\hline April 29 & 116 & $157.1(1.5)$ & 128 & 198 & $36.3(1.1)$ & 16.4 & 65.9 \\
\hline April 30 & 115 & $154.8(1.7)$ & 120 & 201 & $35.3(1.2)$ & 13.5 & 67.6 \\
\hline May 1 & 115 & $161.0(1.9)$ & 115 & 216 & $39.4(1.4)$ & 13.5 & 89.8 \\
\hline May 2 & 115 & $152.7(1.8)$ & 118 & 221 & $33.4(1.3)$ & 14.2 & 94.5 \\
\hline May 3 & 117 & $152.5(1.7)$ & 120 & 191 & $34.2(1.2)$ & 16.5 & 68.8 \\
\hline May 4 & 116 & $156.3(1.6)$ & 122 & 200 & $36.6(1.1)$ & 16.7 & 70.9 \\
\hline May 5 & 116 & $153.9(1.8)$ & 118 & 215 & $34.9(1.2)$ & 14.7 & 85.9 \\
\hline May 6 & 116 & $153.8(1.6)$ & 118 & 200 & $35.0(1.2)$ & 15.9 & 73.6 \\
\hline May 7 & 114 & $152.6(1.9)$ & 115 & 224 & $32.8(1.3)$ & 14.1 & 94.6 \\
\hline May 8 & 115 & $147.8(1.6)$ & 111 & 195 & $32.3(1.2)$ & 13.9 & 72.3 \\
\hline May 9 & 115 & $150.1(1.7)$ & 116 & 200 & $31.6(1.1)$ & 14.4 & 71.5 \\
\hline May 10 & 117 & $144.8(1.9)$ & 109 & 212 & $30.4(1.4)$ & 11.2 & 95.2 \\
\hline May 11 & 115 & $143.3(1.9)$ & 110 & 201 & $28.8(1.3)$ & 11.7 & 76.6 \\
\hline May 12 & 116 & $145.2(1.9)$ & 112 & 201 & $30.0(1.3)$ & 12.6 & 76.8 \\
\hline May 13 & 115 & $144.0(1.9)$ & 110 & 211 & $28.7(1.3)$ & 12.5 & 87.3 \\
\hline May 14 & 116 & $142.2(2.0)$ & 102 & 208 & $28.4(1.4)$ & 11.1 & 85.9 \\
\hline May 15 & 115 & $140.5(1.9)$ & 105 & 203 & $26.3(1.2)$ & 9.9 & 75.7 \\
\hline May 16 & 115 & $140.3(1.5)$ & 107 & 178 & $26.0(0.9)$ & 10.7 & 52.9 \\
\hline May 17 & 114 & $139.5(1.8)$ & 104 & 200 & $27.3(1.2)$ & 10.1 & 85.2 \\
\hline May 18 & 117 & $145.3(1.8)$ & 104 & 197 & $31.2(1.3)$ & 11 & 76.7 \\
\hline May 19 & 118 & $144.1(1.6)$ & 103 & 208 & $29.7(1.1)$ & 12.9 & 86.1 \\
\hline May 20 & 116 & $148.1(1.9)$ & 105 & 209 & $32.5(1.5)$ & 9.5 & 91.9 \\
\hline May 21 & 115 & $150.7(1.8)$ & 111 & 210 & $32.4(1.4)$ & 13.2 & 85.9 \\
\hline May 22 & 115 & $144.3(1.4)$ & 116 & 200 & $29.1(1.0)$ & 13 & 88.2 \\
\hline May 23 & 111 & $144.7(1.5)$ & 113 & 197 & $28.8(1.1)$ & 14 & 78.9 \\
\hline May 24 & 120 & $145.9(1.5)$ & 119 & 196 & $30.3(1.0)$ & 16.7 & 75.4 \\
\hline May 25 & 120 & $146.7(1.6)$ & 117 & 207 & $30.2(1.2)$ & 14.5 & 84.9 \\
\hline May 26 & 115 & $142.8(1.4)$ & 111 & 190 & $27.6(0.9)$ & 11.9 & 66.5 \\
\hline
\end{tabular}


Table A.2. Numbers and size of acoustic-tagged steelhead released in the Columbia River near Roosevelt, WA (rkm 387) in 2009.

\begin{tabular}{|c|c|c|c|c|c|c|c|}
\hline $\begin{array}{l}\text { Release } \\
\text { date }\end{array}$ & $\mathrm{N}$ & $\begin{array}{l}\text { Mean (SE) FL } \\
(\mathrm{mm})\end{array}$ & $\begin{array}{l}\text { Min FL } \\
(\mathrm{mm})\end{array}$ & $\begin{array}{c}\operatorname{Max} F L \\
(\mathrm{~mm})\end{array}$ & $\begin{array}{c}\text { Mean } \\
\text { weight }(\mathrm{g})\end{array}$ & $\begin{array}{l}\text { Min weight } \\
(\mathrm{g})\end{array}$ & $\begin{array}{l}\text { Max weight } \\
\text { (g) }\end{array}$ \\
\hline April 27 & 115 & $199.3(2.5)$ & 154 & 268 & $72.3(2.9)$ & 29.3 & 155.8 \\
\hline April 28 & 116 & $210.1(2.3)$ & 146 & 262 & $81.5(2.5)$ & 23.4 & 153.3 \\
\hline April 29 & 115 & $212.4(2.4)$ & 138 & 273 & $84.8(2.8)$ & 23.6 & 183.1 \\
\hline April 30 & 116 & $216.2(2.1)$ & 152 & 258 & $88.2(2.4)$ & 27.3 & 159.1 \\
\hline May 1 & 110 & $212.0(2.2)$ & 146 & 255 & $82.5(2.4)$ & 33.1 & 136.9 \\
\hline May 2 & 116 & $213.9(1.7)$ & 168 & 255 & $84.0(2.1)$ & 39.3 & 138.1 \\
\hline May 3 & 120 & $212.3(1.7)$ & 170 & 251 & $82.6(2.1)$ & 40.7 & 149.4 \\
\hline May 4 & 116 & $218.5(1.7)$ & 164 & 253 & $89.5(2.2)$ & 34.2 & 140.2 \\
\hline May 5 & 116 & $211.6(1.6)$ & 160 & 248 & $79.2(1.8)$ & 32.3 & 125 \\
\hline May 6 & 116 & $210.4(1.9)$ & 158 & 256 & $80.0(2.2)$ & 35.4 & 142.8 \\
\hline May 7 & 115 & $215.5(1.4)$ & 176 & 255 & $81.6(1.8)$ & 43.4 & 147 \\
\hline May 8 & 116 & $208.7(1.9)$ & 160 & 257 & $77.9(2.1)$ & 32.7 & 142.5 \\
\hline May 9 & 115 & $205.5(2.1)$ & 156 & 258 & $73.7(2.3)$ & 33.4 & 139.2 \\
\hline May 10 & 116 & 207.4 (1.9) & 156 & 257 & $76.6(2.1)$ & 29.7 & 149.1 \\
\hline May 11 & 115 & $203.6(2.3)$ & 136 & 252 & $72.3(2.3)$ & 22.4 & 135.2 \\
\hline May 12 & 116 & $213.9(2.1)$ & 137 & 259 & $83.6(2.5)$ & 24.4 & 165.4 \\
\hline May 13 & 115 & $206.3(2.1)$ & 151 & 253 & $72.0(2.1)$ & 29.2 & 130.8 \\
\hline May 14 & 116 & $210.6(2.0)$ & 155 & 256 & $79.0(2.1)$ & 33.4 & 139.9 \\
\hline May 15 & 104 & $210.0(2.2)$ & 142 & 250 & $76.3(2.2)$ & 26.2 & 127.9 \\
\hline May 16 & 120 & $209.2(2.1)$ & 156 & 258 & $75.7(2.2)$ & 26.9 & 141.2 \\
\hline May 17 & 120 & $208.2(2.1)$ & 156 & 253 & $77.3(2.1)$ & 33.5 & 138.4 \\
\hline May 18 & 118 & $209.9(2.1)$ & 154 & 259 & $81.4(2.4)$ & 32.8 & 153.7 \\
\hline May 19 & 116 & $207.9(2.2)$ & 147 & 259 & $77.7(2.3)$ & 27.6 & 150.1 \\
\hline May 20 & 116 & $212.5(2.2)$ & 146 & 252 & $83.8(2.5)$ & 25.7 & 155.7 \\
\hline May 21 & 115 & $210.8(2.2)$ & 141 & 258 & $76.8(2.3)$ & 22.9 & 137.9 \\
\hline May 22 & 116 & $207.1(2.2)$ & 161 & 258 & $75.6(2.2)$ & 36.3 & 139.1 \\
\hline May 23 & 113 & $209.2(2.7)$ & 119 & 259 & $78.7(2.6)$ & 28.2 & 146.6 \\
\hline May 24 & 118 & $206.7(2.6)$ & 141 & 253 & $76.8(2.5)$ & 26.6 & 150.2 \\
\hline May 25 & 119 & $207.9(2.5)$ & 151 & 254 & $77.4(2.5)$ & 28.1 & 134.1 \\
\hline May 26 & 116 & $210.9(2.5)$ & 150 & 260 & $77.6(2.6)$ & 28 & 152.7 \\
\hline
\end{tabular}


Table A.3. Numbers and size of acoustic-tagged subyearling released in the Columbia River near Roosevelt, WA (rkm 387) in 2009.

\begin{tabular}{|c|c|c|c|c|c|c|c|}
\hline $\begin{array}{l}\text { Release } \\
\text { date }\end{array}$ & $\mathrm{N}$ & $\begin{array}{l}\text { Mean (SE) FL } \\
(\mathrm{mm})\end{array}$ & $\begin{array}{l}\operatorname{Min} F L \\
(\mathrm{~mm})\end{array}$ & $\begin{array}{c}\operatorname{Max} F L \\
(\mathrm{~mm})\end{array}$ & $\begin{array}{c}\text { Mean } \\
\text { weight }(g)\end{array}$ & $\begin{array}{l}\text { Min weight } \\
(\mathrm{g})\end{array}$ & $\begin{array}{l}\text { Max weight } \\
\text { (g) }\end{array}$ \\
\hline June 16 & 114 & $115.7(0.6)$ & 101 & 131 & $15.1(0.3)$ & 9.4 & 23.3 \\
\hline June 17 & 117 & $115.1(0.6)$ & 103 & 137 & $14.9(0.3)$ & 9.3 & 28.9 \\
\hline June 18 & 115 & $116.6(0.7)$ & 95 & 136 & $15.9(0.4)$ & 7.1 & 30 \\
\hline June 19 & 115 & $114.2(0.6)$ & 102 & 130 & $14.2(0.3)$ & 9.4 & 22.6 \\
\hline June 20 & 113 & $110.8(0.7)$ & 98 & 131 & $13.6(0.3)$ & 9 & 25 \\
\hline June 21 & 116 & $109.0(0.7)$ & 95 & 138 & $13.1(0.3)$ & 8.3 & 31.7 \\
\hline June 22 & 115 & $108.9(0.7)$ & 95 & 140 & $13.0(0.3)$ & 8.4 & 33 \\
\hline June 23 & 118 & $108.1(0.6)$ & 96 & 126 & $12.4(0.2)$ & 8.4 & 20 \\
\hline June 24 & 116 & $107.3(0.6)$ & 96 & 128 & $12.1(0.3)$ & 8.5 & 22.7 \\
\hline June 25 & 117 & $107.5(0.6)$ & 97 & 136 & $12.1(0.3)$ & 7.6 & 25.3 \\
\hline June 26 & 115 & $107.6(0.7)$ & 95 & 142 & $12.4(0.3)$ & 8 & 31.1 \\
\hline June 27 & 116 & $108.0(0.5)$ & 98 & 124 & $13.2(0.2)$ & 9.2 & 20.4 \\
\hline June 28 & 115 & $109.2(0.5)$ & 95 & 125 & $12.6(0.2)$ & 8.9 & 20 \\
\hline June 29 & 116 & $107.2(0.4)$ & 98 & 122 & $12.1(0.2)$ & 8.6 & 17.8 \\
\hline June 30 & 115 & $108.4(0.5)$ & 96 & 134 & $12.6(0.2)$ & 8.8 & 24.2 \\
\hline July 1 & 116 & $108.8(0.5)$ & 98 & 136 & $12.7(0.2)$ & 8.9 & 26.2 \\
\hline July 2 & 114 & $108.9(0.6)$ & 95 & 136 & $12.6(0.2)$ & 8.2 & 26.2 \\
\hline July 3 & 116 & $109.3(0.6)$ & 100 & 145 & $12.8(0.3)$ & 9.3 & 29.7 \\
\hline July 4 & 115 & $108.7(0.6)$ & 98 & 147 & $12.5(0.2)$ & 8.1 & 29.9 \\
\hline July 5 & 113 & $108.3(0.8)$ & 95 & 158 & $12.9(0.5)$ & 8.2 & 47.4 \\
\hline July 6 & 114 & $109.6(0.6)$ & 97 & 129 & $13.6(0.3)$ & 9 & 23.8 \\
\hline July 7 & 119 & $110.9(0.6)$ & 96 & 134 & $14.1(0.3)$ & 8.7 & 25.7 \\
\hline July 8 & 115 & $111.9(0.7)$ & 99 & 149 & $14.6(0.3)$ & 9.5 & 33 \\
\hline July 9 & 116 & $111.8(0.5)$ & 101 & 136 & $14.2(0.2)$ & 9.3 & 24.8 \\
\hline July 10 & 94 & $112.6(0.7)$ & 102 & 136 & $14.9(0.3)$ & 10.5 & 26.3 \\
\hline July 11 & 120 & $113.8(0.7)$ & 100 & 153 & $14.7(0.3)$ & 9.7 & 37.7 \\
\hline July 12 & 118 & $110.7(0.5)$ & 96 & 124 & $14.3(0.2)$ & 10.3 & 21 \\
\hline July 13 & 120 & $111.9(0.7)$ & 96 & 144 & $14.8(0.3)$ & 8.8 & 33.6 \\
\hline July 14 & 118 & $110.5(0.8)$ & 101 & 152 & $14.4(0.4)$ & 9.7 & 38.9 \\
\hline July 15 & 120 & $112.5(1.1)$ & 98 & 161 & $15.6(0.6)$ & 8.7 & 47.7 \\
\hline
\end{tabular}



Appendix B

Autonomous Receiver Locations 



\section{Appendix B}

\section{Autonomous Receiver Locations}

Table B.1. Locations and sampling durations of single acoustic telemetry receivers and receiver arrays used to monitor survival and behavior of acoustic-tagged yearling and subyearling Chinook salmon and steelhead migrating from the forebay of Bonneville Dam to the mouth of the Columbia River in 2009.

\begin{tabular}{|c|c|c|c|c|c|}
\hline rkm & Physical site description & Array ID & $\begin{array}{l}\text { Number of } \\
\text { receivers }\end{array}$ & $\begin{array}{c}\text { Date } \\
\text { deployed }\end{array}$ & $\begin{array}{c}\text { Date } \\
\text { retrieved }\end{array}$ \\
\hline 236.0 & Bonneville Dam forebay & CR236.0 & 4 & 22-Apr & 20-Aug \\
\hline 192.0 & Bonneville Dam tailrace, Lady Island & CR192.0 & 9 & 23-Apr & 20-Aug \\
\hline 113.0 & Kalama, Cottonwood Island & CR113.0 & 9 & 24-Apr & 25-Aug \\
\hline 86.2 & Oak Point & CR086.2 & 6 & 24-Apr & 25-Aug \\
\hline 49.6 & Three Tree Point & CR049.6 & 3 & 24-Apr & 25-Aug \\
\hline 37.3 & Harrington Point & CR037.3 & 4 & 24-Apr & 25-Aug \\
\hline 34.0 & Grays Bay, Rocky Point & CR034.0 (a) & 2 & 24-Apr & 26-Aug \\
\hline 29.3 & Grays Bay, Grays Point & CR029.3 $3^{(\mathrm{a})}$ & 1 & 24-Apr & $18-\mathrm{Jul}^{(\mathrm{b})}$ \\
\hline 22.0 & Astoria Bridge & CR022.0 & 17 & 26-Apr & 26-Aug \\
\hline 8.3 & Estuary primary, East Sand Island & CR008.3 & 22 & 25-Apr & 27-Aug \\
\hline 2.8 & Estuary secondary, between north and south Jetties & CR002.8 & 27 & 25-Apr & 26-Aug \\
\hline
\end{tabular}

(a) Single receivers were deployed at these locations and were not considered arrays. Survival was not estimated to these locations.

(b) Receiver was not recovered in August. 



\section{Appendix C}

\section{Tag Life and Tag-Life Adjusted Detection Probability and Survival Estimates}





\section{Appendix C}

\section{Tag Life and Tag-Life Adjusted Detection Probability and Survival Estimates}

\section{C.1 Analysis Objective}

The objective of this analysis was to determine whether the Cormack-Jolly-Seber (CJS) survival estimates from the 2009 POST-FCRPS should be adjusted for the acoustic tag life probability. Survival and detection probability estimates for fish migrating from the Bonneville Dam forebay array (CR236.0) to the East Sand Island array (CR008.3) were considered to be most likely to be affected by premature tag failures, due to the long travel times, and if these estimates did not need to be adjusted for tag-life (or adjustments were very small), then the unadjusted CJS estimates would be adequate to describe the study results. Unadjusted and adjusted estimates were calculated and compared for each virtual release group of yearling and subyearling Chinook salmon and steelhead.

\section{C.2 Tag-Life Corrections}

Parametric models did not adequately describe the tag-life curve (Figure C.1); therefore, the nonparametric Kaplan-Meier method (Kaplan and Meier 1958) was used to summarize the tag-life data. Corrections for tag life were based on the method in Townsend et al. (2006).

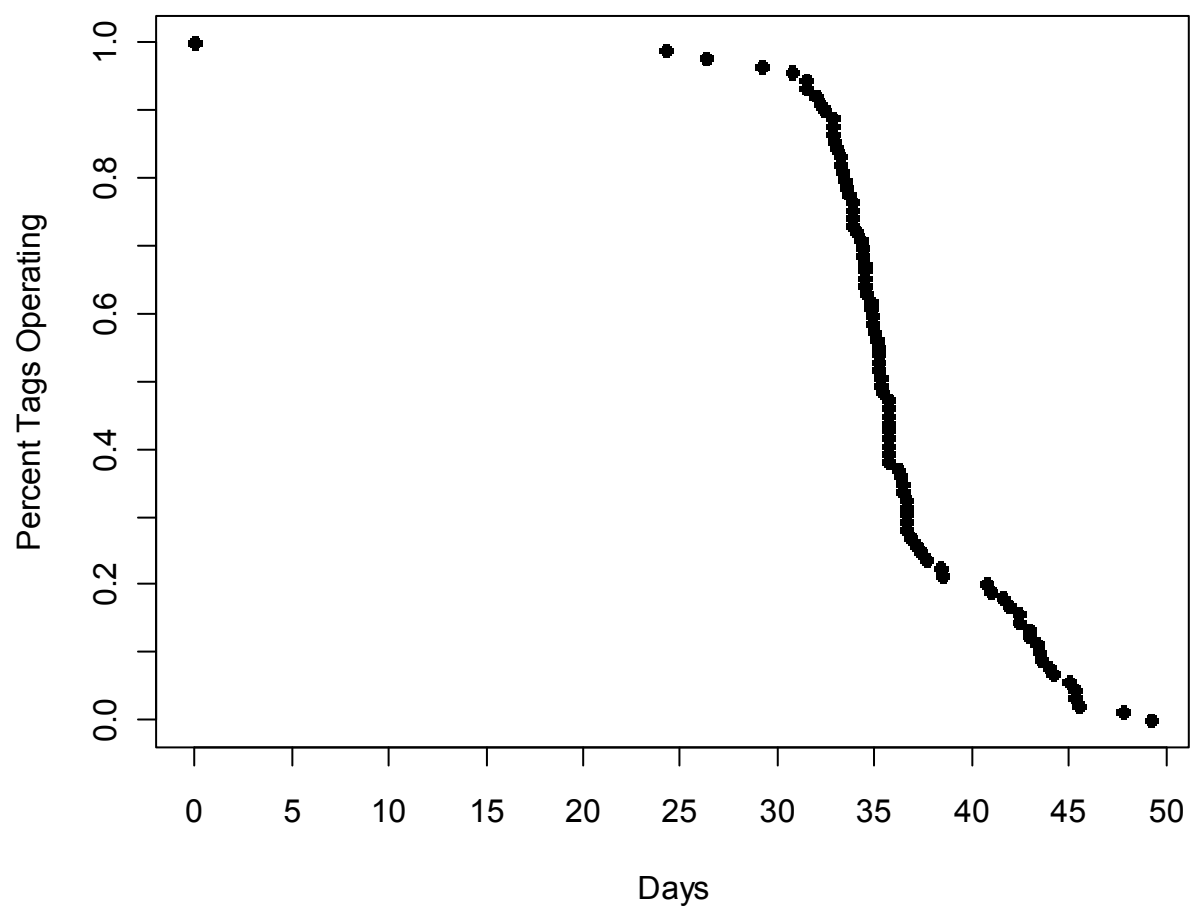

Figure C.1. Results from 2009 tag-life study. The percentage of tags operating is plotted against time. The "bump" occurring around day 36 indicates another failure process kicked in, making a parametric fit to the curve difficult. 


\section{C.3 Results}

Of the 15 survival estimates (CR236.0 to CR008.3), only 1 showed an increase of 0.001 or greater $(\hat{S}=0.0013$; steelhead, week 3$)$ after the tag-life adjustment (Table $\mathrm{X})$. The joint probability of surviving from CR236.0 to CR008.3 and being detected there $(\lambda)$ had 0 of the 15 releases showing a correction of 0.001 or greater difference, ranging from -0.0004 to 0.0007 . A negative correction occurs when the average travel time to the lower array is less than that of the previous array. This can occur when only the faster fish are detected at later sites, the slowest not being observed later on. The probability of detection does not change with the tag-life correction.

Table C.1. Unadjusted and tag-life adjusted Cormack-Jolly-Seber (CJS) survival (S), detection probability (p), and joint probability of survival and detection $(\lambda)$ estimates for acoustictagged yearling and subyearling Chinook salmon and steelhead from the Bonneville Dam forebay array (CR236.0) to the East Sand Island array (CR008.3) in 2009. Shaded cells indicate differences between the adjusted and unadjusted estimates.

\begin{tabular}{|c|c|c|c|c|c|c|}
\hline \multirow[b]{2}{*}{ Week } & \multicolumn{3}{|c|}{ Unadjusted CJS } & \multicolumn{3}{|c|}{ Adjusted CJS for estimated tag-life } \\
\hline & $\mathrm{S}(\mathrm{SE})$ & $\mathrm{p}(\mathrm{SE})$ & $\lambda(\mathrm{SE})$ & S (s.e.) & p (s.e.) & $\lambda(\mathrm{SE})$ \\
\hline \multicolumn{7}{|c|}{ Yearling Chinook salmon } \\
\hline $4 / 30-5 / 6$ & $0.8040(0.0236)$ & $0.8486(0.0243)$ & $0.5781(0.0276)$ & $0.08060(0.0237)$ & $0.8486(0.0243)$ & $0.5788(0.0276)$ \\
\hline $5 / 7-5 / 13$ & $0.8061(0.0174)$ & $0.8693(0.0174)$ & $0.5660(0.0207)$ & $0.8061(0.0174)$ & $0.8693(0.0174)$ & $0.5660(0.0207)$ \\
\hline $5 / 14-5 / 20$ & $0.7384(0.0175)$ & $0.9035(0.0153)$ & $0.6647(0.0210)$ & $0.7384(0.0175)$ & $0.9035(0.0153)$ & $0.6647(0.0210)$ \\
\hline $5 / 21-5 / 27$ & $0.7905(0.0218)$ & $0.7764(0.0232)$ & $0.5388(0.0231)$ & $0.7906(0.0218)$ & $0.7764(0.0232)$ & $0.5388(0.0231)$ \\
\hline $5 / 28-6 / 2$ & $0.8462(0.0318)$ & $0.9231(0.0279)$ & $0.6364(0.0419)$ & $0.8469(0.0319)$ & $0.9231(0.0279)$ & $0.6360(0.0418)$ \\
\hline \multicolumn{7}{|c|}{ Subyearling Chinook salmon } \\
\hline $6 / 18-6 / 24$ & $0.7842(0.0258)$ & $0.8274(0.0269)$ & $0.5380(0.0286)$ & $0.7842(0.0258)$ & $0.8274(0.0269)$ & $0.5380(0.0286)$ \\
\hline $6 / 25-7 / 1$ & $0.6618(0.0220)$ & $0.9632(0.0137)$ & $0.5719(0.0277)$ & $0.6618(0.0220)$ & $0.9632(0.0137)$ & $0.5719(0.0277)$ \\
\hline $7 / 2-7 / 8$ & $0.6706(0.0240)$ & $0.9270(0.0195)$ & $0.5978(0.0295)$ & $0.6706(0.0240)$ & $0.9270(0.0195)$ & $0.5979(0.0295)$ \\
\hline $7 / 9-7 / 15$ & $0.5182(0.0249)$ & $0.9252(0.0217)$ & $0.6476(0.0330)$ & $0.5184(0.0249)$ & $0.9252(0.0217)$ & $0.6475(0.0330)$ \\
\hline $7 / 16-7 / 23$ & $0.3614(0.0421)$ & $0.8788(0.0568)$ & $0.6170(0.0709)$ & $0.3615(0.0421)$ & $0.8788(0.0568)$ & $0.6171(0.0709)$ \\
\hline \multicolumn{7}{|c|}{ Steelhead } \\
\hline $4 / 29-5 / 5$ & $0.5965(0.0280)$ & $0.8095(0.0324)$ & $0.5265(0.0332)$ & $0.5965(0.0280)$ & $0.8095(0.0324)$ & $0.5265(0.0332)$ \\
\hline $5 / 6-5 / 12$ & $0.5331(0.0195)$ & $0.8740(0.0208)$ & $0.6016(0.0255)$ & $0.5331(0.0195)$ & $0.8740(0.0208)$ & $0.6017(0.0255)$ \\
\hline $5 / 13-5 / 19$ & $0.5240(0.0201)$ & $0.8500(0.0221)$ & $0.6863(0.0259)$ & $0.5253(0.0201)$ & $0.8500(0.0221)$ & $0.6867(0.0259)$ \\
\hline $5 / 20-5 / 26$ & $0.4716(0.0213)$ & $0.7941(0.0283)$ & $0.5806(0.0295)$ & $0.4716(0.0213)$ & $0.7941(0.0283)$ & $0.5807(0.0295)$ \\
\hline $5 / 27-6 / 8$ & $0.5581(0.0317)$ & $0.8829(0.0305)$ & $0.7259(0.0384)$ & $0.5581(0.0317)$ & $0.8829(0.0305)$ & $0.7259(0.0384)$ \\
\hline
\end{tabular}

The probabilities of tags being active when fish arrived at the East Sand Island (CR008.3) and Columbia River Bar (CR002.8) arrays ranged from 99.75\% (steelhead, week 3) to 100\% among the release groups and reaches (Table C.2). For most of the releases, all the fish arrived prior to the time of the first tag failed in the tag-life study (24.25 days; Figures C.2 through C.4). Those arrival times longer than 24.25 days resulted in very small corrections to the unadjusted CJS estimates. 
Table C.2. Average probability acoustic tags were still active when fish arrived at the East Sand Island (CR008.3) and Columbia River Bar (CR002.8) arrays.

\begin{tabular}{lcc}
\hline & \multicolumn{2}{c}{ Detection array } \\
\cline { 2 - 3 } Virtual release week & CR008.3 & CR002.8 \\
\hline & Yearling Chinook salmon \\
$4 / 30-5 / 6$ & $0.9976(0.0002)$ & $0.9964(0.0002)$ \\
$5 / 7-5 / 13$ & $1.0000(<0.0001)$ & $1.0000(<0.0001)$ \\
$5 / 14-5 / 20$ & $1.0000(<0.0001)$ & $1.0000(<0.0001)$ \\
$5 / 21-5 / 27$ & $0.9999(0.0001)$ & $1.0000(<0.0001)$ \\
$5 / 28-6 / 2$ & $0.9991(0.0004)$ & $0.9998(0.0002)$ \\
& Subyearling Chinook salmon & \\
$6 / 18-6 / 24$ & $1.0000(<0.0001)$ & $0.9999(0.0001)$ \\
$6 / 25-7 / 1$ & $1.0000(<0.0001)$ & $1.0000(<0.0001)$ \\
$7 / 2-7 / 8$ & $1.0000(<0.0001)$ & $0.9999(0.0001)$ \\
$7 / 9-7 / 15$ & $0.9997(0.0001)$ & $0.9998(0.0001)$ \\
$7 / 16-7 / 23$ & $0.9998(0.0002)$ & $0.9997(0.0004)$ \\
& Steelhead & \\
$4 / 29-5 / 5$ & $1.0000(<0.0001)$ & $1.0000(<0.0001)$ \\
$5 / 6-5 / 12$ & $0.9998(0.0001)$ & $0.9998(0.0001)$ \\
$5 / 13-5 / 19$ & $0.9975(0.0002)$ & $0.9969(0.0002)$ \\
$5 / 20-5 / 26$ & $0.9999(0.0001)$ & $0.9999(0.0001)$ \\
$5 / 27-6 / 8$ & $1.0000(<0.0001)$ & $1.0000(<0.0001)$ \\
\hline
\end{tabular}



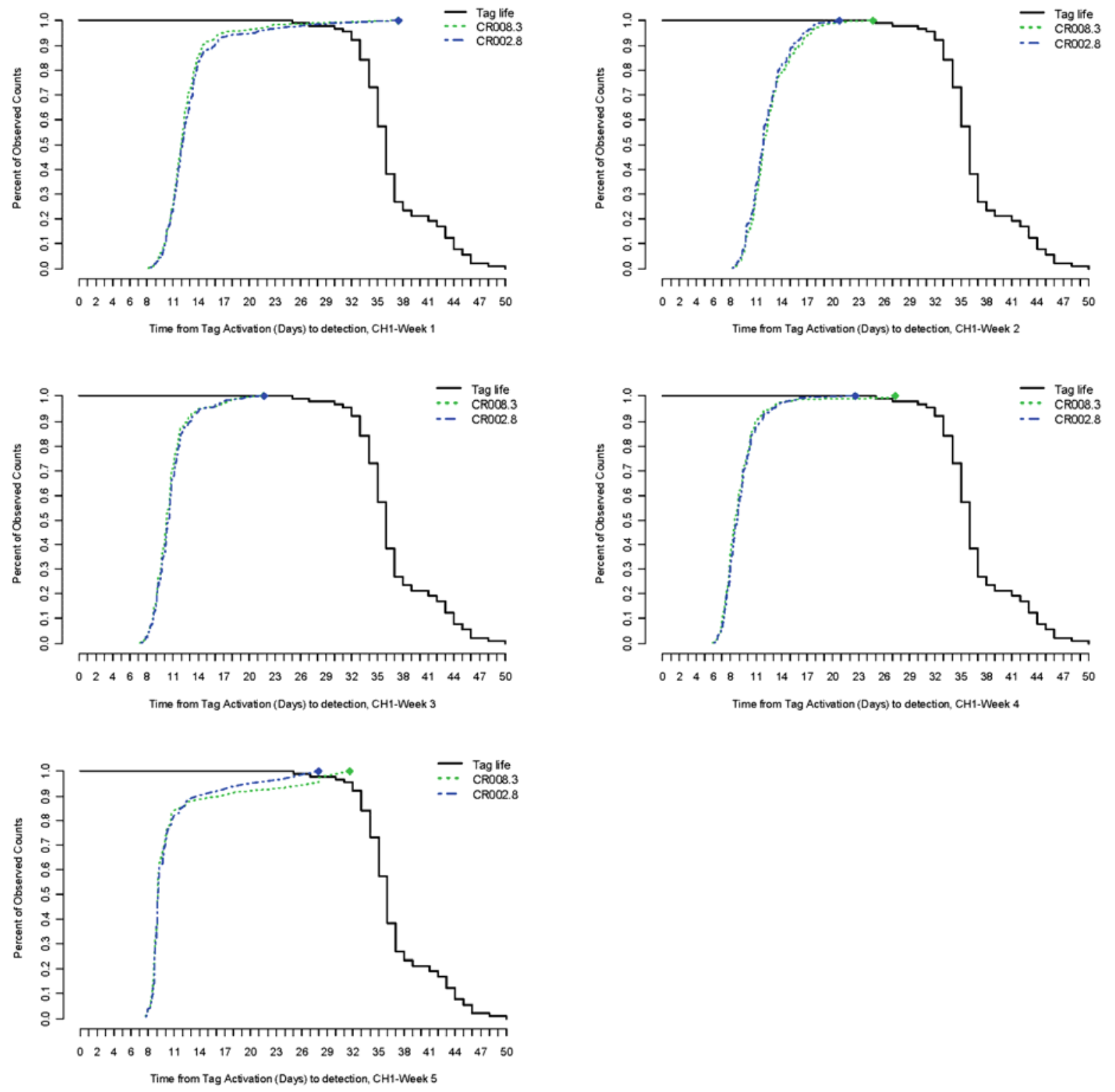

Figure C.2. Tag-life curve plotted against the distribution of travel times (from time of tag activation to detection at the East Sand Island [CR008.3] and Columbia River Bar [CR002.8] arrays) for each virtual release group of acoustic-tagged yearling Chinook salmon released near Roosevelt, Washington, in 2009. 

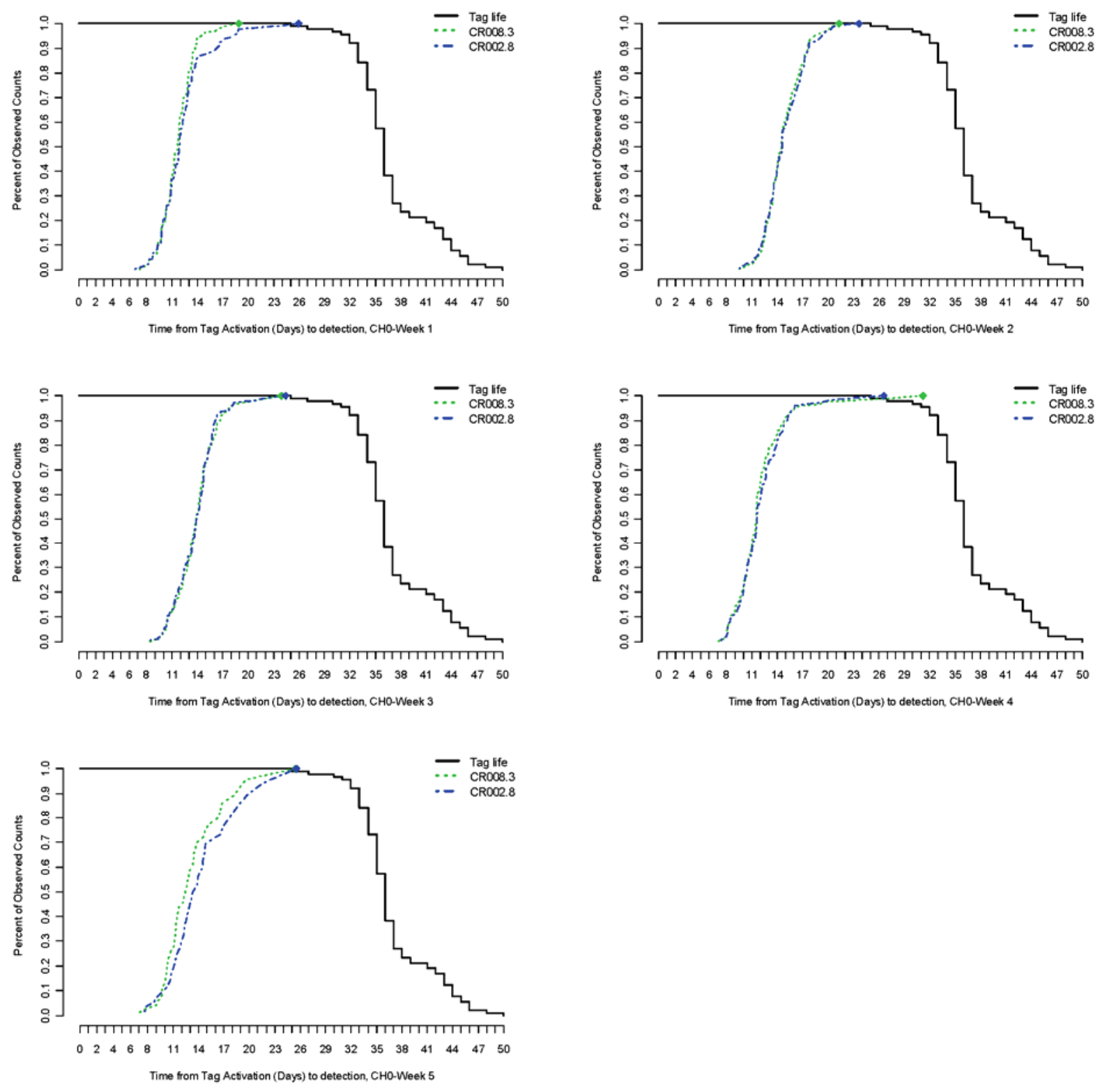

Figure C.3. Tag-life curve plotted against the distribution of travel times (from time of tag activation to detection at the East Sand Island [CR008.3] and Columbia River Bar [CR002.8] arrays) for each virtual release group of acoustic-tagged subyearling Chinook salmon released near Roosevelt, Washington, in 2009. 

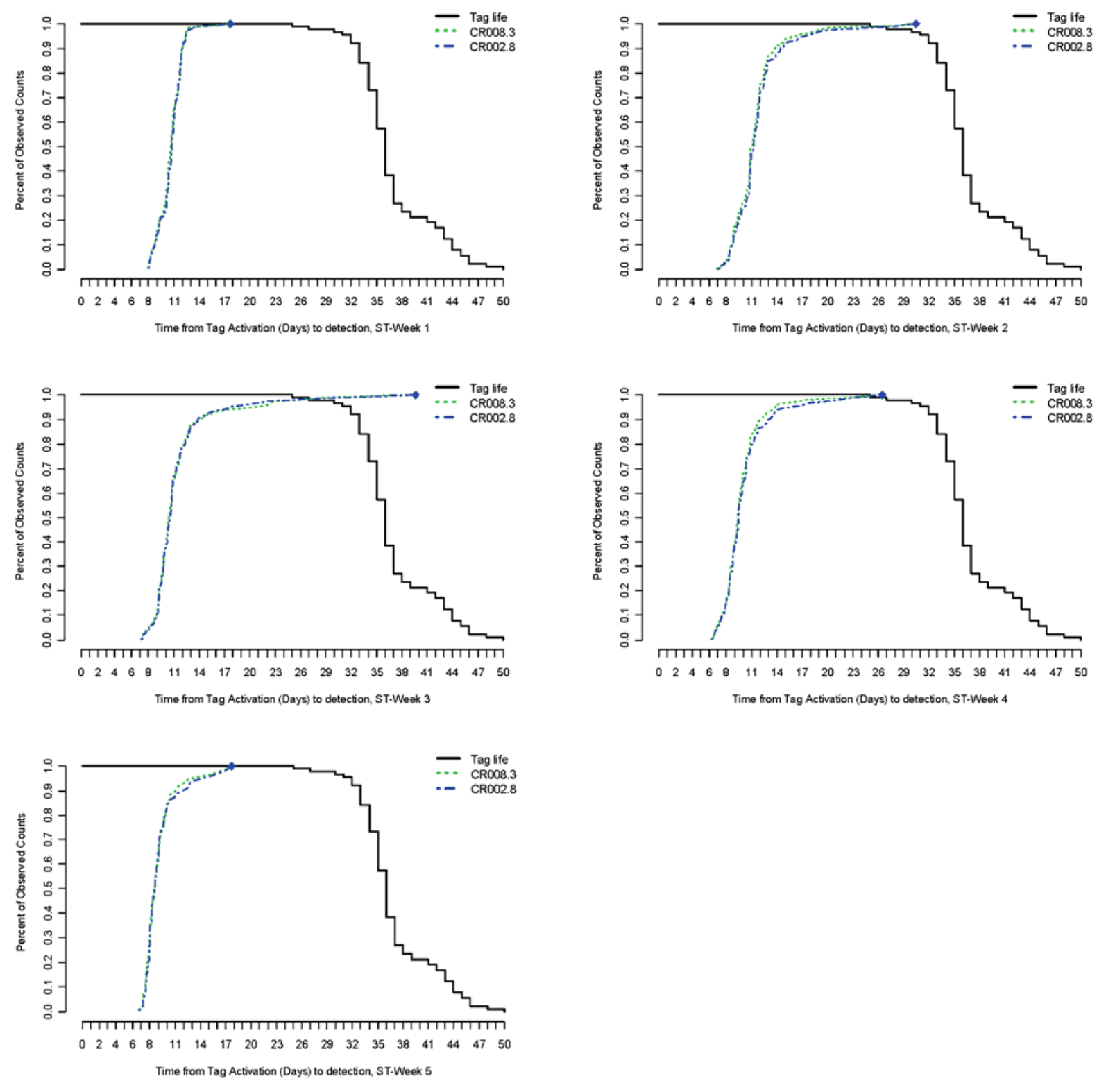

Figure C.4. Tag-life curve plotted against the distribution of travel times (from time of tag activation to detection at the East Sand Island [CR008.3] and Columbia River Bar [CR002.8] arrays) for each virtual release group of acoustic-tagged steelhead released near Roosevelt, Washington, in 2009.

\section{C.4 Literature Cited}

Kaplan, E.L., and Meier, P. 1958. Non-parametric estimation from incomplete observations. Journal of the American Statistical Association 53:457-481.

Townsend, R.L., Skalski, J.R., Dillingham, P., and Steig, T.W. 2006. Correcting bias in survival estimation resulting from tag failure in acoustic and radiotelemetry studies. Journal of Agricultural Biology and Environmental Statistics 11(2):183-196. 


\section{Appendix D}

\section{Unadjusted Detection Probability and Survival Estimates}





\section{Appendix D}

\section{Unadjusted Detection Probability and Survival Estimates}

Table D.1. Numbers of acoustic-tagged yearling and subyearling Chinook salmon and steelhead in each virtual release group and the detection probability of each group at each detection array downstream of Bonneville Dam. Standard errors of detection probability estimates are displayed in parentheses below each estimate.

\begin{tabular}{|c|c|c|c|c|c|c|c|c|}
\hline $\begin{array}{l}\text { Virtual release } \\
\text { week }\end{array}$ & $\mathrm{N}$ & CR192.0 & CR113.0 & CR086.2 & CR049.6 & CR037.3 & CR022.0 & CR008.3 \\
\hline \multicolumn{9}{|c|}{ Yearling Chinook salmon } \\
\hline $4 / 30-5 / 6$ & 469 & $0.99(0.00)$ & $0.92(0.01)$ & $0.98(0.01)$ & $0.44(0.02)$ & $0.49(0.03)$ & $0.76(0.02)$ & $0.85(0.02)$ \\
\hline $5 / 7-5 / 13$ & 822 & $0.97(0.01)$ & $0.92(0.01)$ & $0.97(0.01)$ & $0.51(0.02)$ & $0.60(0.02)$ & $0.78(0.02)$ & $0.87(0.02)$ \\
\hline $5 / 14-5 / 20$ & 760 & $0.90(0.01)$ & $0.90(0.01)$ & $0.96(0.01)$ & $0.57(0.02)$ & $0.62(0.02)$ & $0.72(0.02)$ & $0.90(0.02)$ \\
\hline $5 / 21-5 / 27$ & 756 & $0.86(0.01)$ & $0.95(0.01)$ & $0.86(0.01)$ & $0.57(0.02)$ & $0.48(0.02)$ & $0.69(0.02)$ & $0.78(0.02)$ \\
\hline $5 / 28-6 / 2$ & 169 & $0.80(0.03)$ & $0.90(0.02)$ & $0.89(0.02)$ & $0.71(0.04)$ & $0.60(0.04)$ & $0.71(0.04)$ & $0.92(0.03)$ \\
\hline Pooled & 2976 & $0.92(0.01)$ & $0.92(0.01)$ & $0.94(0.00)$ & $0.54(0.01)$ & $0.56(0.01)$ & $0.74(0.01)$ & $0.86(0.01)$ \\
\hline \multicolumn{9}{|c|}{ Steelhead } \\
\hline $4 / 29-5 / 5$ & 468 & $0.99(0.00)$ & $0.93(0.01)$ & $0.95(0.01)$ & $0.33(0.03)$ & $0.49(0.03)$ & $0.63(0.03)$ & $0.81(0.03)$ \\
\hline $5 / 6-5 / 12$ & 792 & $0.97(0.01)$ & $0.93(0.01)$ & $0.93(0.01)$ & $0.44(0.02)$ & $0.51(0.02)$ & $0.70(0.02)$ & $0.87(0.02)$ \\
\hline $5 / 13-5 / 19$ & 723 & $0.91(0.01)$ & $0.94(0.01)$ & $0.93(0.01)$ & $0.46(0.02)$ & $0.60(0.02)$ & $0.71(0.02)$ & $0.85(0.02)$ \\
\hline $5 / 20-5 / 26$ & 745 & $0.83(0.01)$ & $0.94(0.01)$ & $0.87(0.01)$ & $0.39(0.02)$ & $0.42(0.02)$ & $0.64(0.03)$ & $0.79(0.03)$ \\
\hline $5 / 27-6 / 8$ & 274 & $0.75(0.03)$ & $0.89(0.02)$ & $0.87(0.02)$ & $0.44(0.04)$ & $0.49(0.04)$ & $0.70(0.04)$ & $0.88(0.03)$ \\
\hline Pooled & 3002 & $0.90(0.01)$ & $0.93(0.00)$ & $0.91(0.01)$ & $0.42(0.01)$ & $0.50(0.01)$ & $0.68(0.01)$ & $0.84(0.01)$ \\
\hline \multicolumn{9}{|c|}{ Subyearling Chinook salmon } \\
\hline $6 / 18-6 / 24$ & 467 & $0.96(0.01)$ & $0.90(0.01)$ & $0.81(0.02)$ & $0.50(0.02)$ & $0.42(0.03)$ & $0.71(0.02)$ & $0.83(0.03)$ \\
\hline $6 / 25-7 / 1$ & 502 & $0.98(0.01)$ & $0.95(0.01)$ & $0.85(0.02)$ & $0.66(0.02)$ & $0.58(0.03)$ & $0.80(0.02)$ & $0.96(0.01)$ \\
\hline $7 / 2-7 / 8$ & 444 & $0.99(0.00)$ & $0.96(0.01)$ & $0.92(0.02)$ & $0.55(0.03)$ & $0.55(0.03)$ & $0.76(0.03)$ & $0.93(0.02)$ \\
\hline $7 / 9-7 / 15$ & 438 & $0.99(0.00)$ & $0.97(0.01)$ & $0.95(0.01)$ & $0.57(0.03)$ & $0.56(0.03)$ & $0.74(0.03)$ & $0.93(0.02)$ \\
\hline $7 / 16-7 / 23$ & 148 & $1.00(0.00)$ & $0.92(0.03)$ & $0.94(0.03)$ & $0.55(0.06)$ & $0.43(0.06)$ & $0.78(0.06)$ & $0.88(0.06)$ \\
\hline Pooled & 1999 & $0.98(0.00)$ & $0.94(0.01)$ & $0.87(0.01)$ & $0.57(0.01)$ & $0.52(0.01)$ & $0.76(0.01)$ & $0.91(0.01)$ \\
\hline
\end{tabular}


Table D.2. Cormack-Jolly-Seber survival estimates for acoustic-tagged yearling and subyearling Chinook salmon and steelhead from the forebay of Bonneville Dam (CR236.0) to each receiver array located downstream of Bonneville Dam in 2009 grouped by week of detection at the virtual release location (CR236.0). Standard errors are displayed in parentheses under each estimate.

\begin{tabular}{|c|c|c|c|c|c|c|c|}
\hline Virtual & CR192.0 & CR113.0 & CR086.2 & CR049.6 & CR037.3 & CR022.0 & CR008.3 \\
\hline release week & & & & & & & \\
\hline & \multicolumn{7}{|c|}{ Yearling Chinook Salmon } \\
\hline $4 / 30-5 / 6$ & $\begin{array}{c}0.977 \\
(0.007)\end{array}$ & $\begin{array}{c}0.958 \\
(0.009)\end{array}$ & $\begin{array}{c}0.956 \\
(0.010)\end{array}$ & $\begin{array}{c}0.929 \\
(0.017)\end{array}$ & $\begin{array}{c}0.929 \\
(0.020)\end{array}$ & $\begin{array}{c}0.843 \\
(0.019)\end{array}$ & $\begin{array}{c}0.804 \\
(0.024)\end{array}$ \\
\hline $5 / 7-5 / 13$ & $\begin{array}{c}0.960 \\
(0.007)\end{array}$ & $\begin{array}{c}0.944 \\
(0.008)\end{array}$ & $\begin{array}{c}0.944 \\
(0.008)\end{array}$ & $\begin{array}{c}0.924 \\
(0.013)\end{array}$ & $\begin{array}{c}0.885 \\
(0.013)\end{array}$ & $\begin{array}{c}0.842 \\
(0.014)\end{array}$ & $\begin{array}{c}0.806 \\
(0.017)\end{array}$ \\
\hline $5 / 14-5 / 20$ & $\begin{array}{c}0.944 \\
(0.009)\end{array}$ & $\begin{array}{c}0.924 \\
(0.010)\end{array}$ & $\begin{array}{c}0.921 \\
(0.010)\end{array}$ & $\begin{array}{c}0.875 \\
(0.015)\end{array}$ & $\begin{array}{c}0.825 \\
(0.016)\end{array}$ & $\begin{array}{c}0.778 \\
(0.016)\end{array}$ & $\begin{array}{c}0.738 \\
(0.018)\end{array}$ \\
\hline $5 / 21-5 / 27$ & $\begin{array}{c}0.959 \\
(0.013)\end{array}$ & $\begin{array}{c}0.943 \\
(0.008)\end{array}$ & $\begin{array}{c}0.945 \\
(0.009)\end{array}$ & $\begin{array}{c}0.939 \\
(0.012)\end{array}$ & $\begin{array}{c}0.903 \\
(0.014)\end{array}$ & $\begin{array}{c}0.912 \\
(0.016)\end{array}$ & $\begin{array}{c}0.791 \\
(0.022)\end{array}$ \\
\hline $5 / 28-6 / 2$ & $\begin{array}{c}0.975 \\
(0.013) \\
\end{array}$ & $\begin{array}{c}0.953 \\
(0.016) \\
\end{array}$ & $\begin{array}{c}0.950 \\
(0.017) \\
\end{array}$ & $\begin{array}{c}0.938 \\
(0.022) \\
\end{array}$ & $\begin{array}{c}0.907 \\
(0.027) \\
\end{array}$ & $\begin{array}{c}0.864 \\
(0.028) \\
\end{array}$ & $\begin{array}{c}0.846 \\
(0.032) \\
\end{array}$ \\
\hline Pooled & $\begin{array}{c}0.959 \\
(0.004)\end{array}$ & $\begin{array}{c}0.941 \\
(0.004)\end{array}$ & $\begin{array}{c}0.942 \\
(0.004)\end{array}$ & $\begin{array}{c}0.917 \\
(0.007)\end{array}$ & $\begin{array}{c}0.882 \\
(0.007)\end{array}$ & $\begin{array}{c}0.843 \\
(0.008)\end{array}$ & $\begin{array}{c}0.784 \\
(0.009)\end{array}$ \\
\hline \multicolumn{8}{|c|}{ Steelhead } \\
\hline $4 / 29-5 / 5$ & $\begin{array}{c}0.964 \\
(0.009)\end{array}$ & $\begin{array}{c}0.952 \\
(0.010)\end{array}$ & $\begin{array}{c}0.953 \\
(0.011)\end{array}$ & $\begin{array}{c}0.853 \\
(0.033)\end{array}$ & $\begin{array}{c}0.763 \\
(0.028)\end{array}$ & $\begin{array}{c}0.668 \\
(0.026)\end{array}$ & $\begin{array}{c}0.597 \\
(0.028)\end{array}$ \\
\hline $5 / 6-5 / 12$ & $\begin{array}{c}0.955 \\
(0.007)\end{array}$ & $\begin{array}{c}0.935 \\
(0.009)\end{array}$ & $\begin{array}{c}0.922 \\
(0.011)\end{array}$ & $\begin{array}{c}0.813 \\
(0.021)\end{array}$ & $\begin{array}{c}0.746 \\
(0.021)\end{array}$ & $\begin{array}{c}0.648 \\
(0.020)\end{array}$ & $\begin{array}{c}0.533 \\
(0.020)\end{array}$ \\
\hline $5 / 13-5 / 19$ & $\begin{array}{c}0.967 \\
(0.007)\end{array}$ & $\begin{array}{c}0.950 \\
(0.008)\end{array}$ & $\begin{array}{c}0.946 \\
(0.010)\end{array}$ & $\begin{array}{c}0.802 \\
(0.022)\end{array}$ & $\begin{array}{c}0.720 \\
(0.021)\end{array}$ & $\begin{array}{c}0.618 \\
(0.020)\end{array}$ & $\begin{array}{c}0.524 \\
(0.020)\end{array}$ \\
\hline $5 / 20-5 / 26$ & $\begin{array}{c}0.961 \\
(0.008)\end{array}$ & $\begin{array}{c}0.918 \\
(0.010)\end{array}$ & $\begin{array}{c}0.904 \\
(0.013)\end{array}$ & $\begin{array}{c}0.846 \\
(0.024)\end{array}$ & $\begin{array}{c}0.793 \\
(0.026)\end{array}$ & $\begin{array}{c}0.685 \\
(0.024)\end{array}$ & $\begin{array}{c}0.472 \\
(0.021)\end{array}$ \\
\hline $5 / 27-6 / 8$ & $\begin{array}{c}0.969 \\
(0.013)\end{array}$ & $\begin{array}{c}0.939 \\
(0.015)\end{array}$ & $\begin{array}{c}0.918 \\
(0.019)\end{array}$ & $\begin{array}{c}0.854 \\
(0.037)\end{array}$ & $\begin{array}{c}0.761 \\
(0.036)\end{array}$ & $\begin{array}{c}0.645 \\
(0.032)\end{array}$ & $\begin{array}{c}0.558 \\
(0.032)\end{array}$ \\
\hline Pooled & $\begin{array}{c}0.961 \\
(0.004) \\
\end{array}$ & $\begin{array}{c}0.937 \\
(0.005) \\
\end{array}$ & $\begin{array}{c}0.929 \\
(0.005) \\
\end{array}$ & $\begin{array}{c}0.828 \\
(0.012) \\
\end{array}$ & $\begin{array}{c}0.753 \\
(0.011) \\
\end{array}$ & $\begin{array}{c}0.651 \\
(0.010) \\
\end{array}$ & $\begin{array}{c}0.526 \\
(0.010) \\
\end{array}$ \\
\hline \multicolumn{8}{|c|}{ Subyearling Chinook salmon } \\
\hline $6 / 18-6 / 24$ & $\begin{array}{c}0.954 \\
(0.010)\end{array}$ & $\begin{array}{c}0.940 \\
(0.011)\end{array}$ & $\begin{array}{c}0.932 \\
(0.013)\end{array}$ & $\begin{array}{c}0.906 \\
(0.017)\end{array}$ & $\begin{array}{c}0.898 \\
(0.020)\end{array}$ & $\begin{array}{c}0.863 \\
(0.020)\end{array}$ & $\begin{array}{c}0.784 \\
(0.026)\end{array}$ \\
\hline $6 / 25-7 / 1$ & $\begin{array}{c}0.937 \\
(0.011)\end{array}$ & $\begin{array}{c}0.875 \\
(0.015)\end{array}$ & $\begin{array}{c}0.837 \\
(0.017)\end{array}$ & $\begin{array}{c}0.785 \\
(0.020)\end{array}$ & $\begin{array}{c}0.765 \\
(0.021)\end{array}$ & $\begin{array}{c}0.716 \\
(0.021)\end{array}$ & $\begin{array}{c}0.662 \\
(0.022)\end{array}$ \\
\hline $7 / 2-7 / 8$ & $\begin{array}{c}0.897 \\
(0.015)\end{array}$ & $\begin{array}{c}0.805 \\
(0.019)\end{array}$ & $\begin{array}{c}0.785 \\
(0.020)\end{array}$ & $\begin{array}{c}0.738 \\
(0.022)\end{array}$ & $\begin{array}{c}0.718 \\
(0.023)\end{array}$ & $\begin{array}{c}0.687 \\
(0.023)\end{array}$ & $\begin{array}{c}0.671 \\
(0.024)\end{array}$ \\
\hline $7 / 9-7 / 15$ & $\begin{array}{c}0.853 \\
(0.017)\end{array}$ & $\begin{array}{c}0.695 \\
(0.022)\end{array}$ & $\begin{array}{c}0.664 \\
(0.023)\end{array}$ & $\begin{array}{c}0.600 \\
(0.025)\end{array}$ & $\begin{array}{c}0.572 \\
(0.025)\end{array}$ & $\begin{array}{c}0.548 \\
(0.025)\end{array}$ & $\begin{array}{c}0.518 \\
(0.025)\end{array}$ \\
\hline $7 / 16-7 / 23$ & $\begin{array}{c}0.797 \\
(0.033) \\
\end{array}$ & $\begin{array}{c}0.578 \\
(0.041) \\
\end{array}$ & $\begin{array}{c}0.530 \\
(0.041) \\
\end{array}$ & $\begin{array}{c}0.489 \\
(0.044) \\
\end{array}$ & $\begin{array}{c}0.507 \\
(0.053) \\
\end{array}$ & $\begin{array}{c}0.431 \\
(0.043) \\
\end{array}$ & $\begin{array}{c}0.361 \\
(0.042) \\
\end{array}$ \\
\hline Pooled & $\begin{array}{c}0.904 \\
(0.007)\end{array}$ & $\begin{array}{c}0.813 \\
(0.009)\end{array}$ & $\begin{array}{c}0.788 \\
(0.009)\end{array}$ & $\begin{array}{c}0.740 \\
(0.011)\end{array}$ & $\begin{array}{c}0.723 \\
(0.011)\end{array}$ & $\begin{array}{c}0.685 \\
(0.011)\end{array}$ & $\begin{array}{c}0.637 \\
(0.012) \\
\end{array}$ \\
\hline
\end{tabular}


Table D.3. Cormack-Jolly-Seber reach survival estimates for acoustic-tagged yearling Chinook salmon (CH1), steelhead (STH), and subyearling Chinook salmon (CH0) in 2009.

\begin{tabular}{lccc}
\hline River reach & CH1 & STH & CH0 \\
\hline CR236.0 to CR192.0 & $0.959(0.004)$ & $0.961(0.004)$ & $0.904(0.007)$ \\
CR192.0 to CR113.0 & $0.982(0.003)$ & $0.975(0.003)$ & $0.900(0.007)$ \\
CR113.0 to CR086.2 & $1.000(0.001)$ & $0.991(0.004)$ & $0.968(0.005)$ \\
CR086.2 to CR049.6 & $0.974(0.006)$ & $0.893(0.012)$ & $0.939(0.008)$ \\
CR049.6 to CR022.0 & $0.916(0.009)$ & $0.774(0.017)$ & $0.906(0.012)$ \\
CR022.0 to CR008.3 & $0.931(0.010)$ & $0.808(0.014)$ & $0.927(0.011)$ \\
\hline
\end{tabular}

Table D.4. Survival per kilometer estimates for acoustic-tagged yearling Chinook salmon (CH1), steelhead (STH), and subyearling Chinook salmon (CH0) for each river reach in which survival was estimated in 2009.

\begin{tabular}{lccc}
\hline River reach & CH1 & STH & CH0 \\
\hline CR236.0 to CR192.0 & 0.9991 & 0.9991 & 0.9977 \\
CR192.0 to CR113.0 & 0.9992 & 0.9997 & 0.9987 \\
CR113.0 to CR086.2 & 0.9978 & 0.9997 & 0.9988 \\
CR086.2 to CR049.6 & 0.9976 & 0.9969 & 0.9983 \\
CR049.6 to CR022.0 & 0.9968 & 0.9908 & 0.9964 \\
CR022.0 to CR008.3 & 0.9824 & 0.9846 & 0.9945 \\
\hline
\end{tabular}





\section{Appendix E}

Likelihood Ratio Test Results for Comparison of Survival by Passage Route History at John Day and Bonneville Dams 



\section{Appendix E}

\section{Likelihood Ratio Test Results for Comparison of Survival by Passage Route History at John Day and Bonneville Dams}

Table E.1. Likelihood ratio test results for comparisons of survival from the Lady Island array (CR192.0) to the East Sand Island array (CR008.3) by route combination at John Day Dam and Bonneville Dam Powerhouse 2 for acoustic-tagged yearling Chinook salmon in 2009. Results are ordered by increasing $P$-value. Significant differences $(\alpha=0.05)$ are denoted with an asterisk $(*)$. For each comparison, the route combination with the higher estimated survival from CR192.0 to CR008.3 is listed first.

\begin{tabular}{|lcc|}
\hline Route comparison (JDA-BON) & $\chi^{2}$ & $P$-value \\
\hline TSW-JBS vs. TSW-CC & 3.657 & 0.0559 \\
\hline Spill-Turbine vs. TSW-CC & 3.382 & 0.0659 \\
\hline TSW-JBS vs. Spill-JBS & 3.358 & 0.0669 \\
\hline JBS-CC vs. TSW-CC & 3.314 & 0.0687 \\
\hline TSW-JBS vs. JBS-Turbine & 3.237 & 0.0720 \\
\hline TSW-JBS vs. Spill-CC & 3.188 & 0.0742 \\
\hline TSW-JBS vs. TSW-Turbine & 3.145 & 0.0762 \\
\hline JBS-CC vs. Spill-JBS & 3.069 & 0.0798 \\
\hline JBS-CC vs. JBS-Turbine & 2.977 & 0.0844 \\
\hline JBS-CC vs. TSW-Turbine & 2.891 & 0.0891 \\
\hline JBS-CC vs. Spill-CC & 2.879 & 0.0898 \\
\hline TSW-JBS vs. JBS-JBS & 2.858 & 0.0909 \\
\hline Spill-Turbine vs. Spill-JBS & 2.780 & 0.0954 \\
\hline Spill-Turbine vs. Spill-CC & 2.734 & 0.0983 \\
\hline JBS-CC vs. JBS-JBS & 2.674 & 0.1020 \\
\hline Spill-Turbine vs. JBS-Turbine & 2.572 & 0.1088 \\
\hline Spill-Turbine vs. TSW-Turbine & 2.458 & 0.1169 \\
\hline Spill-Turbine vs. JBS-JBS & 2.108 & 0.1466 \\
\hline TSW-JBS vs. Turbine-Turbine & 1.451 & 0.2284 \\
\hline JBS-CC vs. Turbine-Turbine & 1.307 & 0.2529 \\
\hline Spill-Turbine vs. Turbine-Turbine & 0.738 & 0.3904 \\
\hline Turbine-Turbine vs. JBS-JBS & 0.419 & 0.5174 \\
\hline TSW-JBS vs. Spill-Turbine & 0.344 & 0.5578 \\
\hline Turbine-Turbine JBS-Turbine & 0.322 & 0.5706 \\
\hline JBS-CC vs. Spill-Turbine & 0.277 & 0.5984 \\
\hline
\end{tabular}


Table E.1. (contd)

\begin{tabular}{lcc}
\hline Route comparison (JDA-BON) & $\chi^{2}$ & $P$-value \\
\hline Turbine-Turbine vs. TSW-Turbine & 0.259 & 0.6107 \\
\hline Turbine-Turbine vs. Spill-JBS & 0.256 & 0.6128 \\
\hline Turbine-Turbine vs. TSW-CC & 0.234 & 0.6288 \\
\hline Spill-CC vs. JBS-JBS & 0.218 & 0.6408 \\
\hline Turbine-Turbine vs. Spill-CC & 0.121 & 0.7272 \\
\hline Spill-CC vs. JBS-Turbine & 0.122 & 0.7273 \\
\hline TSW-CC vs. JBS-JBS & 0.166 & 0.7337 \\
\hline Spill-JBS vs. JBS-JBS & 0.077 & 0.7818 \\
\hline Spill-CC vs. TSW-Turbine & 0.069 & 0.7922 \\
\hline TSW-Turbine vs. JBS-JBS & 0.065 & 0.7994 \\
\hline Spill-CC vs. Spill-JBS & 0.063 & 0.8013 \\
\hline Spill-CC vs. TSW-CC & 0.041 & 0.8391 \\
\hline TSW-CC vs. JBS-Turbine & 0.037 & 0.8466 \\
\hline JBS-Turbine vs. JBS-JBS & 0.026 & 0.8722 \\
\hline Spill-JBS vs. JBS-Turbine & 0.015 & 0.9019 \\
\hline TSW-Turbine vs. JBS-Turbine & 0.010 & 0.9210 \\
\hline TSW-CC vs. TSW-Turbine & 0.009 & 0.9259 \\
\hline TSW-CC vs. Spill-JBS & 0.005 & 0.9429 \\
\hline TSW-JBS vs. JBS-CC & 0.001 & 0.9705 \\
\hline Spill-JBS vs. TSW-Turbine & 0.001 & 0.9817 \\
\hline
\end{tabular}


Table E.2. Likelihood ratio test results for comparisons of survival from the Lady Island array (CR192.0) to the East Sand Island array (CR008.3) by route combination at John Day Dam and Bonneville Dam Powerhouse 2 for acoustic-tagged steelhead in 2009. Results are ordered by increasing $P$-value. Significant differences $(\alpha=0.05)$ are denoted with an asterisk $(*)$. For each comparison, the route combination with the higher estimated survival from CR192.0 to CR008.3 is listed first.

\begin{tabular}{lcc}
\hline Route comparison (JDA-BON) & $\chi^{2}$ & $P$-value \\
\hline Spill-CC vs. JBS-CC & 10.843 & $0.0010^{*}$ \\
\hline TSW-Turbine vs. JBS-CC & 6.710 & $0.0096^{*}$ \\
\hline Spill-CC vs. TSW-CC & 5.643 & $0.0175^{*}$ \\
\hline Spill-CC vs. JBS-JBS & 4.260 & $0.0390^{*}$ \\
\hline TSW-Turbine vs. JBS-JBS & 3.384 & 0.0658 \\
\hline Spill-JBS vs. JBS-CC & 3.104 & 0.0781 \\
\hline TSW-CC vs. JBS-CC & 2.800 & 0.0943 \\
\hline Spill-JBS vs. JBS-JBS & 2.642 & 0.1041 \\
\hline JBS-Turbine vs. JBS-CC & 2.436 & 0.1186 \\
\hline Spill-CC vs. TSW-JBS & 2.167 & 0.1410 \\
\hline Spill-CC vs. Spill-Turbine & 2.135 & 0.1440 \\
\hline TSW-Turbine vs. TSW-CC & 2.085 & 0.1488 \\
\hline JBS-Turbine vs. JBS-JBS & 1.999 & 0.1574 \\
\hline TSW-JBS vs. JBS-CC & 1.829 & 0.1763 \\
\hline TSW-CC vs. JBS-JBS & 1.796 & 0.1802 \\
\hline Spill-CC vs. JBS-Turbine & 1.717 & 0.1901 \\
\hline TSW-JBS vs. JBS-JBS & 1.587 & 0.2078 \\
\hline Spill-Turbine vs. JBS-JBS & 1.041 & 0.3077 \\
\hline Spill-Turbine vs. JBS-CC & 1.020 & 0.3126 \\
\hline TSW-Turbine vs. Spill-Turbine & 0.927 & 0.3355 \\
\hline TSW-Turbine vs. TSW-JBS & 0.734 & 0.3917 \\
\hline Spill-JBS vs. TSW-CC & 0.642 & 0.4231 \\
\hline Spill-CC vs. TSW-Turbine & 0.561 & 0.4538 \\
\hline Spill-JBS vs. Spill-Turbine & 0.488 & 0.4848 \\
\hline TSW-Turbine vs. JBS-Turbine & 0.450 & 0.5022 \\
\hline Spill-CC vs. Spill-JBS & 0.332 & 0.5644 \\
\hline Spill-JBS vs. TSW-JBS & 0.318 & 0.5731 \\
\hline Spill-JBS vs. JBS-Turbine & 0.174 & 0.153 \\
\hline JBS-Turbine vs. TSW-CC & & 0.767 \\
\hline JBS-Turbine vs. Spill-Turbine & & \\
\hline
\end{tabular}


Table E.2. (contd)

\begin{tabular}{lcc}
\hline Route comparison (JDA-BON) & $\chi^{2}$ & $P$-value \\
\hline JBS-CC vs. JBS-JBS & 0.079 & 0.7780 \\
TSW-JBS vs. Spill-Turbine & 0.040 & 0.8409 \\
JBS-Turbine vs. TSW-JBS & 0.031 & 0.8594 \\
TSW-JBS vs. TSW-CC & 0.026 & 0.8726 \\
TSW-CC vs. Spill-Turbine & 0.011 & 0.9161 \\
TSW-Turbine vs. Spill-JBS & 0.007 & 0.9323 \\
\hline
\end{tabular}


Table E.3. Likelihood ratio test results for comparisons of survival from the Lady Island array (CR192.0) to the East Sand Island array (CR008.3) by route combination at John Day Dam and Bonneville Dam Powerhouse 2 for acoustic-tagged subyearling Chinook salmon in 2009. Results are ordered by increasing $P$-value. Significant differences $(\alpha=0.05)$ are denoted with an asterisk $(*)$. For each comparison, the route combination with the higher estimated survival from CR192.0 to CR008.3 is listed first.

\begin{tabular}{lcl}
\hline Route comparison (JDA-BON) & $\chi^{2}$ & $P$-value \\
\hline JBS-CC vs. Spill-JBS & 1.791 & 0.1808 \\
\hline Spill-CC vs. Spill-JBS & 1.369 & 0.2420 \\
\hline Spill-Turbine vs. Spill-JBS & 1.172 & 0.2791 \\
\hline JBS-CC vs. Turbine-Turbine & 0.781 & 0.3767 \\
\hline Turbine-CC vs. Spill-JBS & 0.557 & 0.4555 \\
\hline JBS-CC vs. Spill-CC & 0.389 & 0.5330 \\
\hline JBS-CC vs. Spill-Turbine & 0.384 & 0.5354 \\
\hline JBS-CC vs. Turbine-CC & 0.374 & 0.5407 \\
\hline JBS-CC vs. JBS-Turbine & 0.364 & 0.5462 \\
\hline Spill-CC vs. Turbine-Turbine & 0.313 & 0.5757 \\
\hline Spill-Turbine vs. Turbine-Turbine & 0.268 & 0.6050 \\
\hline JBS-Turbine vs. Spill-JBS & 0.248 & 0.6185 \\
\hline Turbine-CC vs. Turbine-Turbine & 0.118 & 0.7312 \\
\hline Turbine-Turbine vs. Spill-JBS & 0.100 & 0.7524 \\
\hline Spill-CC vs. JBS-Turbine & 0.064 & 0.7997 \\
\hline Spill-Turbine vs. JBS-Turbine & 0.052 & 0.8198 \\
\hline JBS-Turbine vs. Turbine-Turbine & 0.034 & 0.8534 \\
\hline Spill-CC vs. Turbine-CC & 0.027 & 0.8697 \\
\hline Spill-Turbine vs. Turbine-CC & 0.017 & 0.8970 \\
\hline Turbine-CC vs. JBS-Turbine & 0.013 & 0.9079 \\
\hline Spill-CC vs. Spill-Turbine & 0.002 & 0.9651 \\
\hline
\end{tabular}





\section{Appendix F}

\section{Burnham Test 2 and Test 3 Results}





\section{Appendix F}

\section{Burnham Test 2 and Test $3^{1}$ Results}

Table F.1. Burnham et al. (1987) Test 2 and Test $3 P$-values for detection histories used to estimate reach survival of acoustic-tagged yearling Chinook salmon from the Lady Island array (CR192.0) to the Cottonwood Island array (CR113.0) in 2009. Significant values $(\alpha=0.05)$ are denoted with an asterisk $(*)$.

\begin{tabular}{ccc}
\hline Virtual Release Date & Test $2 P$-value & Test $3 P$-value \\
\hline $4 / 30-5 / 6$ & 1.000 & 1.000 \\
$5 / 7-5 / 13$ & 0.681 & 1.000 \\
$5 / 14-5 / 20$ & 0.399 & 1.000 \\
$5 / 21-5 / 27$ & 1.000 & 1.000 \\
$5 / 28-6 / 2$ & $0.023^{*}$ & 1.000 \\
\hline
\end{tabular}

Table F.2. Burnham et al. (1987) Test 2 and Test 3 P-values for detection histories used to estimate reach survival of acoustic-tagged yearling Chinook salmon from the Cottonwood Island array (CR113.0) to the Oak Point array (CR086.2) in 2009. Significant values $(\alpha=0.05)$ are denoted with an asterisk (*).

\begin{tabular}{ccc}
\hline Virtual Release Date & Test $2 P$-value & Test $3 P$-value \\
\hline $4 / 30-5 / 6$ & 0.512 & 0.710 \\
$5 / 7-5 / 13$ & $0.014^{*}$ & 0.526 \\
$5 / 14-5 / 20$ & 0.095 & 0.821 \\
$5 / 21-5 / 27$ & 1.000 & 0.617 \\
$5 / 28-6 / 2$ & 0.680 & 1.000 \\
\hline
\end{tabular}

Table F.3. Burnham et al. (1987) Test 2 and Test 3 P-values for detection histories used to estimate reach survival of acoustic-tagged yearling Chinook salmon from the Oak Point array (CR086.2) to the Three Tree Point array (CR049.6) in 2009. Significant values $(\alpha=0.05)$ are denoted with an asterisk $(*)$.

\begin{tabular}{ccc}
\hline Virtual Release Date & Test $2 P$-value & Test $3 P$-value \\
\hline $4 / 30-5 / 6$ & 0.189 & 1.000 \\
$5 / 7-5 / 13$ & 0.651 & 0.118 \\
$5 / 14-5 / 20$ & 0.834 & 1.000 \\
$5 / 21-5 / 27$ & 0.437 & 0.781 \\
$5 / 28-6 / 2$ & 0.569 & 0.470 \\
\hline
\end{tabular}

\footnotetext{
${ }^{1}$ Burnham, K.P., Anderson, D.R., White, G.C., Brownie, C., and Pollock, K.H. 1987. Design and analysis methods for fish survival experiments based on release-recapture. American Fisheries Society Monograph 5.
} 
Table F.4. Burnham et al. (1987) Test 2 and Test 3 P-values for detection histories used to estimate reach survival of acoustic-tagged yearling Chinook salmon from the Three Tree Point array (CR049.6) to the Harrington Point array (CR037.3) in 2009. Significant values $(\alpha=0.05)$ are denoted with an asterisk $(*)$.

\begin{tabular}{ccc}
\hline Virtual Release Date & Test $2 P$-value & Test $3 P$-value \\
\hline $4 / 30-5 / 6$ & $0.046^{*}$ & 0.452 \\
$5 / 7-5 / 13$ & $<0.001^{*}$ & 0.385 \\
$5 / 14-5 / 20$ & 0.257 & 0.876 \\
$5 / 21-5 / 27$ & $0.014^{*}$ & 0.319 \\
$5 / 28-6 / 2$ & 0.199 & 1.000 \\
\hline
\end{tabular}

Table F.5. Burnham et al. (1987) Test 2 and Test 3 P-values for detection histories used to estimate reach survival of acoustic-tagged yearling Chinook salmon from the Harrington Point array (CR037.3) to the Astoria Bridge array (CR022.0) in 2009. Significant values $(\alpha=0.05)$ are denoted with an asterisk $(*)$.

\begin{tabular}{ccc}
\hline Virtual Release Date & Test $2 P$-value & Test $3 P$-value \\
\hline $4 / 30-5 / 6$ & 0.849 & 0.978 \\
$5 / 7-5 / 13$ & 0.345 & 0.201 \\
$5 / 14-5 / 20$ & $0.014^{*}$ & 0.380 \\
$5 / 21-5 / 27$ & 0.352 & 0.951 \\
$5 / 28-6 / 2$ & 0.105 & 0.073 \\
\hline
\end{tabular}

Table F.6. Burnham et al. (1987) Test 2 and Test 3 P-values for detection histories used to estimate reach survival of acoustic-tagged yearling Chinook salmon from the Astoria Bridge array (CR022.0) to the East Sand Island array (CR008.3) in 2009. Significant values $(\alpha=0.05)$ are denoted with an asterisk $(*)$.

\begin{tabular}{ccc}
\hline Virtual Release Date & Test $2 P$-value & Test $3 P$-value \\
\hline $4 / 30-5 / 6$ & 0.670 & 0.500 \\
$5 / 7-5 / 13$ & 0.593 & 0.073 \\
$5 / 14-5 / 20$ & 0.848 & 0.981 \\
$5 / 21-5 / 27$ & $0.033^{*}$ & 0.827 \\
$5 / 28-6 / 2$ & 0.105 & 0.073 \\
\hline
\end{tabular}


Table F.7. Burnham et al. (1987) Test 2 and Test 3 P-values for detection histories used to estimate reach survival of acoustic-tagged steelhead from the Lady Island array (CR192.0) to the Cottonwood Island array (CR113.0) in 2009. Significant values $(\alpha=0.05)$ are denoted with an asterisk (*).

\begin{tabular}{ccc}
\hline Virtual Release Date & Test $2 P$-value & Test $3 P$-value \\
\hline $4 / 29-5 / 5$ & 1.000 & 1.000 \\
$5 / 6-5 / 12$ & 1.000 & $0.025^{*}$ \\
$5 / 13-5 / 19$ & $<0.001^{*}$ & 0.289 \\
$5 / 20-5 / 26$ & 0.402 & 1.000 \\
$5 / 27-6 / 8$ & 0.816 & 1.000 \\
\hline
\end{tabular}

Table F.8. Burnham et al. (1987) Test 2 and Test 3 P-values for detection histories used to estimate reach survival of acoustic-tagged steelhead from the Cottonwood Island array (CR113.0) to the Oak Point array (CR086.2) in 2009. Significant values $(\alpha=0.05)$ are denoted with an asterisk $(*)$.

\begin{tabular}{ccc}
\hline Virtual Release Date & Test $2 P$-value & Test $3 P$-value \\
\hline $4 / 29-5 / 5$ & 0.632 & 0.375 \\
$5 / 6-5 / 12$ & 0.351 & 0.745 \\
$5 / 13-5 / 19$ & 0.716 & 0.133 \\
$5 / 20-5 / 26$ & 0.610 & 1.000 \\
$5 / 27-6 / 8$ & 1.000 & 0.239 \\
\hline
\end{tabular}

Table F.9. Burnham et al. (1987) Test 2 and Test 3 P-values for detection histories used to estimate reach survival of acoustic-tagged steelhead from the Oak Point array (CR086.2) to the Three Tree Point array (CR049.6) in 2009. Significant values $(\alpha=0.05)$ are denoted with an asterisk (*).

\begin{tabular}{ccc}
\hline Virtual Release Date & Test $2 P$-value & Test $3 P$-value \\
\hline $4 / 29-5 / 5$ & 0.138 & 1.000 \\
$5 / 6-5 / 12$ & 0.981 & 1.000 \\
$5 / 13-5 / 19$ & $0.006^{*}$ & 0.222 \\
$5 / 20-5 / 26$ & 0.808 & 0.496 \\
$5 / 27-6 / 8$ & 0.979 & 1.000 \\
\hline
\end{tabular}


Table F.10. Burnham et al. (1987) Test 2 and Test 3 P-values for detection histories used to estimate reach survival of acoustic-tagged steelhead from the Three Tree Point array (CR049.6) to the Harrington Point array (CR037.3) in 2009. Significant values $(\alpha=0.05)$ are denoted with an asterisk $(*)$.

\begin{tabular}{ccc}
\hline Virtual Release Date & Test $2 P$-value & Test $3 P$-value \\
\hline $4 / 29-5 / 5$ & 0.844 & 0.221 \\
$5 / 6-5 / 12$ & $0.028^{*}$ & 0.343 \\
$5 / 13-5 / 19$ & $0.002^{*}$ & 0.894 \\
$5 / 20-5 / 26$ & $0.002^{*}$ & 0.691 \\
$5 / 27-6 / 8$ & 0.613 & 0.800 \\
\hline
\end{tabular}

Table F.11. Burnham et al. (1987) Test 2 and Test 3 P-values for detection histories used to estimate reach survival of acoustic-tagged steelhead from the Harrington Point array (CR037.3) to the Astoria Bridge array (CR022.0) in 2009. Significant values $(\alpha=0.05)$ are denoted with an asterisk $(*)$.

\begin{tabular}{ccc}
\hline Virtual Release Date & Test $2 P$-value & Test $3 P$-value \\
\hline $4 / 29-5 / 5$ & 0.552 & 0.690 \\
$5 / 6-5 / 12$ & 0.416 & 0.175 \\
$5 / 13-5 / 19$ & 0.475 & 0.231 \\
$5 / 20-5 / 26$ & 0.491 & $0.001^{*}$ \\
$5 / 27-6 / 8$ & 0.082 & 0.148 \\
\hline
\end{tabular}

Table F.12. Burnham et al. (1987) Test 2 and Test 3 P-values for detection histories used to estimate reach survival of acoustic-tagged steelhead from the Astoria Bridge array (CR022.0) to the East Sand Island array (CR008.3) in 2009. Significant values $(\alpha=0.05)$ are denoted with an asterisk $(*)$.

\begin{tabular}{ccc}
\hline Virtual Release Date & Test $2 P$-value & Test 3 $P$-value \\
\hline $4 / 29-5 / 5$ & 0.409 & $0.011^{*}$ \\
$5 / 6-5 / 12$ & 0.844 & 0.298 \\
$5 / 13-5 / 19$ & 0.921 & 0.662 \\
$5 / 20-5 / 26$ & 0.113 & 0.429 \\
$5 / 27-6 / 8$ & 0.216 & 0.529 \\
\hline
\end{tabular}


Table F.13. Burnham et al. (1987) Test 2 and Test 3 P-values for detection histories used to estimate reach survival of acoustic-tagged subyearling Chinook salmon from the Lady Island array (CR192.0) to the Cottonwood Island array (CR113.0) in 2009. Significant values $(\alpha=0.05)$ are denoted with an asterisk $(*)$.

\begin{tabular}{ccc}
\hline Virtual Release Date & Test $2 P$-value & Test $3 P$-value \\
\hline $6 / 18-6 / 24$ & 0.217 & 0.224 \\
$6 / 25-7 / 1$ & 0.327 & 1.000 \\
$7 / 2-7 / 8$ & 1.000 & 0.063 \\
$7 / 9-7 / 15$ & 1.000 & 1.000 \\
$7 / 16-7 / 23$ & 1.000 & 1.000 \\
\hline
\end{tabular}

Table F.14. Burnham et al. (1987) Test 2 and Test 3 P-values for detection histories used to estimate reach survival of acoustic-tagged subyearling Chinook salmon from the Cottonwood Island array (CR113.0) to the Oak Point array (CR086.2) in 2009. Significant values $(\alpha=0.05)$ are denoted with an asterisk $(*)$.

\begin{tabular}{ccc}
\hline Virtual Release Date & Test $2 P$-value & Test $3 P$-value \\
\hline $6 / 18-6 / 24$ & 0.834 & 0.399 \\
$6 / 25-7 / 1$ & $0.019^{*}$ & 0.303 \\
$7 / 2-7 / 8$ & 1.000 & 0.271 \\
$7 / 9-7 / 15$ & 0.343 & 0.602 \\
$7 / 16-7 / 23$ & 1.000 & 0.510 \\
\hline
\end{tabular}

Table F.15. Burnham et al. (1987) Test 2 and Test 3 P-values for detection histories used to estimate reach survival of acoustic-tagged subyearling Chinook salmon from the Oak Point array (CR086.2) to the Three Tree Point array (CR049.6) in 2009. Significant values $(\alpha=0.05)$ are denoted with an asterisk $(*)$.

\begin{tabular}{ccc}
\hline Virtual Release Date & Test $2 P$-value & Test $3 P$-value \\
\hline $6 / 18-6 / 24$ & 0.930 & 1.000 \\
$6 / 25-7 / 1$ & 0.298 & 1.000 \\
$7 / 2-7 / 8$ & 0.911 & 1.000 \\
$7 / 9-7 / 15$ & 0.567 & 0.113 \\
$7 / 16-7 / 23$ & 1.000 & 1.000 \\
\hline
\end{tabular}


Table F.16. Burnham et al. (1987) Test 2 and Test 3 P-values for detection histories used to estimate reach survival of acoustic-tagged subyearling Chinook salmon from the Three Tree Point array (CR049.6) to the Harrington Point array (CR037.3) in 2009. Significant values $(\alpha=$ $0.05)$ are denoted with an asterisk $(*)$.

\begin{tabular}{ccc}
\hline Virtual Release Date & Test $2 P$-value & Test $3 P$-value \\
\hline $6 / 18-6 / 24$ & $<0.001^{*}$ & 1.000 \\
$6 / 25-7 / 1$ & $<0.001^{*}$ & $0.005^{*}$ \\
$7 / 2-7 / 8$ & $<0.001^{*}$ & 1.000 \\
$7 / 9-7 / 15$ & $<0.001^{*}$ & 0.195 \\
$7 / 16-7 / 23$ & $<0.001^{*}$ & 0.296 \\
\hline
\end{tabular}

Table F.17. Burnham et al. (1987) Test 2 and Test 3 P-values for detection histories used to estimate reach survival of acoustic-tagged subyearling Chinook salmon from the Harrington Point array (CR037.3) to the Astoria Bridge array (CR022.0) in 2009. Significant values $(\alpha=$ $0.05)$ are denoted with an asterisk $(*)$.

\begin{tabular}{ccc}
\hline Virtual Release Date & Test $2 P$-value & Test $3 P$-value \\
\hline $6 / 18-6 / 24$ & 0.796 & 0.360 \\
$6 / 25-7 / 1$ & $0.005^{*}$ & 0.888 \\
$7 / 2-7 / 8$ & 0.510 & 0.234 \\
$7 / 9-7 / 15$ & 0.696 & $0.046^{*}$ \\
$7 / 16-7 / 23$ & 0.745 & 0.732 \\
\hline
\end{tabular}

Table F.18. Burnham et al. (1987) Test 2 and Test 3 P-values for detection histories used to estimate reach survival of acoustic-tagged subyearling Chinook salmon from the Astoria Bridge array (CR022.0) to the East Sand Island array (CR008.3) in 2009. Significant values $(\alpha=$ $0.05)$ are denoted with an asterisk $(*)$.

\begin{tabular}{ccc}
\hline Virtual Release Date & Test $2 P$-value & Test $3 P$-value \\
\hline $6 / 18-6 / 24$ & 0.494 & 0.843 \\
$6 / 25-7 / 1$ & 0.627 & 0.785 \\
$7 / 2-7 / 8$ & 0.523 & 0.395 \\
$7 / 9-7 / 15$ & 0.296 & 0.219 \\
$7 / 16-7 / 23$ & 0.565 & 0.291 \\
\hline
\end{tabular}


Table F.19. Burnham et al. (1987) Test 2 and Test 3 P-values for detection histories used to estimate reach survival of acoustic-tagged yearling Chinook salmon from the Three Tree Point array (CR049.6) to the Astoria Bridge array (CR022.0) in 2009. Significant values $(\alpha=0.05)$ are denoted with an asterisk $(*)$.

\begin{tabular}{ccc}
\hline Virtual Release Date & Test $2 P$-value & Test $3 P$-value \\
\hline $4 / 30-5 / 6$ & 0.950 & 0.938 \\
$5 / 7-5 / 13$ & $0.023^{*}$ & 0.237 \\
$5 / 14-5 / 20$ & 0.154 & 0.979 \\
$5 / 21-5 / 27$ & 0.080 & 0.125 \\
$5 / 28-6 / 2$ & 0.946 & 0.633 \\
\hline
\end{tabular}

Table F.20. Burnham et al. (1987) Test 2 and Test 3 P-values for detection histories used to estimate reach survival of acoustic-tagged steelhead from the Three Tree Point array (CR049.6) to the Astoria Bridge array (CR022.0) in 2009. Significant values $(\alpha=0.05)$ are denoted with an asterisk $(*)$.

\begin{tabular}{ccc}
\hline Virtual Release Date & Test $2 P$-value & Test $3 P$-value \\
\hline $4 / 29-5 / 5$ & 0.817 & 0.616 \\
$5 / 6-5 / 12$ & 0.560 & 0.970 \\
$5 / 13-5 / 19$ & 0.472 & 0.254 \\
$5 / 20-5 / 26$ & 0.783 & 0.958 \\
$5 / 27-6 / 8$ & 0.453 & 0.088 \\
\hline
\end{tabular}

Table F.21. Burnham et al. (1987) Test 2 and Test 3 P-values for detection histories used to estimate reach survival of acoustic-tagged subyearling Chinook salmon from the Three Tree Point array (CR049.6) to the Astoria Bridge array (CR022.0) in 2009. Significant values $(\alpha=0.05)$ are denoted with an asterisk $(*)$.

\begin{tabular}{ccc}
\hline Virtual Release Date & Test $2 P$-value & Test $3 P$-value \\
\hline $6 / 18-6 / 24$ & 0.159 & 0.412 \\
$6 / 25-7 / 1$ & 0.537 & 0.828 \\
$7 / 2-7 / 8$ & $0.001^{*}$ & 0.370 \\
$7 / 9-7 / 15$ & 0.353 & 0.585 \\
$7 / 16-7 / 23$ & 1.000 & 0.289 \\
\hline
\end{tabular}



Appendix G

Locations of CR022.0, CR008.3, and CR002.8 Receivers from Reference Points for Cross-Channel Distribution Analyses 



\section{Appendix G}

\section{Locations of Astoria Bridge (CR022.0), East Sand Island (CR008.3), and Columbia River Bar (CR002.8) Receivers from Reference Points for Cross-Channel Distribution Analyses}

Table G.1. Location of the South Jetty reference point and location and distance in kilometers of each Columbia River Bar (CR002.8) receiver from the South Jetty reference point.

\begin{tabular}{|c|c|c|c|}
\hline & \multicolumn{3}{|c|}{ Receiver Location } \\
\hline & Latitude & Longitude & Distance from South Jetty $(\mathrm{km})$ \\
\hline South Jetty Reference Point & 46.2333 & -124.0616 & -- \\
\hline CR002.8_01 & 46.2711 & -124.0706 & 4.25 \\
\hline CR002.8_02 & 46.2701 & -124.0698 & 4.13 \\
\hline CR002.8_03 & 46.2690 & -124.0690 & 4.01 \\
\hline CR002.8_04 & 46.2681 & -124.0682 & 3.89 \\
\hline CR002.8_05 & 46.2670 & -124.0674 & 3.77 \\
\hline CR002.8_06 & 46.2660 & -124.0667 & 3.65 \\
\hline CR002.8_07 & 46.2649 & -124.0658 & 3.52 \\
\hline CR002.8_08 & 46.2639 & -124.0650 & 3.41 \\
\hline CR002.8_09 & 46.2629 & -124.0642 & 3.29 \\
\hline CR002.8_10 & 46.2620 & -124.0634 & 3.18 \\
\hline CR002.8_11 & 46.2609 & -124.0627 & 3.07 \\
\hline CR002.8_12 & 46.2595 & -124.0622 & 2.90 \\
\hline CR002.8_13 & 46.2579 & -124.0618 & 2.73 \\
\hline CR002.8_14 & 46.2564 & -124.0614 & 2.56 \\
\hline CR002.8_15 & 46.2549 & -124.0610 & 2.40 \\
\hline CR002.8_16 & 46.2534 & -124.0605 & 2.23 \\
\hline CR002.8_17 & 46.2524 & -124.0603 & 2.12 \\
\hline CR002.8_18 & 46.2513 & -124.0601 & 2.00 \\
\hline CR002.8_19 & 46.2504 & -124.0600 & 1.90 \\
\hline CR002.8_20 & 46.2494 & -124.0598 & 1.79 \\
\hline CR002.8_21 & 46.2484 & -124.0598 & 1.68 \\
\hline CR002.8_22 & 46.2474 & -124.0597 & 1.57 \\
\hline CR002.8_23 & 46.2464 & -124.0597 & 1.46 \\
\hline CR002.8_24 & 46.2454 & -124.0597 & 1.35 \\
\hline CR002.8_25 & 46.2444 & -124.0596 & 1.24 \\
\hline CR002.8_26 & 46.2429 & -124.0602 & 1.07 \\
\hline CR002.8_27 & 46.2415 & -124.0609 & 0.90 \\
\hline CR002.8_28 & 46.2400 & -124.0615 & 0.74 \\
\hline CR002.8_29 & 46.2385 & -124.0623 & 0.58 \\
\hline CR002.8_30 & 46.2371 & -124.0629 & 0.42 \\
\hline CR002.8_31 & 46.2356 & -124.0636 & 0.29 \\
\hline
\end{tabular}


Table G.2.Location of the Clatsop Spit reference point and location and distance in kilometers of each East Sand Island (CR008.3) receiver from the Clatsop Spit reference point.

\begin{tabular}{lccc}
\hline & \multicolumn{3}{c}{ Receiver Location } \\
\cline { 2 - 4 } \multicolumn{1}{c}{ Receiver } & Latitude & Longitude & $\begin{array}{c}\text { Distance } \\
\text { from Clatsop Spit } \\
(\mathrm{km})\end{array}$ \\
\hline Clatsop Spit Reference Point & 46.2354 & -123.9993 & -- \\
CR008.3_24 & 46.2352 & -123.9972 & 0.16 \\
\hline CR008.3_23 & 46.2364 & -123.9962 & 0.27 \\
CR008.3_22 & 46.2376 & -123.9951 & 0.41 \\
\hline CR008.3_19 & 46.2404 & -123.9920 & 0.79 \\
CR008.3_18 & 46.2412 & -123.9937 & 0.79 \\
CR008.3_17 & 46.2426 & -123.9941 & 0.90 \\
CR008.3_16 & 46.2439 & -123.9946 & 1.01 \\
CR008.3_15 & 46.2452 & -123.9949 & 1.15 \\
\hline CR008.3_14 & 46.2466 & -123.9953 & 1.28 \\
CR008.3_13 & 46.2479 & -123.9957 & 1.43 \\
\hline CR008.3_12 & 46.2492 & -123.9962 & 1.56 \\
CR008.3_11 & 46.2505 & -123.9966 & 1.70 \\
CR008.3_10 & 46.2520 & -123.9971 & 1.86 \\
CR008.309 & 46.2532 & -123.9975 & 1.99 \\
CR008.3_08 & 46.2546 & -123.9978 & 2.14 \\
\hline CR008.3_07 & 46.2560 & -123.9983 & 2.29 \\
\hline CR008.3_06 & 46.2572 & -123.9986 & 2.43 \\
\hline CR008.3_05 & 46.2586 & -123.9991 & 2.59 \\
CR008.3_04 & 46.2600 & -123.9995 & 2.74 \\
CR008.3_03 & 46.2614 & -123.9999 & 2.89 \\
\hline CR008.3_02 & 46.2626 & -124.0005 & 3.03 \\
CR008.3_01 & 46.2643 & -124.0009 & 3.22 \\
\hline & & & \\
\hline
\end{tabular}


Table G.3.Location of the Astoria reference point and location and distance in kilometers of each Astoria Bridge (CR022.0) receiver from the Astoria reference point.

\begin{tabular}{lccc}
\hline & \multicolumn{3}{c}{ Receiver Location } \\
\cline { 2 - 4 } \multicolumn{1}{c}{ Receiver } & Latitude & Longitude & $\begin{array}{c}\text { Distance from Clatsop Spit } \\
(\mathrm{km})\end{array}$ \\
\hline Astoria Reference Point & 46.1904 & -123.84930 & -- \\
CR022.0_01 & 46.24012 & -123.87228 & 5.80 \\
CR022.0_02 & 46.23879 & -123.87162 & 5.64 \\
CR022.0_03 & 46.23755 & -123.87145 & 5.51 \\
CR022.0_04 & 46.23651 & -123.87073 & 5.38 \\
CR022.0_05 & 46.23533 & -123.87034 & 5.25 \\
CR022.0_06 & 46.23433 & -123.86976 & 5.13 \\
CR022.0_07 & 46.23313 & -123.86905 & 4.98 \\
CR022.0_08 & 46.23187 & -123.86879 & 4.85 \\
CR022.0_09 & 46.23087 & -123.86838 & 4.73 \\
CR022.0_10 & 46.22988 & -123.86777 & 4.61 \\
CR022.0_11 & 46.21728 & -123.86141 & 3.13 \\
CR022.0_12 & 46.19805 & -123.85169 & 0.87 \\
CR022.0_13 & 46.19706 & -123.85100 & 0.75 \\
CR022.0_14 & 46.19613 & -123.85049 & 0.64 \\
CR022.0_15 & 46.19542 & -123.85004 & 0.56 \\
CR022.0_16 & 46.19249 & -123.84847 & 0.24 \\
CR022.0_17 & 46.19175 & -123.85214 & 0.26 \\
\hline
\end{tabular}



Appendix $\mathrm{H}$

Autonomous Receiver Data Gap Chart 



\section{Appendix $\mathrm{H}$}

\section{Autonomous Receiver Data Gap Chart}

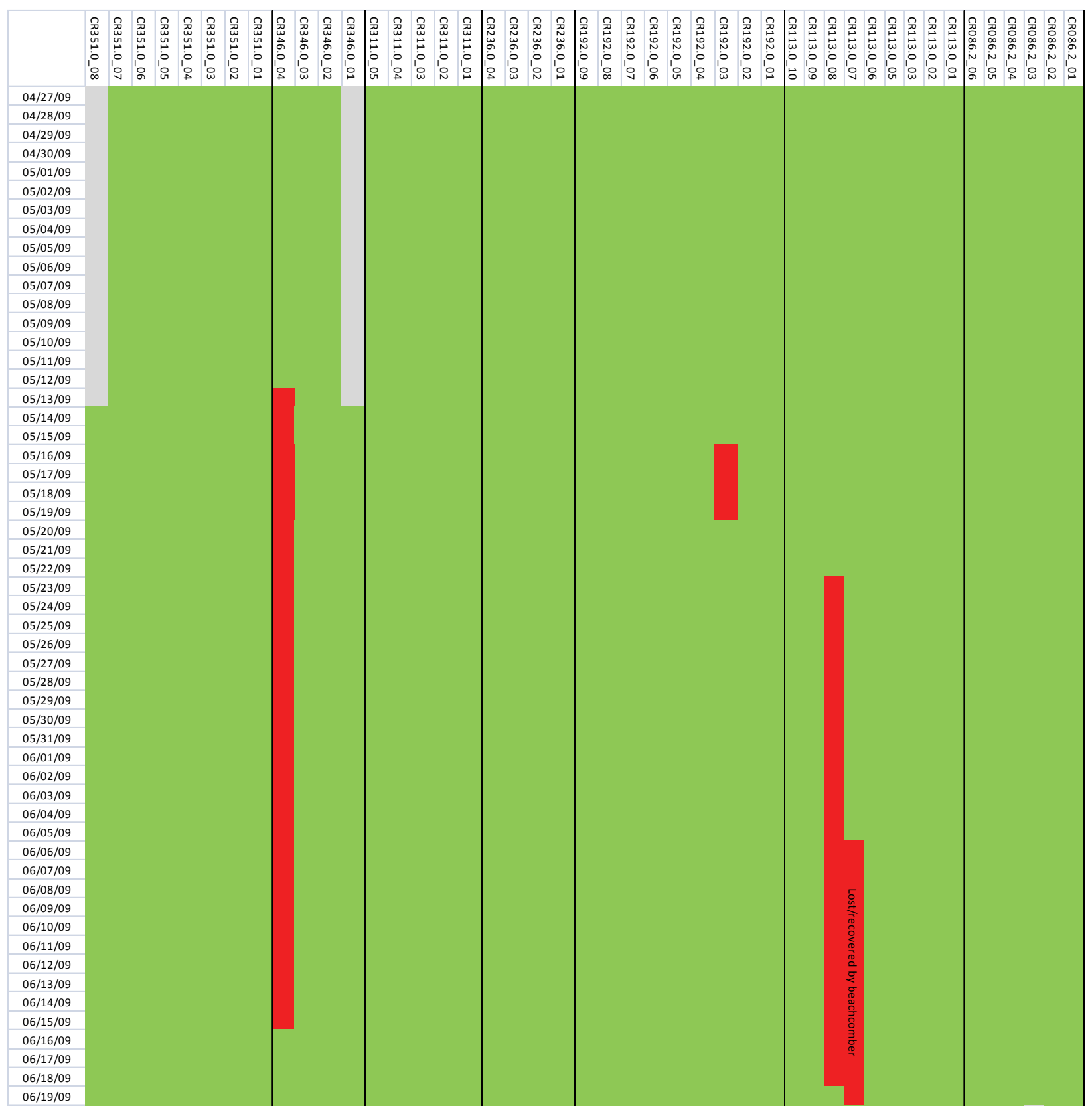

Figure H.1. Autonomous receiver data availability for arrays between rkm 351 and 86.2 between 27 April and 19 June, 2009. Green indicates data available, red indicates data not available, yellow indicates corrupted (binary) data, and gray indicates questionable data quality, typically due to low power or hydrophone damage. This project used data from arrays at rkm 192 through rkm 2.8. 


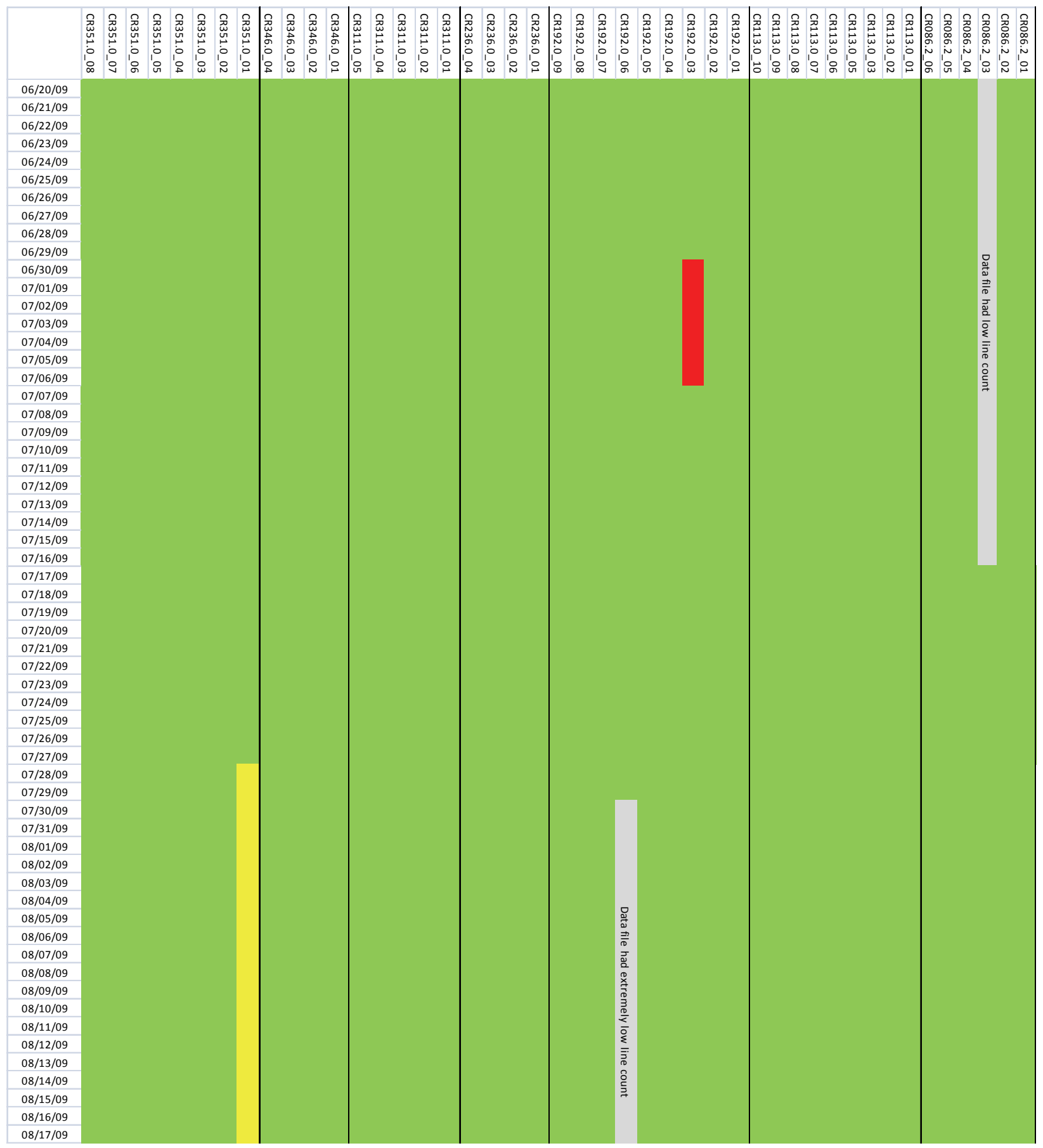

Figure H.2. Autonomous receiver data availability for arrays between $\mathrm{rkm} 351$ and rkm 86.2 between 20 June and 17 August, 2009. Green indicates data available, red indicates data not available, yellow indicates corrupted (binary) data, and gray indicates questionable data quality, typically due to low power or hydrophone damage. This project used data from arrays at rkm 192 through rkm 2.8 . 


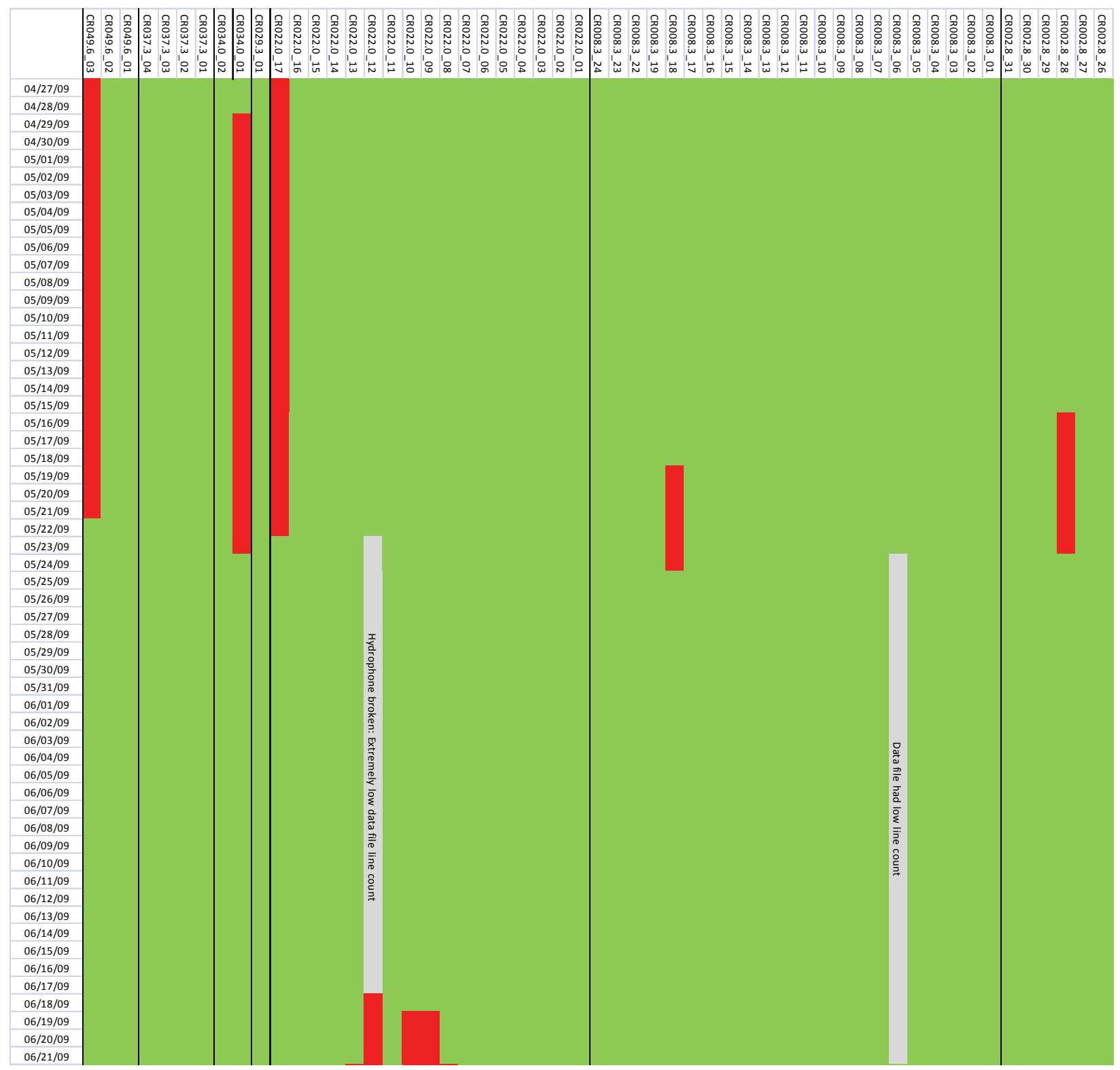

Figure H.3.Autonomous receiver data availability for arrays between rkm 49.6 and rkm 2.8 between 27 April and 21 June, 2009. Green indicates data available, red indicates data not available, yellow indicates corrupted (binary) data, and gray indicates questionable data quality, typically due to low power or hydrophone damage. 


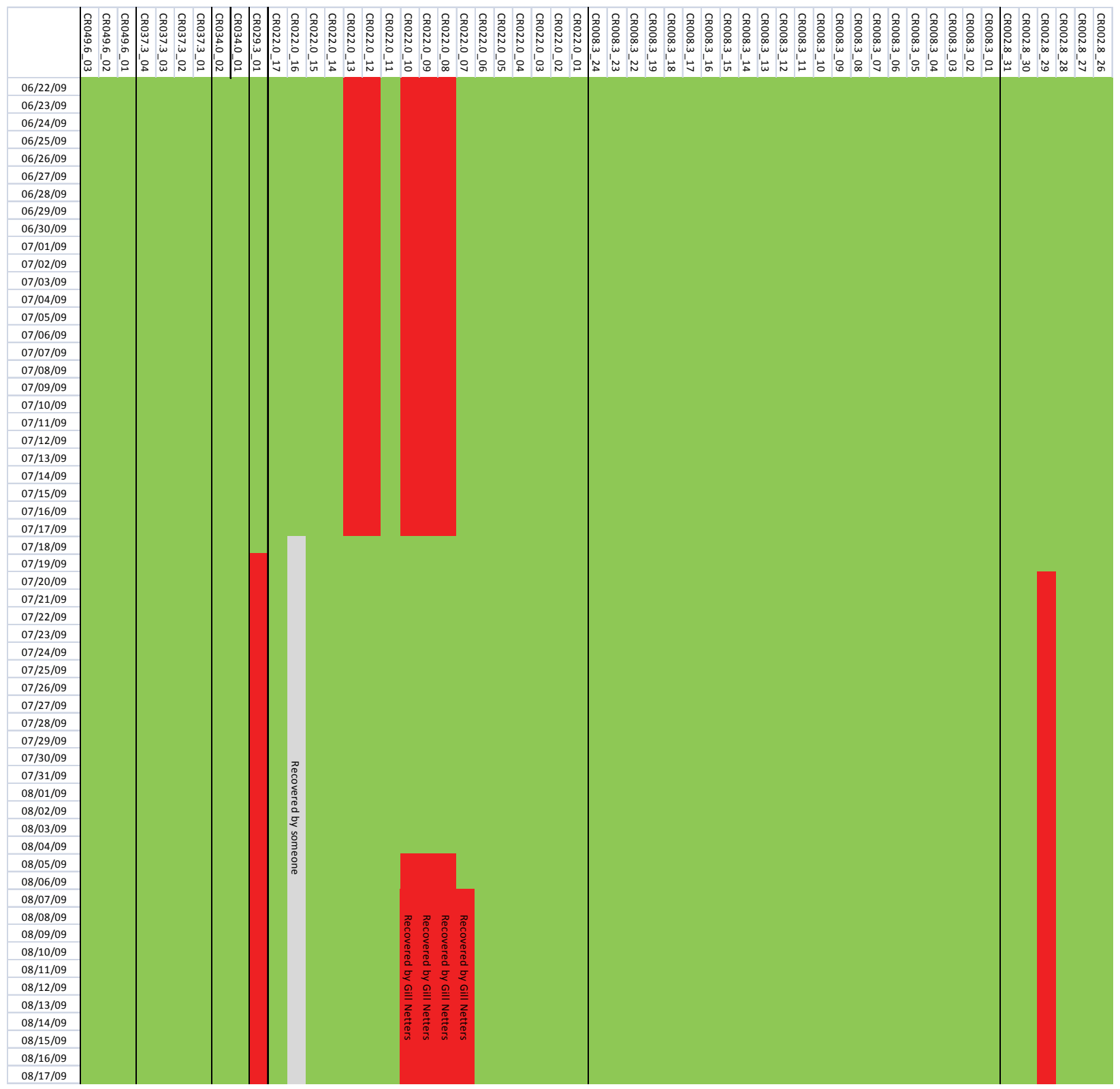

Figure H.4. Autonomous receiver data availability for arrays between rkm 49.6 and rkm 2.8 between 22 June and 17 August, 2009. Green indicates data available, red indicates data not available, yellow indicates corrupted (binary) data, and gray indicates questionable data quality, typically due to low power or hydrophone damage. 



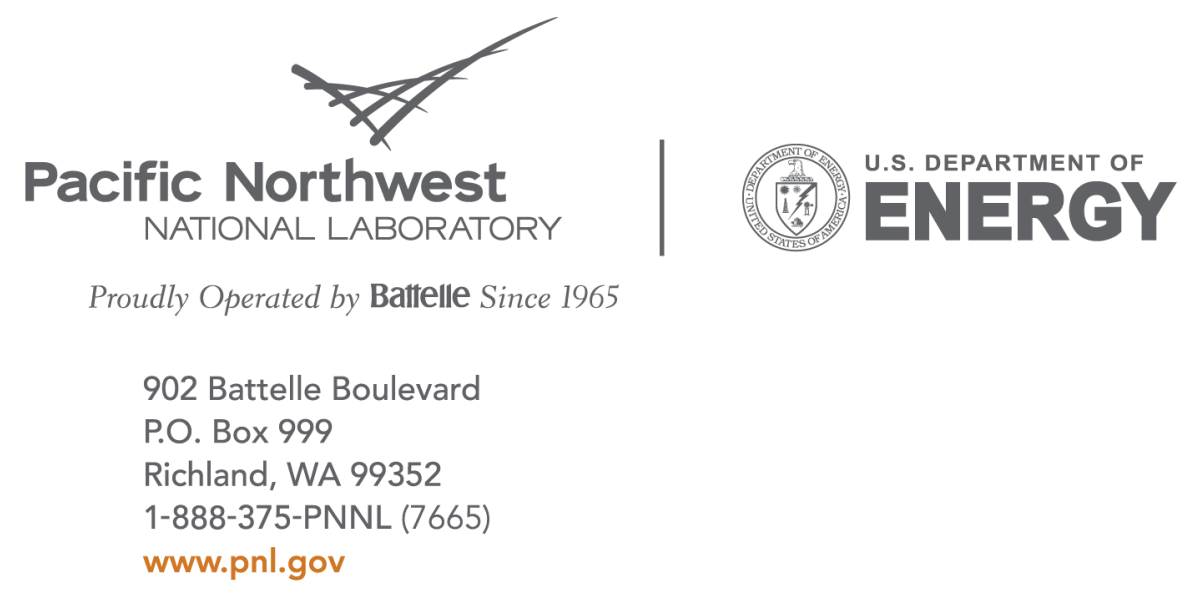

